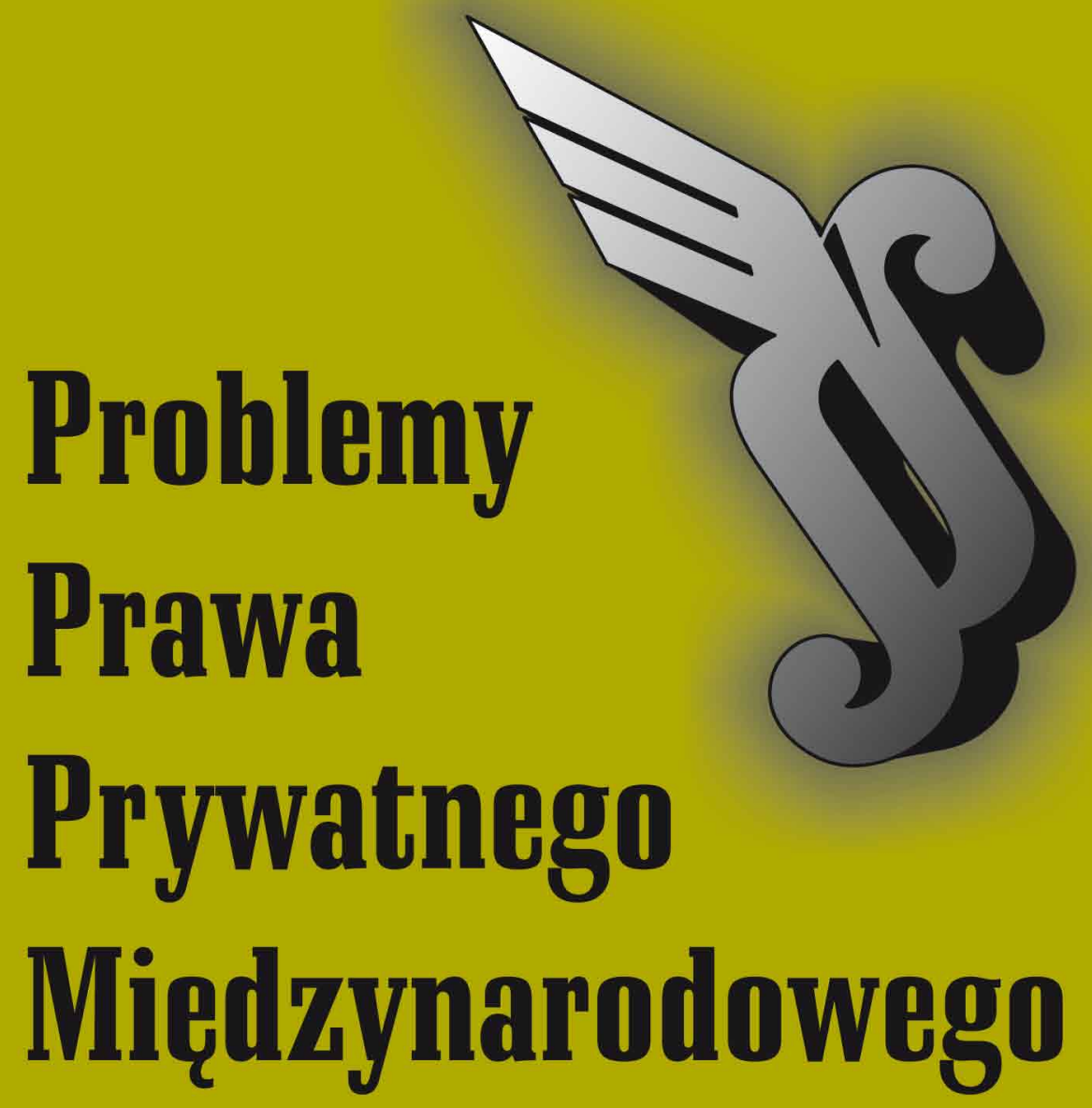

\title{
TOM 23
}




\section{Problemy Prawa}

Prywatnego Międzynarodowego

\section{Tom 23}

pod redakcja

Maksymiliana Pazdana 


\section{Zespół Redakcyjny}

Maksymilian Pazdan (redaktor naukowy, Uniwersytet Śląski w Katowicach, Akademia Leona Koźmińskiego)

Katarzyna Grzybczyk (redaktor tematyczny, Uniwersytet Śląski w Katowicach)

Witold Kurowski (sekretarz Redakcji, Uniwersytet Śląski w Katowicach)

Katarzyna Sznajder-Peroń (sekretarz Redakcji, Uniwersytet Śląski w Katowicach)

Maciej Zachariasiewicz (sekretarz Redakcji, Akademia Leona Koźmińskiego)

\section{Rada Naukowa}

Christian von Bar (Universität Osnabrück), Paul Lagarde (Université Paris I), Rett R. Ludwikowski (The Catholic University of America), Heinz-Peter Mansel (Universität zu Köln), Dieter Martiny (Europa-Universität Viadrina), Andrzej Maczyński (Uniwersytet Jagielloński), Paul Meijknecht (Universiteit Utrecht), Cezary Mik (Uniwersytet Kardynała Stefana Wyszyńskiego), Jerzy Poczobut (Uniwersytet Warszawski), Jerzy Rajski (Uniwersytet Warszawski), Andrzej Szumański (Uniwersytet Jagielloński), Luboš Tichý (Univerzita Karlova)

\section{Zespół Recenzentów}

László Burián (Pázmány Péter Katolikus Egyetem, Budapeszt), Jan Ciszewski (Ministerstwo Sprawiedliwości), Maria Dragun-Gertner (Uniwersytet Mikołaja Kopernika w Toruniu), Przemysław Drapała (Akademia Leona Koźmińskiego), Bogusława Gnela (Uniwersytet Ekonomiczny w Krakowie), Bettina Heiderhoff (Universität Münster), Agnieszka Jańczuk-Gorywoda (Universiteit van Tilburg), Joanna Kruczalak-Jankowska (Uniwersytet Gdański), Dorota Leczykiewicz (University of Oxford), Piotr Machnikowski (Uniwersytet Wrocławski), Maciej Mataczyński (Uniwersytet im. Adama Mickiewicza w Poznaniu), Piotr Mostowik (Uniwersytet Jagielloński), Maxi Scherer (University of London), Maciej Szpunar (Uniwersytet Śląski w Katowicach), Andrzej Tynel (Baker \& McKenzie), Karol Weitz (Uniwersytet Warszawski), Andrzej W. Wiśniewski (Uniwersytet Warszawski), Arkadiusz Wowerka (Uniwersytet Gdański), Arkadiusz Wudarski (Europa-Universität Viadrina), Fryderyk Zoll (Uniwersytet Jagielloński, Universität Osnabrück)

\section{Adres Redakcji}

„Problemy Prawa Prywatnego Międzynarodowego"

Wydział Prawa i Administracji Uniwersytetu Śląskiego w Katowicach

40-007 Katowice, ul. Bankowa 11b

tel. (032) 35918 03; e-mail: witold.kurowski@us.edu.pl 


\section{Spis treści}

Zdeněk Kučera (1928-2017). Wspomnienie (Witold Kurowski) . . 7

Nachruf auf Professor Zdeněk Kučera (Luboš Tichý) . . . . . . . 9

\section{Studia}

Wojciech Dybka: Trademark trolling jako przykład zgłoszenia znaku towarowego w złej wierze

Paweł Jędrysiak: Odpowiedzialność za naruszenie dóbr osobistych osób nieletnich z wykorzystaniem portali społecznościowych w ramach parental trollingu

Paweł Jasiński: Środki przeciwdziałania nadużyciu idei ochrony patentowej przez tak zwanych trolli patentowych w prawie unijnym

Łukasz Maryniak: Konstrukcje prawne chroniace przed copyright trollingiem

Aleksandra Drapała: Parental trolling w świetle uregulowań polskiej ustawy karnej

Karolina Rybak: Rodzina trolli — porównanie konstrukcji copyright i patent trollingu

Katarzyna Kluczka: Patent trolling w Wielkiej Brytanii

\section{Materiały}

Jubileusz 50-lecia pracy naukowej Profesora dr. hab. Andrzeja Mączyńskiego. Sprawozdanie z konferencji naukowej nt. Prawo prywatne międzynarodowe wobec wyzwań XXI wieku, Kraków, 14 maja 2018 roku (w imieniu organizatorów Jubileuszu i sesji Sybilla Stanisławska-Kloc) 


\section{Contents}

Zdeněk Kučera (1928-2017). In memorial (Witold Kurowski) . . . 7

Tribute to Professor Zdeněk Kučera (Luboš Tichý) . . . . . . 9

\section{Studies}

Wojciech Dybka: Trademark trolling as an example of trademark's application made in bad faith

Paweł Jędrysiak: Responsibility for violation of personal rights of minors in social networks

Paweł Jasiński: Protection measures against the abuse of the idea of patent protection by the so-called patent trolls in EU law

Łukasz Maryniak: Legal solutions protecting against copyright trolling

Aleksandra Drapała: Parental trolling in light of the provisions of the Polish Penal Code

Karolina Rybak: The family of trolls - comparison between the constructions of copyright and patent trolling

\section{Materials}

50th Anniversary of Professor Andrzej Mączyński's scientific work. Report on the scientific conference Private international law in the face of the challenges of the 21st century, Kraków, 14 May 2018 (prepared by Sybilla Stanistawska-Kloc) 


\section{Table des matières}

Zdeněk Kučera (1928-2017). In memoriam (Witold Kurowski) . . 7

Nachruf auf Professor Zdeněk Kučera (Luboš Tichý) _ . . . . . . 9

\section{Etudes}

Wojciech Dybka: Le trademark trolling en tant qu'exemple de dépôt de la demande d'enregistrement de la marque effectué de mauvaise foi

Paweł Jędrysiak: La responsabilité pour l'atteinte aux droits de la personnalité des mineurs au moyen des réseaux sociaux dans le cadre du parental trolling

Paweł Jasiński: Les mesures contre l'abus de l’idée de protection par brevet par des soi-disant trolls dans le droit de l'Union

Łukasz Maryniak: Constructions juridiques protégeant contre le copyright trolling

Aleksandra Drapała: Le parental trolling à la lumière des dispositions de la loi pénale polonaise

Karolina Rybak: La famille des trolls — la comparaison des constructions de copyright et de patent trolling

Katarzyna Kluczka: Le patent trolling en Grande-Bretagne . . . . . 107

Joanna Radziszewska: Le copyright trolling et le droit de citation

\section{Materiaux}

Le jubilé de 50 ans d'activité scientifique du Professeur Andrzej Mączyński. Compte rendu de la conférence scientifique intitulée Droit international privé face aux défis du XXIe siécle, Cracovie, le 14 mai 2018 (élaboré par Sybilla Stanisławska-Kloc) 


\section{Содержание}

Zdeněk Kučera (1928-2017). Воспоминание (Витольд Куровски) . . 7

Nachruf auf Professor Zdeněk Kučera (Любош Tuхи) . . . . . . 9

\section{Исследования}

Войчех Дыбка: Троллинг товарных знаков как пример недобросовестной подачи заявки на регистрацию товарного знака

Павел Ендрисяк: Ответственность за нарушение личных прав несовершеннолетних с использованием социальных сетей в рамках родительского троллинга

Павел Ясински: Меры по противодействию злоупотреблению идеей патентной защиты со стороны так называемых патентных троллей в законодательстве ЕС

Лукаш Марыняк: Юридические конструкции, защищающие от авторского троллинга

Александра Драпала: Родительский троллинг в свете положений польского уголовного закона

Каролина Рыбак: Семейство троллей — сравнение конструкций авторского и патентного троллинга

Катажина Ключка: Патентный троллинг в Великобритании . 107

Йоанна Радзишевска: Авторский троллинг и право цитирования 123

\section{Материалы}

50-летие научной работы профессора д-р хаб. Анджея Мончинского. Отчет по научной конференции Международное частное право перед лицол вызовов XXI века, Краков, 14 мая 2018 года (подготовила Сибилла Станиславска-Клои) 


\section{Zdeněk Kučera (1928—2017) Wspomnienie}

W pierwszych dniach 2018 r. dotarła do nas wiadomość o śmieci Profesora Zdenka Kučery, członka Rady Naukowej „Problemów Prawa Prywatnego Międzynarodowego”. Mimo że do jej grona formalnie dołączył w 2012 r., z naszym czasopismem związany był już o wiele wcześniej, mianowicie jeszcze wtedy, gdy ukazywało się pod nazwą „Problemy Prawne Handlu Zagranicznego".

Profesor Zdeněk Kučera był jednym z najwybitniejszych kolizjonistów czechosłowackich, a później czeskich, autorem ponad 120 prac poświęconych prawu prywatnemu międzynarodowemu. Jednak jednym z najważniejszych Jego dokonań było opublikowanie cenionego przez studentów i praktyków podręcznika, jak również opracowanie projektu czeskiej ustawy kolizyjnej z 2012 r., która zastąpiła czechosłowacką regulację z początku lat sześćdziesiątych ubiegłego stulecia.

Dnia 27 grudnia 2017 r. odszedł od nas wybitny Prawnik i prawdziwy Przyjaciel... 



\section{Nachruf auf Professor Zdeněk Kučera}

Am 27. Dezember 2017 ist Professor Zdeněk Kučera verstorben, der bekannteste tschechoslowakische und tschechische Kenner des IPR, der Reformator dieses Gebietes, ein langjähriger Lehrer in diesem Bereich an allen Rechtsfakultäten in der Tschechischen Republik. Er hinterlässt einen erheblichen intellektuellen Nachlass. Fast bis zu seinem Tode war er aktiv.

Zdeněk Kučera wurde in Prag am 17. Juni 1928 in einer bürgerlichen Familie geboren. Nach dem Abschluss des Gymnasiums studierte er in den Jahren 1947-1951 an der juristischen Fakultät der Karlsuniversität, wo auch er im Jahre 1951 zum Doktor juris promoviert wurde. Er wirkte dann als Anwaltsanwärter und von 1953 bis 1955 als Anwalt. In den Jahren 1955-1959 war er Beamter der Gesetzgebungsabteilung des Justizministeriums und 1959-1964 Assessor in der juristischen Abteilung des Außenhandelsunternehmens Centrotex in Prag. Von 1964 bis 1966 war er in der juristischen Abteilung des Ministeriums für Außenhandel tätig. Seit dem 1. Januar 1967 begann er seine akademische Karriere. Er wurde wissenschaftlicher Assistent am Lehrstuhl für internationales Recht der juristischen Fakultät der Karlsuniversität.

So ordnete er sich so in die Reihe einiger damaliger Persönlichkeiten dieses Lehrstuhles ein, wo Professor Rudolf Bystrický die führende Persönlichkeit im Bereich des IPR darstellte. Andere bedeutende Persönlichkeiten waren Michael Milde und ein freier Mitarbeiter, ein Beamter des damaligen Ministeriums für Außenhandel und nachher ein Mitarbeiter von UNCITRAL in Wien, Ludvík Kopáč. IPR stand damals unter dem Einfluss von zwei Faktoren: ähnlich wie an sowjetischen, aber auch an italienischen Universitäten war IPR eigentlich Teil vom Völkerrecht, und gleichzeitig stand es unter dem Einfluss der damaligen Auffassung des Außenhandelsmonopols, sodass ein Teil von IPR auch das Recht des 
Außenhandels war. Übrigens blieb dieser Anhängsel aus mir unbekannten Gründen bis zum heutigen Tag Teil des IPR.

Noch in den 60er Jahren hatte Kučera seine Dissertation „Kaufvertrag im Import" eingereicht und erlangte damit den Titel Kandidat der Wissenschaften, der dem heutigen Titel PhD entspricht. Nachher hat er sich mit der Arbeit über Bürgschaften als eine Art von Kreditsicherheiten habilitiert. Das Ende des Prager Frühlings wirkte sich auch an der juristischen Fakultät aus: die so genannte „Normalisierung“, d.h. die Ära von Gustáv Husák, belastete sie schwerwiegend. Die Besetzung des Lehrkörpers veränderte sich, und es litt vor allem die Moral. Bystrický und Milde sind emigriert. Die Führung des Lehrstuhls wurde in die Hände von Kollaborateuren oder direkt Vertretern des Regimes gelegt. Kučera konnte bleiben, auch wenn er einen Preis zahlen musste. Trotzdem konnte er seine grundsätzliche Arbeit in der Form des Lehrbuchs des IPR publizieren. Obschon seine Tätigkeit weiterhin nicht direkt beschränkt wurde, war für ihn eine Professur ausgeschlossen.

Nach dem Umsturz 1989 wurde er zum Professor ernannt und für kurze Zeit wurde er Leiter des Lehrstuhls des internationalen Rechts. Infolge der Reorganisation der Fakultät wurde er auf den Lehrstuhl des Handelsrechts umverlegt. Diesen leitete er auch kurze Zeit. Die Situation der Fakultät „störte“ ihn nicht und auch die weitere Entwicklung der Fakultät lag ihm nicht am Herzen.

Außer seiner pädagogischen und wissenschaftlichen Tätigkeit war Kučera auch in anderen Bereichen tätig. Überraschenderweise wurde er nach 1989 wieder Anwalt und blieb es bis zum Jahre 2007. Fast 40 Jahre war er Schiedsrichter bei dem Schiedsgericht der Wirtschaftskammer in Prag, über längere Zeit sogar dessen Vizepräsident. Ohne Kontakte mit den Kollegen aus anderen Ländern zu pflegen, war er Mitglied mehrerer Delegationen in den Verhandlungen der Haag'schen Konferenz für internationales Privatrecht. Er wirkte bei der Entstehung des Handelsgesetzbuches 1980-1990 mit.

Länger als ein Jahrzehnt konzentrierte er sich aber auf die neue Kodifizierung des IPR. Es war mit seinem Beitrag zum Gesetz über internationales Privatrecht (Nr. 91/2012 Slg.), das das alte Gesetz aus dem Jahre 1963 ablöste.

In Kučeras Nachlass befinden sich mehr als 120 Werke. Einen besonderen Teil nehmen seine Lehrbücher ein (insgesamt 23 Bücher und Skripten), dann sind es Studien (10) und bedeutende Artikel (25). Von hoher Qualität ist sein erster Kommentar zum Gesetz 97/1963 Slg., dem IPR aus diesem Jahre, und von großer Bedeutung sind auch seine drei Monografien. Die meisten Werke sind in der Form von Anmerkungen, Rezensionen und Entscheidungskommentaren (über 50) geschrieben. 
Von größter Relevanz sind seine Werke im Bereich des IPR. Er widmete sich sowohl methodologischen Problemen als auch ganz konkreten Fragen. An der Spitze steht jedoch sein Lehrbuch. Es geht um ein methodologisch fast perfektes Werk unter dem Einfluss der deutschen Lehre. Sein Lehrbuch füllte eine tragische Lücke, die zwischen den Werken seit dem Beginn des 20. Jahrhunderts in der tschechischen Literatur existierte und die nur unvollständig durch Skripten von Bystrický überbrückt werden konnte. Kučeras Lehrbuch stellt zum einen ein Beispiel für die Realisierung der traditionellen, damals feindlichen Methodologie des kapitalistischen Auslands dar, das provozieren konnte, zum anderen hat das Regime dieses Buch einigermaßen legitimiert. Bis zum heutigen Tag hatte das Lehrbuch sieben Auflagen erzielt, wobei an der letzten auch seine Mitarbeiter mitgewirkt haben. Nach allgemeiner Ansicht ist es allerdings für die Studenten, die IPR als Pflichtfach absolvieren müssen, zu anspruchsvoll. Für ihr Studium dient besser sein Handbuch der Fälle und Beispiele aus dem Jahre 1992.

$\mathrm{Zu}$ Kučeras Nachlass gehören auch die bedeutende Studie „Občanskoprávní vztahy s mezinárodním prvkem a způsoby jejich právní úpravy“, 1977 (Bürgerlichrechtliche Verhältnisse mit ausländischem Bezug und die Formen ihrer Regulierung) aus dem Jahre 1967 und „Přímé normy jako prostředek právní úpravy v občanskoprávních vztazích s mezinárodním prvkem“, 1980 (Direkte Normen als Mittel der Regelung von bürgerlichrechtlichen Verhältnissen mit ausländischem Bezug), sein Beitrag als Beweis für sein Konzept des Systems von IPR. Erwähnungswert ist noch die Studie über die Struktur und Qualifizierung von Kollisionsnormen („Struktura a třídění kolizních norem“) aus dem Jahre 1982.

Professor Kučera hinterlässt drei Kinder und mehrere Enkelkinder. In ihm ist eine bescheidene, verschlossene, aber gutmütige Person verstorben. 



\title{
Studia
}

\author{
Wojciech Dybka*
}

\section{Trademark trolling jako przykład zgłoszenia znaku towarowego w złej wierze}

\begin{abstract}
The subject of this paper relates to trademark trolling - a phenomenon, which may have a negative impact on entrepreneurs and their businesses. A trademark troll shall be defined as a person, who applies for registration of trade marks without an actual intention to make a commercial use of them. A trademark troll's objective is to cause other enterpreneurs to pay for a license enabling to use those trade marks by threatening them with a litigation.

The aim of the paper is to consider whether the Polish and the European Union's legislation guarantees the enterpreneurs a sufficient protection from trademark trolls. This protection can be provided during the trade mark's registration procedure initiated by a trademark troll, mostly with the use of absolute ground for refusal to register a trade mark, which is making an application in bad faith. Apart from that, negative effects of trademark trolling can be decreased after the registration procedure - the registration of trademark can be declared invalid by the Patent Office, whereas the possible trademark troll's legal action against the enterpreneur harmed by trolling could be dismissed by the court, as the action would be contrary to the principles of social co-existence.
\end{abstract}

Keywords: Trademark trolling, registration of trademark, bad faith, European Union law, Polish law, abuse of law, legal protection

* Mgr, Uniwersytet Jagielloński w Krakowie. 


\section{Zjawisko trademark trollingu i jego skutki}

Pojęcie trademark trolling nie występuje powszechnie w polskiej literaturze prawniczej. Opisywane przez nie zjawisko nie stało się jeszcze przedmiotem obszernego orzecznictwa sądowego, próżno też szukać bezpośrednich odniesień do niego w treści ustawy Prawo własności przemysłowej ${ }^{1}$. Nie oznacza to jednak, że tego rodzaju praktyki wymierzone w cudzą własność intelektualną lub dobra osobiste nie są lub nie będa kierowane przeciwko polskim przedsiębiorcom. Rodzi to potrzebę zwrócenia uwagi na te zachowania, aby zapobiec ich negatywnym skutkom.

W literaturze zagranicznej trademark trolling definiuje się jako zachowanie polegajace na zgłaszaniu oznaczeń w celu uzyskania praw ochronnych na znaki towarowe, jednakże bez rzeczywistego zamiaru ich używania w celu oznaczania własnych towarów lub usług ${ }^{2}$. Trademark troll zmierza do uniemożliwienia korzystania z zarejestrowanych przez siebie znaków towarowych innym uczestnikom obrotu. Jego działania mogą być wymierzone zarówno w przedsiębiorców, którzy korzystaja z oznaczeń stanowiących przedmiot prawa ochronnego uzyskanego przez trolla, jak też w przedsiębiorców, którzy mogliby w przyszłości powziąć zamiar prowadzenia działalności gospodarczej z wykorzystaniem takiego oznaczenia. Praktyka trolla zazwyczaj polega na kierowaniu względem nich wezwań do uiszczenia opłaty bądź zawarcia odpłatnej umowy licencji na korzystanie ze znaku towarowego, z zastrzeżeniem, że w przypadku braku zaakceptowania stawianych warunków będą narażeni na proces sądowy i związane z nim koszty. Bliżej charakteryzując metody działania trolli, wskazać można klasyczny trademark trolling stosowany przez przedsiębiorcę, który aby utrudnić działalność gospodarczą konkurenta, podejmuje działania w celu rejestracji używanych przez niego znaków towarowych, oraz trademark squatting, polegajacy najczęściej na rejestracji przez dystrybutora handlującego na rynku krajowym towarami zagranicznego producenta oznaczeń stosowanych przez tego kontrahenta ${ }^{3}$.

1 Ustawa z dnia 30 czerwca 2000 r. - Prawo własności przemysłowej. Tekst jedn. Dz.U. 2017, poz. 776 z późn. zm. [dalej: p.w.p.].

${ }^{2}$ A.B. Folgers: The Seventh Circuit's Approach to Deterring the Trademark Troll: Say Goodbye to Your Registration and Pay the Costs of Litigation. Seventh Circuit 2007, Vol. 3, s. 453, https://www.kentlaw.iit.edu/sites/ck/files/public/academics/jd/7cr/v3-1/fol gers.pdf [Data dostępu: 31 grudnia 2017 r.].

${ }_{3}^{3}$ Szerzej M. Ryba: Zjawisko trademark trollingu - problem, zjakim moga zmierzyć się polscy przedsiębiorcy po zmianie procedury uzyskiwania prawa ochronnego na znak towarowy. „Problemy Prawa Prywatnego Międzynarodowego” 2017, T. 21, s. 111. 
Ofiarami trademark trollingu są więc w szczególności przedsiębiorcy działajacy pod określoną firmą, używający oznaczeń zarówno dla swojego przedsiębiorstwa, jak i dla oferowanych towarów i usług, których to oznaczeń z różnych powodów nie rejestrują w krajowym urzędzie patentowym lub w Urzędzie Unii Europejskiej do spraw Własności Intelektualnej [dalej: EUIPO] w celu uzyskania prawa ochronnego na znak towarowy.

Trademark trolling jest zatem zachowaniem pasożytniczym, sprzecznym z zasadami uczciwości kupieckiej, zmierzającym do czerpania nieuzasadnionych korzyści kosztem innych podmiotów. Warto więc zastanowić się, czy polskie oraz unijne ${ }^{4}$ prawo znaków towarowych zawieraja odpowiednie instrumenty prawne, pozwalające na skuteczną ochronę przedsiębiorców przed niesłusznymi skutkami trademark trollingu.

\section{Ochrona przed trademark trollingiem zmierzająca do uniemożliwienia uzyskania lub utrzymania prawa ochronnego na znak towarowy}

Ochrona przedsiębiorcy narażonego na trademark trolling może być realizowana na różnych płaszczyznach. W pierwszej kolejności warto zwrócić uwage na podstawy odmowy udzielenia prawa ochronnego na znak towarowy zgłaszany przez podmiot stosujący trolling. Po wprowadzeniu w życie reformy polskiego prawa znaków towarowych ${ }^{5}$, której element stanowiła istotna modyfikacja postępowania rejestracyjnego, Urząd Patentowy Rzeczypospolitej Polskiej [dalej: UPRP] w ramach tego postępowania bada z urzędu tylko niektóre spośród negatywnych przesłanek udzielenia i utrzymania prawa ochronnego na znak towarowy

${ }^{4}$ Chodzi o dyrektywę Parlamentu Europejskiego i Rady (UE) nr 2015/2436 z dnia 16 grudnia 2015 r., mająca na celu zbliżenie ustawodawstw państw członkowskich odnoszących się do znaków towarowych (Dz.Urz. UE z dnia 23 grudnia 2015 r., L 336, s. 1 i nast.) [dalej: dyrektywa 2015/2436], która z dniem 15 stycznia 2019 r. zastąiła dyrektywę Parlamentu Europejskiego i Rady 2008/95/WE z dnia 22 października 2008 r. o identycznej nazwie (Dz.Urz. UE z listopada 2008 r., L 299, s. 25 i nast.) [dalej: dyrektywa 2008/95/WE], a także rozporządzenie Parlamentu Europejskiego i Rady (UE) 2017/1001 z dnia 14 czerwca 2017 r. w sprawie znaku towarowego Unii Europejskiej (Dz.Urz. UE z dnia 16 czerwca 2017 r., L 154, s. 1-99) [dalej: rozporządzenie 2017/1001].

${ }_{5}$ Zob. ustawę z dnia 11 września 2015 r. o zmianie ustawy - Prawo własności przemysłowej. Dz.U. 2015, poz. 1615. 
(tzw. przeszkody bezwzględne ${ }^{6}$ ). Przeszkody względne są zaś brane pod uwage $\mathrm{w}$ przypadku wniesienia sprzeciwu przez podmiot uprawniony do wcześniejszego znaku towarowego lub uprawniony z tytułu wcześniej powstałego prawa osobistego lub majątkowego ${ }^{7}$. Skutkiem tych zmian ma być w szczególności przyspieszenie postępowania rejestracyjnego ${ }^{8}$. Warto jednocześnie przypomnieć, że model zakładający uwzględnianie z urzędu wyłącznie przeszkód bezwzględnych przewidziany został również w przepisach przywołanego wcześniej rozporządzenia 2017/1001 w sprawie zna$\mathrm{ku}$ towarowego Unii Europejskiej, wobec czego procedura uzyskiwania obydwu kategorii praw wyłacznych do znaku towarowego, odpowiednio przed UPRP oraz EUIPO, została do pewnego stopnia ujednolicona.

Najistotniejszy dla tematyki trademark trollingu pozostaje $\mathrm{w}$ tym względzie fakt, że w prawie polskim jako jedną z przeszkód bezwzględnych ustanowiono zgłoszenie oznaczenia w złej wierze ${ }^{9}$. Udzielone już

${ }^{6}$ Przeszkody bezwzględne wymienione zostały enumeratywnie w art. $129^{1}$ p.w.p. Najkrócej ujmując istotę przeszkód bezwzględnych, należy stwierdzić, że dotyczą one wad zgłaszanego oznaczenia tkwiących w samej jego istocie, które uniemożliwiają prawidłowe spełnianie przez oznaczenie funkcji znaku towarowego (zwłaszcza funkcji odróżniajaccej, pozwalającej na odróżnianie towarów i usług jednego przedsiębiorstwa od towarów i usług innego przedsiębiorstwa). Zob. szerzej R. Skubisz, M. Mazurek: Względne podstawy odmowy udzielenia prawa ochronnego na znak towarowy. W: „System Prawa Prywatnego". T. 14B: Prawo własności przemysłowej. Red. R. Skubisz. Warszawa 2017, s. $725-728$.

${ }^{7}$ Przeszkody względne wymienione zostały enumeratywnie w art. $132^{1}$ p.w.p.

${ }^{8}$ K. Sztobryn: (Nie tylko) krytyczne spojrzenie na nowe przepisy ustawy prawo wtasności przemysłowej dotyczace sprzeciwu wobec zgtoszenia znaku towarowego. „Przegląd Prawa Handlowego" 2016, nr 8, s. 26-31. Autorka przywołuje statystyki Raportu Instytutu Maxa Plancka, z których wynika, że ograniczenie aktywności krajowego urzędu patentowego do badania z urzędu wyłącznie przeszkód bezwzględnych nie ma decydującego wpływu na dynamikę postępowania rejestracyjnego. W kontekście oceny analizowanej nowelizacji zob. również: P. Kostański, T. Marek: Wybrane zagadnienia nowelizacji europejskiego prawa znaków towarowych. „Zeszyty Naukowe Uniwersytetu Jagiellońskiego. Prace z Prawa Własności Intelektualnej” 2015, z. 130, s. 99-100.

${ }_{9}$ Zob. art. $129^{1}$ ust. 1 pkt 6 p.w.p. W odniesieniu do przepisów prawa unijnego warto zauważyć, że dyrektywa nr 2008/95/WE traktowała zgłoszenie znaku towarowego w złej wierze jako opcjonalną przeszkodę dla uzyskania/podstawę do unieważnienia prawa ochronnego na znak towarowy, która państwa członkowskie mogły, ale nie musiały wprowadzać do krajowych porządków prawnych (zob. w szczególności art. 3 ust. 2 lit. d oraz art. 4 ust. 4 lit. g tej dyrektywy). W przepisach nowej dyrektywy nr 2015/2436 okoliczność zgłoszenia znaku towarowego w złej wierze została już uregulowana jako obowiązkowa przesłanka unieważnienia prawa ochronnego na znak towarowy, a ponadto - opcjonalnie dla ustawodawców krajowych — jako przesłanka odmowy udzielenia prawa ochronnego (zob. art. 4 ust. 2 dyrektywy). Zob. też J. Kępiń ski: Jakie zmiany czekaja prawo znaków towarowych w świetle dyrektywy 2015/2436? W: „Experientia docet”. Księga jubileuszowa ofiarowana Pani Profesor Elżbiecie Traple. Red. P. Kostański, P. Podrecki, T. Targosz. Warszawa 2017, s. 525-542. 
prawo ochronne może być też z tej przyczyny unieważnione ${ }^{10}$. Ponadto stosownie do art. 59 ust. 1 lit. b rozporzadzenia w sprawie znaku towarowego Unii Europejskiej powyższa okoliczność stanowi podstawę unieważnienia unijnego znaku towarowego.

Znaczenie, jakie należy przypisać pojęciu „zgłoszenie znaku towarowego w złej wierze", stanowi przedmiot dysput zarówno na gruncie prawa polskiego, jak i prawa unijnego. Należy także pamiętać o jego wspólnotowej genezie, jako że pochodzi ono z pierwszej wspólnotowej dyrektywy, mającej na celu zbliżenie ustawodawstw państw członkowskich odnoszących się do znaków towarowych ${ }^{11}$. $\mathrm{Z}$ tego też względu dla dokonania jego wykładni, na której powinno być oparte orzecznictwo krajowych sądów oraz Urzędu Patentowego, kluczowe znaczenie odgrywa orzecznictwo Trybunału Sprawiedliwości Unii Europejskiej ${ }^{12}$ [dalej: TSUE].

W literaturze wskazuje się, że interpretując pojęcie złej wiary, można odwoływać się do stanu psychicznego ocenianego podmiotu (zła wiara w znaczeniu subiektywnym) lub do negatywnej oceny jego zachowania z perspektywy pożądanych norm etycznych (zła wiara w znaczeniu obiektywnym $)^{13}$. Jeśli chodzi o badanie złej wiary zgłaszającego znak towarowy, to trafne jest, moim zdaniem, podejście, które uwzględnia zarówno potrzebę zestawienia zachowania zgłaszającego z zobiektywizowanymi wzorcami postępowania w stosunkach zawodowych i handlowych, jak również wzięcia pod uwagę pobudek, którymi kierował się podmiot dążący do uzyskania prawa ochronnego na znak towarowy ${ }^{14}$. Do obydwu tych sfer odwołuje się w swoim orzecznictwie TSUE. Analizując poświęcone temu zagadnieniu orzecznicze wypowiedzi Trybunału, należy wskazać, że dokonanie oceny, czy zgłaszający znak towarowy działał w złej wierze, wymaga uwzględnienia wszelkich okoliczności towarzyszących

${ }^{10}$ Artykuł 164 ust. 1 w zw. z art. 129 ust. 1 pkt 6 p.w.p.

${ }_{11}$ Dyrektywa Rady z dnia 21 grudnia 1988 r. mająca na celu zbliżenie ustawodawstw Państw Członkowskich odnoszących się do znaków towarowych 89/104/EWG. Dz.Urz. WE z dnia 11 lutego 1989 r., L 040, s. 1 i nast.

${ }^{12} \mathrm{Na}$ tę okoliczność uwagę zwraca sam Trybunał, podkreślając, że pojęcie złej wiary zgłaszającego znak towarowy stanowi autonomiczne pojęcie prawa unijnego, które powinno być jednolicie rozumiane na terenie wszystkich państw członkowskich. Zob. wyrok Trybunału Sprawiedliwości Unii Europejskiej z dnia 27 czerwca 2013 r., C-320/12. Malaysia Dairy Industries Pte. Ltd v. Ankenævnet for Patenter og Varemærker. ECLI:EU:C:2013:435, pkt. 20-29.

${ }_{13}$ Zob. m.in. M. Witkowska, A. Michalak: Komentarz do art. $129^{1}$ p.w.p. W: Prawo własności przemysłowej. Komentarz. Red. A. Michalak. 2016. LEGALIS, nb 52-54.

${ }^{14}$ Zob. K. Szczepanowska-Kozłowska: Bezwzględne przeszkody rejestracji znaku towarowego. W: „System Prawa Prywatnego”. T. 14B: Prawo własności przemystowej. Red. R. Skubisz..., s. 693-694, która powołuje się na pogląd M. Pilicha w odniesieniu do klauzuli dobrej wiary, sformułowanej w Konwencji Narodów Zjednoczonych z 1980 r. o umowach międzynarodowej sprzedaży towarów. 
zgłoszeniu. Należy m.in. ustalić, czy zgłaszający wiedział lub powinien wiedzieć, że osoba trzecia używa już identycznego lub podobnego oznaczenia dla towarów identycznych lub podobnych do tych objętych zgłoszeniem. Sama wiedza zgłaszającego o tym, że w obrocie stosowane jest już podobne lub identyczne oznaczenie nie jest jednak wystarczająca, by przyjąć, że działał on w złej wierze ${ }^{15}$. Konieczne jest również wzięcie pod uwagę zamiaru, którym kierował się zgłaszajacy, stopnia ochrony prawnej, z której korzystają oznaczenia zgłoszone do rejestracji, oraz ewentualnego istnienia oznaczeń z nimi kolidujących (ich ochrona może wynikać chociażby z faktu korzystania z oznaczenia przez podmioty trzecie jeszcze przed zgłaszającym lub korzystania równoległego ze zgłaszającym), jak również stopnia powszechnej znajomości, która charakteryzuje oznaczenie w chwili jego zgłoszenia ${ }^{16}$. W unijnym oraz polskim orzecznictwie wskazuje się nadto, że w toku badania, czy zgłoszenie nastąpiło w złej wierze, należy uwzględnić również takie okoliczności, jak: skorzystanie z renomy cudzego oznaczenia lub jej zagrożenie, naruszenie stosunku zaufania łączacego zgłaszającego z podmiotem trzecim, polegajace na zgłoszeniu oznaczenia kolidujacego z oznaczeniem należącym do tamtego podmiotu ${ }^{17}$, pochodzenie zgłoszonego oznaczenia i okoliczności jego używania, począwszy od jego stworzenia, strategię handlowa, w którą wpisane jest dokonanie zgłoszenia, chronologię wydarzeń związanych z dokonaniem zgłoszenia ${ }^{18}$ czy też zamiar obejścia przez zgłaszającego obowiązków umownych łączących go z podmiotem trzecim ${ }^{19}$. Badanie

15 Wyrok Trybunału Sprawiedliwości Unii Europejskiej z dnia 11 czerwca 2009 r., C-529/07 Chocoladefabriken Lindt \& Sprüngli AG v. Franz Hauswirth GmbH. Zb. Orz. 2009, s. I-04893, pkt. 39-40. Na tę okoliczność w polskiej doktrynie wskazywała m.in. U. Promińska, podkreślając, że odwołanie się do znaczenia złej wiary w rozumieniu przepisów prawa cywilnego mogłoby jedynie stanowić punkt wyjścia dla wykładni przepisów p.w.p. Aby doszło do zgłoszenia znaku towarowego w złej wierze, konieczne jest bowiem zaistnienie dodatkowych okoliczności, w szczególności dokonanie zgłoszenia w innym celu niż stosowanie go do oznaczania swoich towarów lub usług. Zob. U. Promińska: Znaki towarowe i prawa ochronne. W: M. du Vall, E. Nowińska, U. Promińska: Prawo własności przemystowej. Warszawa 2011, s. 293.

${ }^{16}$ Ibidem, pkt. $46-52$.

17 Zob. m.in. wyrok Wojewódzkiego Sądu Administracyjnego w Warszawie z dnia 20 listopada 2016 r., VI SA/Wa 1356/16. LEX nr 2270758 oraz wyrok Naczelnego Sądu Administracyjnego z dnia 24 listopada 2010 r., II GSK 1011/09. LEX nr 746025.

18 Zob. m.in. wyrok Sądu Unii Europejskiej z dnia 5 października 2016 r., T-456/15. Foodcare sp. z o.o. v. Urząd Unii Europejskiej ds. Własności Intelektualnej. ECLI:EU: $\mathrm{T}: 2016: 597$, pkt 28.

${ }^{19}$ Ibidem, pkt 44. Szerzej o zachowaniach kwalifikowanych w polskim orzecznictwie jako zgłoszenie znaku towarowego w złej wierze M. Kulikowska: Zgłoszenie wspólnotowego znaku towarowego w złej wierze. Glosa do wyroku TS z dnia 11 czerwca 2009 r., C-529/07. „Glosa” 2010, nr 2, s. 79-86. 
wymienionych okoliczności zmierza więc do ustalenia, czy zgłaszający znak towarowy działał $\mathrm{w}$ zgodzie $\mathrm{z}$ powszechnie akceptowanymi standardami etycznego zachowania oraz uczciwymi praktykami handlowymi, przy jednoczesnym uwzględnieniu zamiaru, którym kierował się ten podmiot. W szczególności ocenić należy, czy celem zgłaszającego było wyłącznie uniemożliwienie korzystania z oznaczeń innym przedsiębiorcom, bez zamiaru samodzielnego ich używania. Zamiar zaś — jako okoliczność subiektywna - podlega rekonstrukcji na podstawie ustalonych obiektywnych okoliczności zgłoszenia ${ }^{20}$.

Trzeba jednocześnie dodać, że zgodnie z unijnym orzecznictwem, ciężar wykazania okoliczności świadczacych o zgłoszeniu oznaczenia w złej wierze spoczywa na podmiocie, który wnosi o unieważnienie prawa ochronnego ${ }^{21}$. W polskim orzecznictwie i doktrynie podkreśla się również, że okoliczność ta wynika z domniemania dobrej wiary przyjętego w art. 7 k.c. ${ }^{22}$

Odnoszac poczynione ustalenia do zjawiska trademark trollingu, które - jak się przyjmuje - polega na zgłaszaniu oznaczeń w celu uzyskania prawa ochronnego na znak towarowy wyłącznie, aby uniemożliwić korzystanie z oznaczenia przez inne podmioty (w szczególności przedsiębiorców, którzy rozpoczęli korzystanie z oznaczenia przed jego zgłoszeniem przez trolla) oraz osiaganie korzyści finansowych z tytułu opłat licencyjnych, należy stwierdzić, że takie zachowanie wypełnia znamiona zgłoszenia znaku towarowego $\mathrm{w}$ złej wierze $\mathrm{w}$ rozumieniu przyjętym przez prawo unijne oraz implementujące je prawo polskie ${ }^{23}$.

${ }^{20}$ Wyrok Trybunału Sprawiedliwości Unii Europejskiej z dnia 11 czerwca 2009 r., C-529/07. Chocoladefabriken Lindt \& Sprüngli AG v. Franz Hauswirth GmbH. Zb. Orz. 2009, s. I-04893, pkt 42 oraz m.in. wyrok Wojewódzkiego Sądu Administracyjnego w Warszawie z dnia 24 maja 2011 r., VI SA/Wa 457/11. LEX nr 1094967.

${ }_{21}$ Zob. m.in. wyrok Sądu Unii Europejskiej z dnia 5 października 2016 r., T-456/15. Foodcare sp. z o.o. v. Urząd Unii Europejskiej ds. Własności Intelektualnej. ECLI:EU:T: 2016:597, pkt 23 .

${ }^{22}$ M.in. M. Andrzejewski, P. Kostański: Komentarz do art. 131 p.w.p. W: Prawo własności przemysłowej. Red. P. Kostański. 2014. LEGALIS, nb 10 oraz wyrok Wojewódzkiego Sąu Administracyjnego w Warszawie z dnia 27 listopada 2008 r., VI SA/Wa 1388/07. LEGALIS nr 267102.

${ }^{23}$ Zob. m.in.: wyrok Trybunału Sprawiedliwości Unii Europejskiej z dnia 11 czerwca 2009 r., C-529/07 Chocoladefabriken Lindt \& Sprüngli AG v. Franz Hauswirth GmbH. Zb. Orz. 2009, s. I-04893, pkt 44; wyrok Naczelnego Sądu Administracyjnego z dnia 24 listopada 2010 r., II GSK 1011/09. LEX nr 746025; wyrok Wojewódzkiego Sądu Administracyjnego w Warszawie z dnia 24 maja 2011 r., VI SA/Wa 457/11. LEX nr 1094967. Przywołane wyroki nie odnoszą się bezpośrednio do zjawiska trademark trollingu, niemniej jednak w treści ich uzasadnień wyraźnie wskazano, że zgłoszenie znaku towarowego bez zamiaru jego używania w obrocie, a wyłącznie w celu uniemożliwiania wejścia na rynek innym podmiotom, stanowi przykład zgłoszenia oznaczenia w złej wierze. Wo- 
Ustalenie złej wiary w rozumieniu przepisów unijnego prawa znaków towarowych wymaga więc zarówno uwzględnienia okoliczności subiektywnych występujących po stronie zgłaszającego, jak również dokonania oceny całokształtu okoliczności zgłoszenia w świetle kryteriów odwołujacych się do zasad uczciwości handlowej. Rodzi to pewien problem praktyczny. Przeprowadzenie opisanego badania wymaga bowiem powzięcia przez Urząd Patentowy informacji, które nie będą wynikały z treści samego zgłoszenia. Nawet fakt, że zarejestrowano lub zgłoszono z wcześniejszym pierwszeństwem znaki towarowe podobne do zgłaszanego lub identyczne ze zgłaszanym nie będzie wystarczający do stwierdzenia złej wiary. Konieczne byłoby bowiem powzięcie przez Urząd Patentowy informacji pozwalajacych na ustalenie zamiaru zgłaszającego oraz innych okoliczności zgłoszenia, co najczęściej wymagałoby przedstawienia argumentów przez podmiot będacy ofiarą trademark trollingu ${ }^{24}$. To zaś w obecnym kształcie procedury rejestracji znaków towarowych może nastąpić w przypadku złożenia przez poszkodowanego przedsiębiorcę wniosku o unieważnienie uzyskanego przez trolla prawa ochronnego na znak towarowy lub - jeszcze $\mathrm{w}$ toku procedury rejestracyjnej - sprzeciwu wobec zgłoszenia albo uwag do zgłoszenia w trybie art. $146^{1} \S 4$ p.w.p.

W kontekście uwag do zgłoszenia znaku towarowego warto podkreślić, że mogą one obejmować istnienie okoliczności stanowiących bezwzględne przesłanki odmowy udzielenia prawa ochronnego (a więc również zgłoszenie znaku w złej wierze), a wystąić z nimi może nieograniczony krąg podmiotów. Osoba zgłaszająca uwagi nie staje się jednak stroną postępowania, a tym samym nie otrzyma od UPRP informacji o sposobie ich rozpoznania ${ }^{25}$. Podobny tryb przewidziano w przepisach rozporzadzenia w sprawie znaku towarowego Unii Europejskiej ${ }^{26}$.

Sprzeciw wobec zgłoszenia znaku towarowego może zapobiec udzieleniu trademark trollowi prawa ochronnego na znak towarowy, przy czym trzeba pamiętać, że termin na jego wniesienie wynosi trzy miesiące od daty ogłoszenia o zgłoszeniu znaku towarowego w „Biuletynie Urzędu Patentowego" ${ }^{27}$. Jeżeli ofiarą trollingu jest przedsiębiorca, który zanied-

jewódzki Sąd Administracyjny w Warszawie w przywołanym wyroku z dnia 24 maja 2011 r. stwierdził, że takie zachowanie stanowi wręcz podstawową formę zgłoszenia znaku w złej wierze.

${ }^{24}$ Problem ten dostrzeżono w doktrynie. Zob. m.in. K. Sztobryn: (Nie tylko) krytyczne spojrzenie..., s. 26.

${ }^{25}$ M. Witkowska: Komentarz do art. $146^{1}$ p.w.p. W: Prawo własności przemysłowej. Red. P. Kostański..., nb 3-4.

${ }^{26}$ Zob. art. 45 rozporządzenia 2017/1001.

${ }^{27}$ Zob. art. $152^{6 a}$ ust. 1 oraz art. $152^{17}$ ust. 1 p.w.p. Szerzej o procedurze rozpatrywania sprzeciwu M. Rutkowska: Uzyskanie oraz utrzymanie $w$ mocy prawa ochronnego na znak towarowy (zagadnienia wybrane). „Monitor Prawniczy” 2016, nr 23, s. 1258. 
bał rejestracji używanych przez siebie oznaczeń z powodu braku dostatecznej wiedzy na temat prawa znaków towarowych, to istnieje znaczne prawdopodobieństwo, że taka osoba nie monitoruje na bieżąco zgłoszeń znaków towarowych publikowanych w „Biuletynie Urzędu Patentowego”, co jest niezbędne do powzięcia wiedzy o tym, że termin na wniesienie sprzeciwu rozpoczął swój bieg. W kontekście podstaw sprzeciwu należy wyjaśnić, że nie należy do nich okoliczność zgłoszenia znaku towarowego w złej wierze. Podstawy te zostały wskazane w art. $152^{17}$ ust. 1 p.w.p. ${ }^{28}$ Przywołany przepis w analizowanym kontekście odsyła bowiem wyłącznie do względnych przesłanek odmowy rejestracji znaku wymienionych w art. $132^{1}$ ust. $1-3$ p.w.p., obejmujących w szczególności kolizję z wcześniejszym zarejestrowanym znakiem towarowym ${ }^{29}$ albo z prawem osobistym lub majątkowym przysługującym wnoszacemu sprzeciw. Z uwagi na fakt, że ofiara trademark trollingu jest przedsiębiorca, który nie zarejestrował swoich znaków towarowych, sprzeciw z jego strony może być oparty w zasadzie na naruszeniu praw majątkowych i dóbr osobistych (chyba że jego oznaczenie mogłoby zostać sklasyfikowane jako znak towarowy powszechnie znany). Sporne wśród przedstawicieli polskiej doktryny jest jednak to, czy korzystanie z niezarejestrowanego oznaczenia podlega takiej samej ochronie, jak prawa podmiotowe, o których mowa w powołanym art. $132^{1}$ ust. 1 pkt 1 p.w.p. Kwestia ta będzie jeszcze omawiana w niniejszym artykule.

W przypadku niewniesienia sprzeciwu w ustawowym terminie lub braku możliwości oparcia się na którejśs ze względnych przesłanek odmowy udzielenia prawa ochronnego na znak towarowy ofiara trademark trollingu powinna wystapić z wnioskiem o unieważnienie prawa ochronnego na podstawie art. 164 ust. 1 p.w.p. ${ }^{30}$ Złożenie wniosku o unieważnienie prawa ochronnego na znak towarowy nie zostało ograniczone żadna cezura czasowa. Wprawdzie, jak stanowi art. 165 ust. 1 pkt 1 p.w.p., „Z wnioskiem o unieważnienie prawa ochronnego nie można wystąić z powodu kolizji z wcześniejszym znakiem bądź naruszenia praw osobistych lub majątkowych wnioskodawcy, jeżeli przez okres pięciu kolejnych lat używania zarejestrowanego znaku wnioskodawca, będąc świadomym jego używania, nie sprzeciwiał się temu", niemniej jednak, zgodnie

${ }^{28}$ Analogiczna sytuacja dotyczy sprzeciwu wobec rejestracji znaku towarowego Unii Europejskiej, co wynika z art. 46 ust. 1—2 rozporządzenia 2017/1001 wskazujaccego podstawy wnoszenia sprzeciwu.

${ }_{29}$ Wymóg rejestracji nie dotyczy w tym kontekście znaku powszechnie znanego, co wynika z art. $132^{1}$ ust. 1 pkt 5 p.w.p.

${ }^{30}$ Unieważnienie znaku towarowego Unii Europejskiej jest możliwe zgodnie z podstawami wymienionymi w art. 59-60 rozporządzenia nr 2017/1001, które podobnie jak w prawie polskim obejmują zarówno bezwzględne, jak i względne odmowy rejestracji znaku. 
z ust. 2 przywołanego artykułu, wskazanego wyżej ograniczenia nie stosuje się w przypadkach, gdy uprawniony z tytułu prawa ochronnego na znak towarowy uzyskał je, działając w złej wierze.

Jak już wskazano, zarówno w sprzeciwie, jak i we wniosku o unieważnienie prawa ochronnego poszkodowany przedsiębiorca będzie mógł powołać się na kolizję prawa ochronnego z przysługującymi przedsiębiorcy prawami osobistymi i majątkowymi. Wystąpi ona wtedy, gdy używanie zgłoszonego znaku towarowego naruszałoby prawa podmiotowe ofiary trollingu (przede wszystkim: prawo do firmy, dobra osobiste, prawa autorskie oraz prawa własności przemysłowej, np. prawo z rejestracji wzoru przemysłowego ${ }^{31}$ ). Tego rodzaju kolizje rozstrzyga się zgodnie z zasada, że priorytet należy nadać ochronie prawa, które powstało wcześniej. Tym samym w przypadku, w którym trademark troll zgłosiłby oznaczenie naruszające prawo do firmy innego przedsiębiorcy, który pod tą firmą prowadzi już działalność gospodarcza, sprzeciw/wniosek o unieważnienie prawa ochronnego złożony przez tego przedsiębiorcę zasługuje na uwzględnienie ${ }^{32}$.

Warto zwrócić uwage na problem kolizji znaku zgłaszanego przez podmiot będacy trollem z oznaczeniem cudzego przedsiębiorstwa niebędącego jednak firmą w rozumieniu art. $43^{5} \S 1$ k.c. oraz z niezarejestrowanym oznaczeniem, pod którym przedsiębiorca wprowadza do obrotu towary lub oferuje usługi. Oznaczenie przedsiębiorstwa, a także oznaczenia towarów oraz usług podlegają bowiem ochronie wynikającej z ustawy o zwalczaniu nieuczciwej konkurencji ${ }^{33}$. Zachowania polegajace

${ }^{31}$ Zob. m.in. M. Witkowska, A. Michalak: Komentarz do art. $132^{1}$ p.w.p. W: Prawo własności przemysłowej. Red. P. Kostański..., nb 4 oraz R. Skubisz, M. Mazurek: Względne podstawy..., s. 821-824.

${ }_{32}$ Zob. wyrok Naczelnego Sądu Administracyjnego z dnia 10 stycznia 2002 r., II SA 3390/01. LEGALIS nr 54602.

${ }^{33}$ Ustawa z dnia 16 kwietnia 1993 r. Tekst jedn. Dz.U. 2003, nr 153, poz. 1503 ze zm. [dalej: u.z.n.k.]. Należy zwrócić szczególną uwagę na dwa stypizowane w jej treści czyny nieuczciwej konkurencji. Jak stanowi art. 5 u.z.n.k., „Czynem nieuczciwej konkurencji jest takie oznaczenie przedsiębiorstwa, które może wprowadzić klientów w błąd co do jego tożsamości, przez używanie firmy, nazwy, godła, skrótu literowego lub innego charakterystycznego symbolu wcześniej używanego, zgodnie z prawem, do oznaczenia innego przedsiębiorstwa”. Zgodnie zaś z art. 10 ust. 1 u.z.n.k., „Czynem nieuczciwej konkurencji jest takie oznaczenie towarów lub usług albo jego brak, które może wprowadzić klientów w błąd co do pochodzenia, ilości, jakości, składników, sposobu wykonania, przydatności, możliwości zastosowania, naprawy, konserwacji lub innych istotnych cech towarów albo usług, a także zatajenie ryzyka, jakie wiąże się z korzystaniem z nich". Ustęp 2 przywołanego przepisu stanowi natomiast, że „Czynem nieuczciwej konkurencji jest również wprowadzenie do obrotu towarów w opakowaniu mogącym wywołać skutki określone w ust. 1, chyba że zastosowanie takiego opakowania jest uzasadnione względami technicznymi”. 
na stosowaniu oznaczeń wprowadzających w błąd stanowią bowiem czyny nieuczciwej konkurencji w rozumieniu przepisów przywołanej ustawy. Nasuwa się więc pytanie, czy przedsiębiorcom korzystającym z ochrony stosowanych oznaczeń wynikającej z przepisów u.z.n.k. przysługują do nich prawa podmiotowe. Gdyby tak było, niezgłoszone w celu uzyskania prawa ochronnego na znak towarowy oznaczenia przedsiębiorstwa lub towarów i usług można byłoby uznać za przedmiot praw osobistych lub majątkowych w rozumieniu art. $132^{1} \S 1$ pkt 1 p.w.p. W takim przypadku ofiara trademark trollingu zarówno w sprzeciwie, jak i we wniosku o unieważnienie prawa ochronnego udzielonego trollowi mogłaby skutecznie powołać się nie tylko na naruszenie prawa do firmy, imienia, nazwiska, innych dóbr osobistych oraz praw własności intelektualnej, lecz również na fakt wcześniejszego korzystania w obrocie z niezgłoszonych do Urzędu Patentowego oznaczeń towarów, usług lub przedsiębiorstwa. Kwestia ta stanowi przedmiot rozbieżnych ocen przedstawicieli nauki prawa.

Prezentowany jest pogląd, że udzielenie oznaczeniu przedsiębiorstwa oraz oznaczeniu towarów lub usług ochrony prawnej w ramach deliktowego reżimu u.z.n.k. nie może być zrównane z wykreowaniem nowego prawa podmiotowego przysługującego $\mathrm{w}$ stosunku do tych oznaczen ${ }^{34}$. W celu jego uzasadnienia podkreśla się, że odmienna ocena prowadziłaby de facto do przyznania korzystajaccym z niezarejestrowanego oznaczenia prawa do wyłacznego używania znaku towarowego, mimo braku zgłoszenia tego znaku do Urzędu Patentowego i wydania ostatecznej, konstytutywnej decyzji o udzieleniu prawa ochronnego ${ }^{35}$. Wskazuje się ponadto na obowiazywanie w polskim prawie zasady numerus clausus praw podmiotowych, do której przełamania doszłoby w przypadku przyjęcia odmiennego poglądu ${ }^{36}$.

Inne stanowisko zakłada, że wobec udzielenia niezarejestrowanym oznaczeniom ochrony na podstawie równoległego względem p.w.p. reżimu u.z.n.k. możliwe jest wyodrębnienie prawa majątkowego, przesłankę powstania którego stanowi używanie oznaczenia w obrocie, natomiast treść pozwala uniemożliwić innym podmiotom wykorzystywanie w działalności gospodarczej podobnych oznaczeń dla podobnych towarów lub usług $^{37}$. Jedną z różnic między tym prawem a prawem ochronnym na

${ }^{34}$ R. Skubisz, M. Mazurek: Względne podstawy..., s. 826-830.

${ }^{35}$ Ibidem.

${ }^{36}$ Ibidem.

${ }^{37}$ Zob. m.in. M. Trzebiatowski: Prawo do niezarejestrowanego znaku towarowego jako sktadnik przedsiębiorstwa (krytyka wyroków WSA i NSA w Warszawie). „Rejent” 2009, s. 100-123; Idem: Prawo ochronne na znak towarowy. W: „System Prawa Prywatnego". T. 14B: Prawo własności przemystowej. Red. R. Skubisz..., s. 896-899. Stanowisko to popieraja M. Witkowska, A. Michalak: Komentarz do art. $132^{1}$ p.w.p...., 
znak towarowy stanowiłaby zaś możliwość amortyzacji prawa ochronnego na znak towarowy na podstawie przepisów ustaw o podatkach dochodowych $^{38}$.

Należy zauważyć, że na podstawie art. 4 ust. 4 lit. b dyrektywy 2008/95/WE państwa członkowskie mogły wprowadzić przesłankę odmowy udzielenia prawa ochronnego na znak towarowy lub jego unieważnienia, dotycząca kolizji między znakiem zgłoszonym a wcześniejszym oznaczeniem niezarejestrowanym, jeżeli na podstawie przepisów prawa krajowego oznaczenie niezarejestrowane uprawnia korzystajacy z niego podmiot do zakazania używania przez inne podmioty późniejszego znaku towarowego. Nowa dyrektywa 2015/2436 w art. 5 ust. 4 lit. a zawiera podobną normę prawną i umożliwia wprowadzenie opartej na niej względnej przeszkody uzyskania prawa ochronnego na znak towarowy. $\mathrm{Z}$ uwagi na występujące $\mathrm{w}$ nauce prawa wątpliwości dotyczące charakteru praw do niezarejestrowanych oznaczeń pożądane jest, aby przedmiotowa kwestia została wyraźnie rozstrzygnięta przez ustawodawcę - jest ona istotna również dla ochrony przed trademark trollingiem.

Jednak nawet $\mathrm{w}$ przypadku przyjęcia stanowiska, że w sprzeciwie lub wniosku o unieważnienie prawa ochronnego na znak towarowy nie istnieje możliwość skutecznego powołania się na uprzednie korzystanie w obrocie z niezarejestrowanego oznaczenia przedsiębiorca będący ofiarą trademark trollingu może wystapić wobec trolla z roszczeniami, o których mowa w art. 18 u.z.n.k., w tym z roszczeniem o zaniechanie dalszych działań niedozwolonych przez podmiot, któremu formalnie przysługuje prawo ochronne na znak towarowy. Realizacja takiego roszczenia mogłaby doprowadzić do stanu, w którym trademark troll uprawniony z tytułu prawa ochronnego na znak towarowy nie może w praktyce korzystać ze znaku. Wyrok sądu powszechnego nie może jednak unieważnić samego prawa ochronnego - w tym celu konieczne byłoby wystapienie $\mathrm{z}$ wnioskiem o jego unieważnienie do UPRP. W orzecznictwie sądowym ukształtował się pogląd, który obecnie można by uznać za przeważaja$\mathrm{cy}^{39}$, zgodnie z którym udzielenie prawa ochronnego nie wyłącza materialnoprawnej ochrony oznaczeń wynikającej z przepisów u.z.n.k. Kwe-

nb 4 oraz J. Kępiński, M. Kępiński, I.B. Nestoruk: Oznaczenia odróżniajace. W: „System Prawa Prywatnego”. T. 15: Prawo konkurencji. Red. M. Kępiński. Warszawa 2014 , s. 206-207.

${ }^{38}$ M. Trzebiatowski: Prawo ochronne..., s. 896-897.

${ }^{39}$ Zob. w tym kontekście m.in. M. Kępiński: Komentarz do art. 5 u.z.n.k. W: Ustawa o zwalczaniu nieuczciwej konkurencji. Komentarz. Red. J. Szwaja. 2016. LEGALIS, nb 39-47 oraz orzeczenia Sądu Najwyższego: postanowienie z dnia 30 września 1994 r., III CZP 109/94. OSNC 1995/1, poz. 18; wyrok z dnia 23 marca 2002 r., III CKN 777/00. OSNC 2003/3, poz. 40 czy wyrok z dnia 23 października 2008 r., V CSK 109/08. LEX nr 479328. 
stia ta wciąż stanowi jednak przedmiot rozbieżnych ocen $\mathrm{w}$ doktrynie. Niektórzy jej przedstawiciele podaja w wątpliwość zasadność stanowiska, w myśl którego kolizje między podmiotowymi prawami wyłącznymi do znaków towarowych wynikajacymi z decyzji UPRP a podlegajacymi ochronie deliktowej oznaczeniami używanymi w obrocie powinny być rozstrzygane wyłącznie z użyciem kryterium pierwszeństwa korzystania ze znaku ${ }^{40}$. Warto mieć na względzie, że wskazany wyżej dominujący w judykaturze pogląd może zostać zakwestionowany z perspektywy orzecznictwa TSUE, w którym przyjęto założenie, że prawna ocena sposobu korzystania z zarejestrowanego znaku towarowego powinna być dokonywana wyłącznie na podstawie przepisów prawa znaków towarowych ${ }^{41}$.

Problem co do zakresu i sposobu ochrony niezarejestrowanych oznaczeń nie występuje w przypadku znaków towarowych powszechnie znanych w rozumieniu art. $132^{1}$ ust. 1 pkt 5 p.w.p. ${ }^{42}$ Szczególna ochrona tych znaków przejawia się $\mathrm{w}$ tym kontekście w możliwości wystąpienia ze sprzeciwem lub wnioskiem o unieważnienie kolidującego prawa ochronnego na znak towarowy, nawet pomimo braku zarejestrowania w UPRP znaku powszechnie znanego. W odróżnieniu od innych znaków niezarejestrowanych, okoliczność ta wynika wprost z przepisów ustawy, a tym samym nie rodzi wątpliwości ${ }^{43}$.

40 Zaproponowano, by korzystanie $\mathrm{z}$ formalnie chronionego znaku towarowego kolidującego z wcześniejszym niezarejestrowanym oznaczeniem kwalifikować jako czyn nieuczciwej konkurencji wtedy, gdy w stanie faktycznym sprawy zachodziły dodatkowo przesłanki pozwalające uznać takie zachowanie za sprzeczne $\mathrm{z}$ dobrymi obyczajami w rozumieniu art. 3 ust. 1 u.z.n.k. Zob. m.in. M. Żuraw: Kolizje prawa ochronnego na znak towarowy i niezarejestrowanego oznaczenia pochodzenia towaru. ,Zeszyty Naukowe Uniwersytetu Jagiellońskiego. Prace z Prawa Własności Intelektualnej” 2006, z. 95, s. 204.

${ }^{41}$ Zob. Ł. Żelechowski: Kolizja prawa ochronnego na znak towarowy $i$ reżimu ochrony oznaczeń odróżniajacych na podstawie ustawy o zwalczaniu nieuczciwej konkurencji - perspektywa w świetle orzeczenia Trybunatu Sprawiedliwości. W: „Experientia docet”..., s. 778-789 w kontekście wyroku TSUE z dnia 19 września 2013 r. w sprawie C-661/11 Martin Y Paz Diffusion SA v. David Depuydt i Fabriek van Maroquinerie Gauquie NV. ECLI:EU:C:2013:577.

${ }_{42}$ Zgodnie zaś z art. 301 p.w.p., „uprawniony do znaku towarowego powszechnie znanego na terytorium Rzeczypospolitej Polskiej może żądać, z zastrzeżeniem art. 165 ust. 1 pkt 3, zaprzestania używania znaku identycznego lub podobnego w odniesieniu do towarów identycznych lub podobnych, gdy używanie takie może wprowadzać odbiorców w błąd co do pochodzenia towaru". Odnośnie do wykładni pojęcia znaku powszechnie znanego zob. m.in. M. Kubiak: Komentarz do art. 301 ustawy Prawo własności przemysłowej. W: Prawo własności przemysłowej. Komentarz. Red. A. Michalak..., nb 1-3.

${ }^{43}$ Jednocześnie należy pamiętać o różnicy między znakami powszechnie znanymi a znakami renomowanymi - te drugie podlegają szczególnej ochronie tylko w przypadku ich zarejestrowania. Zob. więcej M. Witkowska, A. Michalak: Komentarz do art. $132^{1}$ p.w.p...., nb 52-73. 


\section{Inne formy ochrony prawnej przed trademark trollingiem}

Do tej pory omówione zostały skrótowo instrumenty prawne mogace zapobiec uzyskaniu lub utrzymaniu prawa ochronnego na znak towarowy przez podmiot stosujacy trademark trolling. Niemniej jednak na skutek bierności przedsiębiorcy będącego ofiarą trollingu (związanej chociażby z brakiem wiedzy o tym, że używane przez niego oznaczenia zostały zgłoszone przez osobę trzecia) troll może uzyskać formalne podstawy do kierowania roszczeń względem przedsiębiorcy kontynuującego używanie dotychczasowych oznaczeń. Należy w tym miejscu przywołać art. 296 ust. 1 p.w.p., w którym wśród roszczeń przysługujacych z tytułu naruszenia prawa ochronnego na znak towarowy wymieniono roszczenie o zaniechanie naruszania prawa ochronnego oraz wydanie bezpodstawnie uzyskanych korzyści, a w przypadku zawinionego naruszenia również roszczenie o naprawienie szkody - bądź na zasadach ogólnych, bądź przez zapłatę sumy pieniężnej odpowiadającej opłacie licencyjnej lub zapłatę innego stosownego wynagrodzenia. W przypadku wytoczenia przez podmiot stosujacy trademark trolling takiego powództwa zasadne byłoby podniesienie $\mathrm{w}$ toku procesu przez poszkodowanego trollingiem przedsiębiorcę zarzutu nadużycia przez powoda praw podmiotowych. Przypomnijmy, że przedmiotem niniejszej analizy sa stany faktyczne, w których powód dochodzi roszczeń w sytuacji, w której uzyskane przez niego prawo ochronne kwalifikuje się do unieważnienia przez Urząd Patentowy ze względu na jego uzyskanie w złej wierze. W tak wyraźnych przypadkach prawidłowe wydaje się zastosowanie przez sąd art. 5 Kodeksu cywilnego ${ }^{44}$ i oddalenie powództwa ${ }^{45}$.

Jednocześnie należy podkreślić, że oddalenie powództwa o zapłatę i zaprzestanie naruszeń z oczywistych względów nie doprowadzi do unieważnienia prawa ochronnego na znak towarowy. Pokrzywdzony trollingiem przedsiębiorca będzie musiał złożyć $\mathrm{w}$ tym przedmiocie wniosek do UPRP, przy czym jego skuteczność będzie, rzecz jasna, uzależniona od skutecznego wykazania złej wiary (lub wystąienia innej bezwzględnej lub względnej przesłanki odmowy udzielenia prawa ochronnego) po stronie podmiotu uprawnionego.

${ }^{44}$ Ustawa z dnia 23 kwietnia 1964 r. - Kodeks cywilny. Tekst jedn. Dz.U. 2017, poz. 459 ze zm. [dalej: k.c.].

${ }^{45}$ Podobnie M. Kubiak: Komentarz do art. 258 ustawy Prawo własności przemysłowej. W: Prawo własności przemysłowej. Komentarz. Red. A. Michalak..., nb 7 - w kontekście patent trollingu oraz Sąd Okręgowy w Lublinie w wyroku z dnia 31 lipca 2017 r., I C 758/16, http://orzeczenia.lublin.so.gov.pl — w kontekście copyright trollingu. 
Warto podkreślić, że polski ustawodawca nie zdecydował się na powielenie funkcjonującego w ramach systemu znaków towarowych Unii Europejskiej rozwiązania umożliwiającego pozwanemu zgłoszenie powództwa wzajemnego o stwierdzenie wygaśnięcia lub unieważnienie prawa ochronnego. Możliwość skorzystania z takiego środka ochrony prawnej zachodzi w toku rozpoznawania pozwu opartego na twierdzeniu o naruszeniu prawa ochronnego na znak towarowy Unii Europejskiej ${ }^{46}$. Tego rodzaju sprawy rozpoznawane sa w Polsce przez Sąd Okręgowy w Warszawie, XXII Wydział Unijnych Znaków Towarowych i Wzorów Wspólnotowych. W tym konkretnym przypadku o stwierdzeniu wygaśnięcia albo o unieważnieniu prawa ochronnego decyduje SO w Warszawie, a nie Urząd Unii Europejskiej ds. Własności Intelektualnej (EUIPO). Jak wcześniej wskazano, takiej możliwości nie przewidziano jednak w odniesieniu do krajowych znaków towarowych, a zatem kompetencję do unieważnienia krajowego znaku towarowego uzyskanego przez podmiot stosujący trademark trolling posiada wyłącznie UPRP.

Warto jednocześnie pamiętać o niektórych ograniczeniach prawa ochronnego na znak towarowy, które moga zapewnić przedsiębiorcom pewien zakres ochrony przed trademark trollingiem. Chodzi zwłaszcza o prawa tzw. używacza uprzedniego uregulowane w art. 160 ust. 1 i 2 p.w.p., a więc prawa przedsiębiorcy, który prowadzi lokalną działalność gospodarczą w niewielkim rozmiarze oraz używa w dobrej wierze oznaczenia, które następnie zostanie przedmiotem prawa ochronnego na znak towarowy ustanowionego na rzecz innego przedsiębiorcy. Używacz uprzedni, na podstawie przywołanego przepisu, jest uprawniony do dalszego bezpłatnego używania tego oznaczenia, w zakresie nie większym niż dotychczasowo ${ }^{47}$. Ponadto, prawo ochronne na znak towarowy nie uprawnia do zakazywania osobom fizycznym korzystania w obrocie $\mathrm{z}$ ich nazwisk lub adresów ${ }^{48}$.

${ }^{46}$ Zob. art. 128 rozporządzenia nr 2017/1001 w sprawie znaku towarowego Unii Europejskiej.

${ }_{47}$ Warto dodać, że prawo używacza uprzedniego może zostać, na jego wniosek, wpisane przez Urząd Patentowy do rejestru znaków towarowych. Stanowi również przedmiot obrotu, przy czym może zostać przeniesione na inną osobę tylko wraz z przedsiębiorstwem. Zob. szerzej J. Sitko: Komentarz do art. 160 p.w.p. W: T. Demendecki, A. Niewęgłowski, J.J. Sitko, J. Szczotka, G. Tylec: Prawo własności przemystowej. Warszawa 2015.

${ }^{48}$ Zob. art. 156 ust. 1 pkt 1 p.w.p. 


\section{Wnioski końcowe}

Współcześni przedsiębiorcy, narażeni na stosowanie trademark trollingu, dysponują różnorodnymi środkami prawnymi mogącymi służyć przeciwdziałaniu tymże praktykom. Wydaje się, że szczególnie podatni na trademark trolling są drobni przedsiębiorcy, którzy z uwagi na brak dostatecznej świadomości prawnej mogą nie dysponować wiedzą na temat tego, jak skutecznie chronić swoją własność intelektualna. Taką wiedzą dysponuja zaś trolle, w związku z czym metody ich działania sprowadzaja się przede wszystkim do prób skłonienia ofiary do zawarcia niekorzystnej ugody bądź umowy licencyjnej. Unikają zaś procesów sądowych, w których narażeni są na porażkę i obowiązek zwrotu kosztów postępowania. Trzeba zauważyć, że w praktyce trademark trolling często bywa wymierzany również w dużych przedsiębiorców, którzy — w zamyśle trolla - byliby skłonni do zawarcia porozumienia w celu odblokowania możliwości funkcjonowania pod dotychczas stosowanymi oznaczeniami na nowych rynkach ${ }^{49}$.

Wydaje się, że najistotniejsze dla wyeliminowania praktyk opisywanych jako trademark trolling sa kampanie informacyjne zmierzajace do upowszechnienia wśród przedsiębiorców (zwłaszcza małych) znajomości uprawnień, w które wyposażają ich przepisy regulujące problematykę znaków towarowych, a także ochrony prawa do firmy oraz do innych oznaczeń. Najlepszym sposobem uniknięcia „spotkania” z trademark trollem jest bowiem skrupulatne zgłaszanie własnych znaków towarowych w celu uzyskania praw ochronnych, a także bieżące monitorowanie udostępnianych bezpłatnie w wersji elektronicznej „Biuletynu Urzędu Patentowego” oraz „Biuletynu Znaków Towarowych Unii Europejskiej”, w których publikowane są wszystkie zgłoszenia znaków towarowych. Jeżeli jednak doszło już do uzyskania przez trademark trolla ochrony na podstawie decyzji UPRP lub EUIPO, to konieczne jest skorzystanie z następczych środków ochrony prawnej, obejmujących w szczególności wniosek o unieważnienie prawa ochronnego. Warto jednocześnie pamiętać o ochronie przysługującej na podstawie przepisów u.z.n.k., jednak $\mathrm{z}$ zastrzeżeniem wyrażanych $\mathrm{w}$ nauce prawa wątpliwości dotyczacych wzajemnych relacji między normami tej ustawy a prawem znaków towarowych.

Analizując zaś ewentualne możliwości zmian legislacyjnych, które ułatwiłyby ochronę przed trademark trollingiem, należy wyjaśnić, że

${ }^{49}$ Chodzi zwłaszcza o przypadki tzw. trademark squattingu, których kilka przywołuje i szerzej opisuje M. Ryba: Zjawisko trademark trollingu..., s. 118-122. 
zgodnie z zastosowanym przez unijnego prawodawcę mechanizmem harmonizacji przepisów dotyczacych krajowych znaków towarowych, przewidziany w dyrektywie 2015/2436 katalog podstaw odmowy rejestracji oraz podstaw unieważnienia prawa ochronnego na znak towarowy ma charakter wyczerpujacy. Innymi słowy, ustawodawcy krajowi, poza wyraźnie wskazanymi w dyrektywie przypadkami, nie dysponują swobodą w kształtowaniu przesłanek odmowy rejestracji znaków towarowych lub unieważnienia udzielonych na nie praw ochronnych ${ }^{50}$. To podejście ilustruje motyw 14. dyrektywy 2015/2436, zgodnie z którym „Podstawy odmowy rejestracji lub unieważnienia odnoszace się do samego znaku towarowego, w tym brak charakteru odróżniającego, lub dotyczace kolizji pomiędzy znakiem towarowym a wcześniejszymi prawami, powinny być wymienione w sposób wyczerpujący, nawet jeżeli niektóre z tych podstaw mają charakter opcjonalny dla państw członkowskich i umożliwiają im utrzymanie tych podstaw w swoich przepisach lub ich wprowadzenie do nich". Tym samym w celu rozszerzenia ochrony przed trademark trollingiem można postulować skorzystanie przez ustawodawcę krajowego z możliwości wyraźnego wprowadzenia względnej przeszkody uzyskania prawa ochronnego na znak towarowy, dotyczącej kolizji zgłaszanego oznaczenia $\mathrm{z}$ używanymi uprzednio $\mathrm{w}$ obrocie oznaczeniami niezarejestrowanymi, na co pozwala art. 5 ust. 4 lit. a dyrektywy 2015/2436. Ponadto, w celu utrudnienia praktyk klasyfikowanych jako trademark squatting, ustawodawcy krajowi mogą przewidzieć, że względna przeszkodę odmowy udzielenia prawa ochronnego na znak towarowy stanowiła będzie możliwość wprowadzenia w błąd w związku z istnieniem wcześniejszego znaku towarowego chronionego w innym kraju, pod warunkiem że $\mathrm{w}$ dacie zgłoszenia zgłaszajacy działał w złej wierze ${ }^{51}$.

${ }_{50}$ Zob. m.in. wyrok Trybunału Sprawiedliwości Unii Europejskiej z dnia 27 czerwca 2013 r., C-320/12. Malaysia Dairy Industries Pte. Ltd v. Ankenævnet for Patenter og Varemærker. ECLI:EU:C:2013:435, pkt. 41-42.

${ }_{51}$ Artykuł 5 ust. 4 lit. c dyrektywy 2015/2436. 



\title{
Odpowiedzialność za naruszenie dóbr osobistych osób nieletnich z wykorzystaniem portali społecznościowych w ramach parental trollingu
}

\begin{abstract}
Parental trolling is a dangerous practice against children. It makes it possible to make ridiculous and derogatory pictures of children on social networks. Low legal awareness and social exhibitionism cause that legal guardians often do not realize that their actions may violate the personal rights of the child and, consequently, may result in legal consequences.

The sense of parental authority sometimes goes so far that the child in the eyes of parents decreases to the rank of a thing over which one has complete power. Publishing nude photos of two or three-year-old children who play naked in the sandbox or run in the garden is becoming a more common practice. The most dangerous phenomenon accompanying parental trolling is social acceptance.

Posting photos or entries that harm the good name of the person concerned may constitute a violation of personal rights. Personal rights are subject to civil law protection, regardless of other legal regulations. A child has not full legal capacity so can not dispose of his own rights. The child's guardians have the responsibility to look after a good child's image. Although in the light of law, parents or legal guardians consent to the dissemination of the image of a child, this does not mean that the child's personal rights can not be violated.
\end{abstract}

Keywords: parental trolling, personal rights, minors, social media

\footnotetext{
* Mgr, Uniwersytet Śląski w Katowicach.
} 


\section{Pojęcie parental trollingu}

Jak wynika z analizy badań przeprowadzonych przez agencję badawczą Kantar TNS Polska S.A., ponad 90\% rodziców poczuwa się do odpowiedzialności za bezpieczeństwo swoich dzieci w Internecie ${ }^{1}$. Głównymi rodzajami aktywności, które są przez nich praktykowane w tym względzie, to m.in.: sprawdzanie historii przeglądarki internetowej, z której korzysta dziecko, instalowanie na sprzęcie elektronicznym oprogramowań zapewniajacych opiekę rodzicielską lub korzystanie z Internetu wspólnie z dziećmi. Wszystkie te działania mają ochronić dziecko przed niewłaściwymi treściami bądź też kontaktami z nieznajomymi, a co za tym idzie - potencjalnie niebezpiecznymi osobami. Jak słusznie zauważa A. Andrzejewska, rodzice sa pierwszymi nauczycielami dziecka i to właśnie z nimi powinno ono odkrywać świat, w tym również świat wirtualny ${ }^{2}$.

Co natomiast w sytuacji, w której rodzic ze strażnika dziecka w Internecie zmienia się $\mathrm{w}$ jego oprawcę?

Niestety, szybki rozwój mediów społecznościowych oraz wzmożony proces komputeryzacji i cyfryzacji dzisiejszego społeczeństwa nie wpłynęły pozytywnie nawet na proces kształtowania się świadomości internetowej osób dorosłych. Czynniki te doprowadziły jednak do wykształcenia się w przestrzeni wirtualnej nowego zjawiska społecznego zwanego parental trolling.

Parental trolling (lub inaczej troll parenting) to niebezpieczna praktyka realizowana przez rodziców, a wymierzona przeciwko ich dzieciom, polegająca na udostępnianiu ośmieszających i uwłaczających godności zdjęć ich pociech na portalach społecznościowych. Niska świadomość prawna oraz społeczny ekshibicjonizm powoduja, że prawni opiekunowie często nie zdają sobie sprawy z tego, że ich działanie może naruszać dobra osobiste dziecka, a co za tym idzie - może rodzić konsekwencje prawne.

Parental trolling stanowi jeden z rodzajów cyberprzemocy, wyjątkowo okrutny, ponieważ oprawca (trollem) jest rodzic wykorzystujący bezradność własnego dziecka. Przedstawiane treści ośmieszaja, a często wręcz upokarzaja prezentowane w nich dziecko. Rodzice sprowadzaja dziecko do roli narzędzia w komunikatach noszących znamiona mowy nienawiści

1 TNS: Bezpieczeństwo dzieci $w$ Internecie, raport $z$ badań jakościowych $i$ ilościowych. Warszawa 2013.

${ }^{2}$ A. Andrzejewska: Dzieci $i$ młodzież $w$ sieci zagrożen realnych $i$ wirtualnych: aspekty teoretyczne i empiryczne. Warszawa 2014, s. 32. 
lub ukazuja je w specjalnie sprowokowanych niebezpiecznych sytuacjach. Mechanizmem, który napędza trolla, czyli w tym wypadku rodzica, jest rosnąca liczba lajków, komentarzy oraz udostępnień ${ }^{3}$.

Nazwa tego zjawiska pochodzi od szerszej grupy zachowań określanych jako trollowanie. Pod pojęciem „trollowanie” rozumie się antyspołeczne zachowanie charakterystyczne dla przestrzeni internetowej, które polega na zamierzonym wywieraniu wpływu na innych użytkowników w celu ich ośmieszenia lub obrażenia (czego następstwem jest wywołanie kłótni) przez wysyłanie napastliwych, kontrowersyjnych, często nieprawdziwych przekazów czy też stosowanie różnego typu zabiegów erystycznych $^{4}$. Chociaż parental trollingu nie można zaliczyć do klasycznego trollowania, nie ulega wątpliwości, że w obu przypadkach głównym celem podejmowanych działań jest mniej lub bardziej świadome ośmieszenie drugiej osoby.

Początków troll parentingu należy poszukiwać w 2013 r., w którym to Amerykanin Greg Pembroke założył internetowy blog o nazwie Dlaczego mój syn płacze?5. W poczatkowej fazie rozwoju bloga przedstawianymi na nim treściami były zdjęcia płaczacych synów autora, opatrzone jedynie krótkimi notkami wyjaśniającymi przyczyny łez dzieci. Wraz z rozwojem blog nabrał charakteru zbiorowego dziennika internetowego, w którym rodzice z całego świata zaczęli umieszczać zdjęcia swoich podopiecznych ${ }^{6}$. Praktyka udostępniania zdjęć dzieci w kompromitujacych sytuacjach szybko zaczęła się rozpowszechniać i przedostawać do innych portali społecznościowych, takich jak Facebook czy Instagram, gdzie szybko zadomowiła się na dobre.

\section{Społeczno-psychologiczne podłoże zjawiska parental trollingu}

Aby w pełni zrozumieć parental trolling, trzeba przede wszystkim poznać społeczne uwarunkowania, dzięki którym zjawisko to powstało.

${ }^{3}$ D. Kiłoka: „Parental trolling” — rodzicu, pomyśl zanim udostęnisz, http://ocale ni.org/2016/11/27/parental-trolling/ [Data dostępu: 2 grudnia 2017 r.].

${ }^{4}$ P. Wallach: Psychologia Internetu. Poznań 2003, s. 136.

${ }^{5}$ W języku angielskim Reasons my son is crying.

${ }^{6}$ J. Flis: „Troll parenting”- mamo nie zawstydzaj mnie $w$ sieci, http://www.psycho logiainternetu.pl/534-2/ [Data dostępu: 5 grudnia 2017 r.]. 
Z całą pewnościa parental trolling rozważany przez pryzmat nauk o społeczeństwie i jego funkcjonowaniu można zaliczyć do patologii społecznych nowej generacji. Przez patologię społeczną rozumie się zjawisko społecznego zachowania się jednostek i grup oraz funkcjonowania instytucji społecznych, pozostające $\mathrm{w}$ sprzeczności $\mathrm{z}$ wartościami i zasadami akceptowanymi przez dane społeczeństwo ${ }^{7}$. Ponieważ nie ulega wątpliwości, że jedną z podstawowych wartości chronionych w naszym społeczeństwie jest integralność więzi rodzinnych budowana przez kształtowanie poczucia bezpieczeństwa i zaufania w relacji dziecko - rodzic, kwalifikacja parental trollingu jako patologii społecznej jest w pełni uzasadniona.

Powstawanie tego typu patologii nieodzownie wiąże się z wcześniej już wspomnianym rozwojem cyfryzacji i informatyzacji i jest następstwem kształtowania się nowego rodzaju społeczeństwa.

Powszechny dostęp do technologii i wykształcenie się nowych środków przepływu informacji doprowadziły do ukształtowania formacji nazwanej społeczeństwem informacyjnym bądź sieciowym. Społeczeństwo informacyjne to społeczeństwo, które posiada zarówno instrumenty techniczne, jak i prawne, ale przede wszystkim ma wiedzę, która pozwala z tych instrumentów korzystać. Nowoczesne społeczeństwo jest zatem o wiele bardziej zaangażowane w rozwój nowych technologii ${ }^{8}$ oraz w proces kształtowania nowych ścieżek komunikacji wspartych na tych technologiach. Jak wskazuje M. Castells, naturalnym następstwem takiego stanu rzeczy jest również kształtowanie się nowej kultury, kultury wirtualnej rzeczywistości, w której zdigitalizowane sieci multimedialnej komunikacji zdominowały wszystkie formy aktywności ludzkiej, tak że uczyniły wirtualność podstawowym wymiarem naszej rzeczywistości ${ }^{9}$. Przejawem tego jest niewatpliwe wzmożona aktywność społeczeństwa na portalach internetowych. Łatwość utrzymywania kontaktów, niski koszt oraz szybkość komunikacji stanowią dodatkowe atuty, dzięki którym coraz chętniej wkracza się w świat wirtualny.

Mimo licznych zalet, komunikacja internetowa posiada także wiele wad, do których bez wątpienia można zaliczyć wyższy stopień anonimowości. Rozmawiając przy użyciu komunikatora internetowego, cały tok przepływu informacji zostaje sprowadzony tylko do wymiany tekstów wiadomości, bez możliwości zobaczenia drugiej osoby, a co za tym idzie - wychwycenia jakichkolwiek mikroekspresji. Tak zbudowana sieć kontaktów, mimo że bardzo szeroka, może okazać się zawodna w budowaniu

${ }^{7}$ Patologia spoteczna. Encyklopedia powszechna PWN. Warszawa 2016.

${ }^{8}$ K. Chałubińska-Jentkiewicz: Prawo nowych technologii. Warszawa 2015, s. 58 .

${ }^{9}$ M. Castells: Społeczeństwo sieci. Warszawa 2011, s. 21. 
głębszych więzi. Narastająca w ten sposób potrzeba zamanifestowania swojej osobowości, połączona z względną łatwością kształtowania własnego wizerunku w Internecie, powoduje najczęściej wykorzystywanie mediów społecznościowych do budowy wirtualnego alter ego. Tym samym w dzisiejszych czasach kartezjańska maksyma „myślę, więc jestem” zostaje powoli zastępowana wersją bardziej odpowiednią w erze masowej

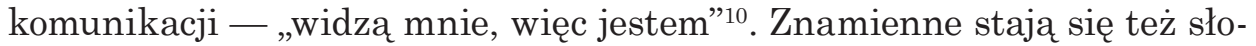
wa Z. Baumana, który zauważa: „im więcej osób może (i chce) mnie zobaczyć, tym pewniejszy jest mój w świecie pobyt [...]"11. Z tego też względu w dzisiejszych czasach obserwujemy zjawisko masowego udostępniania zdjęć, filmików bądź krótkich wpisów na portalach społecznościowych, które mają uatrakcyjnić osoby na nich przedstawione. Jak diagnozuje filozof, jednym z powodów, dla których społeczeństwo informacyjne tak chętnie zamienia sferę realna w sferę wirtualna, jest niezwykła swoboda zmiany wizerunku, która nie byłaby możliwa w życiu „poza siecia”" Internet pojmowany w taki sposób staje się narzędziem do zmiany wizerunku, a niejednokrotnie przyczyną diametralnych zmian $\mathrm{w}$ zachowaniu i tożsamości ${ }^{13}$.

Jak zatem można zauważyć, rozwój społeczeństwa informacyjnego, wzmożone wykorzystywanie technologii w procesie komunikacji, łatwość kształtowania swojego wizerunku połączone z chęcią wypromowania siebie dają bardzo żyzne podłoże do kształtowania się wszelakiego rodzaju patologii, w tym również do parental trollingu. Rodzice, udostępniając materiały, których głównym bohaterem jest ich potomstwo znajdujace się w kompromitującej sytuacji, starają się wypromować samych siebie, ubogacając w ten sposób swój profil społecznościowy. Przekonanie o komicznym charakterze prezentowanych materiałów oraz chęć jawienia się współużytkownikom portalu społecznościowego jako osoba obdarzona dystansem do siebie (a raczej do swojej rodziny) i poczuciem humoru prawie zawsze przysłaniają rodzicom zdolność prawidłowej oceny sytuacji i możliwość dostrzeżenia krzywdy niczego nieświadomego dziecka.

${ }^{10}$ K. Leksy: Ekshibicjonizm społeczny w przestrzeni wirtualnej - rozważania spoteczno-pedagogiczne. „Chowanna” 2014, T. 1 (42), s. 305.

${ }^{11}$ Z. Bauman: 44 listy ze świata ptynnej nowoczesności. Kraków 2011, s. 34-35.

12 Ibidem, s. 28-29.

${ }^{13}$ K. Leksy: Ekshibicjonizm społeczny..., s. 307. 


\section{Parental trolling a naruszenie dóbr osobistych dziecka}

\subsection{Wizerunek jako dobro osobiste dziecka}

Parental trolling jako patologia społeczna jest zjawiskiem dość nowym i jeszcze nie w pełni zbadanym. Nie ulega jednak wątpliwości, że tego typu działania moga pociągać za sobą konsekwencje prawem przewidziane.

Parental trolling w głównej mierze godzi w dobro osobiste, takie jak wizerunek prezentowanej na publikowanych materiałach osoby, tzn. dziecka. Należy zaznaczyć, że każdej osobie fizycznej, a w tym również osobie niepełnoletniej pozostającej pod opieką rodzica, przysługuje prawo do wizerunku oraz wszelkiego rodzaju narzędzia, gwarantowane przez prawo mające za zadanie jego ochronę. Ochrona ta wynika bezpośrednio z przepisów Kodeksu cywilnego ${ }^{14}$ i obejmuje wszelkie postacie wizerunku. W szczególności może tu chodzić o portrety lub fotografie powielane $\mathrm{w}$ czasopismach lub rozpowszechniane w telewizji bądź w przekazach elektronicznych ${ }^{15}$. Wizerunek jest dobrem osobistym o charakterze niezbywalnym, a co za tym idzie - nie można się go zrzec lub przenieść go na inną osobę. Od tej reguły istnieją jednak wyjątki pozwalające na rozpowszechnianie wizerunku osoby fizycznej przez osobę trzecią. Należy pamiętać, że w świetle prawa osoby fizyczne do trzynastego roku życia nie posiadaja zdolności do czynności prawnych, natomiast osobom niepełnoletnim powyżej trzynastego roku życia przysługuje tylko ograniczona zdolność do czynności prawnych. Co za tym idzie, dzieci nie moga w pełni same rozporządzać niektórymi przysługującymi im prawami i z tego właśnie względu ustawodawca powierzył rodzicom bądź innym opiekunom prawnym obowiazek dbania o dobro dziecka do czasu osiagnięcia przez nie pełnoletności.

Poza przepisami Kodeksu cywilnego, kwestie rozpowszechniania wizerunku reguluje ustawa o prawie autorskim i prawach pokrewnych ${ }^{16}$, w art. 81 stanowiąc, że wymaga ono zezwolenia osoby przedstawionej na wizerunku. Samą ochronę wizerunku w prawie autorskim reguluje art. 83, który nakazuje odpowiednie stosowanie art. 78 ust. 1 tej ustawy.

${ }^{14}$ Ustawa z dnia 23 kwietnia 1964 r. - Kodeks cywilny. Tekst jedn. Dz.U. 1964, nr 16 , poz. 93 .

${ }_{15}$ Z. Radwański, A. Olejniczak: Prawo cywilne - część ogólna. Warszawa 2015, s. 164 .

${ }_{16}$ Ustawa z dnia 4 lutego 1994 r. o prawie autorskim i prawach pokrewnych. Tekst jedn. Dz.U. 1994, nr 24, poz. 83. 
Na jego podstawie osobie uprawnionej przysługują następujące roszczenia:

- roszczenie o zaniechanie działań stwarzających zagrożenie naruszenia wizerunku;

- roszczenie o dopełnienie czynności potrzebnych do usunięcia skutków naruszenia, a w szczególności do złożenia oświadczenia o odpowiedniej treści i formie, jeśli do naruszenia doszło;

- jeżeli naruszenie było zawinione, ponadto roszczenie o zapłatę na swoją rzecz odpowiedniej sumy pieniężnej tytułem zadośćuczynienia za doznaną krzywdę lub uiszczenia odpowiedniej sumy pieniężnej na wskazany przez powoda cel społeczny ${ }^{17}$.

\subsection{Zgoda rodzica na udostępnienie wizerunku dziecka}

Patrząc przez pryzmat wykonywania władzy rodzicielskiej, zgoda na udostępnianie wizerunku dziecka powinna być udzielana przez jednego $\mathrm{z}$ rodziców. $\mathrm{Z}$ taką sytuacją będziemy mieli do czynienia zarówno wtedy, gdy władza rodzicielska należy tylko do jednego z rodziców, jak i wtedy, gdy dziecko pozostaje pod opieka obojga rodziców. Jak można wnioskować z art. $98 \S 1$ k.r.o. zd. 2 Kodeksu rodzinnego i opiekuńczego $^{18}$, każdy z rodziców może w przedstawionej sytuacji działać samodzielnie.

Stanem faktycznym wymagającym szczególnej analizy jest sytuacja, w której jedno z dwojga rodziców posiadających władzę rodzicielską sprzeciwia się rozpowszechnieniu wizerunku dziecka, podczas gdy drugie wyraża na nie zgodę. Należy tutaj w głównej mierze mieć na względzie dobro dziecka, które, do czasu osiągnięcia przez nie pełnoletności, spoczywa na rodzicach lub opiekunach prawnych, którzy sa w świetle prawa zobowiązani do dysponowania w sposób świadomy i odpowiedzialny prawami, które przysługuja dzieciom.

W przedstawionej sytuacji nie ulega watpliwości, że rodzic, który nie zezwala na rozpowszechnienie wizerunku dziecka, może zgłosić drugiemu sprzeciw, do którego ten powinien się zastosować. W przypadku niezastosowania się do sprzeciwu, gdy publikowanie wizerunku dziecka, chociażby w portalach społecznościowych, uwłaczałoby jego godności bądź też wskazywało na popełnienie przestępstwa lub uzyskanie znacz-

${ }^{17}$ M. Pazdan: Komentarz do art. 23. W: Kodeks cywilny. T. 1: Komentarz do art. 1-449. Red. K. Pietrzykowski. Warszawa 2008, s. 128-129.

18 Ustawa z dnia 25 lutego 1964 r. - Kodeks rodzinny i opiekuńczy. Tekst jedn. Dz.U. 1964, nr 9, poz. 59. 
nych korzyści majątkowych kosztem dobra dziecka, sprawą może zająć się sąd rodzinny ${ }^{19}$.

\subsection{Naruszenie dobra osobistego a naruszenie prawa do wizerunku}

Jak wskazuje się w literaturze przedmiotu ${ }^{20}$, dochodzenie prawa do ochrony wizerunku jest możliwe po spełnieniu dwóch przesłanek. Pierwszą z nich jest naruszenie dobra osobistego, natomiast druga — bezprawność działania sprawcy naruszenia.

Zdaniem Sądu Najwyższego ${ }^{21}$, obowiązujące prawo polskie nie chroni przed jakimkolwiek naruszeniem dóbr osobistych, a jedynie przed takim, które narusza jednocześnie prawo podmiotowe. Co za tym idzie, ochrony prawnej dochodzić można dopiero w sytuacji, gdy naruszona zostanie więź psychiczna osoby z jej obrazem fizycznym, który został utrwalony na wizerunku. Nie można zatem stwierdzić, że każde ustalenie czyjegoś wizerunku stanowić będzie naruszenie dobra osobistego, a jedynie takie, które narusza pewna pozytywnie oceniana przez społeczeństwo wartość.

Ponadto, zgodnie $\mathrm{z}$ art. 24 k.c., ochrona przysługuje tylko przed bezprawnym zagrożeniem lub naruszeniem dobra osobistego ${ }^{22}$. Według orzecznictwa ${ }^{23}$, dotyczy to tylko zachowań sprzecznych z normami prawnymi lub zasadami współżycia społecznego, bez względu na winę bądź też świadomość sprawcy.

Z perspektywy parental trollingu i kwestii dochodzenia swoich praw przez ofiary tego zjawiska rozróżnienie to ma ogromne znaczenie. Ze względu na specyfikę naruszeń, których dopuszczają się rodzice, polegająca na udostępnianiu kompromitujacych materiałów na temat swoich dzieci, zauważyć można, że z cała pewnością zostaje naruszone prawo podmiotowe podopiecznego, tym samym umożliwiając mu obronę swoich praw zarówno na podstawie przepisów k.c., jak i ustawy o prawie autorskim i prawach pokrewnych. Jak słusznie zauważa T. Grzeszak, środki ochrony w obu przypadkach sa co prawda bardzo podobne, ale jednak nie są identyczne ${ }^{24}$.

${ }^{19}$ N. Ryńska: O publikacji zdjęć dziecka na Facebooku decyduja oboje rodzice, http://prawo.gazetaprawna.pl/artykuly/867782,o-publikacji-zdjec-dziecka-na-facebookudecyduja-oboje-rodzice.html [Data dostępu: 23 listopada 2017 r.].

20 P. Ślęzak: Ochrona prawa do wizerunku. Katowice 2009, s. 58.

${ }^{21}$ Wyrok Sądu Najwyższego z dnia 7 listopada 2000 r., I CKN 1149/98. LEX nr 50831.

22 P. Ślęzak: Ochrona prawa..., s. 58-60.

${ }^{23}$ Wyrok Sądu Najwyższego z dnia 19 lipca 1982 r., I CR 225/82.

${ }^{24}$ T. Grzesiak, w: Prawo autorskie. W: „System Prawa Prywatnego”. T. 13: Prawo autorskie. Red. J. Barta. Warszawa 2007, s. 538 i nast. 


\subsection{Odpłatnośś}

Szczególnym przykładem parental trollingu i jedną z najbardziej okrutnych jego form jest rozpowszechnianie wizerunku dziecka w celach komercyjnych, czyli np. publikacji wizerunku dziecka na blogach modowych bądź też w reklamach. Chociaż pod względem swojej konstrukcji nie odbiega to zacznie od przykładów naruszeń w celach niekomercyjnych, słuszny wydaje się postulat, żeby okoliczności i powody, dla których opublikowano wizerunek dziecka, miały szczególne znaczenie dla sądów rozpatrujących tego typu sprawy.

Co prawda $\mathrm{w}$ polskim systemie prawnym wykorzystanie wizerunku dziecka do celów komercyjnych nie warunkuje powstania innego rodzaju odpowiedzialności ${ }^{25}$, np. karnej, jednak kierując się zasadą słuszności, należałoby stwierdzić, że sąy powinny podchodzić do tego typu spraw z należytą surowością.

\subsection{Kwestie procesowe}

Kwestia problematyczna jawiąca się na gruncie prawa procesowego jest młody wiek osób poszkodowanych w wyniku działań troll parentingu, który skutkuje ich brakiem zdolności do czynności procesowych. Co do zasady uznaje się, że w procesie dziecko reprezentowane jest przez swoich rodziców, jeśli pozostaje ono pod ich opieka rodzicielska. Umocowanie to obejmuje całokształt praw dziecka ${ }^{26}$, z wyjątkiem tych, co do których istnieje zakaz ustawowy.

Wyłączenie przedstawicielstwa rodziców ze względu na możliwość sprzeczności interesów ustawa - Kodeks rodzinny i opiekuńczy reguluje w art. $98 \S 2 \mathrm{w}$ dwóch przypadkach:

- przy czynnościach prawnych między dziećmi pozostajacymi pod ich władzą rodzicielską oraz

- przy czynnościach prawnych między dzieckiem a jednym z rodziców lub jego małżonkiem.

Postępowania z zakresu naruszeń dóbr osobistych i prawa do wizerunku $\mathrm{w}$ ramach parental trollingu $\mathrm{z}$ cała pewnościa charakteryzować się będą sprzecznością interesów między dziećmi a ich rodzicami. Z jednej strony mamy interes dziecka, którym jest ochrona własnych praw do rozporządzania swoim wizerunkiem, a z drugiej rodzica, który jako

${ }^{25}$ N. Ryńska: O publikacji zdjęć dziecka na Facebooku decyduja oboje rodzice...

26 J. Gajda: Komentarz do art. 98 k.r.o. W: Kodeks rodzinny i opiekuńczy. Komentarz. Red. K. Pietrzykowski. Warszawa 2017, s. 298. 
sprawca naruszenia dążyć będzie do uniknięcia odpowiedzialności cywilnej. W tego typu sytuacjach dziecko reprezentowane jest przez kuratora, ustanowionego przez sąd opiekuńczy na wniosek sądu rozpoznajacego sprawę.

Trudności może jednak sprawić sama praktyka stosowania tych przepisów, gdyż dziecko, jako osoba nieposiadająca zdolności do czynności procesowej, nie jest również zdolne do samodzielnego wniesienia powództwa przeciwko swoim rodzicom. Pozew taki musiałby zostać zatem wytoczony przez odpowiednią instytucję, jak np. Rzecznika Praw Dziecka bądź prokuratora. W rzeczywistości jednak takie sytuacje nie mają miejsca z oczywistego powodu, jakim jest brak świadomości dziecka o przysługujących mu środkach prawnych. Jednakże, na mocy art. 70 $\S 2$ k.p.c. ${ }^{27}$, sąd może tymczasowo dopuścić do czynności stronę niemająca zdolności procesowej albo osobę, która nie posiada należytego ustawowego umocowania - z zastrzeżeniem, że przed upływem wyznaczonego terminu braki będą uzupełnione, a czynność zostanie zatwierdzona przez osobę odpowiednio do tego powołaną ${ }^{28}$.

Należy jednak zauważyć, że omawiane typy roszczeń mają charakter niemajątkowy, a co za tym idzie - nie ulegają przedawnieniu ${ }^{29}$. Nic nie stoi więc na przeszkodzie, aby dochodzić ochrony dóbr osobistych po uzyskaniu pełnoletności, a tym samym pełnej zdolności do czynności procesowych.

\section{Wnioski}

Parental trolling, choć jest zjawiskiem stosunkowo nowym i jeszcze w pełni niezbadanym, jawi się jako niezwykle niebezpieczne i szkodliwe, głównie ze względu na to, w jakie wartości najmocniej uderza. Delikatne relacje na linii rodzic - dziecko stanowią w naszym społeczeństwie jeden $\mathrm{z}$ fundamentów prawidłowo funkcjonującej rodziny. Działania, które moga zostać zaliczone do tych, które parental trolling obejmuje swym zakresem, niewątpliwie naruszają tę szczególną więź, niszcząc wzajemne zaufanie. Brak szacunku dla prywatności najmłodszych, chęć zaistnie-

${ }^{27}$ Ustawa z dnia 17 listopada 1964 r. — Kodeks postępowania cywilnego. Tekst jedn. Dz.U. 1964, nr 43, poz. 296.

${ }^{28}$ H. Dolecki: Postępowanie cywilne - zarys wyktadu. Warszawa 2015, s. 96.

${ }^{29}$ P. Machnikowski: Komentarz do art. 117 k.c. W: Kodeks cywilny. Komentarz. Red. E. Gniewek. Warszawa 2017, s. 299. 
nia w Internecie oraz niska świadomość prawna młodych rodziców korzystajacych na co dzień z dorobku techniki, niestety, stanowią podstawę namnażania niebezpiecznych dla dobra dziecka zachowań w Internecie.

Zjawisko to może rodzić następstwa prawne w postaci pociąnięcia do odpowiedzialności cywilnej rodzica z powodu naruszenia dobra osobistego, jakim jest wizerunek dziecka. Osoba przedstawiona na wizerunku, czyli w tym wypadku dziecko, może dochodzić ochrony swoich praw, zgodnie z przepisami prawa cywilnego i prawa autorskiego. Ochronę wizerunku reguluje art. 83 ustawy o prawie autorskim i prawach pokrewnych, odsyłający do art. 78 ust. 1, w którym wymienione są roszczenia, jakich dochodzić może osoba, której wizerunek został rozpowszechniony. Ponadto, udostępnienie kompromitujących materiałów godzi w prawa podmiotowe dziecka. Oznacza to, że może tutaj znaleźć również zastosowanie art. 24 k.c., wymieniający rodzaje uprawnień przysługujących osobie, której dobro osobiste zostaje zagrożone cudzym, bezprawnym działaniem. Niestety, zgodnie z przepisami Kodeksu rodzinnego i opiekuńczego, każdy z rodziców posiadających władzę rodzicielską może samodzielnie wyrazić zgodę na udostępnienie wizerunku dziecka. Stanowi to znaczne utrudnienie, jeżeli chodzi o przeciwdziałanie omawianemu zjawisku. Ze względu na utrudnienia procesowe, które może napotkać osoba pokrzywdzona w drodze do dochodzenia swoich praw, ustawodawca wprowadza możliwość dochodzenia praw niemajątkowych przed sadem dopiero po uzyskaniu przez nią pełnoletności. 



\title{
Środki przeciwdziałania nadużyciu idei ochrony patentowej przez tak zwanych trolli patentowych w prawie unijnym
}

\begin{abstract}
The phenomenon of patent trolling is a distortion of the idea underlying patent protection. The effects of the so-called patent trolls are, inter alia, the inhibition of technological development, limiting innovation and technology transfer, and restricting access to these technologies for consumers on the market. Negative effects also manifest themselves in showing deficiencies in the patent protection system, lack of trust in this system and reduction of investments in the field of research \& development. All these effects are the negation of what was the foundation of the introduction of patent protection.

The aim of the author is to analyze the existing regulations of European Union law in terms of possible protection measures against the so-called patent trolls. In particular, the provisions of Directive 2004/48/EC of the European Parliament and of the Council of 29 April 2004 on the enforcement of intellectual property rights will be discussed. The possibilities of counteracting the phenomenon of patent trolling in court proceedings before the Unified Patent Court provided for in the Agreement on the Unified Patent Court (2013/C 175/01), being part of the so-called the system of the European Unitary Patent. In addition to the analysis of regulations, the judgments of the European courts regarding this issue will also be presented. The analysis of EU regulations and jurisprudence is supposed to be an attempt to answer the question whether current regulations are sufficient for the threat of patent trolling in Europe.
\end{abstract}

Keywords: patent trolling, PAE, idea of patent protection, enforcement directive, Unitary Patent Court, Huawei v ZTE

\footnotetext{
* Mgr, Uniwersytet Ślaski w Katowicach.
} 


\section{Wprowadzenie}

Stownik języka polskiego PWN definiuje trolla jako istotę zamieszkująca górskie jaskinie, o niemiłym usposobieniu, wywodząca się z mitologii skandynawskiej ${ }^{1}$. Można zadać pytanie, co postać z mitologii krajów nordyckich ma wspólnego z systemem ochrony patentowej. Odpowiedzi na to pytanie należy poszukiwać w Stanach Zjednoczonych Ameryki Północnej, ponieważ to właśnie tam po raz pierwszy zaczęto łączyć baśniowego stwora z ochrona patentowa ${ }^{2}$. Pojęcie „troll patentowy” upowszechniło się na gruncie amerykańskim w połowie lat dziewięćdziesiątych XX w., po emisji filmu instruktażowego dla wynalazców, zatytułowanego The Patents Video. Film ten prezentował historię osoby zmuszonej do nabycia licencji od uprawionego z patentu, który to uprawniony został przedstawiony właśnie jako mitologiczny troll ${ }^{3}$.

Początkowo rozumienie trolla patentowego było nieco inne niż obecnie, natomiast podmioty, których model biznesowy polega na „wykorzystywaniu praw wyłacznych jedynie w celu przymuszania innych przedsiębiorców do zawierania umów licencyjnych”, pojawiły się w ciągu następnych lat ${ }^{4}$. Z czasem okazało się, że problem ten jest tak poważny, że sam Prezydent Stanów Zjednoczonych Barack Obama oficjalnie odniósł się do niego, decydując się podjąć walkę z trollami patentowymi ${ }^{5}$. Przez wiele lat trolling patentowy był głównym tematem badań akademickich, przeważał jednak pogląd, że jest to zjawisko prawie wyłącznie

${ }^{1}$ Stownik języka polskiego PWN, https://sjp.pwn.pl/sjp/troll;2578748 [Data dostępu: 31 grudnia 2017 r.].

${ }_{2}^{2}$ M. Kruk: Trolle patentowe - zmora systemu ochrony patentowej $w$ USA. „Kwartalnik Urzędu Patentowego RP” 2013, nr 2, s. 17.

${ }^{3}$ Ibidem. Fragment filmu The Patents Video, zawierajacy sceny ze wspomnianym trollem, https://www.youtube.com/watch?v=lOGoZFzHkhs [Data dostępu: 31 grudnia 2017 r.]. We wspomnianym fragmencie pojawia się także hasło „Beware of the Patent Troll" (ang. wystrzegaj się trolla patentowego).

${ }^{4}$ Ibidem.

${ }^{5}$ Obama goes troll-hunting. „The Economist” 8.06.2013, https://www.economist.com/ news/business/21579011-president-proposes-new-round-intellectual-property-reform-ob ama-goes-troll-hunting [Data dostępu: 31 grudnia 2017 r.]; S. Gustin: Viewpoint: Obama's 'Patent Troll' Reform: Why Everyone Should Car. „Time” 8.06.2013, http://business. time.com/2013/06/08/viewpoint-obamas-patent-troll-reform-why-everyone-should-care/ [Data dostępu: 31 grudnia 2017 r.]. Szerokie badania dotyczące skali „działalności” sadowej trolli patentowych w Stanach Zjednoczonych przeprowadziła C. Chien: Patent Trolls by the Numbers. „Santa Clara University Legal Studies Research Paper No. 08-13” 2013, https://papers.ssrn.com/sol3/papers.cfm?abstract_id=2233041.\#\# [Data dostępu: 31 grudnia 2017 r.]. 
występujące w Stanach Zjednoczonych ${ }^{6}$. Ostatnie badania wskazuja jednak, że zjawisko to, chociaż w mniejszym zakresie niż w Stanach Zjednoczonych, występuje również na kontynencie europejskim?

W literaturze pojawiło się także kilka opracowań stanowiących próbę porównania skali zjawiska trollingu patentowego w Stanach Zjednoczonych i na Starym Kontynencie. Skupiaja się one głównie na fakcie „rozczłonkowania” systemu patentowego w Europie w porównaniu z federalizacją tegoż systemu w Stanach Zjednoczonych ${ }^{8}$. Celem niniejszego artykułu jest natomiast próba odpowiedzi na pytanie, czy wśród regulacji prawa Unii Europejskiej znajdują się wystarczające środki przeciwdziałania nadużyciu ochrony patentowej przez tzw. trolle patentowe. Przede wszystkim omówione zostanie samo zjawisko patent trollingu. Następnie analizie poddane zostana postanowienia dyrektywy 2004/48/WE Parlamentu Europejskiego i Rady z dnia 29 kwietnia 2004 r. w sprawie egzekwowania praw własności intelektualnej ${ }^{9}$. Pokrótce przedstawione zostana postanowienia proceduralne porozumienia w sprawie Jednolitego Sądu Patentowego ${ }^{10}$, które co prawda z formalnego punktu widzenia nie jest pochodnym prawem unijnym, jednak jest ściśle zwiąane z rozporządzeniem Parlamentu Europejskiego i Rady (UE) nr 1257/2012 z dnia 17 grudnia 2012 r. wprowadzającym wzmocnioną współpracę w dziedzinie tworzenia jednolitego systemu ochrony patentowej ${ }^{11}$. Przywołane zostanie także orzecznictwo Trybunału Sprawiedliwości UE. W celu przedstawienia obowiąujących regulacji oraz ich znaczenia dla zjawiska trollingu patentowego w niniejszym opracowaniu zastosowano metodę dogmatyczno-prawna.

${ }^{6}$ B.J. Love, Ch. Helmers, F. Gaessler, M. Ernicke: Patent Assertion Entities in Europe. In: Patent Assertion Entities and Competition Policy. Ed. D.D. Sokol. Cambridge-New York 2016, s. 104 i powołana tam literatura.

${ }^{7}$ Ibidem; Ch. Helmers, B. Love, L. McDonagh: Is There a Patent Troll in the U.K.? „Fordham Intelletctual Property, Media \& Enterntainment Law Journal” 2014, vol. 24, s. 509-554. Badania zostały przeprowadzone w Niemczech (2000-2008) oraz w Wielkiej Brytanii (2000-2013).

${ }^{8}$ Zob. m.in.: S. Fusco: Markets and Patent Enforcement: A Comparative Investigation of Non-Practicing Entities in the United States and Europe. „Michigan Telecommunications and Technology Law Review" 2014, vol. 20, no. 2, s. 439-465; A. Mayergoyz: Lessons from Europe on How to Tame U.S. Patent Trolls. „Cornell International Law Journal" 2009, vol. 42, s. 241-270.

9 Dyrektywa 2004/48/WE Parlamentu Europejskiego i Rady z dnia 29 kwietnia 2004 r. w sprawie egzekwowania praw własności intelektualnej. Dz.Urz. UE L 157, 30.04.2004, s. 45-86, Polska Edycja Specjalna: rozdział 17, T. 2, s. 32-39.

10 Porozumienie w sprawie Jednolitego Sąu Patentowego. Dz.Urz. UE C 175, 20.06.2013, s. 1-40.

${ }^{11}$ Rozporządzenie Parlamentu Europejskiego i Rady (UE) nr 1257/2012 z dnia 17 grudnia 2012 r. wprowadzające wzmocnioną współpracę w dziedzinie tworzenia jednolitego systemu ochrony patentowej. Dz.Urz. UE L 361, 31.12.2012, s. 1—8. 


\section{Idea przyznania ochrony patentowej}

Chcąc udzielić odpowiedzi na pytanie, czym jest w istocie trolling patentowy, niezbędne wydaje się przytoczenie idei, będącej podstawą całego systemu ochrony patentowej. Tradycyjnie przyznanie wynalazcy ochrony patentowej uzasadnia się naturalnym prawem wynalazcy do efektów jego wysiłków umysłowych, zapewnieniem rekompensaty za dokonanie wynalazku, stworzeniem zachęty do opracowywania nowych rozwiązań oraz ich stosowania, a także czynnikiem motywujacym do ujawnienia rozwiazania społeczeństwu ${ }^{12}$. Także Trybunał Sprawiedliwości UE w swoich orzeczeniach odniósł się do uzasadnienia ochrony patentowej, stwierdzajac, że prawo patentowe zagwarantować ma wynalazcy nagrodę za jego twórczy wysiłek, udzielając mu wyłącznego prawa do wytwarzania produktów oraz wprowadzania ich na rynek, a ponadto ma pozwolić sprzeciwiać się naruszeniom ${ }^{13}$. Wskazuje się, że idea ochrony polega na równowadze pomiędzy interesem społeczeństwa a interesem indywidualnym wynalazcy - monopol patentowy ma umożliwić uprawnionemu zwrot poniesionych na wynalazek nakładów, w tym kosztów, a równocześnie ma stanowić bodziec do dalszej pracy wynalazczej ${ }^{14}$. Monopol ten jednak jest ograniczony w czasie, co zakłada przejście ujawnionego rozwiązania do domeny publicznej ${ }^{15}$.

Podobnie w piśmiennictwie amerykańskim podkreśla się, że podstawa prawa patentowego jest wymiana quid pro quo. Wynalazca ujawnia więc wynalazek społeczeństwu, a $\mathrm{w}$ zamian otrzymuje ograniczone w czasie prawo wyłączne do stworzonego przez siebie rozwiązania ${ }^{16}$. Ujawnienie rozwiązania pozwala innym na opracowanie nowych technologii, opierając się na rozpowszechnionym już wynalazku ${ }^{17}$. Rekompen-

12 E. Traple, M. du Vall: Teorie uzasadniajace ochronę patentowa $i$ ocean jej gospodarczego znaczenia. W: Prawo patentowe. Red. E. Traple. Wyd. 2. Warszawa 2017, s. 190-197; por. także R. Skubisz: Wtasność przemysłowa $w$ systemie prawa. W: „System Prawa Prywatnego". T. 14A: Prawo własności przemysłowej. Red. S. Skubisz. Warszawa 2017, s. 121-131.

${ }^{13}$ Wyrok Trybunału Sprawiedliwości Wspólnot Europejskich w sprawie Centrafarm BV et Adriaan de Peijper v Sterling Drug Inc. (C-15/74) z dnia 31 października 1974 r., pkt 9; podobnie wyrok Trybunału Sprawiedliwości Wspólnot Europejskich w sprawie Pharmon v Hoechst (C-19/84) z dnia 9 lipca 1985 r., pkt 26.

${ }^{14}$ M. Kruk: Nadużycie idei ochrony patentowej — trolle patentowe. „Kwartalnik Urzędu Patentowego RP” 2013, wydanie specjalne, nr 5/18, s. 85.

15 Ibidem.

${ }^{16}$ S. Fusco: Markets and Patent Enforcement..., s. 441 i powołana tam literatura.

${ }_{17}$ A. Mayergoyz: Lessons from Europe..., s. 242 wraz z powołana tam literatura; por. także S. Fusco: Markets and Patent Enforcement..., s. 441. 
satą dla wynalazcy za poświęcony przez niego czas, środki finansowe oraz poniesione ryzyko jest monopol patentowy, który pozwala wyłączyć inne podmioty $\mathrm{z}$ korzystania $\mathrm{z}$ wynalazku przez ograniczony $\operatorname{czas}^{18}$. Co najważniejsze jednak, przeciwko naruszycielowi prawa wyłącznego uprawniony z patentu może wszcząć postępowanie sądowe, przy czym naruszyciel w celu własnej obrony może zakwestionować ważność patentu ${ }^{19}$. Groźba zakwestionowania patentu odstrasza uprawnionych od pochopnego nieuzasadnionego pozywania o naruszenie praw $\mathrm{z}$ patentu, tym samym stwarzając swoisty system równowagi ryzyka zarówno po stronie naruszyciela, jak i uprawionego z patentu ${ }^{20}$. Jak zostanie to jednak przedstawione w dalszej części artykułu, równowagę tę zaburza działalność trolli patentowych.

\section{Zjawisko trollingu patentowego}

Przed omówieniem działania trolli patentowych niezbędne jest poczynienie pewnych uwag terminologicznych. W literaturze na określenie podmiotów, o których mowa, używa się kilku różnych pojęć: non-practicing entity (NPE), patent-assertion entity (PAE), patent troll czy patent shark $^{21}$. Najszerszą kategorią podmiotów są NPE - podmioty nieprodukujące, które nie wytwarzają ani nie wprowadzaja na rynek produktów ucieleśniających rozwiązanie chronione patentem, do której to grupy zaliczyć można np. uniwersytety ${ }^{22}$. Wśród NPE można wyróżnić mniejszą kategorię podmiotów wyspecjalizowanych, zajmujących się pozyskiwaniem patentów oraz komercjalizacją ich przez uzyskiwanie opłat licencyjnych i wszczynanie procesów sądowych ${ }^{23}$. To właśnie w stosunku do tych podmiotów używa się pejoratywnego określenia „troll patentowy”24.

18 Ibidem.

${ }_{19}$ J. Chan, M. Fawcett: Footsteps of the Patent Troll. „Intellectual Property Law Bulletin” 2005, no. 1, s. 4.

${ }^{20}$ Ibidem.

${ }^{21}$ M. Kruk: Trolle patentowe..., s. 18. W niniejszym artykule, za wskazanym autorem, przyjęte zostały następujące tłumaczenia poszczególnych terminów: podmiot nieprodukujacy, podmiot utrzymujacy w mocy patent, troll patentowy oraz rekin patentowy. To ostatnie określenie używane jest stosunkowo rzadko.

${ }^{22}$ B.J. Love, Ch. Helmers, F. Gaessler, M. Ernicke: Patent Assertion..., s. 107; S. Fusco: Markets and Patent Enforcement..., s. 443.

${ }^{23}$ S. Fusco: Markets and Patent Enforcement..., s. 443.

${ }^{24}$ Ibidem. 
Trolle patentowe są podmiotami budującymi portfolio patentów, którym następnie posługuja się w celu uzyskania korzyści od innych podmiotów na rynku, korzystających z wynalazków chronionych patentami będącymi w posiadaniu trolla ${ }^{25}$. Podmioty te nie zajmuja się badaniami i rozwojem nowych technologii, nie biora udziału w procesie tworzenia innowacji ${ }^{26}$. Należy podkreślić, że ze względu na to, że trolle patentowe nie zajmuja się ani działalnością badawczą, ani też produkcją i wprowadzaniem towarów do obrotu, same utrzymują „bezpieczny dystans" i nie narażają się na zarzuty naruszenia czyichśs praw wyłącznych do wynalazku ${ }^{27}$. Cechuje je specyficzny model biznesowy, oparty na stosowaniu agresywnych i kosztownych strategii wszczynania postępowań $\mathrm{w}$ celu uzyskania nadmiernie wysokich opłat licencyjnych ${ }^{28}$. Podmioty utrzymujace w mocy patent koncentruja się na dwojakiego rodzaju działaniach: pozyskiwaniu praw wyłącznych w celach spekulacyjnych oraz monetyzacji patentu przez dochodzenie roszczeń ${ }^{29}$. Działalność trolli patentowych, polegająca na pozyskiwaniu patentów, a następnie egzekwowaniu roszczeń z nich wynikających, bywa także nazywana „polowaniem na licencje" ${ }^{30}$.

Trolle patentowe buduja swoje portfolio, pozyskując patenty od małych przedsiębiorców, dużych korporacji, podmiotów na skraju bankructwa, start-upów, samodzielnych wynalazców, szpitali, uniwersytetów czy nawet jednostek rządowych ${ }^{31}$. Patenty pozyskiwane przez trolle sa najczęściej patentami, które już zostały skomercjalizowane i wprowadzone na rynek. Co więcej, trolle patentowe koncentruja się na patentach stosunkowo starych, których okres ochrony jest już w zaawansowanym stadium, ponieważ łatwiej jest wtedy o potencjalne naruszenia,

${ }^{25}$ M. Kruk: Trolle patentowe..., s. 17.

${ }^{26}$ R. Sikorski: Patent Law at the Centre of Today's IP Debate. „IIC International Review of Intellectual Property and Competition Law" 2014, vol. 45, no. 2, s. 126; A. Mayergoyz: Lessons from Europe..., s. 242.

${ }^{27}$ M. Kruk: Trolle patentowe..., s. 18.

28 Ibidem.

${ }^{29}$ S. Fusco: Markets and Patent Enforcement..., s. 443.

${ }^{30}$ N.J. de Bisthoven: Patent Trolls and Abusive Patent Litigation in Europe: What the Unitary Patent Package Can Learn From the American Experiece? „Stanford-Vienna TTLF Working Paper No. 19” 2013, s. 14, http://ttlf.stanford.edu [Data dostępu: 31 grudnia 2017 r.].

${ }^{31}$ S. Fusco: Markets and Patent Enforcement..., s. 443; A. Mayergoyz: Lessons from Europe..., s. 242. Pogłębiona analiza źródeł patentów, które pozyskują trolle, została przedstawiona w raporcie przygotowanym dla Komisji Europejskiej w 2016 r., zob. Patent Assertion Entities in Europe. Eds. N. Thumm, G. Gabison (Joint Research Centre). Luxemburg 2016, s. 19-24, https://ec.europa.eu/jrc/en/publication/eur-scien tific-and-technical-research-reports/patent-assertion-entities-europe-their-impactinnovation-and-knowledge-transfer-ict-markets [Data dostępu: 31 grudnia 2017 r.]. 
gdyż technologia zastosowana w wynalazku funkcjonuje już na rynku od dłuższego czasu ${ }^{32}$. Stosunkowo często patenty w portfolio trolli patentowych to patenty konieczne do spełniania normy określonej przez organizację normalizacyjną (ang. standard essential patents) ${ }^{33}$. Wysoki odsetek patentów będących w posiadaniu podmiotów utrzymujących w mocy patent to patenty słabej jakości, czyli takie, które zostały uzyskane w niskiej jakości procedurze udzielenia patentu, zatem stosunkowo niewiele $\mathrm{z}$ nich przetrwałoby postępowanie unieważniające ${ }^{34}$.

Typowa strategia działania trolli jest utrzymywanie pozyskanych praw wyłącznych przez dłuższy czas niejako „w ukryciu”, a następnie, po uzyskaniu wiedzy, że podmioty na rynku poczyniły już spore inwestycje $\mathrm{w}$ daną technologię, wystąpienie z roszczeniami z tytułu naruszenia praw wyłącznych do wynalazku ${ }^{35}$. W takich sytuacjach podmioty, które stały się celem ataku trolli patentowych, są szczególnie na nie podatne, ponieważ poczynione już wydatki na wykorzystanie danego rozwiąania, które narusza prawa wyłączne trolla, sa tak znaczne, że wycofanie się z wykorzystywania konkretnej technologii powodowałoby zbyt duże straty dla tego podmiotu ${ }^{36}$. Trolle patentowe najczęściej zaczynają atak na przedsiębiorcę wykorzystującego daną technologię, wysyłając wezwanie do zaprzestania naruszeń, oskarżając go o naruszenie jednego lub wielu patentów ze swojego portfolio. Kolejnym krokiem trolla jest wysłanie do wybranego przez siebie podmiotu wezwania do płatności opłat licencyjnych, pozostawiając adresatowi wybór jednej z trzech możliwości zaprzestanie używania technologii, ale poniesienie znacznych kosztów zmiany wykorzystywanych rozwiązań, zawarcie licencji i zapłata najczęściej wygórowanych stawek lub wdanie się w spór sądowy o naruszenie praw wyłącznych ${ }^{37}$. W większości przypadków podmiot zaatakowany przez trolla zdecyduje się na zawarcie licencji na niekorzystnych warunkach, ze względu na obawy przed postępowaniem sądowym, którego wynik jest niepewny ${ }^{38}$.

${ }^{32}$ Patent Assertion Entities in Europe. Eds. N. Thumm, G. Gabison (Joint Research Centre)..., s. $19-20$.

${ }^{33}$ Ibidem, s. 21.

34 Ibidem, s. 22.

${ }^{35}$ S. Fusco: Markets and Patent Enforcement..., s. 444.

${ }^{36}$ Ibidem.

${ }^{37}$ Ibidem.

${ }^{38}$ Ibidem. 


\section{Skutki i legalnośé działalności trolli patentowych}

Rezultaty działalności trolli patentowych mają niebagatelny wpływ na rynek technologii. Do skutków tych należy zaliczyć m.in. obniżenie inwestycji w obszarze R\&D. Czasem, ze względu na szczególnie agresywne ataki, innowacyjne firmy decyduja się całkowicie zaprzestać rozwoju $\mathrm{w}$ tym obszarze, co prowadzi do spadku produkcji oraz zatrudnienia ${ }^{39}$. Działalność trolli patentowych pozbawia także konsumentów dostępu do produktów innowacyjnych ${ }^{40}$. Do negatywnych skutków działalności trolli należy również zaliczyć zaburzenie procesu standaryzacji technologii ${ }^{41}$.

Jednakże, jakkolwiek z punktu widzenia moralności działalność trolli patentowych nie byłaby naganna, w kontekście prawnym pozyskiwanie praw wyłacznych w celu spekulacji nie jest działaniem nielegalnym ${ }^{42}$. Systemy prawa patentowego dopuszczają sytuację, w której uprawnionym $\mathrm{z}$ patentu nie jest osoba wynalazcy. Aby móc dochodzić ochrony posiadanych praw wyłącznych, nie jest też konieczne korzystanie z wynalazku w postaci wytwarzania przedmiotów zawierajacych dane rozwiazanie $^{43}$. Cecha prawa patentowego jako jednego z praw na dobrach niematerialnych jest to, że uprawnionemu z patentu przysługuja prawa wyłączne na wzór prawa własności. Zatem uprawniony, nawet jeżeli nabył prawa w sposób pochodny, jak w przypadku większości trolli patentowych, może dochodzić wszystkich uprawnień wynikajacych z patentu ${ }^{44}$. Działalność trolli patentowych można uznać za nieetyczną, ale nie za

${ }^{39}$ R. Sikorski: Patent Law..., s. 126.

${ }^{40}$ Ibidem.

${ }^{41}$ Ibidem.

${ }^{42}$ M.G. Plasseraud: Les Patent Trolls, mauvais génies du monde des brevets. „Institut de Recherche en Propriété Intellectuelle” 2008, s. 2; N.J. de Bisthoven: Patent Trolls..., s. 22 .

${ }^{43}$ N.J. de Bisthoven: Patent Trolls..., s. 22. W polskim prawie podstawa zbywalności patentu jest art. 67 ustawy Prawo własności przemysłowej z dnia 30 czerwca $2000 \mathrm{r}$. Tekst jedn. Dz.U. 2017, poz. 776, zgodnie z którym patent jest zbywalny i podlega dziedziczeniu. Natomiast jeśli chodzi o korzystanie z patentu, to jest ono podstawowym prawem wynalazcy lub uprawnionego z patentu. Pojęcie „korzystanie” obejmuje wszelkie rodzaje stosowania rozwiązania chronionego patentem, czerpania z niego korzyści oraz dysponowania nim, w tym korzystanie w sensie cywilnoprawnym, w postaci pobierania z tegoż prawa pożytków, np. przez pobieranie opłat licencyjnych czy przeniesienie prawa z patentu. Por. szerzej P. Kostański, w: Prawo własności przemysłowej. Komentarz. Red. P. Kostański. Wyd. 2. Warszawa 2014, s. 372-373.

${ }^{44}$ N.J. de Bisthoven: Patent Trolls..., s. 22; por. także K. Szczepanowska-Kozłowska: Patent. W: E. Nowińska, U. Promińska, K. Szczepnowska-Kozłowska: Własność przemysłowa i jej ochrona. Warszawa 2014, s. 68-70. 
niezgodna z $\mathrm{z}$ prawem ${ }^{45}$. Jest to raczej wyzyskanie pewnego rodzaju luk w systemie ochrony patentowej, które sprawiaja, że nadużycia takie sa możliwe $^{46}$. Działalność trolli patentowych jest jaskrawym przypadkiem zaprzeczenia idei ochrony patentowej, która stanowi założenie całego systemu patentowego ${ }^{47}$.

\section{5. Środki przeciwdziałania nadużyciu ochrony patentowej w dyrektywie 2004/48/WE}

Na gruncie obowiązującego prawa Unii Europejskiej poszukiwanie mechanizmów ochronnych przed nadużyciem idei ochrony patentowej przez tzw. trolle patentowe należy rozpoczaćc od analizy postanowień dyrektywy 2004/48/WE w sprawie egzekwowania praw własności intelektualnej ${ }^{48}$.

\subsection{Informacje ogólne}

Procedury egzekwowania praw własności intelektualnej od długiego czasu stanowiły centrum zainteresowania na poziomie wspólnotowym ${ }^{49}$. Przed uchwaleniem dyrektywy wśród państw członkowskich występowały znaczne różnice w regulacji dotyczącej egzekwowania praw własności intelektualnej ${ }^{50}$. Dyrektywa $\mathrm{w}$ sprawie egzekwowania stanowi pierwsza próbę ingerencji Unii w kwestie dotyczące procedury oraz środków zaradczych w dziedzinie własności intelektualnej, natomiast wcześniejsze regulacje unijne skupiały się głównie na aspekcie materialnoprawnym ${ }^{51}$. Celem dyrektywy jest harmonizacja systemów prawnych państw członkowskich

${ }^{45}$ N.J. de Bisthoven: Patent Trolls..., s. 23.

${ }^{46}$ Ibidem.

${ }^{47}$ Ibidem. Trolling patentowy mianem nadużycia instytucji prawa patentowego określa także R. Skubisz: Własność przemystowa w systemie prawa..., s. 131.

${ }^{48}$ R. Jacob: Patent Trolls in Europe - Does Patent Law Require New Barriers? In: IP and Other Things: A Collection of Essays and Speeches. Ed. R. Jacob. Oxford-Portland 2015.

${ }^{49}$ L. Bently, B. Sherman: Intellectual Property Law. Oxford-New York 2009, s. 1068.

${ }^{50}$ E. Traple, M. du Vall: Ochrona praw podmiotowych. W: Prawo patentowe. Red. E. Traple..., s. 609.

${ }^{51}$ A. Del Rio: The Directive on the Enforcement of Intellectual Property Rights. More Base, Less Bite. „Hibernian Law Journal” 2006, no. 6, s. 159. 
odnośnie do procedury i środków egzekwowania praw własności intelektualnej $\mathrm{w}$ postępowaniu cywilnym ${ }^{52}$. Dyrektywa reguluje więc rodzaje roszczeń przysługujących uprawnionym oraz najważniejsze zagadnienia procesowe $^{53}$. Należy wspomnieć, że dyrektywa ustanawia jedynie minimalny zakres ochrony, natomiast państwa członkowskie moga w swoim prawie krajowym przewidzieć wyższe standardy ochrony ${ }^{54}$. Badajac zakres przedmiotowy, trzeba sięgnąc do art. 2 dyrektywy, z którego wynika, że przewidziane dyrektywa procedury i środki naprawcze stosuje się do wszelkich naruszeń praw własności intelektualnej określonych w prawie wspólnotowym i/lub prawie wewnętrznym zainteresowanego państwa członkowskiego ${ }^{55}$. W'śród państw członkowskich pojawiły się wątpliwości co do rzeczywistego zakresu tej regulacji, dlatego też Komisja Europejska wydała oświadczenie wyjaśniające jej zakres regulacji ${ }^{56}$. W oświadczeniu tym wyszczególniła prawa patentowe wraz z prawami wynikajacymi z dodatkowych świadectw ochronnych ${ }^{57}$. Dyrektywa w sprawie egzekwowania jest określana mianem TRIPS-plus, jako uzupełniająca i zarazem rozszerzajaca zakres porozumienia TRIPS ${ }^{58}$.

\subsection{Zasada proporcjonalności w dyrektywie 2004/48/WF}

Analizę postanowień dyrektywy należy rozpocząć od zasady proporcjonalności, która została wyrażona $\mathrm{w}$ art. $3^{59}$. Zgodnie z brzmieniem

${ }^{52}$ H. Żakowska-Henzler: Rynek wewnętrzny Unii Europejskiej a prawo własności przemystowej. W: „System Prawa Unii Europejskiej”. T. 23. Warszawa 2013, s. 113.

${ }^{53}$ Ibidem.

${ }^{54}$ Artykuł 2 ust. 1 dyrektywy: „Bez uszczerbku dla środków przewidzianych lub środków, które mogą być przewidziane w prawie wspólnotowym lub krajowym w zakresie, w jakim te środki mogą dawać właścicielom praw większe korzyści, przewidziane niniejszą dyrektywą procedury i środki naprawcze stosuje się, zgodnie z art. 3, do wszelkich naruszeń praw własności intelektualnej określonych w prawie wspólnotowym i/lub prawie wewnętrznym zainteresowanego Państwa Członkowskiego”. por. także: C. Seville: EU Intellectual Property Law and Policy. Cheltenham-Northampton 2009, s. 409; E. Traple, M. du Vall: Ochrona praw..., s. 609.

${ }_{55}$ Artykuł 2 ust. 1 dyrektywy.

${ }^{56}$ Oświadczenie Komisji dotyczące art. 2 dyrektywy 2004/48/WE Parlamentu Europejskiego i Rady w sprawie egzekwowania praw własności intelektualnej. Dz.Urz. UE L 94, 13.04.2005, s. 37; E. Traple, M. du Vall: Ochrona praw..., s. 609.

57 Ibidem.

${ }^{58}$ H. Żakowska-Henzler: Rynek wewnętrzny..., s. 113.

59 Artykuł 3 dyrektywy: „1. Państwa Członkowskie zapewniają objęte niniejszą dyrektywą środki, procedury i środki naprawcze niezbędne do stosowania praw własności intelektualnej. Powyższe środki, procedury i środki naprawcze są sprawiedliwe i słuszne oraz nie są nadmiernie skomplikowane czy kosztowne, ani też nie pociągają za sobą nie- 
tego artykułu, środki, procedury i środki naprawcze niezbędne do egzekwowania praw własności intelektualnej są sprawiedliwe i słuszne, ponadto mają być skuteczne, proporcjonalne i odstraszające oraz stosowane w taki sposób, aby zapobiec tworzeniu barier w handlu prowadzonym zgodnie z prawem, oraz by zapewnić zabezpieczenia przed ich nadużywaniem. Artykuł ten zawiera wskazówki dla państw członkowskich dotyczące ukształtowania środków, które stanowią implementację dyrektywy do prawa krajowego $0^{60}$. Ustanowiona $\mathrm{w}$ art. 3 zasada proporcjonalności ma także stanowić podpowiedź interpretacyjną dla sądów, w jaki sposób powinny one stosować środki służące egzekwowaniu praw własności intelektualnej ${ }^{61}$. Charakter tej zasady oraz jej znaczenie dla szczegółowych postanowień dyrektywy zdaje się potwierdzać umiejscowienie art. 3 w sekcji zatytułowanej Przepisy ogólne oraz nadany temu przepisowi przez ustawodawcę unijnego tytuł Obowiazki ogólne. Taka interpretacja byłaby zgodna z wykładnią systemową wewnętrzną i argumentem ze struktury aktu prawnego ${ }^{62}$.

Należy zadać pytanie, w jaki sposób należy rozumieć proporcjonalność środków, procedur i środków naprawczych ustanowionych przez dyrektywę 2004/48/WE. Otóż odpowiedź na nie jest zawarta właśnie w ust. 2 art. 3. Zgodnie z nim, środki te będą proporcjonalne, jeżeli, po pierwsze, nie będa stwarzały barier dla handlu prowadzonego zgodnie z prawem oraz, po drugie, będą stosowane w sposób zapobiegajacy ich nadużywaniu ${ }^{63}$. Sa to więc przesłanki proporcjonalności stosowanych środków. To elastyczne podejście do ich stosowania, ustanowione we wspomnianym art. 3, jest dalekie od automatyzmu prawnego ${ }^{64}$. Państwa członkowskie mają obowiązek pozwolić swoim organom sądowniczym na niestosowanie środków przewidzianych przez dyrektywę, jeżeli te byłyby nieproporcjonalne ${ }^{65}$. Zatem sądom pozostawia się w tym zakresie swobodę decyzyjna, czy zastosować środek, czy też nie.

rozsądnych ograniczeń czasowych czy nieuzasadnionych opóźnień. 2. Powyższe środki, procedury i środki naprawcze są również skuteczne, proporcjonalne i odstraszające, i stosowane w taki sposób, aby zapobiec tworzeniu ograniczeń handlu prowadzonego zgodnie z prawem i zapewnić zabezpieczenia przed ich nadużywaniem".

${ }^{60}$ H. Żakowska-Henzler: Rynek wewnętrzny..., s. 114.

61 A. Ohly: Three Principles of European IP Enforcement Law: Effectiveness, Proportionality, Dissuasiveness. In: Technology and Competition, Contributions in Honour of Hanns Ullrich. Ed. J. Drexl. Brussel 2009, s. 257.

${ }^{62} \mathrm{Na}$ temat wykładni systemowej wewnętrznej i znaczenia struktury aktu prawnego w procesie interpretacji szerzej Z. Tobor: W poszukiwaniu intencji prawodawcy. Warszawa 2013, s. 235-236 wraz z powołaną tam literatura.

${ }^{63}$ A. Ohly: Three Principles..., s. 256.

${ }^{64}$ R. Jacob: Patent Trolls...

${ }^{65}$ Ibidem. 


\subsection{Postanowienia szczegółowe dotyczące roszczeń w przypadku naruszenia praw własności intelektualnej w dyrektywie 2004/48/WE}

Celem dyrektywy w sprawie egzekwowania praw własności intelektualnej było ujednolicenie katalogu roszczeń przysługujących podmiotom, których prawa zostały naruszone ${ }^{66}$. W działalności trolli patentowych szczególne znaczenie będa miały roszczenia zakazowe i środki alternatywne przewidziane $\mathrm{w}$ dyrektywie.

$\mathrm{W}$ art. 11 zostało uregulowane roszczenie zakazowe ${ }^{67}$. Obowiązkiem państw członkowskich jest zapewnienie organom sądowym, w przypadkach, w których zapadła już decyzja dotycząca meritum sprawy, możliwości wydawania podmiotom naruszającym zakazu kontynuowania naruszenia. Taki zakaz może dotyczyć również pośredników, z których korzysta osoba trzecia w celu naruszenia praw własności intelektualnej. Z kolei art. 12 dyrektywy „pozwala we właściwych przypadkach i na żądanie osoby podlegającej środkom przewidzianym w niniejszej sekcji, jeśli osoba ta działała nieumyślnie i bez zaniedbania, a realizacja tych środków mogłaby spowodować dla niej nieproporcjonalne szkody, zamiast zastosowania środków przewidzianych w niniejszej sekcji właściwe organy sądowe moga zarządzić zapłacenie poszkodowanej stronie rekompensaty pieniężnej, jeśli takowa wydaje się stronie poszkodowanej rozsądnie zadowalająca"68. Artykuł 12 ustanawia więc wąsko zakreślony wyjątek, kiedy to sąd na żądanie naruszyciela może odstąić od wydania zakazu, a zamiast tego zasądzić rekompensatę pieniężną.

Istnieje swoiste przekonanie o automatyzmie wydawania zakazów dalszych naruszeń w przypadku roszczenia o zaniechanie, typowe dla

${ }^{66}$ H. Żakowska-Henzler: Rynek wewnętrzny..., s. 121.

67 Artykuł 11 dyrektywy: „Państwa Członkowskie zapewniają, że tam, gdzie podjęta została decyzja sądu stwierdzająca naruszenie prawa własności intelektualnej, organy sądowe mogą wydawać naruszającym zakaz kontynuacji naruszenia. Jeśli tak przewiduje prawo krajowe, niewypełnienie zakazu poddaje naruszającego, gdzie jest to właściwe, powtarzalnej karze pieniężnej w celu zapewnienia zgodności z zakazem. Państwa Członkowskie zapewniają też właścicielom możliwość składania wniosku o zakaz wobec pośredników, z usług których korzysta strona trzecia do naruszania prawa własności intelektualnej, bez uszczerbku dla postanowień art. 8 ust. 3 dyrektywy 2001/29/WE”.

68 Artykuł 12 dyrektywy: „Państwa Członkowskie moga przewidzieć, że we właściwych przypadkach i na żądanie osoby podlegającej środkom przewidzianym w niniejszej sekcji, jeśli osoba ta działała nieumyślnie i bez zaniedbania, a realizacja tych środków mogłaby spowodować dla niej nieproporcjonalne szkody, zamiast zastosowania środków przewidzianych w niniejszej sekcji właściwe organy sądowe moga zarządzić zapłacenie poszkodowanej stronie rekompensaty pieniężnej, jeśli takowa wydaje się stronie poszkodowanej rozsądnie zadowalająca”. 
systemów prawnych tradycji civil law, co miałoby czynić zadość istocie prawa wyłacznego, jakim jest prawo $\mathrm{z}$ patentu ${ }^{69}$. Jak wskazuje jednak A. Ohly, takie tradycyjne podejście nie przystaje do rozwijającego się przemysłu technologicznego i pojawiajacych się coraz to nowszych zjawisk zwiąanych z prawem patentowym, jak trolling patentowy czy też proces standaryzacji technologii ${ }^{70}$. Wzrastajace skomplikowanie systemu patentowego sprawia, że istnieje coraz większe prawdopodobieństwo naruszenia praw własności przemysłowej nawet przez przedsiębiorców chcacych je uszanować ${ }^{71}$. Ohly twierdzi, że przede wszystkim specyfika modelu biznesowego trolli patentowych sprawia, że automatyzm wydawania zakazów dalszego naruszania powodowałby stłumienie innowacji lub, odnosząc to do brzmienia art. 3 ust. 2 dyrektywy, mógłby tworzyć bariery handlu prowadzonego zgodnie $\mathrm{z}$ prawem ${ }^{72}$.

Jednak z treści art. 11 dyrektywy 2004/48/WE wyraźnie wynika, że obowiązkiem państwa członkowskiego jest tak ukształtować środek w postaci zakazu dalszych naruszeń, aby sądy mogły je wydawać, lecz nie automatycznie. Takie rozumienie pozostaje $\mathrm{w}$ zgodzie $\mathrm{z}$ zasada proporcjonalności ustanowiona $\mathrm{w}$ art. 3 dyrektywy oraz motywem 17 preambuły dyrektywy, który traktuje o tym, że procedury powinny być ustalane w sposób, który uwzględniać będzie specyfikę sprawy, rodzaj i szczególne cechy prawa oraz umyślny lub nieumyślny charakter naruszenia ${ }^{73}$.

Z kolei art. 12, zawierajacy środki alternatywne dla zakazu dalszych naruszeń, także pozostawia organom sądowym państw członkowskich władzę dyskrecjonalną w zakresie zarządzenia zapłaty rekompensaty pieniężnej, zamiast wydania zakazu dalszych naruszeń, ograniczoną jednak warunkami nieumyślności czynu i nieproporcjonalnej szkody dla naruszyciela. Wskazuje się, że art. 12 jest właśnie wyrazem zasady proporcjonalności oraz znajduje potwierdzenie w motywie 25 preambuły dyrektywy ${ }^{74}$.

\footnotetext{
${ }^{69}$ A. Ohly: Three Principles..., s. 259 i literatura powołana tam w przyp. 9.

${ }^{70}$ Ibidem, s. 260.

${ }^{71}$ Ibidem.

${ }^{72}$ Ibidem.

${ }^{73}$ Motyw 17. preambuły: „Przewidziane w niniejszej dyrektywie środki, procedury i środki naprawcze w każdym przypadku powinny być ustalane tak, aby w należyty sposób uwzględniały specyfikę sprawy, włączając szczególne cechy każdego prawa własności intelektualnej, i w stosownym przypadku umyślny lub nieumyślny charakter narusze-

${ }^{74}$ Motyw 25. preambuły: „Gdy naruszenie zostało popełnione nieumyślnie i bez zaniedbania, a przewidywane niniejszą dyrektywą środki naprawcze lub nakazy sądowe byłyby nieproporcjonalne, Państwa Członkowskie powinny mieć w odpowiednich przypadkach możliwość zastosowania środka alternatywnego w postaci rekompensaty pieniężnej na rzecz poszkodowanej strony. Jednakże tam, gdzie handlowe wykorzystywa-
} nia". 
W przypadku spraw, w których występuje troll patentowy, dochodzący roszczeń z tytułu naruszenia patentu koniecznego do spełnienia wymogów standaryzacyjnych, sąd może więc powstrzymać się od automatycznego wydania zakazu dalszych naruszeń, co wiąałoby się z ogromnymi szkodami dla naruszyciela, a zamiast tego, biorac pod uwage specyficzny model biznesowy trolli, jakim jest maksymalizacja zysków finansowych z tytułu posiadanych praw, w miejsce zakazu może zastosować rekompensatę pieniężna, co stanowiłoby mniejszą dolegliwość dla producenta. Do innych okoliczności, które sąd mógłby wziąć pod uwagę, można by także zaliczyć stosunek komponentu naruszającego patent do całości produkowanego urządzenia, kwestię, czy naruszajacy patent trolla opracował technologię samodzielnie, czy też zwyczajnie ja skopiował, oraz stosunek naruszajacej technologii do zastrzeżeń patentowych naruszanego patentu przysługujacego trollowi ${ }^{75}$.

\section{Unijne prawo konkurencji i sprawa Huawei v. ZTE}

Kwestia wydawania przez sądy zakazów dalszych naruszeń w przypadku naruszenia patentów koniecznych do spełnienia wymogu standaryzacyjnego była także przedmiotem decyzji Trybunału Sprawiedliwości UE w sprawie Huawei v. ZTE.

Przytaczając stan faktyczny w tej sprawie, Huawei jest właścicielem patentu europejskiego, który został zgłoszony do Europejskiego Instytutu Norm Telekomunikacyjnych (ETSI) jako SEP, czyli patent konieczny do spełnienia norm organizacji standaryzacyjnej, jaka jest ETSI, równocześnie, zobowiązując się do udzielania podmiotom trzecim licencji na wspomniany patent na warunkach uczciwych, rozsąnych i niedyskryminacyjnych (FRAND) ${ }^{76}$. ZTE, sprzedając na terenie Niemiec produkty

nie towarów podrabianych lub świadczenie usług byłoby naruszeniem prawa innego niż prawo własności intelektualnej lub mogłoby spowodować szkody dla konsumentów, takie wykorzystywanie lub świadczenie powinno zostać zakazane". Por. także: H. Ża kow ska-Henzler: Rynek wewnętrzny..., s. 123; A. Ohly: Three Principles..., s. 264.

75 A. Ohly: Three Principles..., s. 265 i powołana tam literatura. Warto wspomnieć, że postanowienia dyrektywy zostały transponowane do polskiego porządku prawnego przez nowelizację w 2007 r. ustawy Prawo własności przemysłowej, a dokładnie jej art. 287. Szerzej na ten temat E. Traple, M. du Vall: Ochrona praw..., s. 619—620.

${ }^{76}$ Wyrok Trybunału Sprawiedliwości Unii Europejskiej w sprawie Huawei Technologies Co. Ltd przeciwko ZTE Corp., ZTE Deutschland GmbH (C-170/13) z dnia 16 lipca 2015 r., pkt. 21—23. Przepisy proceduralne ETSI stanowią, że gdy ETSI otrzymuje infor- 
z oprogramowaniem związanym ze zgłoszoną normą i patentem, naruszyło prawa wyłączne Huaweia, dlatego też od 2010 r. prowadziło rozmowy w celu zawarcia umowy licencyjnej. Jednakże ze względu na różnice ofert do sfinalizowania negocjacji nie doszło ${ }^{77}$. W $2011 \mathrm{r}$. Huawei pozwał ZTE przed niemieckim sądem o naruszenie praw wyłącznych i wniósł m.in. o wydanie zakazu dalszych naruszeń. Sąd niemiecki natomiast zaczął rozważać, czy powództwo Huaweia nie stanowiło nadużycia pozycji dominujacej, w konsekwencji czego zawiesił postępowanie i zwrócił się z pytaniem prejudycjalnym do TSUE $^{78}$.

Bezwzględny zakaz nadużywania pozycji dominującej został wyrażony w art. 102 Traktatu o funkcjonowaniu Unii Europejskiej ${ }^{79}$. Artykuł ten zakazuje przedsiębiorcy lub przedsiębiorcom nadużywania pozycji dominującej na rynku wewnętrznym, lub znacznej jego części, w zakresie, w jakim mogłoby to wpłynać na handel pomiędzy państwami członkowskimi ${ }^{80}$. Jako przykład zostały wyliczone działania mogace stanowić nadużycie pozycji dominującej, jednakże nigdzie nie zdefiniowano ani pojęcia pozycji dominujacej, ani też nie uregulowano przesłanek, pozostawiając określenie ich znaczenia orzecznictwu TSUE oraz wydanym przez Komisję Europejska aktom o charakterze soft law ${ }^{81}$. Zakazane nie jest samo posiadanie pozycji dominujaccej ani jej zgodne z prawem wykorzystywanie, co oznacza m.in. posiadanie praw wyłącznych, ale wykorzystywanie tej pozycji w sposób niezgodny z prawem ${ }^{82}$. Jednakże odnoś-

mację o istnieniu istotnego dla danej normy prawa własności intelektualnej, dyrektor generalny ETSI wzywa niezwłocznie właściciela tego prawa do podjęcia, w terminie trzech miesięcy, nieodwołalnego zobowiązania do gotowości udzielania licencji na to rozwiazanie na warunkach FRAND.

${ }^{77}$ Ibidem, pkt. 24-26.

${ }^{78}$ Ibidem, pkt. 27-28.

${ }^{79}$ Wersja skonsolidowana Traktatu o funkcjonowaniu Unii Europejskiej. Dz.Urz. UE C 326, 26.10.2012, s. 47-390. Artykuł 102 TFUE stanowi: „Niezgodne z rynkiem wewnętrznym i zakazane jest nadużywanie przez jedno lub większą liczbę przedsiębiorstw pozycji dominującej na rynku wewnętrznym lub na znacznej jego części w zakresie, w jakim może wpływać na handel między Państwami Członkowskimi. Nadużywanie takie może polegać w szczególności na: a) narzucaniu w sposób bezpośredni lub pośredni niesłusznych cen zakupu lub sprzedaży albo innych niesłusznych warunków transakcji; b) ograniczaniu produkcji, rynków lub rozwoju technicznego ze szkodą dla konsumentów; c) stosowaniu wobec partnerów handlowych nierównych warunków do świadczeń równoważnych i stwarzaniu im przez to niekorzystnych warunków konkurencji; d) uzależnianiu zawarcia kontraktów od przyjęcia przez partnerów zobowiązań dodatkowych, które ze względu na swój charakter lub zwyczaje handlowe nie mają związku z przedmiotem tych kontraktów".

${ }^{80}$ A. Jurkowska-Gomułka, T. Skoczny: Wspólne reguty konkurencji Unii Europejskiej. W: „System Prawa Unii Europejskiej”. T. 24. Warszawa 2010, s. 70.

${ }^{81}$ Ibidem, s. $70-71$.

${ }^{82}$ Ibidem, s. 78; por. także H. Żakowska-Henzler: Rynek wewnętrzny..., s. 99. 
nie do praw własności intelektualnej Trybunał prezentował pogląd, że w szczególnych okolicznościach wykonywanie praw, np. odmowa udzielenia licencji przez podmiot zajmujaccy pozycję dominująca na rynku, może zostać uznane za jej nadużycie, mimo niewątpliwej wyłaczności tej decyzji po stronie uprawnionego z tytułu praw własności intelektualnej ${ }^{83}$.

Podobnie w przedmiotowej sprawie Trybunał stwierdził, że wnioskowanie o wydanie zakazu dalszych naruszeń przez uprawnionego z patentu, wymaganego do spełnienia normy standaryzacyjnej, może zostać uznane za nadużycie pozycji dominującej w pewnych specyficznych warunkach $^{84}$. Trybunał wskazał, że uprawniony z patentu musi przed wniesieniem powództwa należycie zawiadomić podmiot naruszajacy o skali naruszenia, na co naruszający powinien wyrazić swoją chęć zawarcia umowy licencyjnej ${ }^{85}$. Po wyrażeniu takiej woli uprawniony powinien przedstawić naruszającemu pisemną ofertę licencji na warunkach FRAND, na co naruszyciel starannie i w dobrej wierze winien udzielić bez zbędnej zwłoki odpowiedzi. Nie przyjmując przedstawionej oferty, winien złożyć własną kontrofertę $\mathrm{w}$ formie pisemnej i na proponowanych przez niego warunkach FRAND ${ }^{86}$. Jeżeli taka kontroferta zostanie odrzucona, naruszajacy powinien ustanowić zabezpieczenie, np. w formie gwarancji bankowej, na kwotę wynikająca z już dokonanych naruszeń, z których powinien móc złożyć rachunki. Jednocześnie zaś obydwie strony maja możliwość zwrócenia się do niezależnej trzeciej strony o ustalenie warunków FRAND ${ }^{87}$. Ponadto Trybunał wskazał, że naruszający powinien mieć możliwość podważenia zarówno ważności samego patentu, jak i naruszenia w trakcie negocjacji i po nich ${ }^{88}$. Ustanawiajac taki schemat działania, Trybunał dał wskazówkę sądom, w jaki sposób postępować w przypadku działalności trolli patentowych, których schemat zachowań jest podobny do wynikającego ze stanu faktycznego w omawianej sprawie.

${ }^{83}$ H. Żakowska-Henzler: Rynek wewnętrzny..., s. 101. Zarówno orzecznictwo, jak i doktryna powoływały się tutaj na rozmaite koncepcje, odróżniając istnienie praw własności intelektualnej od ich wykonywania oraz odwołując się do koncepcji „szczególnego przedmiotu prawa". Także w omawianej sprawie Trybunał podkreślił możliwość udzielenia licencji lub jej odmowę jako prerogatywę uprawnionego; Huawei v. ZTE, pkt 46.

${ }^{84}$ I. Nikolic: Who needs injunctions? Alternative remedies in standard essential patents disputes. „Journal of Intellectual Property Law \& Practice” 2017, vol. 12, no. 2, s. 131.
${ }^{85}$ Ibidem, pkt. $61,63$.
${ }^{86}$ Ibidem, pkt. $63-65$.
${ }^{87}$ Ibidem, pkt. $67-68$.
${ }^{88}$ Ibidem, pkt 69. 


\section{Kwestia Jednolitego Sądu Patentowego i jego wpływ na trolling patentowy}

W kontekście przeciwdziałania trollingowi patentowemu $\mathrm{w}$ prawie unijnym nie sposób pominąc kwestii patentu europejskiego o jednolitym skutku oraz postępowania przed Jednolitym Sadem Patentowym. Jednakże z uwagi na objętość niniejszego opracowania oraz niepewność przyszłości systemu poczynione zostaną tym względzie jedynie pewne wzmianki.

Porozumienie o Jednolitym Sądzie Patentowym stanowi część tzw. Unitary Patent Package, na który oprócz porozumienia składają się dwa rozporządzenia unijne - rozporządzenie Parlamentu Europejskiego i Rady UE 1257/2012 z dnia 17 grudnia 2012 r. wprowadzajace wzmocnioną współpracę $\mathrm{w}$ dziedzinie tworzenia jednolitego systemu ochrony patentowej oraz rozporządzenie Rady UE z dnia 17 grudnia 2012 r. wprowadzajace wzmocniona współprace w dziedzinie tworzenia jednolitego systemu ochrony patentowej w odniesieniu do majacych zastosowanie ustaleń dotyczących tłumaczeń ${ }^{89}$. Należy podkreślić, że porozumienie formalnie nie należy do pierwotnego czy wtórnego prawa unijnego, a jest umową zawartą pomiędzy państwami członkowskimi. Umowy takie moga wywierać istotny wpływ na stosowanie prawa unijnego ${ }^{90}$, co znajduje potwierdzenie w przypadku porozumienia o Jednolitym Sądzie Patentowym. Mianowicie rozpoczęcie stosowania rozporządzenia o patencie europejskim o jednolitym skutku jest uzależnione od wejścia w życie porozumienia o Jednolitym Sądzie Patentowym ${ }^{91}$. Jednakże z uwagi na planowaną procedurę wyjśsia Wielkiej Brytanii z Unii Europejskiej

${ }^{89}$ Rozporządzenie o patencie jednolitym. Dz.Urz. UE L 361, 31.12.2012, s. 1-8; rozporządzenie o tłumaczeniach. Dz.Urz. UE L 361, 31.12.2012, s. 89-92; por. także P. du Vall: Jednolity system ochrony patentowej w Unii Europejskiej. Uwagi szczegółowe. W: Prawo patentowe. Red. E. Traple..., s. 128.

90 J. Maliszewska-Nienartowicz: System instytucjonalny $i$ prawny Unii Europejskiej. Toruń 2010, s. 295.

${ }_{91}$ P. du Vall: Jednolity system..., s. 128. Artykuł 18 ust. 2 rozporządzenia 1257/2012: „2. Niniejsze rozporządzenie stosuje się od dnia 1 stycznia 2014 r. lub od dnia wejścia w życie Porozumienia w sprawie Jednolitego Sądu Patentowego (zwanego dalej "porozumieniem«), w zależności od tego, która data jest późniejsza. W drodze odstępstwa od art. 3 ust. 1 i 2 oraz art. 4 ust. 1 patent europejski, którego jednolity skutek został wpisany do rejestru jednolitej ochrony patentowej, ma jednolity skutek jedynie w tych uczestniczących państwach członkowskich, w których Jednolity Sąd Patentowy ma wyłączną jurysdykcję w odniesieniu do patentów europejskich o jednolitym skutku w dniu wpisania do rejestru". 
przyszłość patentu europejskiego o jednolitym skutku pozostaje pod znakiem zapytania ${ }^{92}$.

W dyskusji na temat skutków wprowadzenia jednolitego patentu europejskiego pojawiło się wiele argumentów za stanowiskiem, że takie rozwiązanie ułatwi działanie trolli patentowych i zachęci tego typu podmioty do większej aktywności w Unii Europejskiej. Wśród przyczyn zwiększonej aktywności trolli wymienia się: zakazy sądowe obejmujące ogromny rynek, możliwość powielenia niemieckiego rozwiązania rozdzielonego postępowania, w którym zakazy sa wydawane przed badaniem ważności patentu, zwiększone zjawisko forum shopping ${ }^{93}$. Analizując jednak przytoczone poniżej postanowienia porozumienia o Jednolitym Sądzie Patentowym, można przyjąć, że jego twórcy przewidzieli możliwe negatywne skutki i postarali się je zminimalizować.

Jednolity Sad Patentowy zostaje ustanowiony w celu rozstrzygania sporów dotyczących patentów europejskich o jednolitym skutku oraz klasycznych patentów europejskich. Sąd składa się z sądu I instancji (oddział centralny oraz oddziały lokalne i regionalne dla dwóch lub więcej umawiajacych się państw) oraz sądu apelacyjnego. Składy orzekajace tworzyć będą sędziowie posiadajacy kwalifikacje prawne i sędziowie posiadajacy kwalifikacje techniczne ${ }^{94}$. Prawo, na podstawie którego Jednolity Sąd Patentowy ma orzekać, to prawo unijne z przyznanym mu pierwszeństwem, porozumienie o jednolitym sądzie patentowym, konwencja o patencie europejskim, inne porozumienia majace zastosowanie do patentów i wiążące dla wszystkich umawiających się państw oraz prawa krajowe ${ }^{95}$.

${ }^{92}$ P. du Vall: Jednolity system..., s. 128-129. Więcej na temat skutków tzw. Brexitu dla systemu patentu europejskiego o jednolitym skutku L.C. Ubertazzi: Brexit and the EU patent. „Journal of Intellectual Property Law \& Practice” 2017, vol. 12, no. 6, s. $516-525$.

${ }^{93}$ Patent Assertion Entities in Europe. Eds. N. Thumm, G. Gabison (Joint Research Centre)..., s. 42-43.

${ }_{94}$ Artykuł 1 zd. 1 porozumienia: „Niniejszym ustanawia się Jednolity Sąd Patentowy w celu rozstrzygania sporów dotyczacych patentów europejskich i patentów europejskich o jednolitym skutku”. Artykuł 6: 1. „Sąd składa się z Sądu Pierwszej Instancji, Sądu Apelacyjnego i Sekretariatu. 2. Sąd wykonuje zadania przydzielone mu na mocy niniejszego porozumienia”. Artykuł 7 ust. 1: „Sąd Pierwszej Instancji składa się z oddziału centralnego oraz z oddziałów lokalnych i regionalnych”. Artykuł 15 ust. 1: „W skład Sądu wchodzą sędziowie posiadajacy kwalifikacje prawne i sędziowie posiadający kwalifikacje techniczne. Sędziowie zapewniają najwyższy stopień kompetencji i maja udowodnione doświadczenie w dziedzinie rozstrzygania sporów patentowych”. Por. także P. du Vall: Jednolity system..., s. 136-138.

${ }_{95}$ Artykuł 24 ust. 1: „W pełni przestrzegajac art. 20, przy rozpatrywaniu sprawy wniesionej na mocy niniejszego porozumienia, Sąd orzeka na podstawie: a) prawa Unii, w tym rozporządzenia (UE) nr 1257/2012 oraz rozporządzenia (UE) nr 1260/2012 (1); 
Jeśli chodzi o minimalizację skutków działań trolli patentowych, to istotnym postanowieniem proceduralnym porozumienia jest art. 42, ustanawiający zasadę proporcjonalności oraz stosowania środków zaradczych i procedur w sposób uczciwy, sprawiedliwy i niezakłócający konkurencji ${ }^{96}$. Jest to zasada bardzo podobna do tej z art. 3 dyrektywy 2004/48/ WE. Zasada ta powinna pozwolić sędziom orzekać w sposób, który przeciwdziałać będzie nadużyciom trolli patentowych ${ }^{97}$. W art. 63 porozumienia została ustanowiona wyraźnie dyskrecjonalna władza sądu w wydawaniu nakazów stałych zaprzestania naruszeń, co będzie miało podobne skutki, jak postanowienie art. 11 dyrektywy 2004/48/WE ${ }^{98}$. Natomiast jeżeli chodzi o typową dla trolli patentowych strategię pozywania wielu podmiotów jednocześnie, to art. 33 porozumienia ustanawia zasadę, że powództwo przeciwko wielu pozwanym może zostać wniesione wyłacznie wtedy, gdy pozwani sa z sobą związani komercyjnie, a powództwo dotyczy tego samego domniemanego naruszenia ${ }^{99}$.

b) niniejszego porozumienia; c) EPC; d) innych porozumień międzynarodowych majacych zastosowanie do patentów i wiążących dla wszystkich umawiających się państw członkowskich; oraz e) prawa krajowego”. Artykuł 20: „Sąd stosuje prawo Unii w całości i uznaje jego pierwszeństwo".

${ }^{96}$ Artykuł 42: „1. Sąd rozstrzyga spory w sposób proporcjonalny do ich znaczenia i złożoności. 2. Sąd zapewnia, aby zasady, procedury i środki zaradcze przewidziane w niniejszym porozumieniu i w statucie były stosowane w sposób uczciwy i sprawiedliwy, oraz by nie zakłócały konkurencji”.

97 E. Kelly, C. Carroll: How The EU Patent Court Will Protect Against Trolls. „Law360”11.03.2013, https://www.law360.com/articles/418482/how-the-eu-patent-courtwill-protect-against-trolls [Data dostępu: 31 grudnia 2017 r.].

98 Artykuł 63 ust. 1 porozumienia: „Jeżeli wydane zostanie orzeczenie stwierdzające naruszenie patentu, Sąd może wydać nakaz wobec sprawcy naruszenia zakazujacy dalszego naruszania. Sąd może również wydać taki nakaz wobec pośrednika, z którego usług korzysta strona trzecia w celu naruszania patentu”. Por. także E. Kelly, C. Car roll: How The EU...

${ }_{99}$ Artykuł 33 ust. 1 lit. b): „Bez uszczerbku dla ust. 7 niniejszego artykułu powództwa, o których mowa w art. 32 ust. 1 lit. a), c), f) i g), wnosi się do: b) oddziału lokalnego znajdującego się na terytorium umawiającego się państwa członkowskiego, na którym pozwany lub - w przypadku wielu pozwanych — jeden z pozwanych ma miejsce zamieszkania lub główne miejsce prowadzenia działalności, lub przy braku miejsca zamieszkania lub głównego miejsca prowadzenia działalności, na terytorium którego pozwany lub jeden z pozwanych ma miejsce prowadzenia działalności, lub do oddziału regionalnego, pod który podlega dane umawiające się państwo członkowskie. Powództwo może zostać wniesione przeciw wielu pozwanym wyłącznie wtedy, gdy pozwani są ze soba powiązani komercyjnie, a powództwo dotyczy tego samego domniemanego naruszenia". Por. również E. Kelly, C. Carroll: How The EU... 


\section{Podsumowanie}

Zjawisko trollingu patentowego, mimo szkodliwości dla sektora technologicznego i innowacji, jest niestety, z punktu widzenia prawa, działaniem całkowicie legalnym. Jest jednak nieetyczne, jeśli chodzi o ocenę moralna. Pomimo terytorialnego charakteru prawa patentowego, pewne regulacje mające na celu harmonizacje prawa na poziomie unijnym moga zostać uznane jako środki zapobiegania lub przynajmniej minimalizacji szkodliwych skutków działań trolli patentowych. Regulacje te, w szczególności przepisy dyrektywy 2004/48/WE, zakładaja, że środki zaradcze będą przez sądy państw członkowskich stosowane proporcjonalnie i każdorazowo z uwzględnieniem specyfiki sprawy. Wydaje się, że powierzenie stosowania takich środków w zakresie dyskrecjonalnej władzy sędziego stanowi najlepszy możliwy „wentyl bezpieczeństwa”. Podobne postanowienia odnajdziemy w porozumieniu o Jednolitym Sązie Patentowym, zatem twórcy systemu przewidzieli, że przed zjawiskiem nadużycia ochrony patentowej należy się bronić i minimalizować jego skutki. Jednak bardziej bezpośrednia walka z trollami patentowymi wymagałaby zmian na poziomie prawa patentowego poszczególnych krajów. Jednoznaczne określenie znamion trollingu mogłoby być jednak utrudnione, ze względu na to, że w grupie podmiotów nieprodukujacych znajdują się także inne podmioty niż nastawione wyłącznie na zysk trolle patentowe. Czy obecne regulacje okażą się wystarczające, trudno jest na razie jednoznacznie określić, ponieważ trolling patentowy w Europie nie osiągną jeszcze takich rozmiarów jak w Stanach Zjednoczonych. Pozostaje jednak mieć nadzieję, że nie osiagnie, a obecne regulacje okażą się wystarczającymi przynajmniej w stopniu minimalnym. 


\title{
Łukasz Maryniak*
}

\section{Konstrukcje prawne chroniące przed copyright trollingiem}

\begin{abstract}
In this article it's author describes legal solutions protecting internet users against copyright trolling. Firstly, it is shown that the force of copyright is not absolute. International regulations (such as Paris Act relating to the Berne Convention and TRIPS agreement) state that there is a possibility for member states to provide some exceptions to exclusive rights, which allow to use a copyrighted work under some specific conditions without asking for permission it's author and without infringing copyright. Secondly, three most common "exceptions systems" are described - fair dealing, fair use-European type (on the Polish example) and American fair use. In summary the author of this article underlines that to find out if a use of copyright work in the Internet is indeed a copyright infringement, a detailed analysis of law provisions is necessary meanwhile copyright trolls do not make such reflection before they make their claims.
\end{abstract}

Keywords: copyright trolling, fair dealing, fair use

Zjawisko copyright trollingu polega na podejmowaniu działań oficjalnie zmierzających do ochrony praw autorskich w Internecie ${ }^{1}$, które w rzeczywistości prowadzą do wykorzystania istniejacych instytucji prawnych (roszczeń) w sytuacjach, w których uprawnionemu (twórcy lub jego następcy prawnemu) ochrona prawna nie przysługuje ${ }^{2}$ lub też przysługu-

* Dr, Uniwersytet Śląski w Katowicach.

${ }^{1}$ O. Wrzeszcz: Trolling prawnoautorski (,copyright trolling”). W: „Prace z Prawa Własności Intelektualnej” 2016, s. 38.

${ }^{2}$ N. Mileszyk: „Copyright trolling”-skala zjawiska i propozycje rozwiazań, https:// centrumcyfrowe.pl/blog/2016/03/10/copyright-trolling-skala-zjawiska-i-propozycje-roz wiazan/ [Data dostępu: 3 listopada 2017 r.]. 
je, ale w węższym zakresie niż wynika z jego żądań. Internetowi trolle często korzystaja z niewiedzy potencjalnych naruszycieli, jednocześnie silnie oddziałując na ich emocje przez zastraszenie. Używając sformalizowanego języka prawniczego i powołując się na konkretne roszczenia opisane w przepisach prawa, grożą wstąpieniem na drogę postępowania sądowego, jeżeli adresat pisma (wezwania) nie spełni żądań trolla w postaci - najczęściej — zapłaty określonej sumy pieniężnej. Zdarza się, że wezwania otrzymuja osoby niemające nawet kontaktu z utworem, którego miałoby dotyczyć naruszenie ${ }^{3}$. Zwykle jednak żądania kierowane są do internautów (ustalonych na podstawie adresów IP), którzy w jakiś sposób korzystali z danego dzieła ${ }^{4}$ — oglądali je, ściągali lub kopiowali.

Istota problemu jest fakt, że roszczenia wystosowane do takich osób sa zazwyczaj bezpodstawne lub przynajmniej dyskusyjne. Działania internautów nie ingeruja bowiem bezprawnie — jak wskazują trolle $\mathrm{w}$ monopol prawnoautorski, ale podejmowane sa na podstawie upoważnień przyznanych im w powszechnie obowiąujących przepisach prawa. Pominąwszy sytuacje rozsyłania wezwań do zupełnie przypadkowych podmiotów, cechą charakterystyczną copyright trollingu jest zatem nieuznawanie określonych w prawie wyjątków od zasady wyłączności praw autorskich (np. w postaci instytucji dozwolonego użytku) czy też precyzyjniej: utwierdzanie internauty $\mathrm{w}$ przeświadczeniu, jakoby wspomniane wyjatki nie istniały.

Tymczasem współcześnie systemy prawne różnych państw dopuszczają w ściśle określonych przypadkach korzystanie z utworu bez zgody twórcy (a nawet wbrew jego woli5), na podstawie takich instytucji, jak dozwolony użytek, fair use czy fair dealing ${ }^{6}$.

${ }^{3}$ Na przykład przypadek staruszki, która była jedynie stroną umowy o dostarczanie usługi Internetu, zob. A. Goska: „Copyright trolling” - wezwania do zapłaty, http:// www.infor.pl/prawo/prawa-konsumenta/konsument-w-sieci/700843, Copyright-trollingwezwanie-do-zaplaty.html [Data dostępu: 3 listopada 2017 r.].

${ }^{4} \mathrm{~W}$ niniejszym artykule w celu uniknięcia powtórzeń pojęcie „dzieło” będzie używane zamiennie z pojęciem „utwór”, a zatem będzie oznaczało przedmiot prawa autorskiego.

${ }^{5} \mathrm{O}$ charakterze obowiąującego w polskim systemie prawnym dozwolonego użytku osobistego w kontekście możliwości jego ograniczenia lub wyłączenia mocą czynności prawnej zob. rozważania w dalszej części niniejszego artykułu.

${ }_{6}^{6}$ M. Barczewski: Traktatowa ochrona praw autorskich i praw pokrewnych. 2007. LEX, pkt 2.8. 


\section{Geneza wyjątków od zasady wyłączności autorskich praw majątkowych}

Gdy na świecie pojawiały się pierwsze regulacje prawne dotyczące ochrony własności intelektualnej (XVIII w.), nie poruszano w nich w ogóle kwestii korzystania z utworu bez zgody twórcy. Po pierwsze bowiem nie było takiej potrzeby, gdyż zwielokrotnianie egzemplarzy dzieł było zarówno bardzo trudne technicznie, jak i drogie ${ }^{7}$, po drugie natomiast w uchwalanych aktach prawnych skupiano się przede wszystkim na ochronie praw twórców.

Konieczność właściwego uregulowania możliwości korzystania z utworu bez zgody jego twórcy dostrzeżono dopiero wraz z upowszechnieniem się urządzeń służących do masowego kopiowania dzieł, czyli wraz z rozwojem ksero, w drugiej połowie XX w. W związu z tym Konwencja berneńska o ochronie dzieł literackich i artystycznych z dnia 9 września 1886 r. została uzupełniona w dniu 24 lipca 1971 r. o Akt paryski ${ }^{8}$, zmieniający (m.in.) dotychczasową treść art. 9 Konwencji ${ }^{9}$. W przepisie tym z jednej strony zapewniono twórcom wyłączne prawo do udzielania zezwolenia na reprodukcje ich dzieł (ust. 1), z drugiej natomiast dopuszczono w ustawodawstwach krajowych uchwalenie norm prawnych upoważniających użytkowników do kopiowania utworów „w pewnych szczególnych wypadkach, pod warunkiem że reprodukcja ta nie wyrządzi szkody normalnemu korzystaniu z dzieła ani nie przyniesie nieuzasadnionego uszczerbku prawowitym interesom autora" (ust. 2). Co bardzo istotne, sygnatariuszami Konwencji berneńskiej są aż 172 państwa ${ }^{10}$.

${ }^{7}$ E. Konopczyńska: Granice dozwolonego użytku prywatnego, s. 3-4, https://cen trumcyfrowe.pl/wp-content/uploads/2013/02/Granice-dozwolonego-u\%C5\%BCytku-pry watnego.pdf [Data dostępu: 4 listopada 2017 r.].

8 Zob. dokument o przystąieniu Rzeczypospolitej Polskiej do artykułów od 1 do 21 oraz do załącznika do Aktu paryskiego konwencji berneńskiej o ochronie dzieł literackich i artystycznych, sporządzonego w Paryżu dnia 24 lipca 1971 r., z dnia 24 lipca 1971 r. Dz.U. 1994, nr 104, poz. 506.

${ }_{9}$ Konwencja zawierała do tej pory pewne postanowienia dotyczące możliwości korzystania z utworu bez zgody twórcy, jednakże tylko w zakresie dozwolonego użytku publicznego, a zatem jedynie w wyjątkowych, ściśle określonych przypadkach (zob. np. art. 2 bis i art. 10). Dopiero art. 9 wprowadził bardziej abstrakcyjne sformułowanie rozszerzające dopuszczalny zakres korzystania z dzieł; zob. R. Sikorski: Ocena dozwolonego użytku w prawie autorskim w świetle kryteriów testu trójstopniowego. W: Granice prawa autorskiego. Red. M. Kępiński. Warszawa 2010, s. 26.

10 Stan na wrzesień 2016 r., https://en.wikipedia.org/wiki/Berne_Convention [Data dostępu: 4 listopada 2017 r.]. 
Podobne uregulowania znalazły się w innych aktach prawa międzynarodowego. W Porozumieniu $\mathrm{w}$ sprawie handlowych aspektów praw własności intelektualnej (TRIPS) z dnia 22 grudnia 1994 r. $^{11}$, w art. 13, wskazano, że „Członkowie zawężą ograniczenia lub wyjątki od praw wyłącznych do określonych przypadków specjalnych, które nie będą w sprzeczności z normalnym wykorzystaniem dzieła i nie spowodują bezzasadnej szkody prawomocnym interesom posiadacza prawa własności dzieła"12. Z kolei w obszernym art. 5 Dyrektywy 2001/29/WE Parlamentu Europejskiego i Rady z dnia 22 maja 2001 r. w sprawie harmonizacji niektórych aspektów praw autorskich i pokrewnych w społeczeństwie informacyjnym ${ }^{13}$ wskazano konkretne czynności, jakie moga stanowić wyjątki od praw wyłącznych, jeżeli tak zdecydują w swych ustawodawstwach Państwa Członkowskie, ponownie z zastrzeżeniem, że nie będa one naruszać normalnego korzystania z dzieła i nie będa powodować nieuzasadnionej szkody dla uzasadnionych interesów podmiotów prawa autorskiego (por. art. 5 ust. 5).

Wprawdzie $\mathrm{w}$ przywołanych aktach prawa międzynarodowego i wspólnotowego mowa jest o możliwości, a nie obowiązku wprowadzenia przez poszczególne państwa wyjątków od zasady wyłączności autorskich praw majątkowych, jednak ich istnienie w ustawodawstwach krajowych jest powszechne. Regulacje ustawowe upoważniające użytkowników do korzystania z utworów w oznaczonym zakresie bez konieczności uzyskania zgody twórcy są bowiem, jak się przyjmuje w doktrynie ${ }^{14}$, wyrazem realizmu prawodawcy, który nie chce tworzyć martwego prawa. Uchwalając przepisy dotyczace ochrony prawa autorskiego, zdawano sobie sprawę z tego, że odbiorca danego dzieła będzie chciał się jego treścią podzielić z innymi osobami. Gdyby takie instytucje, jak dozwolony użytek osobisty, nie istniały, to biorac pod uwagę literalne brzmienie przepisów, nabywca płyty DVD z zapisanym na niej filmem dokonywałby naruszenia prawa autorskiego (polegającego na bezprawnym rozpowszechnianiu utworu), gdyby wspomnianą płytę odtwarzał na laptopie wspólnie ze swoimi krewnymi.

11 Dz.Urz. UE L 336, s. 214.

${ }^{12}$ Norma ta, podobnie jak - nieco inaczej sformułowane - postanowienia art. 9 Aktu paryskiego, została określona w literaturze mianem „testu trójstopniowego”; więcej o teście trójstopniowym zob. R. Sikorski: Ocena dozwolonego użytku...; J. Barta, R. Markiewicz: Prawo w Światowej Organizacji Handlu. Kraków 1996; Eidem: Trzystopniowy test $z$ art. 35 pr. aut. i pr. pokr. „Zeszyty Naukowe Uniwersytetu Jagiellońskiego. Prace z Prawa Własności Intelektualnej” 2009, z. 4.

${ }^{13}$ Dz.Urz. UE L 167, s. 10, z późn. zm.

${ }_{14}$ Zob. J. Preussner-Zamorska: Dozwolony użytek chronionych utworów. W: „System Prawa Prywatnego”. T. 13: Prawo autorskie. Red. J. Barta. 2013. LEGALIS, s. $524-525$. 
Z tego też względu w ustawodawstwach krajowych przyjmowano różnego rodzaju rozwiązania regulujace sposób i zakres dopuszczalnej eksploatacji dzieła przez użytkownika. Na potrzeby niniejszego artykułu należy wyszczególnić trzy rodzaje instytucji występujące w różnych systemach prawnych, a mianowicie: fair dealing (który zostanie omówiony na przykładzie Australii), fair use (obowiązujący w Stanach Zjednoczonych Ameryki) oraz dozwolony użytek (osobisty i publiczny, który zostanie omówiony na przykładzie Polski).

\section{Fair dealing}

Rozwiąanie określane mianem fair dealing obowiąuje w niektórych państwach Wspólnoty Narodów (m.in. w Australii, Kanadzie i Wielkiej Brytanii) ${ }^{15}$. W odróżnieniu od fair use, a nawet dozwolonego użytku (zwłaszcza osobistego), w przypadku sprawiedliwego postępowania przepisy prawa nie wprowadzaja uniwersalnych sformułowań, które upoważniałyby użytkownika do korzystania (w pewnych sytuacjach) potencjalnie z każdego utworu. Zamiast tego ustawy szczegółowo wyliczaja, jakich konkretnie czynności można dokonać, w jakich okolicznościach oraz w stosunku do jakich utworów (muzycznych, słownych, audiowizualnych etc.). Podstawowa wadą omawianej instytucji jest więc niesłychana kazuistyka, co zostanie ukazane na przykładzie australijskich przepisów (Copyright Act 1968 [dalej: ACA]) ${ }^{16}$. Zwolennicy fair dealing podkreślaja jednak, że precyzyjne ustawowe sformułowania ${ }^{17}$ daja adresatom norm jasną odpowiedź na pytanie, co jest dozwolone, a co będzie stanowić naruszenie prawa autorskiego $0^{18}$.

I tak np. przepisy ACA przewiduja określony katalog czynności niestanowiących naruszenia prawa autorskiego:

15 https://en.wikipedia.org/wiki/Fair_dealing [Data dostępu: 13 listopada 2017 r.].

16 https://www.legislation.gov.au/Details/C2017C00180 [Data dostępu: 13 listopada 2017 r.].

${ }_{17} \mathrm{~W}$ pewnych sytuacjach tak znacząca liczba przepisów może wprowadzać równie dużą niepewność, jak ogólne sformułowania fair use; zob. G.W. Austin: Four questions about the Australian approach to fair dealing defenses to copyright infringement. „Journal of the Copyright Society of the U.S.A.", wiosna 2010. Westlaw, s. $616-618$.

18 A przynajmniej mniejszym „złem” jest wertowanie licznych przepisów w poszukiwaniu odpowiedzi, niż przeglądanie wyroków sądowych, jak ma to miejsce w przypadku fair use. 
1) niezależnie od rodzaju eksploatowanego utworu ${ }^{19}$ (część III dział 3 ACA);

2) tylko jeśli przedmiotem eksploatacji są utwory literackie, dramatyczne (teatralne) lub muzyczne (część III dział 4 ACA);

3) tylko jeśli przedmiotem eksploatacji jest program komputerowy (część III dział 4A ACA);

4) tylko jeśli przedmiotem eksploatacji są utwory artystyczne (część III dział 4B i dział 7);

5) tylko jeśli przedmiotem eksploatacji jest sztuka audiowizualna ${ }^{20}$ (niektóre przepisy części IV działu 6).

Należy pamiętać, że czynności, jakie można podjać w stosunku do utworów określonego rodzaju, są różne - inne są też sytuacje (cele), w których dane działanie jest uznane za sprawiedliwe. Na przykład chcąc sprawdzić, czy wykorzystanie kopii fragmentów publikacji w trakcie zajęć ze studentami nie stanowi naruszenia prawa autorskiego, należy w pierwszej kolejności odszukać przepisy dotyczące utworów literackich (część III dział $3 \mathrm{ACA}$ ), następnie zbadać normy regulujące korzystanie z tych dzieł w celach naukowych (art. 40 pkt 1 ACA), sprawdzić, czy działanie jest sprawiedliwym postępowaniem (art. 40 pkt 2 ACA) ${ }^{21}$, i wreszcie - czy dozwolone jest zwielokrotnianie danego utworu, tzn. czy kopiowanie przybiera „racjonalne rozmiary”, przez co należy rozumieć liczbę stron, rozdziałów lub słów ściśle określone w ustawowej tabelce (art. 40 pkt 5) ${ }^{22}$.

Abstrahujac od oceny systemu fair dealing ${ }^{23}$, wprowadzane nowelizacje (rozszerzające katalog czynności niestanowiących naruszenia prawa autorskiego w związku z pojawianiem się nowych technologii), świadczą o tym, że istnienie przepisów stanowiących wyjątki od zasady wyłączności praw autorskich jest absolutną koniecznością, czego zdają się nie dostrzegać internetowi trolle.

${ }^{19}$ Za utwór uznaje się dzieła literackie, dramatyczne (teatralne), muzyczne oraz utwory artystyczne (czyli m.in.: obrazy, rzeźby, fotografie, budynki, a także inne wytwory rzemiosła artystycznego); por. art. 10 ACA (definicje ustawowe).

20 Ang. audio-visual item, które nie jest utworem w rozumieniu ACA.

${ }^{21}$ Co czyni się podobnie jak w przypadku fair use (zob. dalszą część niniejszego artykułu), tj. np. badając naturę chronionego utworu czy wpływ korzystania na jego wartość ekonomiczna (rynek).

${ }^{22}$ Reasumujac, możliwe jest zwielokrotnianie dzieła, ale - w analizowanym przypadku - wyłącznie w celach naukowych, o ile będzie to sprawiedliwe (tj. np. pod warunkiem nieodnoszenia korzyści majątkowych), i o ile użytkownik nie skopiuje więcej niż 10\% stron lub słów albo nie więcej niż 1 rozdział (w zależności od tego, czy publikacja nastąiła w formie tradycyjnej, czy elektronicznej).

${ }^{23}$ Od kilku lat Australijczycy rozważają możliwość wprowadzenia systemu fair use, zob. https://en.wikipedia.org/wiki/History_of_fair_use_proposals_in_Australia [Data dostępu: 14 listopada 2017 r.]. 


\section{Fair use}

Rozwinięta w prawie amerykańskim instytucja fair use zawiera bardzo uniwersalne sformułowania, które - w pewnym uproszczeniu - zezwalają na wszelką formę eksploatacji wszystkich utworów (niezależnie od ich rodzaju), byleby działanie użytkownika było sprawiedliwe, czyli „nie pomniejszało uprawnień twórcy”24. Niewątpliwą zaleta fair use jest fakt, że obowiązujące przepisy nie traca na aktualności ${ }^{25}$, mimo rozwoju techniki ${ }^{26}$ oraz zmieniających się norm i oczekiwań społecznych ${ }^{27}$. Jednakże sprawiedliwy użytek nie daje jednoznacznej odpowiedzi, czy danego rodzaju działanie podejmowane przez użytkownika w stosunku do utworu nie stanowi naruszenia prawa autorskiego. Wprowadza więc swego rodzaju niepewnośćc ${ }^{28}$ wśród adresatów prawa, a zwłaszcza mogacych naruszyć prawo autorskie użytkowników ${ }^{29}$. Nieostre sformułowania powodują bowiem, że w praktyce o tym, czy konkretna eksploatacja dzieła była legalna, decyduje dopiero sąd. Sytuacji tej nie upraszcza również brak definicji legalnej sprawiedliwego użytku.

Instytucja fair use $\mathrm{w}$ pewnym sensie zbliżona jest do konstrukcji wspomnianego wcześniej testu trójstopniowego, w tym do treści art. 35 ustawy z dnia 4 lutego $1994 \mathrm{r}$. o prawie autorskim i prawach pokrewnych (tekst jedn. Dz.U. 2018, poz. 1191 z późn. zm. [dalej: PrAut]), z tą jednak różnica, że postanowienia polskiego przepisu stanowia jedynie uzupełnienie pozostałych norm prawnych dotyczących dozwolonego użytku (osobistego i publicznego), podczas gdy rozwiązanie amerykańskie stanowi regulację samodzielną, dotycząca każdego sposobu korzystania z utworu bez zgody twórcy ${ }^{30}$.

Aby użytkownik mógł powołać się na sprawiedliwy użytek, musi spełnić określone przesłanki wskazane w § 107 amerykańskiej ustawy

${ }^{24}$ M. Wilkowska: Wybrane zagadnienia zwiazane z pobieraniem nielegalnych kopii utworów z Internetu. „Przegląd Prawa Handlowego” 2007, T. 13. LEX, s. 23-30.

${ }_{25}$ Treść §107 amerykańskiego The Copyright Act, który stanowi o instytucji fair use, została uchwalona w 1976 r., a od tego czasu była zmieniania merytorycznie jedynie raz w 1992 r., przez dodanie ostatniego zdania o możliwości korzystania z utworu niezależnie od jego wcześniejszego rozpowszechnienia; § 107 Limitations on exclusive rights: Fair use. Westlaw 2017.

${ }^{26}$ J. Preussner-Za morska: Dozwolony użytek..., s. 541-542.

${ }^{27}$ A. Wiebe: Przyszłość prawa informacyjnego. W: „Zeszyty Naukowe Uniwersytetu Jagiellońskiego". Z. 2. Kraków 2008. LEX, s. 5-17.

${ }_{28}$ G.W. Austin: Four questions..., s. 614.

29 Zob. M.W. Carroll: Fixing fair use. „North Carolina Law Review” May 2007. Westlaw.

30 J. Barta, R. Markiewicz: Trzystopniowy test..., s. 15. 
o prawie autorskim ${ }^{31}$, który stanowi, że „niezależnie od postanowień $\S 106$ i $\S 106 \mathrm{~A}^{32}$ sprawiedliwy użytek chronionego utworu, w tym tworzenie kopii lub powielanie fonogramów albo korzystanie [z utworu] w inny sposób określony w tych paragrafach, w celach ${ }^{33}$ takich, jak krytyka, wyjaśnienie, relacja z wydarzeń, nauczanie (w tym wielokrotne kopiowanie do użytku w klasie), nauka lub badania, nie stanowi naruszenia prawa autorskiego. Przy ustalaniu, czy korzystanie z utworu w konkretnym przypadku jest sprawiedliwym użytkiem, należy uwzględnić następujące czynniki:

1) cel i charakter użytku, w tym okoliczność, czy taki użytek ma cel komercyjny, czy też niezarobkowy cel edukacyjny;

2) naturę [charakter] chronionego utworu;

3) ilość i istotność wykorzystanej części [utworu] w stosunku do całości chronionego utworu

4) oraz wpływ użytku na [wielkość] potencjalnego rynku chronionego utworu lub wartość chronionego utworu" ${ }^{34}$.

Co ciekawe, wcześniejsze rozpowszechnienie utworu, w przeciwieństwie do prawa polskiego, nie jest warunkiem koniecznym do uznania, że dana eksploatacja była sprawiedliwa i tym samym nie naruszyła autorskich praw majątkowych ${ }^{35}$.

Badajac, czy dany przypadek korzystania z utworu jest sprawiedliwy, należy zawsze brać pod uwagę łącznie wszystkie cztery przytoczone wyżej kryteria ${ }^{36}$. Ciężar dowodu spoczywa w tym zakresie na użytkowniku, który musi wykazać, że jego postępowanie mieściło się w ramach fair $u s e^{37}$. Jednocześnie nie można z góry przyjmować, że któraś z przesłanek jest bardziej istotna od pozostałych, a zatem istnienie jakiejśs okoliczności przesądza o tym, że dany użytek jest lub nie jest sprawiedliwy ${ }^{38}$. $\mathrm{Na}$ przykład odnoszenie korzyści majątkowych z eksploatacji dzieła nie wy-

${ }^{31}$ The Copyright Act, https://www.copyright.gov/title17/92chap1.html [Data dostępu: 7 listopada 2017 r.].

32 Przepisy te dotyczą praw wyłącznych twórcy.

${ }^{33}$ Wymienione w przytoczonym przepisie cele mają charakter jedynie przykładowy; zob. G.W. Austin: Four questions..., s. 613.

${ }_{34}$ Tłumaczenie Є.M.

${ }_{35}$ Zob. $\$ 107$ in fine: ,sam fakt, że utwór nie został opublikowany nie wyklucza uznania użytku za sprawiedliwy, o ile wynika to z rozważenia wszystkich powyższych czynników". [Tłum. — Ł.M.].

${ }^{36}$ S. Siskind: Crossing the fair use line: The demise and revival of the Harry Potter lexicon and its implications for the fair use doctrine in the real world on the Internet. „Cardozo Arts and Entertainment Law Journal” 2009. Westlaw, s. 297.

${ }^{37}$ M.J. Madison: A pattern-oriented approach to fair use. „William and Mary Law Review", March 2004. Westlaw, s. 1552.

${ }^{38}$ S. Siskind: Crossing the fair use line..., s. 296-297. 
łącza automatycznie możliwości zakwalifikowania takiego korzystania jako mieszczacego się w zakresie fair $u s e^{39}$.

1. Cel i charakter korzystania z utworu. W przypadku analizy eksploatacji dzieła w kontekście pierwszej ustawowej przesłanki należy dokonać oceny, czy podjęte czynności polegały na twórczej „transformacji” utworu pierwotnego, czy też prowadza jedynie do „zastąienia” orygina$\nmid u^{40}$. Innymi słowy, niewątpliwie bardziej sprawiedliwy jest użytek polegający na przerobieniu dzieła, czyli wykorzystaniu go do stworzenia czegoś nowego, np. parodii. Jeśli zaś eksploatacja polega jedynie na powieleniu utworu, np. skopiowaniu go, bądź przynosi użytkownikowi jakieś korzyści majątkowe, to wprawdzie nie przekreśla to jeszcze zakwalifikowania korzystania jako fair use, jednak w takim przypadku większą rolę zaczynają odgrywać pozostałe trzy czynniki ${ }^{41}$.

2. Natura chronionego utworu. Przy ocenie tego kryterium należy analizować dwie kwestie ${ }^{42}$. Po pierwsze, stopień „twórczości” utworu, którego dotyczy eksploatacja - łatwiej będzie powołać się na fair use, gdy dzieło stanowi materiał informacyjny lub oparte jest na faktach (tzn. odwzorowaniu rzeczywistości), a trudniej, gdy jest zupełnie nowym wytworem (np. fikcją literacka). Po drugie, istotne jest, czy dzieło zostało rozpowszechnione za zgodą twórcy - choć, jak już wskazano, brak udostępnienia utworu publiczności nie przekreśla sprawiedliwości użytku.

3. Ilość i istotność wykorzystanej części utworu. Trzecia przesłanka fair use jest szczególnie interesująca, gdyż przyjmuje bardzo ocenny charakter i wyraźnie odróżnia omawianą instytucję od fair dealing i dozwolonego użytku. W przedstawionej wcześniej doktrynie sprawiedliwego postępowania przepisy prawa dokładnie i szczegółowo określaja, jakiego rodzaju działania można podjać w stosunku do danego utworu, czasami wskazując nawet, jaka część dzieła może być przedmiotem eksploatacji (zwielokrotnienia). Dozwolony użytek ${ }^{43}$ również opisuje konkretne rodzaje dozwolonych czynności (np. prawo cytatu, możliwość korzystania z utworu na użytek własny). Tymczasem fair use nie określa z góry, chociażby przy pewnych założeniach, jakie działania nie będą naruszały prawa autorskiego. Teoretycznie może się więc okazać, że w niektórych sytuacjach legalne będzie skopiowanie nawet całego dzieła, a w innych za bezprawne zostanie uznane zwielokrotnienie 5\% jego treści. Co więcej, ważna jest nie tylko ilość utworu objęta eksploatacja, ale także istotność

${ }^{39}$ Zob. materiały legislacyjne Izby Reprezentantów Notes of Committee on the Judiciary, House Report No. 94-1476, General Background of the Problem. Westlaw, s. 66.

${ }^{40}$ M.W. Carroll: Fixing fair use..., s. 1102.

${ }^{41}$ S. Siskind: Crossing the fair use line..., s. 297.

${ }^{42}$ Ibidem, s. 298.

${ }^{43}$ Zob. rozważania w dalszej części niniejszej pracy. 
wykorzystanej części, którą to istotność można rozumieć zarówno jako fragment charakteryzujący się największym poziomem wkładu twórczego, jak i fragment stanowiący najwyższą wartość ekonomiczna ${ }^{44}$.

4. Wpływ eksploatacji na wartość utworu i jego rynek. Ostatnia przesłanka skupia się przede wszystkim na ochronie ekonomicznych interesów twórcy. W praktyce jurydycznej kryterium to uważane jest niekiedy (chociaż niesłusznie) za najważniejsze z czterech ustawowych czynników ${ }^{45}$. Szczegółowa analiza tej przesłanki wykracza poza ramy niniejszego artykułu. Należy tu jedynie wskazać, że działanie użytkownika wyrządza szkodę na „rynku” danego utworu jedynie wtedy, gdy „zastępuje" korzystanie z oryginału przez osoby trzecie ${ }^{46}$ (vide: pierwsze kryterium) ${ }^{47}$. I tak dostępna w serwisie YouTube parodia Trolling Saruman ${ }^{48}$ mieści się, moim zdaniem, w zakresie fair use, nawet biorac pod uwagę fakt, że wkład twórczy (stopień transformacji oryginałów) jest w tym przypadku niewielki ${ }^{49}$, i jeśli jej autor odnosi z niej korzyści majątkowe, gdyż w żaden sposób powstała „przeróbka” nie wyrządza ekonomicznej szkody dziełom pierwotnym (wręcz przeciwnie - może stanowić dla nich swoista reklamę).

Podsumowując rozważania na temat fair use, należy podkreślić, że mimo wielu zalet, jakie niesie z sobą ta instytucja, zwłaszcza w postaci ponadczasowej uniwersalności użytych sformułowań, jej stosowanie w praktyce może stwarzać wiele realnych problemów. Dlatego też wydaje się, że jej ewentualna implementacja do polskiego czy też europejskiego porządku prawnego nie jest zasadna - zwłaszcza biorąc pod uwage odmienność obowiąującego w Stanach Zjednoczonych systemu common law. Niemniej jednak fair use stanowi kolejny dowód na to, że nie każde korzystanie $\mathrm{z}$ utworu $\mathrm{w}$ Internecie bez zgody twórcy jest naruszeniem prawa autorskiego, wręcz przeciwnie: eksploatacja dzieła tak długo nie narusza prawa, jak długo pozostaje sprawiedliwa, czyli ogólnie rzecz ujmując — nie godzi w słuszne interesy autora.

${ }^{44}$ M.J. Madison: A pattern-oriented approach..., s. 1561.

${ }_{45}$ M.W. Carroll: Fixing fair use..., s. 1105.

${ }^{46}$ S. Siskind: Crossing the fair use line..., s. 300.

${ }^{47}$ Choć można także argumentować, że szkodę na rynku wyrządza samo jednostkowe działanie użytkownika, np. jeśli internauta ściągnął utwór z Sieci, to nie dokona jego zakupu; por. M.J. Madison: A pattern-oriented approach..., s. 1562-1563.

${ }^{48} \mathrm{https} / / / \mathrm{www} . y o u t u b e . c o m / w a t c h ? v=K a q C 5 F n v A E c$ [Data dostępu: 9 listopada 2017 r.].

${ }^{49}$ Parodia jest w rzeczywistości kompilacja fragmentu filmu Władca Pierścieni: Powrót króla i jednej z radzieckich piosenek sprzed kilkudziesięciu lat. 


\section{Dozwolony użytek}

Można stwierdzić, że dozwolony użytek to rozwiązanie pośrednie pomiędzy fair dealing a fair use. Podobnie jak w doktrynie sprawiedliwego postępowania, dozwolony użytek, zwłaszcza publiczny, zawiera normy prawne jasno wskazujące, jakiego rodzaju czynności i w jakich sytuacjach można podjać w stosunku do utworów (a czasami nawet do utworów konkretnego rodzaju). Jednakże niektóre przepisy sa sformułowane abstrakcyjnie, przybierają formę bardziej uniwersalną, co zbliża przyjęte rozwiąania do instytucji fair use.

W kontekście korzystania z utworów w Internecie największe znaczenie ma dozwolony użytek osobisty ${ }^{50}$, uregulowany $\mathrm{w}$ prawie polskim w art. 23 PrAut ${ }^{51}$. Przepis ten sformułowany jest w sposób abstrakcyjny, dopuszcza bowiem w zasadzie każdą formę korzystania z dzieła ${ }^{52}$, a zatem jego zwielokrotnianie (kserowanie, skanowanie, przegrywanie), konwertowanie, użyczanie i ogólne eksploatowanie (odtwarzanie, oglądanie, czytanie - w zależności od rodzaju dzieła), jeśli tylko wymienione czynności następują w „kręgu osób pozostających w związku osobistym”53. Warunkiem koniecznym, który musi zostać spełniony, aby móc się powołać na dozwolony użytek osobisty, jest wcześniejsze rozpowszechnienie utworu za zgodą twórcy ${ }^{54}$. Zasadniczo w doktrynie przyjmuje się rów-

${ }^{50}$ Choć niewątpliwie istotne będą również przepisy z zakresu dozwolonego użytku publicznego, dotyczące np. prawa cytatu (art. 29 PrAut) czy parodii (art. $29^{1}$ PrAut).

${ }^{51}$ Zgodnie z którym: „1. Bez zezwolenia twórcy wolno nieodpłatnie korzystać z już rozpowszechnionego utworu w zakresie własnego użytku osobistego. Przepis ten nie upoważnia do budowania według cudzego utworu architektonicznego i architektoniczno-urbanistycznego oraz do korzystania z elektronicznych baz danych spełniających cechy utworu, chyba że dotyczy to własnego użytku naukowego niezwiązanego z celem zarobkowym.

2. Zakres własnego użytku osobistego obejmuje korzystanie z pojedynczych egzemplarzy utworów przez krąg osób pozostających w związku osobistym, w szczególności pokrewieństwa, powinowactwa lub stosunku towarzyskiego".

${ }^{52} \mathrm{Z}$ pewnymi wyjątkami, jak np.: budowanie według cudzego utworu architektonicznego, korzystanie z elektronicznych baz danych czy programów komputerowych (por. art. 77 PrAut).

${ }^{53}$ Do kręgu takich osób można zaliczyć nawet podmioty, z którymi użytkownik utrzymuje wyłącznie relacje wirtualne, zob. E. Konopczyńska: Granice..., s. 7. Przy czym należy pamiętać, że relacje te muszą być bliskie. Nie można zatem uznać, że w kręgu osób pozostających w związku osobistym mieszczą się np. wszyscy znajomi z Facebooka.

${ }^{54}$ Nie będzie zatem stanowiło dozwolonego użytku osobistego pobranie z Internetu filmu przed jego oficjalną premierą kinowa, zob. P. Ślęzak: Ustawa o prawie autorskim i prawach pokrewnych. Komentarz. 2017. LEGALIS, art. 23, nb 10. 
nież, że podejmowana eksploatacja nie może przybierać komercyjnego ${ }^{55}$, czyli odpłatnego ${ }^{56}$ charakteru $^{57}$. Dozwolony użytek osobisty obejmuje korzystanie jedynie z „pojedynczych egzemplarzy utworów”. Sformułowanie to jest nieprecyzyjne ${ }^{58} \mathrm{i}$, moim zdaniem, nie do końca niezbędne wobec całokształtu postanowień art. 23 PrAut. Można jednak uznać, że wyraża intencję ustawodawcy, aby zwielokrotnianie dzieł w ramach dozwolonego użytku osobistego nie przybierało masowej (nieograniczonej) skali ${ }^{59}$.

Analizując treść art. 23 PrAut wraz z pozostałymi postanowienia ustawy (w szczególności art. 35 PrAut), należy stwierdzić, że w środowisku internetowym dopuszczalne jest korzystanie z utworu w ramach tzw. browsingu $^{60}$, streamingu ${ }^{61}$, downloadingu ${ }^{62}$ oraz linkingu ${ }^{63}$, jeśli następuje to w kręgu osób bliskich (krewnych, powinowatych, bliskich znajomych) i nie narusza normalnego korzystania z utworu (art. 35 PrAut) ${ }^{64}$. Niedozwolone jest natomiast ściaganie plików za pomoca sieci peer-to-peer ${ }^{65}$ (gdyż z jednoczesnym pobieraniem danych następuje ich udostępnianie) oraz uploadowanie ${ }^{66}$ treści, rozumiane jako rozpowszechnianie

${ }^{55}$ Ibidem, art. 23, nb 7.

${ }^{56} \mathrm{~K}$. Gienas, w: Ustawa o prawie autorskim i prawa pokrewnych. Komentarz. Red. E. Ferenc-Szydełko. 2016. LEGALIS, art. 23, nb 20.

${ }^{57}$ Choć nie można tej zasady rozumieć w sposób absolutny. Wszak skopiowanie utworu albo pobranie go z Internetu powoduje, że użytkownik odnosi korzyść majątkowa nie kupuje bowiem egzemplarza dzieła w księgarni. Okoliczność ta nie wyłącza jednak możliwości powołania się na dozwolony użytek osobisty.

${ }^{58}$ E. Konopczyńska: Granice..., s. 6-7.

59 Ibidem, s. 7; J. Preussner-Za morska: Dozwolony użytek..., s. 537.

${ }^{60}$ Browsing - przeglądanie Internetu za pośrednictwem przeglądarki internetowej, od ang. web browser, https://en.wikipedia.org/wiki/Web_browser [Data dostępu: 25 listopada 2017 r.].

${ }^{61}$ Streaming - oglądanie materiałów wideo lub audio dostępnych w Internecie bez trwałego ściągania ich do pamięci urządzenia, https://en.wikipedia.org/wiki/Streaming media [Data dostępu: 25 listopada 2017 r.].

62 Downloading - ściąganie materiałów dostępnych w Internecie do pamięci urządzenia, https://en.wikipedia.org/wiki/Download [Data dostępu: 25 listopada 2017 r.].

${ }^{63}$ Linking - udostępnianie w Internecie linków, których kliknięcie powoduje, że zostajemy przekierowani do strony, na której możemy zapoznać się z danym materiałem, https://en.wikipedia.org/wiki/Hyperlink [Data dostępu: 25 listopada 2017 r.].

${ }^{64}$ Więcej o korzystaniu z utworów w Internecie w ramach browsingu, streamingu, downloadingu, linkingu, sieci peer-to-peer oraz uploadingu, zob. Ł. Maryniak: Ściaganie i udostępnianie plików $w$ Internecie. W: Czego nie wolno robić $w$ Internecie. Poradnik dla blogerów, vlogerów i instagramowiczów. Red. K. Grzybczyk. 2017, s. 103 i nast.

${ }_{65}$ Peer-to-peer - szczególne połączenie sieciowe, umożliwiające wymianę (pobieranie) danych z Internetu, https://pl.wikipedia.org/wiki/Peer-to-peer [Data dostępu: 25 listopada 2017 r.].

${ }^{66}$ Uploading - przesyłanie danych do Internetu lub za pomoca Internetu (na serwer lub bezpośrednio do komputera innego użytkownika), https://pl.wikipedia.org/wiki/ Upload [Data dostępu: 25 listopada 2017 r.]. 
utworu potencjalnie nieograniczonemu gronu odbiorców (wszystkim internautom).

W kontekście działania internetowych trolli istotnym zagadnieniem jest kwestia ewentualnego imperatywnego charakteru dozwolonego użyt$\mathrm{ku}$ osobistego, sprowadzająca się do odpowiedzi na pytanie, czy przyznane użytkownikom uprawnienia do korzystania z utworów bez zgody twórcy można wyłączyć albo ograniczyć moca czynności prawnej (w tym jednostronnej) lub na skutek czynności faktycznej (np. przez wprowadzenie zabezpieczeń $\left.\mathrm{DRM}^{67}\right)^{68}$. Mając na względzie ogólną zasadę swobody umów, wyrażona w art. $353^{1}$ ustawy z dnia 23 kwietnia 1964 r. - Kodeks cywilny (tekst jedn. Dz.U. 2018, poz. 1025 z późn. zm. [dalej: k.c.]), należy dopuścić teoretyczną możliwość ograniczenia, a nawet wyłączenia dozwolonego użytku osobistego na mocy umowy pomiędzy podmiotem autorskouprawnionym a przyszłym użytkownikiem ${ }^{69}$, przy czym w praktyce skuteczność takich postanowień będzie znikoma, gdyż w przypadku najczęstszej masowej dystrybucji egzemplarzy utworów umowy zawierane z odbiorcą dzieła mają charakter adhezyjny ${ }^{70}$. Tymczasem należy mieć na względzie, że niekorzystne dla konsumenta postanowienia umowy nie będa go - co do zasady — wiązać, jeżeli nie zostały uzgodnione indywidualnie (por. art. $385^{1}$ k.c.) ${ }^{71}$. Nie mają zatem mocy prawnej wszelkiego rodzaju oświadczenia na egzemplarzach dzieł, jak np. „kopiowanie lub użyczanie płyty CD jest zabronione”. Niedopuszczalne będzie również wyłączenie lub ograniczenie przysługujących użytkownikowi uprawnień na mocy jednostronnej czynności prawnej bądź na skutek wprowadzenia systemu zabezpieczeń $\mathrm{DRM}^{72}$. Nie po to bowiem ustawodawca wyraźnie

${ }^{67} \mathrm{O}$ systemie DRM zob. https://pl.wikipedia.org/wiki/Zarz\%C4\%85dzanie_prawa mi_cyfrowymi [Data dostępu: 11 listopada 2017 r.].

${ }^{68}$ Expressis verbis możliwość wyłączenia dozwolonego użytku osobistego przyjęto w niektórych państwach EU, jak Portugalia czy Belgia; zob. K. Gienas: Imperatywny charakter dozwolonego użytku prywatnego? „Zeszyty Naukowe Uniwersytetu Jagiellońskiego. Prace z Prawa Własności Intelektualnej” 2009, z. 4, s. 21.

69 Tak ibidem, s. 27.

${ }^{70}$ Nabywając egzemplarz utworu, nabywcy zazwyczaj nie negocjują postanowień umowy, gdyż nie mają takiej możliwości — kupując płytę DVD w sklepie, można ją nabyć wyłącznie na „warunkach” określonych przez dystrybutora, a więc np. z zainstalowanym systemem DRM.

${ }^{71}$ Zob. K. Grzybczyk: Zasada swobody umów a ograniczenia dozwolonego użytku chronionych utworów. W: Ustawowe ograniczenia swobody umów. Zagadnienia wybrane. Red. B. Gnela. Warszawa 2010, s. 226.

72 Warto zwrócić uwagę, że ustawodawca w art. 79 ust. 6 PrAut przyznał uprawnionemu z tytułu autorskich praw majątkowych roszczenia przeciwko osobie, która obchodzi lub usuwa zastosowane zabezpieczenia techniczne (np. uniemożliwiające skopiowanie utworu), jednakże tylko wtedy, gdy takie działanie użytkownika ma na celu „bezprawne korzystanie z utworu". 
stwierdza w art. 23 ust. 1 PrAut, że „wolno [...] korzystać z [...] utworu” (w zakresie dozwolonego użytku osobistego), aby uprawnienie to było następnie przez twórcę lub jego następcę prawnego wyłączane - wypaczałoby to bowiem w ogóle sens wprowadzenia omawianej instytucji.

\section{Podsumowanie}

Można różnie oceniać omówione (w dużym skrócie) w niniejszym artykule instytucje upoważniające internautów do korzystania z utworów bez zgody ich autorów. Wspólnym mianownikiem wszystkich rozwiązań jest jednak dążenie do wyważenia spornych interesów twórców i użytkowników. Ustawodawcy różnych państw dostrzegają z jednej strony konieczność zdecydowanej ochrony ekonomicznych aspektów prawa autorskiego (w tym zapewnienia twórcom godziwego wynagrodzenia), z drugiej strony jednak zgadzają się, że w dobie Internetu i środowiska cyfrowego nie sposób całkowicie wyłączyć (tj. uznać za bezprawne) wykorzystywania utworów dostępnych w sieci bez zgody ich autorów. Z różnych regulacji z zakresu prawa autorskiego obowiązujacych na świecie zdaje się wypływać jeden wniosek — „wrogiem” twórców jest przede wszystkim ten, kto bezprawnie udostępnia (rozpowszechnia) w Internecie utwory. Taka osobę istotnie można uznać za „pirata”73. Znacznie mniejszą winę (w znaczeniu potocznym) ponosi natomiast ten, kto jedynie korzysta z zasobów, które ktoś wcześniej umieścił w sieci. Rozstrzygnięcie, czy taki użytkownik w ogóle naruszył autorskie prawa majątkowe, nie zawsze jest oczywiste, a w każdym razie wymaga głębokiej analizy (zazwyczaj licznych) przepisów wprowadzających wyjątki od zasady wyłączności praw autorskich, czego oczywiście brakuje w działalności internetowych trolli.

${ }^{73}$ Zob. pojęcie „piractwo medialne”, https://pl.wikipedia.org/wiki/Piractwo_medial ne [Data dostępu: 14 listopada 2017 r.]. 


\title{
Aleksandra Drapała*
}

\section{Parental trolling w świetle uregulowań polskiej ustawy karnej}

\begin{abstract}
With respect to a relatively young - new - term of 'parental trolling', an important problem arises in terms of parents' liability, including penal liability, for publishing information relating to their children.

Lack of clear regulations relating to the liability for actions classified as actions that form part of the constituent elements of parental trolling in the Penal Code calls for the need to classify individual actions with reference to circumstances, to the parent's intention, and most of all to the published information. In terms of the Polish penal law, the fundamental question remains what constituent elements of which offences may be fulfilled in specific circumstances. Besides the legal classification of the offence, an equally important issue is that of the prosecution procedure.

The paper aims to present what types of behaviour constitute elements of broadly grasped parental trolling, as well as to demonstrate, describe, and analyse the regulations of the Penal Code which provide the legal basis to hold a parent liable for publishing information classified as parental trolling. Furthermore, the paper also touches upon an equally crucial issue, namely who is authorised to represent a minor victim in court proceedings against their parent, as well as whether activities on behalf of the minor can be performed by the other parent, or whether such representation is excluded.
\end{abstract}

Keywords: parental trolling, penal law, parents' liability, penal liability, representation a minor victim

${ }^{1}$ Mgr, Uniwersytet Ślasski w Katowicach. 


\section{Zamiast wstępu}

Współcześnie, z uwagi na rozwój społeczeństwa, doświadczamy coraz dalej idącej wirtualizacji czy też digitalizacji życia. Obecnie z rodziną i znajomymi w większości komunikujemy się internetowo - czy to za pomoca komunikatorów, czy też przez szeroko rozumiane social media. Częstszy wybór interakcji za pośrednictwem komputera aniżeli kontaktu bezpośredniego nierzadko staje się przedmiotem badań naukowych. Podstawowy wniosek z dotychczas przeprowadzanych badań jest niezwykle klarowny - interakcja za pomoca sieci jest o wiele łatwiejsza, nie wymaga zaangażowania poznawczego ani emocjonalnego, które towarzyszą kontaktom bezpośrednim i wymagają od nas przetwarzania sygnałów komunikacji niewerbalnej, stanowiącej znacząca część kontaktów face-to-face ${ }^{1}$. Kontakty online sa dla nas mniej wymagajace, pozbawione emocji, umożliwiaja dokonywanie w tym samym czasie wielu innych czynności ${ }^{2}$. W przypadku kontaktów za pośrednictwem portali społecznościowych dodatkowo trafiamy do szerszego grona odbiorców. Niejednokrotnie też możemy się spotkać z zachowaniami daleko idącego ekshibicjonizmu, nietrudno bowiem natknąc się na wpisy i publikacje o charakterze intymnym w szeroko rozumianym znaczeniu. Badania rynku pokazuja, że globalnie około $24 \%$ użytkowników portali społecznościowych deklaruje, że dzieli się wszystkim lub prawie wszystkim za pośrednictwem social mediów, natomiast około $19 \%$ wskazuje, że nie publikuje żadnych treści ${ }^{3}$. Jakie konsekwencje pociąga za soba publikowanie w sieci, w szczególności gdy wpisy dotyczą osób trzecich, również dzieci? W niektórych krajach, $\mathrm{w}$ tym także w Polsce, przeprowadzane są kampanie uświadamiajace, że korzystanie z Internetu przez małoletnich może wiązać się z wieloma niebezpieczeństwami ${ }^{4}$. Jednak czy rodzice także sa świadomymi użytkownikami sieci? Również rodziców (przede wszystkim młodych) należy edukować w zakresie niebezpieczeństwa płynącego z publikowania określonych treści, głównie za pośrednictwem mediów społecznościowych, ze szczególnym wyróżnieniem treści dotyczących ich własnych dzieci. Nie są

${ }^{1}$ L. Margalit: The psychology behind social media interactions, https://www.psycho logytoday.com/blog/behind-online-behavior/201408/the-psychology-behind-social-mediainteractions/ [Data dostępu: 6 października 2017 r.].

${ }^{2}$ Ibidem.

${ }^{3}$ C. Seiter: 7 Social Media Psychology Studies That Will Make Your Marketing Smarter,https://blog.bufferapp.com/social-media-psychology-studies-smarter-marketing/ [Data dostępu: 6 października 2017 r.].

${ }^{4}$ Zob. Kampania Chroń dziecko w sieci, http://www.dzieckowsieci.pl/kampania/ [Data dostępu: 6 października 2017 r.]. 
oni bowiem świadomi, że każde publikowane przez nich zdjęcie czy film pozostawia elektroniczny ślad, którego nie można „wymazać”, nawet gdy treść ma trafić jedynie do ograniczonej liczby odbiorców. I tak np. na popularnym portalu Facebook, gdzie ustawienia profilu użytkownika pozwalają na ograniczenie odbiorców publikowanych wiadomości (postów) do określonej grupy znajomych, zaobserwować można, że niewiele osób korzysta z takich funkcji. W konsekwencji informacje publikowane przy ustawieniu publiczne trafiają do nieograniczonej liczby odbiorców - nie tylko znajomych. Usunięcie zdjęcia czy też filmu z własnego profilu nie skutkuje bowiem usunięciem danej treści z zasobów sieci. Jaką odpowiedzialność ponosimy za publikowane treści, w szczególności gdy dotyczą one naszych dzieci?

\section{Słów kilka o trollowaniu}

Zmierzając do zdefiniowania, czym jest parental trolling, należy wyjść od definicji osoby określanej mianem trolla. Pojęcie troll w interesującym nas znaczeniu ukształtowało się wraz z rozwojem samego Internetu i powszechności dostępu do sieci. Mianem trolla określamy osobę, która zamieszcza w sieci komentarze i treści o charakterze prześmiewczym, irytującym, mającym na celu zwrócenie uwagi odbiorców ${ }^{6}$. Tym samym trollowaniem możemy nazwać wszelkie zachowania spełniające wymienione przesłanki. Na tej podstawie, określając, czym jest parental trolling, musimy sprecyzować podmiot dokonujący czynności o znamionach trollingu, jak również przedmiot tych czynności. Podmiotem sprawczym parental trollingu stają się rodzice w sytuacji wykorzystywania wizerunku swojego dziecka (przedmiot parental trollingu) utrwalonego w sytuacjach je kompromitujących lub ośmieszających, przy czym wykorzystanie następuje przez upowszechnianie tego wizerunku online w celu zwrócenia uwagi i uzyskania szerokiego grona odbiorców. Z pozoru niewinne zachowanie rodzica, który chcąc podzielić się ze znajomymi śmieszna sytuacją wywołaną zachowaniem dziecka, publikując zdjęcie lub film opatrzony stosownym komentarzem, de facto staje się sprawca

${ }_{5}^{5}$ Is it safe to post pictures of my kid online?, https://www.commonsensemedia.org/ privacy-and-internet-safety/is-it-safe-to-post-pictures-of-my-kid-online/ [Data dostępu: 6 października 2017 r.].

${ }_{6}$ Troll, http://dictionary.cambridge.org/dictionary/english/troll/[Data dostępu: 6 października 2017 r.]. 
cyberprzemocy, której nie jest świadomy, a która może rzutować w przyszłości na osobę dziecka, którego wizerunek został naruszony. Publikując jakiekolwiek treści w Internecie, trzeba mieć na uwadze, że od momentu wprowadzenia ich do sieci nie mamy wpływu na ich dalszy los ani na grupę odbiorców, którzy do treści tych mogą dotrzeć. Jeśli chodzi o filmiki i zdjęcia (najczęściej śmieszne), których autorami sa rodzice, głównymi aktorami zaś dzieci, to należy podkreślić, że rodzice wykorzystując bezradność dziecka budują w ten sposób swoja pozycję w mediach społecznościowych, gdzie publikowane przez nich treści zdobywaja laj$k i$ i sa udostępniane dalej, trafiajac tym samym do bliżej nieokreślonej liczby odbiorców. Zdobycie poklasku wśród innych użytkowników social mediów stanowi z kolei motor napędowy dalszych działań rodzica, wypełniajacych znamiona parental trollingu.

Podsumowując, parental trolling to świadome nadużywanie wizerunku dziecka uchwyconego w kompromitujacej lub ośmieszającej sytuacji i publikowanie go przez rodzica w celu zdobycia popularności online ${ }^{7}$.

\section{Polskie uregulowania prawnokarne}

Przepisy regulujace odpowiedzialność karną w polskim systemie prawnym nie definiuja pojęcia parental trolling. Należy wskazać, że każdorazowo w przypadku publikowania przez rodzica treści wykorzystujacych wizerunek dziecka, a stanowiących jego ośmieszenie lub kompromitację, należy takie zachowanie badać pod kątem wystapienia przesłanek odpowiedzialności karnej na podstawie obowiązujących przepisów. Małoletni, choć chronieni w sposób szczególny przez przepisy prawa, jeśli chodzi o przemoc kwalifikowana jako parental trolling, nie otrzymali jeszcze szczególnej - wyróżnionej ochrony.

W przypadku rozważania ewentualnej odpowiedzialności karnej rodzica z tytułu czynu, który można kwalifikować jako parental trolling, każdorazowo konieczna jest analiza okoliczności, jak i treści publikowanych przez rodzica-trolla filmów i zdjęć z wykorzystaniem wizerunku swojego dziecka w odniesieniu do obowiąujaccych przepisów.

Ponieważ do rozwoju parental trollingu dochodzi głównie dzięki powszechności dostępu do Internetu, w odniesieniu do rodziców-trolli trzeba brać pod uwage przepisy stosowane wobec trolli internetowych

${ }^{7}$ Parental trolling - Rodzicu, pomyśl zanim udostępnisz, http://ocaleni.org/2016/ 11/27/parental-trolling/ [Data dostępu: 17 listopada 2017 r.]. 
— art. 190a, 212 i 216 k.k. ${ }^{8}$ Analizujacc przepisy Kodeksu karnego w odniesieniu do najczęściej pojawiających się w sieci treści, możemy wstępnie wyróżnić odpowiedzialność na podstawie art. 191a k.k. oraz art. 216 k.k., których szczegółowa analiza została przedstawiona poniżej. W odniesieniu do pozostałych przepisów mogacych mieć zastosowanie wobec trolli internetowych - stalkingu i zniesławienia - ze względu na ich specyfikę trudno wyobrazić sobie, by rodzic wobec własnego dziecka miał popełniać czyny kwalifikowane jako tego rodzaju przestępstwa.

\section{Utrwalanie i rozpowszechnianie nagich zdjęć i filmów}

Pierwszy z powołanych przepisów - art. 191a k.k. - wprowadzony nowelizacja ustawy Kodeks karny, która weszła w życie 8 czerwca 2010 r., dotyczy m.in. odpowiedzialności za rozpowszechnianie wizerunku nagiej osoby bez jej zgody.

Na gruncie przytaczanego przepisu pod pojęciem „nagość” należy rozumieć całkowite bądź częściowe pozbawienie odzieży w sposób powodujący obnażenie, odsłonięcie narządów płciowych, pośladków, a w przypadku kobiet także piersi ${ }^{9}$. Przedmiotem ochrony w szerokim znaczeniu pozostaje wolność człowieka dysponowania swoim wizerunkiem w zwiazku z intymną sferą jego życia ${ }^{10}$. Zakreślając podmiotowy przedmiot czynności sprawczej, ustawodawca ograniczył się do określenia, że jest nim osoba $^{11}$ - w znaczeniu osoby fizycznej, czyli istoty żyjącej od chwili narodzin do chwili śmierci. W doktrynie spotkać można podzielone poglady $\mathrm{w}$ zakresie ograniczenia wiekowego pokrzywdzonego, a mianowicie od jakiego momentu — osiagnięcia jakiego wieku — człowiek w stanie nagości staje się przedmiotem ochrony w ujęciu wymienionego przepisu. Jak wskazuje T. Bojarski, „Kwestia ta dotyczy zarówno czynnika obiek-

${ }^{8}$ M. Domagalski: Trolle nie musza rzadzić internetem, http://www.rp.pl/Inter net/306309842-Trolle-nie-musza-rzadzic-internetem.html\#ap-2/ [Data dostępu: 8 października 2017 r.].

${ }_{9}$ M. Mozgawa: Komentarz aktualizowany do art. 191(a) Kodeksu karnego. W: Kodeks karny. Komentarz aktualizowany. Red. M. Mozgawa. Warszawa 2017. LEX nr 534479.

10 J. Lachowski: Komentarz do art. 191(a) Kodeksu karnego. W: Kodeks karny. Komentarz. Red. V. Konarska-Wrzos ek. Warszawa 2016. LEX nr 10437.

${ }^{11}$ B. Filek: Wizerunek nagiej osoby jako znamie przestępstwa $z$ art. 191a §a k.k. „Prokuratura i Prawo” 2012, nr 7-8, s. 61. 
tywnego, tj. tego, czy strona przedmiotowa tego przestępstwa obejmuje nagie niemowlę, którego wizerunek został upowszechniony bez zgody ustawowego przedstawiciela dziecka, jak również subiektywnego, z którym wiąże się określenie granicy wieku umożliwiajacej młodej osobie wyrażenie zgody na utrwalanie jej wizerunku lub zachowania określonego w art. 191a k.k."12 Jedno ze stanowisk wskazuje, że w przypadku bardzo małego dziecka nie możemy mówić o wykształceniu wolności decyzyjnej w zakresie własnej intymności, tym samym nie może być mowy o naruszeniach $\mathrm{w}$ tym obszarze, natomiast publikowanie nagich zdjęć niemowlęcia narusza prywatność rodziców, jednak nie stanowi automatycznie naruszenia penalizowanego art. $191 \mathrm{a} \mathrm{k.k.}{ }^{13}$ Odmienne stanowisko znamionuje, że w związku z brakiem ustanowienia przez samego ustawodawcę ograniczenia w zakresie wieku pokrzywdzonego nie można dokonywać interpretacji zawężajacej przepisu, wprowadzając w jego stosowaniu cenzus wiekowy ${ }^{14}$. Trafniejszy wydaje się drugi z przedstawionych poglądów, ponieważ brak wykształcenia wolności decyzyjnej nie powinien być ograniczeniem ochrony płynącej z przepisów prawa, tym samym przedmiotem ochrony na podstawie art. $191 \mathrm{a} \mathrm{k} . \mathrm{k}$. winien być wizerunek osoby bez względu na jej wiek czy też inne przesłanki, jak: rasa, płeć, wyznanie itp.

Wizerunek, zgodnie z definicją Stownika języka polskiego, stanowi czyjąśs podobiznę na rysunku, obrazie, zdjęciu itp., jak również sposób, w jaki dana osoba jest postrzegana i przedstawiana ${ }^{15}$. Omawiany przepis jedynie w części odnosi się do przytoczonej definicji, na gruncie tego uregulowania bowiem wizerunek stanowi podobiznę człowieka, która pozwala na jego identyfikację ${ }^{16}$. Jednak uzasadnione wykładnia celowościowa jest przyjęcie wąskiego rozumienia pojęcia - chodzi tu o zarejestrowanie podobizny za pomoca technicznych środków rejestracji obrazu ${ }^{17}$. Uzasadnione jest to tym, że wprowadzenie niniejszego przepisu spowodowane było m.in. rozpowszechnianiem wizerunków o określonej treści za pośrednictwem Internetu. Istotna przesłanka konieczna do zastosowania art. 191a k.k. jest rozpoznawalność osoby uwiecznionej na zdjęciu czy filmie, nie jest bowiem konieczne, by widoczna była twarz pokrzywdzonego, wystarczy, że np. ze względu na

12 T. Bojarski: Komentarz do art. 191(a) Kodeksu karnego. W: Kodeks karny. Komentarz. Red. T. Bojarski. Wyd. 7. Warszawa 2016. LEX nr 10269.

${ }_{13}^{13}$ M. Mozgawa: Komentarz aktualizowany do art. 191(a) Kodeksu karnego...

14 B. Filek: Wizerunek nagiej osoby jako znamie przestępstwa..., s. 62-63.

15 Wizerunek, http://sjp.pwn.pl/sjp/wizerunek;2579940.html/ [Data dostępu: 7 listopada 2017 r.].

16 J. Lachowski: Komentarz do art. 191(a) Kodeksu karnego...

17 M. Mozgawa: Komentarz aktualizowany do art. 191(a) Kodeksu karnego... 
cechę, element lub utrwalone okoliczności będzie możliwa identyfikacja konkretnej osoby ${ }^{18}$.

W zakresie rozpowszechniania wizerunku osoby nagiej nie ma znaczenia, czy uwieczniono ja za jej zgoda, czy też bez jej zgody. W przypadku niniejszego przepisu istotne jest to, że samo rozpowszechnienie nastapiło bez jej zgody ${ }^{19}$. Na gruncie niniejszego uregulowania rozpowszechnienie rozumiemy jako każde zachowanie zmierzające do zapoznania z wizerunkiem osoby lub osób trzecich ${ }^{20}$. Brak tu jednak przesłanki, by udostępnienie musiało skutkować zapoznaniem się z treścia publikowanego materiału przez bliżej niezdefiniowane nieograniczone grono osób, jak ma to miejsce np. w przypadku rozpowszechniania treści pornograficznych (art. 202 k.k.) ${ }^{21}$. Ze względu na charakter ochrony gwarantowanej przepisem art. 191a k.k. nie jest możliwa zawężająca wykładnia w zakresie przesłanki określonego grona potencjalnych odbiorców rozpowszechnianej treści. Należy podkreślić, że wolą ustawodawcy było szerokie zakreślenie odpowiedzialności sprawcy czynu; w innym przypadku określiłby w treści przepisu, że rozpowszechnienie musi nastąpić np. publicznie ${ }^{22}$. Rozpatrując kwestię rozpowszechniania, należy mieć na uwadze fakt, że obecnie najczęściej dzieje się to za pomocą mediów elektronicznych, jednak jak podkreślił Sąd Najwyższy w wyroku z dnia 13 kwietnia 2016 r. nie może to stanowić przesłanki obniżenia stopnia społecznej szkodliwości czynu ${ }^{23}$.

Powracając do kwestii braku zgody pokrzywdzonego na rozpowszechnianie jego nagiego wizerunku, należy wskazać, że w przypadku osób małoletnich pozostających pod władzą rodzicielską osobą władna do wyrażenia zgody w imieniu dziecka jest rodzic. W praktyce zgoda taka może być wyrażona przez jednego z rodziców, np. w przypadku zgody na utrwalanie i rozpowszechnianie wizerunku dziecka uwiecznionego przy okazji akademii bądź innych wydarzeń szkolnych. Istotne jest, że w przypadku wyrażenia zgody przez jedno z rodziców, drugie może sprzeciwić się czynności publikacji wizerunku małoletniego, tym samym stanowi to zabezpieczenie współdecydowania o kwestiach dotyczących dziecka. Zatem odpowiedzialność z tytułu wypełnienia znamion art. 191a k.k. nie

${ }^{18}$ R. Krajewski: Przestępstwo utrwalania i rozpowszechniania wizerunku nagiej osoby lub osoby w trakcie czynności seksualnej. „Prokuratura i Prawo” 2012, nr 5, s. 26.

${ }_{19}$ M. Mozgawa: Komentarz aktualizowany do art. 191(a) Kodeksu karnego...

${ }^{20}$ R. Krajewski: Przestęstwo utrwalania..., s. 28.

${ }^{21}$ M. Mozgaw a: Komentarz aktualizowany do art. 202 Kodeksu karnego. W: Kodeks karny. Komentarz aktualizowany. Red. M. Mozgawa. Warszawa 2017. LEX nr 534494.

${ }^{22}$ R. Krajewski: Przestępstwo utrwalania..., s. 28.

${ }^{23}$ Wyrok Sądu Najwyższego z dnia 13 kwietnia 2016 r., II KK 304/15. LEX nr 2019608. 
jest automatycznie wyłączona przez domniemanie, że publikując wizerunek małoletniego, rodzic wyraża w imieniu dziecka zgodę na upowszechnienie jego wizerunku. Po pierwsze, drugi z rodziców może się sprzeciwić takiej publikacji, a po drugie, mając na uwadze zasady współżycia społecznego oraz samą treść publikacji, a także wiek dziecka, każdy może zgłosić możliwość popełnienia przestępstwa z art. 191a k.k. organom ścigania, które winny wdrożyć odpowiedni tryb postępowania, mając oczywiście na względzie specyfikę trybu ścigania analizowanego przepisu, o czym w dalszej części artykułu.

Przestępstwo rozpowszechniania wizerunku osoby nagiej jest przestępstwem o charakterze umyślnym i może być popełnione $\mathrm{w}$ zamiarze bezpośrednim lub też ewentualnym ${ }^{24}$, co oznacza, że sprawca działa z zamiarem osiągnięcia określonego skutku, danego celu i ma zamiar popełnić określony czyn lub godzi się na jego popełnienie.

Analizowany czyn jest przestępstwem ściganym na wniosek. Oznacza to, że do wszczęcia postępowania niezbędne jest złożenie przez pokrzywdzonego wniosku o jego podjęcie i ściganie sprawcy czynu. W przypadku gdy pokrzywdzonym jest małoletni, uprawnionym do złożenia $\mathrm{w}$ jego imieniu wniosku o ściganie jest jego przedstawiciel ustawowy ${ }^{25}$. O reprezentowaniu małoletniego przez jedno z rodziców w postępowaniu karnym toczącym się przeciwko drugiemu z rodziców mowa będzie $\mathrm{w}$ dalszej części niniejszego artykułu.

\section{Znieważenie}

Poszukując dalszych uregulowań przepisów prawnokarnych, na podstawie których możliwe byłoby pociągnięcie do odpowiedzialności rodzica-trolla, warto zwrócić uwagę na art. 216 k.k., który stanowi o znieważeniu. W celu rozważenia, czy czyn określany mianem parental trollingu może wypełniać znamiona czynu znieważenia, niezbędna staje się analiza powołanego przepisu i przesłanek koniecznych takiego czynu.

Znieważenie niejednokrotnie mylone jest $\mathrm{z}$ pomówieniem czy zniesławieniem. Choć pojęcia te sa z pozoru bliskoznaczne, na gruncie Kodeksu karnego podlegaja istotnym różnicom. Poczynając od krótkiej charakterystyki znieważenia, należy podkreślić, że może ono dotyczyć wyłącznie osoby fizycznej, gdy tymczasem zniesławienie może odnosić się do każde-

24 J. Lachowski: Komentarz do art. 191(a) Kodeksu karnego...

${ }_{25}$ T. Bojarski: Komentarz do art. 191(a) Kodeksu karnego... 
go podmiotu ochrony prawnej ${ }^{26}$. W dalszej kolejności zniewaga polega na obraźliwym zachowaniu i nie wiąże się z formułowaniem zarzutu w formie pisemnej lub ustnej, jak ma to miejsce w przypadku pomówienia. Nadto znieważenie może nastąić przez każde zachowanie, nie musi to być określona forma zachowania, jak w przypadku zniesławienia.

Przedmiotem ochrony prawnokarnej w przypadku zniewagi pozostaje godność osoby fizycznej, zatem ochrona ta nie może być ograniczona ze względu na inne czynniki, jak: wiek, płeć, rasa, wyznanie itp. ${ }^{27}$ Godność, zgodnie z Konstytucją RP, jest przymiotem niezbywalnym i przyrodzonym, stanowiącym źródło wolności i praw człowieka i obywatela, nadto stanowi dobro nienaruszalne i podlegajace ochronie władz publicznych ${ }^{28}$. Omawiany przepis mówi o naruszeniu wewnętrznej czci osoby fizycznej29, która jest „immanentnie wpisana w godność”30. Należy dodać, że w przypadku niniejszego przepisu brak jest jakichkolwiek podstaw do ograniczenia wieku pokrzywdzonego, którego niektórzy doszukują się w wykładni analizowanego wyżej art. 191a k.k. W doktrynie pojawiaja się głosy wskazujące na daleko idaccą ochronę gwarantowana przez art. 216 k.k., a mianowicie, że ochronie takiej podlega także $n a$ sciturus $^{31}$. Autorzy takiego poglądu zwracają uwagę na kilka okoliczności uzasadniajacych przyjęcie ochrony dziecka nienarodzonego na podstawie cytowanego przepisu, mianowicie: Kodeks karny (art. 157a §1) przewiduje odpowiedzialność za uszkodzenie ciała lub rozstrój zdrowia dziecka poczętego, a nienarodzonego; nie ma wattpliwości, że pokrzywdzonym w przypadku pomówienia (art. 212) może być małoletni, a także że „dziecko poczęte ma prawo do zachowania integralności fizycznej i psychicznej i z tego względu przysługuje mu ochrona z zakresu dóbr osobistych z art. 23 i art. 24 k.c." 32 Nadto ci sami autorzy wskazują, że jeśli Kodeks karny gwarantuje ochronę czci jednostek organizacyjnych,

${ }^{26}$ D. Gil: Postępowanie $w$ sprawach $z$ oskarżenia prywatnego $w$ polskim procesie karnym. Warszawa 2011. LEX nr 132695.

${ }^{27}$ K. Dudka, M. Mozgawa: Zniewaga. W: Stosowanie prawa. Księga jubileuszowa z okazji XX-lecia Instytutu Wymiaru Sprawiedliwości. Red. A. Siemaszko. Warszawa 2011. LEX nr 133007.

${ }_{28}$ Artykuł 30 Konstytucji RP z dnia 2 kwietnia 1997 r. Dz.U. 1997, poz. 78, nr 448 z późn. zm.

${ }^{29}$ R.A. Stefański: Znaczenie zniewagi $w$ doktrynie $i$ judykaturze. W: Przestępstwa przeciwko czci i nietykalności cielesnej. Red. M. Mozgawa. Warszawa 2013. LEX nr 173106.

${ }^{30}$ I. Zgoliński: Zniestawienie w polskim prawie karnym. Warszawa 2013. LEX nr 173033.

${ }^{31}$ P. Jóźwiak: Prawnokarna ochrona czci i godności osobistej nasciturusa. W: Gwarancje praw pokrzywdzonych $w$ postępowaniach szczególnych. Red. D. Gil. Warszawa 2012. LEX nr 146092.

${ }^{32}$ Ibidem. 
to bardzo krzywdzace byłoby przyjęcie, że ochrona taka nie należy się nasciturusowi, zwłaszcza że przemawia za tym zasada nasciturus pro iam nato habetur, quotiens de commodis eius agitur, co oznacza, że dziecko poczęte uważa się za już narodzone, jeśli chodzi o jego korzyści ${ }^{33}$. Zatem nie powinno budzić żadnych wątpliwości, że ochronie takiej tym bardziej podlegają małoletni bez ograniczeń wiekowych, czyli poczynając od momentu narodzenia.

Na gruncie przepisów Kodeksu karnego ochrona czci sprowadzana jest do pojęć dobrego imienia, dobrej sławy, godności osobistej. Na podstawie analizowanego przepisu wymienione terminy podlegaja ochronie nie tyle ze względu na subiektywne odczucia człowieka, ile z uwagi na doniosłość i uznanie potrzeby ich ochrony przez system prawny ${ }^{34}$, co gwarantuja także regulacje Konstytucji RP, która stanowi, że każdy ma prawo do ochrony prawnej życia prywatnego, rodzinnego, czci i dobrego imienia oraz do decydowania o swoim życiu osobistym ${ }^{35}$. Mając powyższe na uwadze, ważne są obiektywne kryteria oceny naruszenia tychże dóbr, nie jest zaś decydujace odczucie samego pokrzywdzonego, które z kolei jest istotne ze względu na tryb ścigania sprawcy czynu wypełniającego znamiona art. 216 k.k. ${ }^{36}$

W doktrynie dominuje pogląd, że przestępstwo zniewagi można popełnić jedynie przez działanie ${ }^{37}$, natomiast brak jest możliwości popełnienia czynu przez zaniechanie ${ }^{38}$. Podstawowa forma zniewagi obejmuje działanie $\mathrm{w}$ obecności znieważanego albo chociażby pod jego nieobecność, lecz publicznie lub w zamiarze, aby zniewaga do niego dotarła. $\mathrm{Na}$ potrzeby niniejszego opracowania wskazane jest ograniczenie się do działania publicznego, przy jednoczesnym założeniu, że rodzic nie działa w zamiarze bezpośrednim znieważenia swojego dziecka. Pod pojęciem „działanie publiczne” rozumiemy każde działanie (w tym przypadku publikowanie treści za pośrednictwem sieci), z którym może zapoznać się bliżej nieograniczona grupa odbiorców. W przedmiocie parental trollingu także forma kwalifikowana w postaci znieważenia za pomoca środków

${ }^{33}$ Ibidem.

34 J. Sadomski: Cześć jako przedmiot ochrony w prawie cywilnym i karnym. W: Stosowanie prawa. Księga jubileuszowa z okazji XX-lecia Instytutu Wymiaru Sprawiedliwości. Red. A. Siemaszko...

${ }_{35}$ Artykuł 47 Konstytucji RP z dnia 2 kwietnia 1997 r. Dz.U. 1997, poz. 78, nr 448 z późn zm.

${ }^{36}$ M. Sosnowska: Relacje pomiędzy przestępstwem zniestawienia a przestępstwem zniewagi - zagadnienia wybrane. LEX nr 121145/1.

${ }^{37}$ K. Dudka, M. Mozgawa: Zniewaga...

${ }^{38}$ I. Zgoliński: Komentarz do art. 216 Kodeksu karnego. W: Kodeks karny. Komentarz. Red. V. Konarska-Wrzosek... 
masowego komunikowania może znaleźć zastosowanie ${ }^{39}$. Kwestią wymagająca wyjaśnienia jest to, czy Internet można kwalifikować jako środek masowego komunikowania ${ }^{40}$. Ze względu na brak ustawowego zdefiniowania takich środków, a także z uwagi na rosnące znaczenie komunikacji międzyludzkiej za pośrednictwem sieci zasadne wydaje się uznanie Internetu za taki właśnie środek.

Wracając jednak do meritum. W literaturze wskazuje się, że każde zachowanie uwłaczające godności pokrzywdzonego, które ma na celu wyszydzanie, lekceważenie, pogardliwe lub poniżające działanie może być kwalifikowane jako znieważanie ${ }^{41}$. $\mathrm{O}$ znieważajacym charakterze zachowania decyduje system ocen funkcjonujacy $\mathrm{w}$ danym społeczeństwie ${ }^{42}$. Jeśli jakieś zachowanie jest dopuszczalne i akceptowalne w określonym społeczeństwie, to mimo wypełnienia powyższych znamion może nie zostać uznane za znieważajace - oczywiście ostatecznej oceny w przypadku postępowania karnego dokonuja stosowne organy, mając także na uwadze zachowania dopuszczalne i akceptowane w danej społeczności, zasady współżycia społecznego i konkretne okoliczności sprawy. Jak wskazał Sąd Najwyższy w uchwale z dnia 5 czerwca 2012 r., „O tym, czy zachowanie miało charakter znieważający, decyduja dominujące $\mathrm{w}$ społeczeństwie oceny i normy obyczajowe, a nie subiektywne przekonanie osoby rzekomo znieważonej" ${ }^{33}$. Czyn znieważający może być dokonany „słowem, pismem, drukiem, wizerunkiem, a nawet gestem” ${ }^{44}$.

Jak już wspomniano, subiektywne odczucia pokrzywdzonego nie maja wpływu na ocenę określonego zachowania, ale pozostają istotne w zakresie ewentualnego pociagnięcia do odpowiedzialności sprawcy zniewagi ze względu na tryb ścigania przestępstwa zniewagi ${ }^{45}$.

Znieważanie jako jedno $\mathrm{z}$ niewielu przestępstw ścigane jest $\mathrm{w}$ trybie oskarżenia prywatnego, które polega na osobistym wystąpieniu pokrzywdzonego z prywatnym aktem oskarżenia przeciwko sprawcy czynu.

${ }^{39}$ Artykuł $216 \S 2$ ustawy z dnia 6 czerwca 1997 r. - Kodeks karny. Dz.U. 1997, nr 88, poz. 553 z późn. zm.

${ }_{40}$ M. Sowa: Ogólna charakterystyka przestępczości internetowej. „Palestra” 2001, nr 5-6, s. 28-3.

${ }^{41}$ R.A. Stefański: Znaczenie zniewagi $w$ doktrynie i judykaturze...

${ }^{42}$ Ibidem.

${ }^{43}$ Uchwała Sądu Najwyższego z dnia 5 czerwca 2012 r. SNO 26/12. LEX nr 1231618.

${ }_{44}$ M. Mozgawa: Komentarz aktualizowany do art. 216 Kodeksu karnego. W: Kodeks karny. Komentarz aktualizowany. Red. M. Mozgawa...

${ }^{45}$ R.A. Stefański: Znaczenie zniewagi $w$ doktrynie $i$ judykaturze... 


\section{Tryby ścigania a reprezentacja małoletniego przez przedstawiciela ustawowego}

W przypadku dwóch omówionych wcześniej przepisów Kodeksu karnego mamy do czynienia z dwoma zgoła odmiennymi trybami ścigania. W przypadku przestępstwa penalizowanego art. 191a k.k., jak już wspomniano, jest to tryb wnioskowy - aby wszcząć postępowanie skutkujące ściganiem sprawcy takiego przestępstwa, niezbędny jest wniosek samego pokrzywdzonego, natomiast w przypadku sprawcy przestępstwa znieważenia niezbędne jest złożenie prywatnego aktu oskarżenia.

W przypadku gdy pokrzywdzonym jest małoletni, osobą uprawniona do działania w jego imieniu jest przedstawiciel ustawowy, którym najczęściej pozostaja rodzice. Czy w przypadku gdy sprawca przestępstwa jest jedno z rodziców uprawnionym dalej pozostaje drugi rodzic? Nic bardziej mylnego. Sąd Najwyższy w składzie siedmiu sędziów w orzeczeniu w sprawie o sygn. akt I KZP 10/10 stwierdził, że „rodzic małoletniego pokrzywdzonego nie może, działajac w charakterze przedstawiciela ustawowego, wykonywać praw tego małoletniego jako pokrzywdzonego w postępowaniu karnym, w tym także w postępowaniu z oskarżenia prywatnego, jeżeli oskarżonym jest drugi z rodziców"46. Przemawia za tym przede wszystkim specyfika relacji rodzinnych łaczaccych pokrzywdzonego i jego rodziców, gdyż jeden z rodziców pozostaje w wewnętrznym konflikcie pomiędzy dobrem dziecka i faktem jego pokrzywdzenia a lojalnością względem rodzica sprawcy, przyjmujac, że rodzice dziecka pozostają w związku bądź w relacjach nieskonfliktowanych, gdyż cytując uzasadnienie powołanej uchwały w podobnej sytuacji „należy mieć na względzie, iż w wypadku gdy jeden z rodziców dziecka występuje de facto jako przeciwnik procesowy drugiego rodzica, zachodzić musi uzasadniona obawa związana z trudnością dokonania przez niego obiektywnej oceny sytuacji, mającej przede wszystkim na względzie interes dziecka, a nie swój własny". Sąd Najwyższy w przytoczonym orzeczeniu uznał, że ze względu na brak stosownych uregulowań w przepisach karnych zastosowanie winny mieć odpowiednie przepisy Kodeksu rodzinnego i opiekuńczego, „zgodnie [bowiem] z art. 98 \$ 2 pkt 2 k.r.o., żadne z rodziców nie może reprezentować dziecka przy czynnościach prawnych między dzieckiem a jednym z rodziców lub jego małżonkiem, chyba że czynność prawna polega na bezpłatnym przysporzeniu na rzecz dziecka, albo że

${ }^{46}$ Uchwała Sądu Najwyższego z dnia 30 września 2010 r., I KZP 10/10. LEX nr 602769. 
dotyczy należnych dziecku od drugiego z rodziców środków utrzymania i wychowania. Zgodnie zaś z kolejna jednostka redakcyjną art. 98 k.r.o., to jest z $\S 3$, przepisy paragrafu poprzedzającego stosuje się odpowiednio w postępowaniu przed sądem lub innym organem państwowym". W konsekwencji wskazane jest przyjęcie, że przytaczane przepisy Kodeksu rodzinnego i opiekuńczego maja zastosowanie także do postępowania karnego. Podsumowując, w przypadku gdy pokrzywdzonym jest małoletni, a prawdopodobnym sprawca czynu niedozwolonego rodzic, dziecko w postępowaniu karnym winno być reprezentowane przez kuratora ustanowionego przez są opiekuńczy. Zastosowania takiego rozwiązania w postępowaniu karnym wymaga nie tylko dobro samego pokrzywdzonego, lecz także dobro rodziny i potrzeba zapobieżenia możliwości jej rozkładu.

Należy dodać, że w przypadku postępowań inicjowanych prywatnym aktem oskarżenia również prokurator ma możność wystąić z takim aktem, gdy wymaga tego interes społeczny ${ }^{47}$. Ponadto istotne prawo przysługuje Rzecznikowi Praw Dziecka, który na podstawie art. 10 ust. 4 ustawy o Rzeczniku Praw Dziecka ${ }^{48}$ może żądać wszczęcia przez uprawnionego oskarżyciela postępowania przygotowawczego w sprawach o przestępstwa. Zatem każdy może zwrócić się do stosownych organów, zawiadamiając je o przypuszczeniu popełnienia przestępstwa. Organy te, mając możliwość działania z urzędu, w przypadku gdy pokrzywdzonym jest małoletni, a prawdopodobnym sprawca rodzic, winny w pierwszej kolejności skierować wniosek do sądu opiekuńczego o ustanowienie dla pokrzywdzonego kuratora, ten zaś występując w imieniu dziecka może złożyć stosowny wniosek o ściganie lub wystąpić z prywatnym aktem oskarżenia, gwarantując tym samym należytą ochronę małoletniemu.

\section{Podsumowanie}

Niewątpliwie na podstawie obowiązujących przepisów polskiego prawa karnego można pociagnąć rodzica do odpowiedzialności za czyny kwalifikowane jako parental trolling, jednak majac na uwadze stosunkowo szybki rozwój społeczeństwa i wirtualizację życia oraz powszechność udostępniania treści ośmieszających zawierających wizerunek dzieci,

${ }_{47}$ Artykuł 60 § 1 ustawy z dnia 6 czerwca 1997 r. — Kodeks postępowania karnego. Dz.U. 1997, nr 89, poz. 555 z późn. zm.

48 Artykuł 10 ust. 4 ustawy o Rzeczniku Praw Dziecka. Dz.U. 2000, nr 6, poz. 69 z późn. zm. 
obecny charakter ochrony prawnokarnej jest znikomy i niewystarczajacy. Konieczność poszukiwania i dopasowania przesłanek wypełniających znamiona parental trollingu wśród przesłanek czynów zabronionych występujących w polskim Kodeksie karnym jedynie w celu pociągnięcia do odpowiedzialności rodzica stosującego wobec własnego dziecka swoista cyberprzemoc pozostaje istotna luką w ochronie praw dziecka. Oczywiście, w postępowaniach przeciwko rodzicom należy zachować rozwagę, możemy bowiem doprowadzić do skrajnych przypadków, gdy trzymanie zdjęć własnego dziecka $\mathrm{w}$ albumie rodzinnym i okazjonalne ich pokazywanie znajomym i rodzinie wypełniać będzie znamiona przestępstwa, niemniej jednak dobro dziecka jest wartościa nadrzędna, która wymaga szczególnej ochrony. Dlatego też mając na uwadze szybki rozwój społeczeństwa, w tym przede wszystkim kierunek rozwoju komunikacji międzyludzkiej $\mathrm{w}$ dobie powszechnego dostępu do sieci, istotne pozostaje podjęcie działań zmierzających do zapewnienia ochrony praw i wizerunku dziecka w aspekcie coraz powszechniejszych działań wypełniających znamiona parental trollingu. Słusznie zauważa C. Nowak, że „procesy globalizacyjne wiążą się z postępem w zakresie technologii, zwłaszcza komunikacyjnych. Ustawodawca stara się nadążyć za przemianami technologicznymi i kryminalizować niepożądane społecznie zachowania podejmowane przy użyciu nowoczesnych urządzeń i technologii. Modernizacja technologiczna implikuje zatem modernizację unormowań prawnokarnych" ${ }^{\prime 9}$. Taka modernizacja powinna nastąić również w aspekcie szerzącego się parental trollingu.

${ }^{49}$ C. Nowak: Wptyw procesów globalizacyjnych na polskie prawo karne. Warszawa 2014. LEX nr 213751. 


\title{
Karolina Rybak*
}

\section{Rodzina trolli — porównanie konstrukcji copyright i patent trollingu}

\begin{abstract}
The aim of this article is to to compare the two constructions of copyright and patent trolling. Prima facie it may seem that both these phenomena are based on the very same basic - which is to claim the damages for the infringement of copyrights or patents. However, while analysing these constructions, it is possible to perceive both similarities and differences. At first, it is necessary to define notions of copyright and patent trolling and to analyze mode of action of both kinds of trolls. In this article, the author tries to answer the question, if it is possible to view every activity falling within the framework of the definition of trolling as an abuse of economic rights of copyright or patents. Afterwards, senders of demands of payment shall be characterized as well as the existence of the infringement by addressee's behaviors. What is more, it is necessary to bring the role of law offices out. Finally, main difference between analyzed constructions will be indicated, revolving around the feeling of threat based not only on the economic foundation.
\end{abstract}

Keywords: patent, copyright, trolling, comparision

\section{Wstęp}

W wyemitowanym po raz pierwszy w 1994 r. filmie edukacyjnym pt. The Patent's video, autorstwa prawniczki Pauli Natashy Chavez ${ }^{1}$,

* Mgr, Uniwersytet Ślasski w Katowicach.

${ }^{1}$ P.N. Chavez: The Original Patent Troll, https://www.youtube.com/watch?v=lOGoZFzHkhs [Data dostępu: 28 stycznia 2018 r.]. 
patent ukazano za pomoca niezwykle ciekawej metafory. Mianowicie przyjęto, że drogę do pozyskania uprawnienia do korzystania z patentu można utożsamić z granica. Potencjalny użytkownik znajduje się po jednej stronie granicy, natomiast uprawnienie do skorzystania z patentu znajduje się po jej drugiej stronie. Użytkownik, chcac skorzystać z patentu, powinien uzyskać zgodę uprawnionego z patentu, czyli przejść przez łączący granice/brzegi most. Jednakże, niczym w norweskich baśniach, pod owym mostem jednak kryje się czyhający na przechodnia złowieszczy troll. Troll nie jest zainteresowany budową mostów ani ich utrzymaniem. Schowany w cieniu, chce tylko dopaść kolejnej ofiary — zbierać „opłaty” za przekroczenie mostu od tych, którzy muszą przez niego przejśśc ${ }^{2}$.

Współcześnie nie musimy szukać trolli, które znacznie ewoluowały, w jaskiniach, lasach czy pod mostami. Skrywaja się one w czeluściach Internetu, a poszukiwanie przez nich ofiar stało się o wiele prostsze.

Celem niniejszego artykułu jest analiza dwóch spokrewnionych $\mathrm{z}$ sobą typów trollingu, tzn. trollingu prawnoautorskiego i trollingu patentowego. Błędna jest bowiem hipoteza zakładająca tożsamość obu tych konstrukcji. Mimo że zostały oparte na tej samej zasadzie dochodzenia odszkodowania za dokonanie rzekomych naruszeń, odpowiednio majątkowych praw autorskich i patentu, znaczne różnice występują w zakresie ich swoistego modus operandi. Należy zaznaczyć, że omawiane cechy abstrahować będą od różnic wynikających z konstrukcyjnych założeń prawa autorskiego i prawa własności przemysłowej, takich jak obowiązek wypełnienia wymogów formalnych czy czas trwania ochrony. Jednocześnie, mimo oparcia artykułu na literaturze w znacznej mierze amerykańskiej, pominięte zostaną aspekty trollingu typowe dla specyfiki amerykańskich trolli, jak masowe łączenie postępowań sądowych, które uważane jest za jedna z głównych przyczyn rozwoju tego zjawiska. Dążąc jednak do kompleksowego przedstawienia problematyki trollingu w prawie własności intelektualnej, opracowanie częściowo będzie miało charakter porównawczy.

W pierwszej kolejności konieczne jest zdefiniowanie pojęć „patent” i „copyright trolling”. Uzupełnienie rozważań na ten temat będzie stanowiło scharakteryzowanie sposobu działania trolli obu rodzajów. Następnie dokonana zostanie kwalifikacja działań trolli i podjęta próba odpowiedzi na pytanie, czy każdorazowo można uznać działania wpisujące się w ramy definicji trollingu za nadużycie praw przysługujących uprawnionym z tytułu majątkowych praw autorskich i patentu. W dalszej kolejności scharakteryzowani zostaną nadawcy wezwań do zapłaty oraz oko-

${ }^{2}$ I. Polonsky: You Can't Go Home Again: The Righthaven Cases and Copyright Trolling on the Internet. „Columbia Journal of Law \& the Arts” 2012, vol. 36, s. 72. 
liczność istnienia naruszenia przez adresatów tych wezwań. Omawiając trolling, nie sposób pominać uczestnictwa kancelarii prawnych w tym procederze. Na koniec wskazana zostanie podstawowa różnica pomiędzy analizowanymi konstrukcjami, polegająca na korzystaniu z innych przesłanek w celu zastraszenia adresatów wezwań.

\section{Patent trolling}

Pojęcie patent trolling zostało użyte po raz pierwszy we wspomnianym wcześniej filmie edukacyjnym, jednak dopiero gdy w 2001 r. posłużył się nim prawnik przedsiębiorstwa Intel P. Detkin, zostało ono wprowadzone na stałe do języka powszechnego ${ }^{3}$. Zdaniem P. Detkina, trollami sa przedsiębiorstwa, które staraja się zarobić dużą ilość pieniędzy z patentu, którego nie używają i nie maja zamiaru używać, a z którego w większości przypadków nawet nie skorzystano ${ }^{4}$.

Próba zdefiniowania trollingu patentowego nie jest zadaniem łatwym. Co do zasady sprowadza się ona do wskazania cech, jakimi charakteryzuje się działalność większości trolli. I tak troll patentowy może zostać zdefiniowany jako „podmiot, któremu wprawdzie przysługuje prawo wyłączne (często o wątpliwych podstawach), jednak zostało ono przez niego uzyskane przede wszystkim w celu blokowania konkurencji i dochodzenia roszczeń czy wymuszania ugód"5.

Często ${ }^{6}$ powoływaną w amerykańskiej doktrynie definicja patent trollingu jest ta sformułowana w postępowaniu eBay Inc. przeciwko MercExchange, L.L.C. przez sędziego A. Kennedy'ego. Sędzia stwierdził, że jest to rodzaj branży, w której przedsiębiorstwa korzystaja z patentów nie dla podstawy produkowania i sprzedawania dóbr, ale przede wszyst-

${ }^{3}$ B.L. Frye: IP as Metaphor. „Chapman Law Review” 2015, no. 18, s. 745; J. Johnson, G.K. Leonard, Ch. Meyer, K. Serwin: Don't feed the trolls? „Les Nouvelles” 2007, s. 487.

${ }^{4}$ J. Johnson, G.K. Leonard, Ch. Meyer, K. Serwin: Don't feed..., s. 487.

${ }_{5}^{5}$ M. Kubiak: Komentarz do art. 285 prawo własności przemystowej. W: Prawo własności przemysłowej. Komentarz. Red. A. Michalak. Warszawa 2016. LEGALIS, nb 7.

${ }^{6}$ Por.: J. Johnson, G.K. Leonard, Ch. Meyer, K. Serwin: Don't feed..., s. 48; A. Mayergoyz: Lessons from Europe on how to tame U.S. patent trolls. „Cornell International Law Journal" 2009, no. 42, s. 254; M. Fawcett, J. Chan: March of the trolls: footsteps getting louder. „Intellectual Property Law Bulletin” 2008, no. 13, s. 12; M.A. Lemley, D. Melamed: Missing the forest for the trolls. „Columbia Law Review” 2013, no. 113, s. 2174; E. Lee: Patent trolls: moral panics, motion in limine, and patent reform. „Stanford Technology Law Review” 2015, no. 19, s. 123. 
kim dla uzyskiwania opłat licencyjnych. Dla przedsiębiorstw tego typu uwzględnienie przez sąd roszczenia o zaniechanie naruszeń oraz potencjalnie poważne sankcje wynikające $\mathrm{z}$ tego naruszenia stanowią narzędzie negocjacyjne, służące do obciążenia nadmiernie wygórowanymi opłatami przedsiębiorstw chcących uzyskać licencję na korzystanie z danego patentu?

Próbę zdefiniowania trolli patentowych podjęła również Subcommittee on Courts, the Internet, and Intellectual Property of the Committee on the Judiciary House of Representatives. Jej członkowie stwierdzili, że stworzenie takiej definicji nie jest możliwe ze względu na to, że tego typu zachowanie przybiera różne formy. Ograniczeniem dla trolli jest jedynie ludzka kreatywność. Uznano zatem, że niezbędne jest skupienie się wyłącznie na cechach, które nie są pożądane w żadnym przypadku. Majac to na uwadze, wyodrębniono następujace cechy „czystego trollingu”:

- nieposiadanie znaczacego kapitału poza patentami;

- nieprodukowanie towarów na podstawie patentu;

- szczególna rola prawników w działalności trolla;

- brak korzystania z nabytych patentów w ramach twórczości wynalazczej ${ }^{8}$.

Do biernego korzystania z patentów odniósł się także najsłynniejszy amerykański „łowca trolli” Barack Obama. W lutym 2013 r. w swoim przemówieniu wskazał on, że „działalność trolli nie polega na produkowaniu przez nich samych. Ich jedynym celem jest wykorzystanie i przejęcie kontroli nad pomysłem innego podmiotu i sprawdzenie, czy moga zarobić na tym jakieś pieniądze"9.

W pracach poświęconych omawianemu zagadnieniu, które ukazały się w amerykańskich czasopismach naukowych, wskazuje się, że trolle patentowe swoim postępowaniem moga wiele zyskać. Pod ich wpływem bowiem przedsiębiorstwa zawierają ugody, aby uniknać poniesienia znacznych kosztów sądowych i żądania zakazania naruszeń ${ }^{10}$. Zakazanie dalszego dokonywania naruszeń jest szczególnie istotne dla „naruszyciela”. Przykład może tu stanowić sytuacja, w której przedsiębiorstwo produkuje urządzenia elektroniczne, jak np.: telefony komórkowe, tablety, od-

${ }^{7}$ A. Kennedy: eBay INC. v. MercExchange, L.L.C. on writ of certiorari to the United States Court of Appeals for the Federal Circuit, 2006.

${ }^{8}$ Patent trolls: fact or fiction? Hearing before the Subcommittee on Courts, the Internet, and Intellectual Property of the Committee on the Judiciary House of Representatives. 109th Congress, 2nd Session, 2006. Serial No. 109-104, http://commdocs.house. gov/committees/judiciary/hju28201.000/hju28201_0f.htm [Data dostępu: 28 stycznia 2018 r.].

${ }^{9}$ President Obama Participates in a Fireside Hangout on Google+, https://www. youtube.com/watch?v=kp_zigxMS-Y [Data dostępu: 28 stycznia 2018 r.].

${ }^{10}$ A. Mayergoyz: Lessons from Europe..., s. 242-243. 
twarzacze mp3. Tego typu urządzenia składają się z licznych elementów. Brak możliwości skorzystania z jakiegoś wynalazku, stanowiącego jedynie mała, w oderwaniu od całości nic nieznaczącą część urządzenia, rodzi albo przymus przystania na warunki stawiane przez trolla, albo potrzebę znalezienia zamiennika, co może się wiąać z koniecznością przeprojektowania danego urządzenia tak, by było ono kompatybilne z zamienioną częścią. Problem ten został zauważony również w polskiej literaturze w kontekście roszczenia o zaprzestanie działań grożących naruszeniem prawa ${ }^{11}$. Wskazuje się na konieczność zachowania przez sąd dużej ostrożności podczas oceny zasadności wskazanego roszczenia, jego uwzględnienie bowiem oznacza konieczność zaprzestania przez pozwanego działań, które nie stanowią jeszcze naruszenia ${ }^{12}$. Należy zasygnalizować, że jedna z cech charakterystycznych dla polskich trolli jest to, że w większości nie wnoszą w stosunku do rzekomych naruszycieli powództw, a jedynie poprzestają na przedsądowych wezwaniach do zapłaty. Z tego też względu rozważania nad procesowymi aspektami działalności trolli maja jedynie marginalne znaczenie.

Zważywszy, że trolle patentowe w większości działają w granicach swoich uprawnień wynikających z posiadania patentu, zakwalifikowanie działalności danego podmiotu jako trolla ciągle przysparza trudności. Za kwintesencję działalności trolla uznaje się przykładanie większej wagi do kwestii związanych z uzyskiwaniem kwot oznaczanych w wezwaniach do zawarcia ugód niż do produkowania, sprzedawania towarów stworzonych na podstawie patentu lub jego licencjonowania ${ }^{13}$.

Oparcie się jedynie na wyżej wskazanym kryterium prowadzić może do błędnych wniosków. Zgodnie z przytoczonym kryterium, można byłoby się zastanawiać, czy trollem nie będzie uniwersytet, który nie czyni użytku z posiadanego patentu. Podobnie rzecz się ma w sytuacji, gdy wynalazca jest osoba niewspółpracujacca z większym podmiotem, która chce udzielić licencji dużemu przedsiębiorstwu. Potencjalnemu kontrahentowi takie zachowanie może kojarzyć się z trollingiem. Nie sposób jednak uznać, że wskazane podmioty można zaliczyć do kategorii trollów ${ }^{14}$.

${ }_{11}$ Artykuł 285 ustawy z dnia 30 czerwca 2000 r. — Prawo własności przemysłowej. Tekst jedn. Dz.U. 2017, poz. 776.

${ }_{12}$ M. Kubiak: Komentarz do art. 285...

${ }_{13}$ M. Sag: Copyright trolling, an empirical study. „Iowa Law Review” 2015, no. 100, s. 1108.

${ }^{14}$ J. Johnson, G.K. Leonard, Ch. Meyer, K. Serwin: Don't feed..., s. 487-488. 


\section{Copyright trolling}

Pojęcie „troll prawnoautorski” jest tak samo trudne do zdefiniowania, jak jego pierwowzór. Za trolla uznaje się podmiot, który chociaż sam może nie być twórca, jednak posiada legitymację czynna (lub pełnomocnictwo) do wnoszenia powództw przeciwko rzekomym naruszycielom, a następnie grozi wniesieniem takiego powództwa. Celem trolla prawnoautorskiego jest nakłonienie do zawarcia jak największej liczby ugód $\mathrm{z}$ anonimowymi podmiotami, natomiast jego intencja nie jest wszczynanie postępowania sądowego ${ }^{15}$.

Copyright trolling jest konstrukcją podobną do patent trollingu. Jego zamiarem jest wywołanie przekonania u adresata wezwania do zapłaty, że zawarcie ugody będzie dla niego rozwiązaniem korzystniejszym niż wdawanie się w spór sądowy ${ }^{16}$.

Zdaniem O. Wrzeszcz, trolling prawnoautorski można rozumieć jako „działania uprawnionych lub potencjalnie uprawnionych do dysponowania majątkowymi prawami autorskimi, polegajace na zastraszaniu, stosowaniu szantażu lub innych form nacisku, w celu uzyskania korzyśsi majątkowych z tytułu zawartej ugody od osoby potencjalnie dokonujacej naruszenia majątkowych praw autorskich w Internecie"17.

Wspomniana autorka opisała istotę zjawiska trollingu prawnoautorskiego, wskazując na następujące jego elementy:

- udział kancelarii prawnych lub firm okołoprawniczych;

- związek z rozpowszechnianiem utworów bez zgody twórcy w sieci P2P;

- naruszonym utworem sa zwykle filmy pornograficzne;

— naruszycieli identyfikuje się na podstawie ich adresów IP, ustalonych podczas wszczętego wobec nich postępowania karnego;

- masowe wysyłanie wezwań do zapłaty, często do przypadkowych osób;

- wywołanie u odbiorcy pisma poczucia zagrożenia;

— działanie nakierowane jest na uzyskanie korzyści majątkowej, a nie na ochronę przysługujących praw autorskich;

${ }^{15}$ L.S. Curran: Copyright trolls, defining the line between legal ransom letters and defending digital rights: turning piracy into a business model or protecting creative from internet lawlessness? „John Marshall Review of Intellectual Property Law” 2013, no. 13, s. 172; S. Balganesh: The uneasy case against copyrighttrolls. „Southern California Law Review" 2013, no. 83, s. 732; A. Ro sen: The Big Lawsuits Keep on Coming: An Analysis of Extortive Pornographic Trolling Lawsuits and Preventive Approaches. „Journal of the Patent and Trademark Office Society” 2013, no. 194, s. 169.

${ }^{16}$ M. Maj: „Copyright trolling” — raport, https://prawokultury.pl/media/entry/at tach/MMaj-CopyrightTrolling-raport.pdf [Data dostępu: 28 stycznia 2018 r.].

${ }^{17}$ O. Wrzeszcz: Trolling prawnoautorski (,copyright trolling”). „Zeszyty Naukowe Uniwersytetu Jagiellońskiego. Prace z Prawa Własności Intelektualnej” 2016, z. 134, s. 49. 
- brak zawarcia ugody rzadko skutkuje wszczęciem postępowania sądowego ${ }^{18}$.

Wskazane cechy stanowią dobrą podstawę analizy podobieństw i różnic między konstrukcjami trollingu patentowego a prawnoautorskiego.

\section{Charakterystyka postępowania}

W pierwszej kolejności należy skupić uwagę na samej idei, na jakiej oparte sa omawiane konstrukcje. Jak już wspomniano, oba zjawiska dotyczą zachowań podmiotów, które wykorzystują przysługujące im uprawnienia ochronne ich praw $\mathrm{z}$ zakresu własności intelektualnej $\mathrm{w}$ celu uzyskania opłaty licencyjnej lub odszkodowania za ich naruszenie, jednocześnie jednak nie wykazują zamiaru korzystania z praw autorskich lub z patentu w innym zakresie ${ }^{19}$.

Sposób działania trolla patentowego można określić w następujący sposób. Po pierwsze, troll poszukuje możliwości nabycia patentu po niskiej cenie. Niejednokrotnie odbywa się to podczas wyprzedawania majątku upadających przedsiębiorstw lub indywidualnych inwestorów, albo w ramach nabycia patentu od małych podmiotów, których nie stać na odpowiednią ochronę patentu ${ }^{20}$. Wybierając patenty, troll zwraca szczególną uwagę na te, które znajdują zastosowanie w dużej liczbie produktów, zwłaszcza jeżeli odgrywają kluczową rolę w funkcjonowaniu danego urządzenia. Zazwyczaj nabywane $\mathrm{w}$ ten sposób patenty sa dość stare, lecz nadal odgrywają znaczacą rolę w technologii ${ }^{21}$.

Posiadając ogół uprawnień związanych z danym patentem, troll poszukuje podmiotów, które albo nieuprawnione korzystają z niego, albo też na podstawie ich działalności można wywnioskować, że w przyszłości będą ubiegały się o zgodę na jego wykorzystanie w swojej działalności. Po odnalezieniu potencjalnych „ofiar” troll wysyła setki, a nawet tysiace listów oferujących zawarcie licencji na dany patent lub zawierających wezwanie do zawarcia ugody, grożąc wniesieniem powództwa w razie jej niezaakceptowania ${ }^{22}$.

\footnotetext{
${ }^{18}$ Ibidem, s. 45.

19 I. Polonsky: You Can't Go..., s. 75.

20 A. Mayergoyz: Lessons from Europe..., s. 242.

${ }^{21}$ Ibidem, s. 245-246.

22 P. Sánchez Abril, R. Plant: The Patent Holder's Dilemma: Buy, Sell, or Troll? „Communications of the Association for Computing Machinery” 2007, vol. 50, no. 1, s. 43.
} 
Podobny jest sposób działania trolla prawnoautorskiego. W pierwszej kolejności poszukuje on podmiotu uprawnionego z tytułu majątkowych praw autorskich, który chce wszczynać postępowania przeciwko rzekomym naruszycielom jego praw autorskich. Charakterystyczne dla tego typu działalności jest wybieranie utworów pornograficznych ${ }^{23}$. W Polsce wezwania do zapłaty dotyczą raczej filmów rodzimej produkcji. Ostatnim utworem, którego dotyczą tego typu pisma, jest film Wkręceni 2, w przypadku którego adresat listu jest wzywany do zapłaty kwoty 2500 zł tytułem „odszkodowania z tytułu bezprawnego udostępniania w Internecie utworu audiowizualnego pt. Whręceni 2".

Kolejny krok stanowi ustalenie rzekomych naruszycieli i skierowanie do nich wezwań. Podobnie jak w Stanach Zjednoczonych, trolle korzystaja w tym celu z usług przedsiębiorstw specjalizujących się w monitorowaniu i śledzeniu systemu pobierania $\mathrm{P}_{2} \mathrm{P}^{24}$. Tego typu działalność opiera się na modelu klient - klient, co oznacza, że każdy użytkownik jest zarówno serwerem przesyłajaccym dane niezbędne do pobrania utworu, jak i klientem ${ }^{25}$.

Zachowanie trolla można wpisać do następujacego scenariusza. W pierwszej kolejności trolle zlecają ustalenie adresów IP komputerów, z których miałoby dojść do nieuprawnionego rozpowszechnienia utworu. Następnie adresy te przekazywane są do kancelarii prawnych. Rola kancelarii jest złożenie zawiadomienia o podejrzeniu popełnienia przez „ustalone" w ten sposób osoby przestępstwa rozpowszechniania bez uprawnienia cudzego utworu ${ }^{26}$. W ramach postępowania organy ścigania ustalają dane osobowe podmiotów będących abonentami usługi dostępu do Internetu, za pomoca której miało dojść do rozpowszechnienia utworu. Uzyskane w ten sposób dane umieszczane są w aktach sprawy karnej i wykorzystane do przesłania rzekomemu naruszycielowi wezwania do zawarcia ugody ${ }^{27}$.

${ }^{23}$ G.S. Mortenson: BitTorrent Copyright Trolling: A Pragmatic Proposal for a Systemic Problem. „Seton Hall Law Review” 2013, no. 43, s. 1112.

${ }^{24}$ Ibidem.

25 O. Wrzeszcz: Trolling prawnoautorski..., s. 39.

${ }_{26}$ Artykuł 116 ustawy z dnia 4 lutego 1994 r. o prawie autorskim i prawach pokrewnych. Dz.U. 2017, poz. 880 z późn. zm.

${ }^{27}$ N. Mileszczyk: „Copyright trolling” — skala zjawiska i propozycje rozwiazań, https://centrumcyfrowe.pl/blog/2016/03/10/copyright-trolling-skala-zjawiska-i-propo zycje-rozwiazan/ [Data dostępu: 28 stycznia 2018 r.]. 


\section{Kwalifikacja działań}

Należy zwrócić uwagę, że działanie trolli, zarówno patentowych, jak i prawnoautorskich, prima facie stanowi jedynie ochronę przysługujacych im patentów i autorskich praw majątkowych. Uzyskanie patentu powoduje nabycie prawa wyłącznego do korzystania z wynalazku w sposób zarobkowy lub zawodowy na całym obszarze Rzeczypospolitej Polskiej ${ }^{28}$. W ramach patentu uprawniony do niego może zakazać osobie trzeciej, która nie uzyskała jego zgody, korzystania z wynalazku w sposób zarobkowy lub zawodowy, polegajacy na wytwarzaniu, używaniu, oferowaniu, wprowadzaniu do obrotu lub importowaniu dla tych celów produktu będącego przedmiotem wynalazku ${ }^{29}$.

Monopol, ograniczony jedynie innymi przepisami ustawy, a nadajacy twórcy wyłączne prawo do korzystania z utworu i rozporządzania nim na wszystkich polach eksploatacji, przewidziany jest również w prawie autorskim $^{30}$.

Dlaczego więc trolling uznawany jest za zjawisko naganne? Na tę ocenę składa się kilka czynników. Po pierwsze, poddawany krytyce jest nie sam fakt egzekwowania praw przysługujaccych jednostce, lecz sposób, $\mathrm{w}$ jaki realizowane sa jej uprawnienia ${ }^{31}$. W szczególności niedopuszczalne jest to, że w ramach działania trolla prawnoautorskiego niejednokrotnie wywołuje się obawę adresata wezwania związaną z upokorzeniem i wstydem, jakie mogłoby wywołać wszczęcie postępowania sądowego ${ }^{32}$. Najlepszym przykładem tego jest okoliczność, że pierwsze zachowania charakteryzowane jako copyright trolling dotyczyły pobierania z Internetu filmów pornograficznych.

Po drugie, niejednokrotnie to, czy w danym przypadku dokonane zostało naruszenie praw, jest wątpliwe. Tożsamość rzekomych naruszycieli ustala się na podstawie ich adresu IP. Nie sposób jednak zweryfikować, która z osób dokonała (jeśli dokonała) pobrania utworu z Internetu. Zamieszkiwanie $\mathrm{w}$ jednym gospodarstwie domowym wielu osób, które wspólnie korzystają z jednego komputera, praktycznie uniemożliwia wskazanie sprawcy.

${ }^{28}$ Artykuł 63 ustawy z dnia 30 czerwca 2000 r. — Prawo własności przemysłowej.

${ }^{29}$ Artykuł 66 ust. 1 pkt 1 ustawy z dnia 30 czerwca 2000 r. - Prawo własności przemysłowej.

${ }^{30}$ Artykuł 17 ustawy z dnia 4 lutego 1994 r. o prawie autorskim i prawach pokrewnych.

${ }^{31}$ O. Wrzeszcz: Trolling prawnoautorski..., s. 39.

32 A. Rosen: The Big Lawsuits Keep..., s. 171. 
Po trzecie, wysokość kwoty podanej na wezwaniu do zapłaty jest nieuzasadniona. Pismo wystosowane przez trolla nie precyzuje sposobu miarkowania wysokości proponowanej kwoty ugodowej czy też odszkodowania $^{33}$.

Zazwyczaj działania trolla oceniane sa jako nadużycie prawa podmiotowego. $Z$ jego perspektywy zakazane jest czynienie ze swego prawa użytku, który byłby sprzeczny ze społeczno-gospodarczym przeznaczeniem tego prawa lub z zasadami współżycia społecznego. Takie działanie lub zaniechanie uprawnionego nie jest uważane za wykonywanie prawa i nie korzysta $z$ ochrony ${ }^{34}$.

W ślad za M. Pyziak-Szafnicką uznać należy, że zachowanie sprzeczne z zasadami współżycia społecznego może mieć miejsce zarówno na etapie zgłoszenia żądania, jak i na wcześniejszym etapie przedsądowego zachowania $^{35}$. Jednakże uznanie działania trolla, zwłaszcza jeżeli jest on rzeczywiście podmiotem uprawnionym $\mathrm{z}$ tytułu majątkowych praw autorskich, za sprzeczne ze społeczno-gospodarczym przeznaczeniem prawa nie jest jednoznaczne. Słuszne wydaje się twierdzenie, że każdorazowe rozstrzygnięcie kwestii, czy dane postępowanie nie stanowi nadużycia prawa, będzie należało do sądu. Pamiętać bowiem należy, że celem wskazanych wyżej regulacji prawnych jest ochrona praw przysługujących uprawnionemu z patentu lub z majątkowych praw autorskich. Oznacza to, że prima facie nie sposób stwierdzić, że dochodzenie ochrony przez podmiot do tego uprawniony $\mathrm{w}$ zakresie przewidzianym $\mathrm{w}$ przepisach prawa stanowi działanie sprzeczne ze społeczno-gospodarczym przeznaczeniem przysługujących mu praw. Jednakże wattpliwe wydaje się, czy zachowanie takich podmiotów nakierowane jest rzeczywiście na ochronę ich uprawnień, czy też ich działania nie wypaczają sensu regulacji i pod pozorem egzekwowania przysługujaccych im praw nie jest prowadzona jedynie działalność biznesowa oparta na biernym korzystaniu ze wcześniej stworzonych wytworów ${ }^{36}$.

W polskiej literaturze znalazło się stanowisko wprost określające działalność trolli jako nadużywanie swoich praw wyłacznych ${ }^{37}$. Postulować należy jednak, aby kwestia, czy doszło do nadużycia prawa, była każdorazowo weryfikowana przez sąd.

${ }^{33}$ O. Wrzeszcz: Trolling prawnoautorski..., s. 43.

${ }_{34}$ Artykuł 5 ustawy z dnia 23 kwietnia 1964 r. — Kodeks cywilny. Tekst jedn. Dz.U. 2017, poz. 459 z późn. zm.

${ }^{35}$ M. Pyziak-Szafnicka: Komentarz do art. 5 Kodeksu cywilnego. W: Kodeks cywilny. Komentarz. Część ogólna. Red. P. Księżak. 2014. LEX.

${ }^{36}$ O. Wrzeszcz: Trolling prawnoautorski..., s. 56-57.

${ }^{37}$ M. Kubiak: Komentarz do art. 285... 


\section{Nadawcy wezwań do zapłaty}

W dalszej kolejności należy odnieść się do pomiotów kierujących wezwania do zapłaty. O ile bowiem w patent trollingu są to przedsiębiorstwa będace podmiotami uprawnionymi z tytułu patentu, o tyle w copyright trollingu grono trolli jest szersze. Poza podmiotami uprawnionymi z tytułu majątkowych praw autorskich, trollami sa również podmioty go pozbawione, a tym samym nieposiadające legitymacji do dochodzenia roszczeń za naruszenie majątkowych praw autorskich. Po raz kolejny odwołujacc się do O. Wrzeszcz, wskazać należy na okoliczność, że troll patentowy staje się uprawnionym z patentu na skutek wykorzystania niedoskonałości w regulacjach prawa patentowego, natomiast troll prawnoautorski wcale nie musi być uprawnionym do dochodzenia roszczeń z tytułu naruszenia majątkowych praw autorskich, co więcej wcale nie musi dojść do jakiegokolwiek naruszenia ${ }^{38}$. Wspomniana autorka wskazuje zatem na potrzebę dokonania rozróżnienia pomiędzy trollingiem pośrednim a bezpośrednim. Ten pierwszy ma miejsce, gdy podmiot uprawniony dochodzi roszczeń od naruszyciela majątkowych praw autorskich. Natomiast z trollingiem bezpośrednim mamy do czynienia, gdy co najmniej po jednej stronie brak legitymacji do wystapienia $\mathrm{w}$ procesie, tj. wtedy, gdy po stronie czynnej występował będzie podmiot nieposiadający majątkowych praw autorskich do utworu stanowiącego przedmiot sporu, albo też po stronie biernej będzie występował podmiot, który nie dokonał naruszenia ${ }^{39}$.

\section{Istnienie naruszenia}

Zarówno w przypadku trollingu patentowego, jak i trollingu prawnoautorskiego nie musimy mieć do czynienia z naruszeniem. Co więcej, niejednokrotnie podmiot, do którego trolle kierują wezwania do zapłaty, nie musi być naruszycielem. Jako przykład wskazać można pobieranie z Interentu plików za pomoca metody P2P. Na podstawie adresu Internet Protocol (IP) nie sposób określić, czy dana osoba w rzeczywistości dokonała naruszenia. Adres IP jest rozumiany jako zestaw standardów odpo-

\footnotetext{
${ }^{38}$ O. Wrzeszcz: Trolling prawnoautorski..., s. 49.

${ }^{39}$ Ibidem.
} 
wiedzialnych za zapewnienie, że dane transmitowane przez Internet sa skierowane do zamierzonych destynacji. Stanowi numeryczne przedstawienie urządzenia podłączonego do sieci, które przekazuje informacje, korzystajac z Internet Protocol. Jego celem jest anonimowe zlokalizowanie urządzenia podłączonego do sieci. Od decyzji użytkowników zależy, czy pozostaną anonimowymi, czy też dobrowolnie ujawnią identyfikujące informacje $\mathrm{e}^{40}$.

Jak już wspomniano, adres IP wskazuje jedynie na łącze internetowe, nie można na jego podstawie ustalić osoby, która naruszyła prawa autorskie. Ponadto nie można takiej osoby utożsamiać z abonentem danego łacza ${ }^{41}$.

Podobnie jest w przypadku trolli patentowych. Ich celem jest ściganie nie przedsiębiorstw rzeczywiście korzystających z naruszanego patentu, ale odbiorców końcowych takich, jak mali przedsiębiorcy, organizacje czy indywidualne jednostki. Przykładem moga być trolle patentowe, które rozesłały tysiące listów do hoteli i restauracji, zarzucając im naruszenie patentu przez używanie technologii bezprzewodowej w celu udostępnienia Internetu swoim klientom ${ }^{42}$.

\section{Uezestnictwo kancelarii prawnych}

Podobieństwo omawianych konstrukcji wynika również z cechy, jaką jest uczestnictwo kancelarii prawnych i firm okołoprawniczych w procesie trollingu. P.R. Gigliuzza podaje przykłady działań przedsiębiorstw - trolli patentowych, jak CleOrv, DucPla and EntNil, które okazały się podrzędnymi innej spółki - MPHJ Technology Investments, kontrolowanej przez teksańskiego prawnika J. Mac Rusta.

W tym wypadku sposób działania trolli był następujący. W pierwszej kolejności przedsiębiorstwa otrzymywały list z informacją, że nadawca jest pośrednikiem licencyjnym właścicieli patentu dotyczącego korzystania w obszarze biura ze skanera, a następnie przesyłania zeskanowanych wiadomości droga mailowa. List zawierał stwierdzenie, że $\mathrm{z}$ dużą dozą prawdopodobieństwa nadawca korzysta $\mathrm{z}$ tego patentu,

${ }^{40}$ A. Rosen: The Big Lawsuits Keep..., s. 170.

${ }^{41}$ N. Mileszczyk: „Copyright trolling”...

${ }^{42}$ Orzeczenie United States District Court for the Northern District of Illinois, Eastern Division, Innovatio IP Ventures, LLC Patent Litigation, 886 F.Supp.2d 888 (N.D. Ill. 2012). 
dlatego powinien zawrzeć odpowiednią ugodę, w danej chwili w cenie „promocyjnej”, wynoszacej jedynie 1200 \$ za pracownika. Następnie większość nadawców otrzymywała dwa dodatkowe listy od teksańskiej kancelarii prawnej Farney Daniels. Pierwszy sugerował, że sprawa została przekazana do uprawnionego z patentu, którego przedstawiciele moga wszczać postępowanie sadowe. Drugie pismo natomiast już wprost zawierało klauzulę, że w sytuacji nieustosunkowania się w ciagu dwóch tygodni od dnia doręczenia listu mocodawca „będzie zmuszony” wnieść przeciwko adresatowi skargę o naruszenie patentu do Federal District Court $^{43}$.

W Polsce działalność trollingowa również skupia się głównie wokół kancelarii prawnych lub firm okołoprawniczych. Jako przykład podać można działalność adwokat A.Ł..4, Kancelarię L.S. ${ }^{45}$ czy też kancelarię prawna P.B. ${ }^{46}$ Pisma przygotowywane przez tych pełnomocników nie licują z powagą wykonywanego zawodu, ich treść jest niejasna i nie zawiera podstawy roszczenia ${ }^{47}$.

\section{Masowe rozsyłanie wezwań i wywołana reakcja}

Udział kancelarii prawnych w działalności trollingowej pozwala na wskazanie kolejnych podobieństw między omawianymi konstrukcjami. Po pierwsze, dochodzenie roszczeń przez rzekomego poszkodowanego odbywa się przez masowe rozsyłanie wezwań do zapłaty, często do przypadkowych osób. Po drugie, konstrukcja pism wywołuje w odbiorcy poczucie zagrożenia i stanowi formę nacisku.

Sformułowanie treści przekonuje odbiorcę, że korzystniejsze będzie dla niego przystanie na propozycję ugodową zawartą w piśmie niż wda-

${ }^{43}$ P.R. Gugliuzza: Patent Trolls and Preemption. „Virginia Law Review” 2015, vol. 101 , no. 6 , s. $1580-1581$.

${ }^{44}$ M. Maj: Kancelaria Anny Euczak chce czegoś więcej niż 550 zł za ściaganie filmu. Co z tym robić?, http://di.com.pl/kancelaria-anny-luczak-chce-czegos-wiecej-niz-550-zlza-sciaganie-filmu-co-z-tym-robic-50154 [Data dostępu: 28 stycznia 2018 r.].

${ }^{45}$ M. Maj: Kancelaria chce 750 zł od internautów i grozi „wnioskiem o przeszukanie”, http://di.com.pl/kancelaria-chce-750-zl-od-internautow-i-grozi-wnioskiem-oprzeszukanie-51399 [Data dostępu: 28 stycznia 2018 r.].

${ }^{46}$ M. Maj: Kancelaria chce 1116 zt za rozpowszechnianie H. Pottera... przed laty, http://di.com.pl/kancelaria-chce-1116-zl-za-rozpowszechnianie-h-pottera-przed-laty51927 [Data dostępu: 28 stycznia 2018 r.].

${ }^{47}$ O. Wrzeszcz: Trolling prawnoautorski..., s. 43. 
nie się w spór i związana z tym potrzeba analizy prawnej zaistniałej sytuacji ${ }^{48}$.

Sytuację dodatkowo pogarsza to, że nadawcami pism sa zawodowi prawnicy, natomiast ich odbiorcami w większości osoby nieposiadajacej wiedzy prawniczej i niedecydujace się na zasięgnięcie profesjonalnej porady. Kierowane w ramach trollingu pisma maja kategoryczny i zastraszający wydźwięk ${ }^{49}$. Powoływanie się na prowadzone postępowanie karne, odwoływanie się zarówno do środków cywilnych, jak i karnych mogą rodzić błędne przekonanie adresata, że od wniesienia przez niego opłaty uzależnione są wszystkie ewentualne postępowania prowadzone w związku z domniemanym naruszeniem, a decyzja o ich umorzeniu pozostaje jedynie w woli pełnomocnika i jego mocodawcy ${ }^{50}$.

Główną różnica pomiędzy trollingiem patentowym a trollingiem prawnoautorskim jest zakres wystosowywanej w kierunku odbiorcy groźby. Odnośnie do patentów jest to jedynie groźba poniesienia znacznej odpowiedzialności finansowej. Natomiast trochę inaczej możemy scharakteryzować groźbę zawartą w pismach trolli prawnoautorskich. Niejednokrotnie, oprócz zagrożenia odpowiedzialnością finansową, dodatkowo występuje groźba ujawnienia działania, które stanowiło naruszenie. Jak wcześniej wspomniano, prym wiedzie tu branża pornograficzna. W latach 2011-2013, kiedy to A. Rosen przedstawiła swoją analizę problemu copyright trollingu w przemyśle pornograficznym, liczba osób, którym grożono wszczęciem postępowania w Stanach Zjednoczonych w związku z naruszeniem prawa autorskiego do filmów pornograficznych, wyniosła ponad 200 tys. $^{51}$ Groźba wszczęcia postępowania sądowego w tej sytuacji była bardziej dotkliwa, z uwagi bowiem na jawność postępowania w stosunkowo łatwy sposób można by się dowiedzieć, jaki utwór został potencjalnie naruszony. Adresaci wezwań byli bardziej skłonni do zawierania ugód, gdyż obawiali się upokorzenia, reakcji społeczeństwa po otrzymaniu informacji, że naruszyli oni prawa autorskie do filmu pornograficznego ${ }^{52}$. Idea działania jest prosta, im bardziej film jest zawstydzający, tym większe prawdopodobieństwo, że naruszyciel zaakceptuje propozycję ugodowa, aby nie być kojarzonym z tego typu treściami ${ }^{53}$.

Dodatkowo w przypadku trollingu prawnoautorskiego potencjalni naruszyciele moga ponieść jeszcze jedną wyjątkowo uciążliwą konsekwencję. Wszczęcie postępowania karnego powoduje konieczność zgroma-

\footnotetext{
${ }^{48}$ M. Maj: Copyright trolling - raport...

${ }^{49}$ O. Wrzeszcz: Trolling prawnoautorski..., s. 43.

${ }^{50}$ N. Mileszczyk: „Copyright trolling”...

${ }^{51}$ A. Rosen: The Big Lawsuits Keep..., s. 170.

${ }^{52}$ Ibidem, s. 171.

${ }^{53}$ G.S. Mortenson: BitTorrent..., s. 1112.
} 
dzenia przez organy śledcze materiału dowodowego. Z tego też względu $\mathrm{w}$ toku postępowania organy te moga stwierdzić potrzebę zabezpieczenia twardego dysku lub całego komputera. Pozbawienie dostępu do komputera i zawartych na jego dysku danych oparte jedynie na ustalonym w watpliwy sposób adresie IP budzi kontrowersje.

Ostatnie już podobieństwo trollingu patentowego do trollingu prawnoautorskiego dotyczy wszczynania postępowań sądowych przez trolle, a raczej ich braku. Jeśli chodzi o patent trolling, to możemy się odnieść do wspomnianego wcześniej MPHJ Technology Investments. Przez wiele miesięcy po rozesłaniu listów z wezwaniem do zapłaty spółka nie wniosła ani jednego pozwu o naruszenie. Natomiast gdy zdecydowała się na wniesienie powództwa, natychmiast przyciągnęła uwagę prawników stanowych, którzy zaczęli badać sposób działania przedsiębiorstwa ${ }^{54}$.

\section{Podsumowanie}

$\mathrm{Z}$ uwagi na to, że copyright trolling niejako wywodzi się z patent trollingu między tymi konstrukcjami występują znaczne podobieństwa. Obie stanowią działalność, której celem jest bierne korzystanie z przysługujacych im praw, opierające się jedynie na uzyskiwaniu z nich korzyści majątkowych. Metodą mająca na celu uzyskanie jak największych dochodów jest masowe wysyłanie listów zawierajacych wezwanie do zapłaty lub próby ugodowej. Podstawa działalności trolli jest bazowanie na braku świadomości prawnej adresatów pism. Co wydaje się szczególnie dotkliwe, udział w tym procederze maja przedstawiciele zawodów prawniczych.

Nadal istnieje wiele wątpliwości odnoszących się trollingu. Do tej pory nie znaleziono skutecznego sposobu, aby sobie z nim radzić. Dotychczasowe działania nakierowane były na pociągnięcie do odpowiedzialności prawników-trolli. Jednak pojawianie się coraz to nowych podmiotów podejmujących tę działalność dowodzi, że wszczęcie pierwszych postępowań dyscyplinarnych wobec prawników-trolli nie przyniosło zamierzonego efektu.

Główną różnicę między copyright a patent trollingiem stanowi zakres groźby ujętej w pismach zawierających wezwanie do zapłaty. Trolle patentowe wywołuja jedynie groźbę odnoszacca się do poniesienia odpowiedzialności majątkowej. Natomiast działalność trolli prawnoautorskich

${ }^{54}$ P.R. Gugliuzza: Patent Trolls..., s. 1582. 
potęguje wywoływanie $\mathrm{w}$ odbiorcach zagrożenia ujawnieniem tak intymnych szczegółów, jak preferencje seksualne, lub też odebraniem im komputera na dłuższy, nawet wielomiesięczny okres, gdy niejednokrotnie stanowi on ich narzędzie pracy.

Określenie rozmiarów działalności copyright i patent trolli w Polsce jest niemożliwe. $\mathrm{Z}$ całą pewnością jednak należy uznać, że nie występują one na taką skalę, jak ma to miejsce w Stanach Zjednoczonych. Można jedynie wyrazić nadzieję, że w Polsce zjawisko to nie osiagnie tak znacznych rozmiarów. Wydaje się także, że coraz większa liczba osób jest świadoma istnienia trolli. Być może wzrost świadomości prawnej wśród użytkowników Internetu spowoduje, że cały proceder, z uwagi na przyjęcie postawy ignorującej przesłane listy, stanie się dla trolli nieopłacalny. 


\title{
Katarzyna Kluczka*
}

\section{Patent trolling w Wielkiej Brytanii}

\begin{abstract}
The main issue of this article is the current state of affairs concerning patent trolling in Great Britain. There is a possibility that this country might be the main focus of the activities of trolls in the future. Therefore, the description of the British patent system with a bit of a comparison with the American system hopefully can answer, why so far patent trolls were not fully successful in Great Britain. Moreover, the article briefly presents the most significant case so far in the matter of patent trolling in Great Britain which constitutes a precedent applying to standard-essential patents and FRAND rules. Furthermore, the problematic aspects of the establishment of a European patent with unitary effect as well as the Unified Patent Court arise. The new court may tempt patent trolls and simplify their actions. However, Great Britain does not remain idle. A new law has been introduced - Intellectual Property (Unjustified Threats) Act 2017. The purpose of the bill is to provide a protection against groundless threats of infringement proceedings.
\end{abstract}

Keywords: patent trolling, non-practicing entities, patent assertion entities, British law, British patent system, patent infringement, standard-essential patent, FRAND terms, FRAND injunction, Unified Patent Court, Intellectual Property (Unjustified Threats) Act 2017

\section{Wprowadzenie}

Patent trolling — w języku polskim trolling patentowy — to zjawisko stosunkowo nowe na obszarze Starego Kontynentu. Jak wynika z ba-

\footnotetext{
* Mgr, Uniwersytet Jagielloński w Krakowie.
} 
dań, w Stanach Zjednoczonych działania trolli zaczęły nabierać znaczenia w ostatniej dekadzie, Europa zaś do niedawna wydawała się na nie odporna ${ }^{1}$. Pojęcie to wywodzi się z mitologii nordyckiej; trolle przedstawiano tam jako istoty pożerające ludzi ${ }^{2}$, a także jako stworzenia żądające od podróżujących opłaty za bezpieczny przejazd przez most ${ }^{3}$.

Obecnie mianem trolle określa się podmioty, którym przysługują liczne prawa wyłączne - np. do wynalazków - a uzyskane patenty wykorzystywane sa jako narzędzie skutecznej perswazji czy zastraszania potencjalnych naruszycieli, w celu uzyskania przychodu przez zasądzenie odszkodowania bądź zawarcie ugody. Twórcą terminu troll patentowy jest Peter Detkin, prawnik pracujacy dla Intela. Zacytowane przez niego w artykule z 2001 r. pojęcie zrobiło oszałamiająca karierę ${ }^{4}$. Działania trolli patentowych sa szeroko zakrojone, dochodowe oraz zgodne z prawem; przysługuja im prawa wyłączne, jednak zapewniona instytucjami patentowymi ochrona jest przez nie nadużywana. Podmioty te, nabywszy portfolio patentów, wykorzystuja pozycję dominująca w celu blokowania konkurencji, m.in. wysuwając roszczenia ${ }^{5}$ i wytaczając powództwa przeciwko domniemanym naruszycielom ${ }^{6}$, jak również dążąc do nałożenia na potencjalnego naruszyciela tymczasowego nakazu sądowego czy pobierania od stron trzecich opłat licencyjnych?

Trolle patentowe zazwyczaj utożsamiane sa z tzw. PAE (patent assertion entities) ${ }^{8}$ bądź NPE (non-practicing entities): podmiotami, które

1 S. Fusco: Markets and Patent Enforcement: A Comparative Investigation of Non-Practicing Entities in the United States and Europe. „Michigan Telecommunications and Technology Law Review" 2014, vol. 20(2), s. 441.

${ }^{2}$ International Encyclopaedia of Laws: Cyber Law - United Kingdom. Wolters Kluwer 2017, Part II, Chapter 2, Explanation: Treatise, § 11.

${ }^{3}$ R.S. Katz, S.G. Hanson, O. Farooqui: Patent Trolls: A Selective Etymology. „IP Law 360" 20.03.2008 r.

${ }^{4}$ M. Reitzig, J. Henkel, C. Heath: On sharks, trolls, and their patent prey Unrealistic damage awards and firms' strategies of „being infringed”. „Research Policy” 2007, vol. 36(1), s. 135.

${ }_{5}^{5}$ M. Kubiak, w: Prawo własności przemysłowej. Komentarz. Red. A. Michalak. Warszawa 2016, komentarz do art. 285, teza IV.2. LEGALIS.

${ }^{6}$ Por. A. Nowicka, w: „System Prawa Prywatnego”. T. 14A: Prawo własności przemystowej. Red. R. Skubisz. Warszawa 2012, rozdz. III, §17.III. LEGALIS, a także R. Skubisz, w: „System Prawa Prywatnego”. T. 14A: Prawo własności przemysłowej. Red. R. Skubisz. Warszawa 2017, s. 116.

${ }^{7}$ Komunikat Komisji do Parlamentu Europejskiego, Rady i Europejskiego Komitetu Ekonomiczno-Społecznego Europejska strategia w zakresie praw własności przemysłowej, 16.07.2008, s. 9, http://eur-lex.europa.eu/legal-content/PL/TXT/PDF/?uri=CELEX: 52008DC0465\&from=PL [Data dostępu: 17 grudnia 2017 r.].

8 Twórcą terminu jest C.V. Chien. Zgodnie z jej definicją, PAE skupiają się na egzekwowaniu roszczeń zamiast na aktywnym rozwijaniu czy komercjalizacji patentów; cyt. za: B.J. Love, C. Helmers, F. Gaessler, M. Ernicke: Patent Assertion Enti- 
nie wytwarzają produktów ${ }^{9}$ ani nie rozwijają technologii. Powstaja wyłącznie w celu skupowania patentów i generowania dochodów przez powiązane z nimi opłaty licencyjne, uzyskane od nierzadko zastraszonych przedsiębiorców, którzy chca kontynuować korzystanie z technologii bez groźby przeprowadzenia postępowania sądowego w sprawie naruszenia patentu $^{10}$. NPE wytaczają powództwa przeciwko wielu podmiotom równocześnie i prowadząc agresywne negocjacje dążą do zawarcia ugody. Nie wytwarzaja żadnych produktów, a zatem nie są zagrożone powództwem wzajemnym w przedmiocie naruszenia patentu. Elementem strategicznym tych podmiotów jest zaskoczenie, często bowiem wysuwają roszczenia przeciwko znanym przedsiębiorstwom, które zdążyły już stworzyć i sprzedać produkt rzekomo naruszający prawa wyłączne ${ }^{11}$. Warto zauważyć, że uznanie wszystkich NPE za trolle jest nieco krzywdzące, gdyż do NPE należą także uniwersytety oraz start-upy technologiczne, które ex ante zawieraja umowy licencyjne $\mathrm{z}$ przedsiębiorstwami zamierzajacymi korzystać z opatentowanych wynalazków ${ }^{12}$ i mają istotne znaczenie dla transferu technologicznego ${ }^{13}$. Uniwersytetów zatem, chociaż mają wiele wspólnych cech z trollami, nie należy zaliczać do tej kategorii, podobnie jak innych podmiotów, które dążą do komercjalizacji wynalazków ${ }^{14}$.

\section{Wielka Brytania — zarys systemu patentowego}

Wielka Brytania — w kręgu common law jedyny europejski kraj posiadający system prawny w niektórych aspektach mający cechy wspólne

ties in Europe, 2015, s. 4, http://digitalcommons.law.scu.edu/facpubs/912 [Data dostępu: 29 grudnia 2017 r.].

9 J. Bessen, J. Ford, M.J. Meurer: The Private and Social Costs of Patent Trolls. „Regulation”, Winter 2011-2012, s. 26.

${ }_{10}$ International Encyclopaedia of Laws...

${ }_{11}$ C.V. Chien: Of Trolls, Davids, Goliaths, and Kings: Narratives and Evidence in the Litigation of High-Tech Patents. "North Carolina Law Review” 2009, vol. 87(5), s. 1579 .

12 A. Devlin: Improving Patent Notice and Remedies: A Critique of the FTC's 2011 Report. „Michigan Telecommunications and Technology Law Review” 2012, vol. 18(2), s. 545 .

${ }_{13}$ M.A. Lemley: Are Universities Patent Trolls? „Fordham Intellectual Property, Media and Entertainment Law Journal” 2008, vol. 18(3), s. 611, 629; cyt. za: A. Devlin: Improving Patent Notice and Remedies..., s. 545.

${ }_{14}$ B.J. Love, C. Helmers, F. Gaessler, M. Ernicke: Patent..., s. 4; więcej na ten temat M.A. Lemley: Are Universities..., zwłaszcza s. 629. 
z systemem Stanów Zjednoczonych — potencjalnie mogła stać się kolejnym obiektem zmasowanych ataków trolli patentowych. Sytuację w tym przedmiocie zbadano w latach 2000-2010. Ustalono, że w tej dekadzie w Wielkiej Brytanii NPE były inicjatorami 11\% wszystkich pozwów dotyczących patentów ${ }^{15}$, natomiast $\mathrm{w}$ Stanach Zjednoczonych w tym samym okresie przyczyniły się do około $25 \%$ powództw ${ }^{16}$. Warto jednak zauważyć, że na początku XX w. sytuacja w USA była pod tym względem podobna do obecnej w Wielkiej Brytanii, gdzie problem patent trollingu dopiero zaistniał ${ }^{17}$. Uzasadnione jest zatem pytanie, czy wobec przytoczonych danych statystycznych trolle sa problemem dla Wielkiej Brytanii? Jeśli odpowiedź jest negatywna, to co stanowi skuteczną blokadę przeciw trollom. Jakie istnieja zagrożenia? Poniżej zostanie przedstawiony zarys systemu patentowego Wielkiej Brytanii i poszczególne rozwiązania odróżniające go od systemu amerykańskiego, które mogą ułatwić rozstrzygnięcie wymienionych kwestii.

$\mathrm{Z}$ tradycji common law w brytyjskim postępowaniu patentowym wywodzą się takie elementy, jak: ustne przedstawienie dowodów, korzystanie $\mathrm{z}$ opinii biegłych wybieranych przez strony, przesłuchanie $\mathrm{w}$ krzyżowym ogniu pytań (cross-examination) czy wyrokowanie na podstawie precedensów ${ }^{18}$. Brytyjskie patentowe prawo materialne spełnia wymogi zawarte w Konwencji o udzielaniu patentów europejskich, jednakże kwestia uregulowana wyłącznie przez rodzime przepisy jest enforcement egzekwowanie. Warto zauważyć, że spośród wielu różnic pomiędzy standardami konwencyjnymi a systemem brytyjskim szczególnie istotne sa kryteria patentowalności - w Wielkiej Brytanii znacznie węższe niż te stosowane przez Europejski Urząd Patentowy ${ }^{19}$.

Podstawowy brytyjski akt prawny dotyczący ochrony wynalazczości stanowi wielokrotnie nowelizowany Patents Act 1977. Zgodnie z jego treścia, do uzyskania patentu niezbędne jest spełnienie takich wymogów, jak: nowość, nieoczywistość, posiadanie poziomu wynalazczego (involve an inventive step), jak również nadawanie się do przemysłowego stosowania $^{20}$. Zawarte sa w nim także wyjątki od patentowalności, w tym odnośnie do programów komputerowych. Jest to o tyle istotne, że według

15 B. Love, C. Helmers, L. McDonagh: Is there a patent troll problem in the UK? „Fordham Intellectual Property, Media and Entertainment Law Journal” 2015, vol. 24(2), s. 525 .

16 Ibidem.

${ }_{17}$ B.J. Love, C. Helmers, F. Gaessler, M. Ernicke: Patent..., s. 5.

18 T.F. Cotter: Comparative Patent Remedies: a legal and economic analysis. Oxford University Press 2013, s. 163.

${ }^{19}$ Ibidem, s. 164.

${ }^{20}$ Por. Patents Act 1977, c. $37 \S 1$ (1). 
badań McDonagha, Helmersa i Love'a, w przeważającej mierze powództwa wytoczone przez trolle dotyczyły nowych technologii (zwłaszcza informacyjnych i komunikacyjnych) i to w znacznie większym stopniu niż w Stanach Zjednoczonych ${ }^{21}$. Może to zastanawiać, zwłaszcza gdy bierze się pod uwagę, że w USA prawo nie przewiduje szczególnych wyjątków, jeśli chodzi o pantentowalność i nie wyklucza możliwości uzyskania patentu na oprogramowanie ${ }^{22}$. Zawierajac w Patents Act 1977 wyjatek od patentowalności, zakładający, że program komputerowy nie może zostać uznany za wynalazek, prezentowane jest znacznie surowsze podejście do software inventions niż w Stanach Zjednoczonych. Podobnie jak w Konwencji o udzielaniu patentów europejskich, w Wielkiej Brytanii programy komputerowe „jako takie” nie sa zatem patentowalne. Jednak inaczej jest w przypadku wynalazku wspomaganego komputerowo. Potwierdza to orzeczenie w sprawie Halliburton Energy Services, Inc v. Smith International (North Sea) Ltd, w którym sędzia stwierdził, że: „[a] computer programmed to perform a task which makes a contribution to the art which is technical in nature is a patentable invention and may be claimed as such" ${ }^{23}$. Bariery prawne, chociaż unowocześniane precedensami, nie zniechęcają trolli. Najgłośniejsze sprawy wytaczane przez NPE w ostatnich latach dotyczyły telefonii komórkowych sieci cyfrowych ${ }^{24}$.

W Wielkiej Brytanii w sprawach patentowych w I instancji właściwe sa cztery sady: the Patents Court oraz Intellectual Property Enterprise Court (IPEC - dawniej the Patents County Court) - oba z siedziba w Londynie, a także szkocki the Outer House of the Court of Session i High Court of North Ireland ${ }^{25}$. Pierwsze dwa sa sadami wyspecjalizowanymi; zasiadają w nich sędziowie doświadczeni w sprawach z zakresu własności intelektualnej (rutynowe jest honorowanie nominacjami sędziowskimi uznanych barristerów). Większość powództw wytaczana jest przed the Patents Court. Co do zasady, IPEC rozpoznaje sprawy, w których wysokość domaganej kwoty jest mniejsza niż 500 tys. $£$, a gdy suma ta zostanie przekroczona, sprawą zajmuje się the Patents Court. Jednak i w tym przypadku strony mogą podjąć decyzję, że to IPEC powinien roz-

${ }^{21}$ Por. B. Love, C. Helmers, L. McDonagh: Is there..., s. 516.

${ }^{22}$ Ibidem, s. 509-510; http://www.wipo.int/sme/en/documents/software_patents_ fulltext.html [Data dostępu: 17 grudnia 2017 r.].

${ }^{23}$ Por. https://www.gov.uk/guidance/manual-of-patent-practice-mopp/section-1-paten tability [Data dostępu: 18 grudnia $2017 \mathrm{r}$.].

${ }^{24}$ Zob. Nokia GMBH v. IPCom GMBH, [2010] EWHC (Pat) 791, [1] (Eng.) - sprawa dotyczyła telefonii GSM; Unwired Planet International Limited $v$. Huawei Technologies Co. Limited, Samsung Electonics Co. Limited, Google Inc and others, gdzie przedmiot sporu stanowiło m.in. wykorzystanie sieci $3 \mathrm{G}$.

25 T.F. Cotter: Comparative Patent Remedies..., s. 172. 
poznać sprawę. Dla żądań poniżej 10 tys. £ przewidziany jest specjalny tryb, tzw. small claims track ${ }^{26}$.

Postępowanie w Patents Court trwa 9-18 miesięcy, koszt prostych spraw wynosi $200-500$ tys. $£$, a w przypadku spraw skomplikowanych sięga 1 min $£$. W dawnym the Patents County Court postępowanie miało zajmować $6-9$ miesięcy i kosztować w granicach $20-100$ tys. $£^{27}$. Inne źródła szacuja, że suma kosztów obu stron w wyniku rozpoznania sprawy przez the Patents Court wynosi od 500 tys. $£$ do nawet $3 \mathrm{mln} £^{28}$. $\mathrm{Z}$ założenia postępowanie przed IPEC ma być krótsze i w konsekwencji tańsze od prowadzonego przed the Patents Court ${ }^{29}$. Koszty generowane są z uwagi na kompleksowość i wnikliwość brytyjskiego postępowania $\mathrm{w}$ sprawach patentowych. Wzywani sa biegli sadowi, przeprowadzane są eksperymenty procesowe; z powiązania sędziów i barristerów wynika kolejna cecha brytyjskiego postępowania - przeważa raczej model skargowy niż inkwizycyjny, co powoduje zwiększenie liczby przeprowadzanych przez strony dowodów ${ }^{30}$. Surowiej niż w innych krajach badana jest kwestia nieważności rzekomo naruszonego patentu. Chociaż koszty wciąż są niższe niż w Stanach Zjednoczonych (w Wielkiej Brytanii tańsza jest obrona, natomiast droższy koszt egzekwowania praw) ${ }^{31}$, krytykowane sa jako nadmierne.

Jednakże to właśnie z kwestia finansową wiąże się kluczowy element tamujacy trolle: fee shifting. W Wielkiej Brytanii obowiązuje tzw. loser-pays legal regime. Troll, decydujac się na wytoczenie powództwa, musi jednocześnie podjąć ryzyko pokrycia nie tylko własnych kosztów, lecz w przypadku przegrania sprawy - również przeciwnika. Zapłata zwycięskiej stronie powinna pokryć istotna część jej kosztów - zazwyczaj około 2/3 tej sumy ${ }^{32}$; obejmuje ona także attorney's fee, „rozsądne” wynagrodzenia barristers, solicitors czy rzeczników patentowych na podstawie cen rynkowych, nie zaś prawnie, z góry wykonanych obliczeń ${ }^{33}$.

${ }^{26}$ https://www.gov.uk/courts-tribunals/intellectual-property-enterprise-court [Data dostępu: 18 grudnia 2017 r.].

${ }_{27}$ www.dyoung.com/knowledgebank/articles/patentrevocation [Data dostępu: 27 grudnia 2017 r.].

${ }_{28}$ B. Love, C. Helmers, L. McDonagh: Is there..., s. 540.

${ }_{29}$ Ibidem, s. 517; odmiennie W. Cornish, D. Llewelyn: The Enforcement of Patent Rights in the United Kingdom. In: Patent enforcement worldwide: a survey of 15 countries: writings in honour of Dieter Stauder. Eds. C. Heath, L. Petit. Hart Publishing 2005, s. 89.

${ }^{30}$ W. Cornish, D. Llewelyn: The Enforcement..., s. 91.

${ }^{31}$ B. Love, C. Helmers, L. McDonagh: Is there..., s. 511-512.

32 Taką część kosztów musiało uiścić np. IPCom, jako strona przegrana w postępowaniu przeciwko Nokii.

${ }^{33}$ W. Cornish, D. Llewelyn: The Enforcement..., s. 91. 
Koszt taki zazwyczaj wynosi od 250 tys. £ wzwyż i stanowi częstszy rezultat niż przyznanie trollom damages (zbiorcza nazwa środków ochrony pieniężnej - pol. odszkodowanie) czy uzyskanie korzyści finansowych przez zawarcie ugody ${ }^{34}$. W Wielkiej Brytanii nie jest dozwolone contigency fee, czyli zapłata prawnikowi tylko w wypadku wygranej, co praktykowane w Stanach Zjednoczonych powoduje, że w konsekwencji każdy NPE może podjacć działania bez zagrożenia obciążeniem finansowym w razie niepowodzenia w sądzie ${ }^{35}$.

Istotne jest odrzucenie przez Wielką Brytanię doktryny ekwiwalentów $^{36}$. Od wyroku w sprawie Catnic $^{37}$ z 1981 r. w postępowaniu w przedmiocie naruszenia patentu zadawano trzy pytania, które miały wyeliminować ryzyko wynikające z rygorystycznego stosowania wykładni literalnej, jak również niepewność powodowana stosowaniem doktryny ekwiwalentów. Zgodność z art. 69 Konwencji o udzielaniu patentów europejskich potwierdziła decyzja Izby Lordów w sprawie $K i$ rin-Amgen Inc. v. Hoechst Marion Roussel Limited; podejście celowościowe przeważa zatem do dziś i stanowi jedna z istotnych odrębności systemu brytyjskiego. Najciekawsze, a zarazem wyróżniające jest trzecie pytanie - decydujące o interpretacji przez sąd żądań uprawnionego $\mathrm{z}$ patentu. Zakłada ono obiektywne spostrzeżenie specjalisty $\mathrm{w}$ danej dziedzinie w celu ustalenia, jak fachowiec rozumie treść zastrzeżenia patentowego ${ }^{38}$. W wyniku przyjęcia szerokiej interpretacji zastrzeżeń pozwany może poprzeć swoją obronę zarzutem nienależytego ujawnienia wynalazku ${ }^{39}$. Łączy się to z faktem, że w Wielkiej Brytanii — także dzięki wyspecjalizowanym sędziom - sąd jest właściwy w sprawach patentowych zarówno do rozpatrzenia kwestii naruszenia patentu, jak i jego nieważności ${ }^{40}$. W efekcie sędzia nierzadko dokonuje porównania nie tylko wynalazku i produktu, który rzekomo narusza patent, lecz również wynalazku i stanu techniki. Potencjalny naruszyciel może się bronić, że jego produkt nie jest ani nowy, ani nieoczywisty w świetle będącego podstawą udzielenia patentu stanu techniki, a zatem patent

${ }^{34}$ B. Love, C. Helmers, L. McDonagh: Is there..., s. 516.

${ }^{35}$ A. Johnson: Looking Forward: A User Perspective. In: J. Pila: The unitary EU patent system. Eds. J. Pila, C. Wadlow. Hart Publishing 2015, s. 179.

${ }^{36}$ Por. T.F. Cotter: Comparative Patent Remedies..., s. 171 oraz M. du Vall: Prawo patentowe. Warszawa 2008, s. 244-246.

${ }_{37}$ Catnic Components Ltd v. Hill \& Smith Ltd.

38 T.F. Cotter: Comparative Patent Remedies..., s. 171.

${ }^{39}$ Por. W.R. Cornish: The Practice in the UK. In: Interpretation of Patents in Europe. Application of Article 69 EOC. Eds. J. Pagenberg, W. Cornish. Heymanns Verlag Gmbh 2006, s. 225, 246; cyt. za: M. du Vall: Prawo patentowe..., s. 255.

${ }^{40}$ W. Cornish, D. Llewelyn: The Enforcement..., s. 90. 
powinien zostać unieważniony ${ }^{41}$. Uzasadnieniem takiego podejścia jest chęć ochrony przed słabymi patentami, co ma odstraszać potencjalnych wynalazców od zamiaru ich uzyskania.

Prewencyjnym rozwiazaniem wybieranym przez potencjalnych naruszajacych $\mathrm{w}$ Wielkiej Brytanii jest revocation action (to revoke to $\mathrm{w}$ brytyjskim żargonie patentowym odpowiednik to invalidate — unieważnić). Stanowi ona specyficzny pozew patentowy, który może zostać wniesiony jako counterclaim (powództwo wzajemne), jednakże szczególnym zastosowaniem jest jej użycie przed wprowadzeniem nowego produktu na rynek, gdy nie podniesiono jeszcze zarzutu naruszenia. Ma na celu uzyskanie „deklaracji braku naruszenia” (declaration of non-infringement) ${ }^{42}$, a także unieważnienie patentu konkurenta, w razie gdyby zdecydował się on dochodzić roszczeń za zarzucane naruszenie. Podstawy do uznania patentu za nieważny to: niemożność patentowalności wynalazku (non-patentability), brak tytułu prawnego do uzyskania patentu (non-entitlement), brak wystarczającego opisu wynalazku, który umożliwiałby jego reprodukcje przez fachowca (insufficiency), rozszerzanie zakresu zastrzeżenia patentowego (added matter) oraz niedozwolone przedłużenie ważności patentu (unallowable post-granted extension) ${ }^{43}$. Warto zauważyć, że w Wielkiej Brytanii w latach 2000-2010 aż 61\% postępowań z udziałem NPE zapoczątkowanych zostało przez potencjalnych naruszycieli, gdy tymczasem w Stanach Zjednoczonych liczba ta wynosi zaledwie $14-15 \%{ }^{44}$.

Revocation ma na celu wyeliminowanie ryzyka nałożenia na niekorzyść domniemanego naruszyciela $\mathrm{w}$ ewentualnym sporze sąowym injunction - sądowego nakazu/zakazu należącego do interim reliefs ('́rodków ochrony tymczasowej). Interim reliefs, zwane także remedies, dzielone na pieniężne i niepieniężne, w teorii powinny wynagrodzić straty uprawnionych z patentu, a nie stanowić karę dla oskarżonych o naruszenie. W rzeczywistości remedies są niezwykle efektywnym narzędziem wymierzonym przeciwko potencjalnym naruszycielom; niektórzy wręcz uznają, że ich celem jest ustanowienie „punktów zagrożenia” wpływajacych korzystnie (dla właścicieli praw) na toczące się negocjacje w przed-

${ }^{41}$ W.R. Cornish: The Practice..., s. 225.

${ }^{42}$ Tribunal Patents Manual (online version), https://www.gov.uk/guidance/litiga tion-manual/chapter-13-section-71-declaration-as-to-non-infringement [Data dostępu: 28 grudnia 2017 r.].

${ }^{43}$ www.dyoung.com/knowledgebank/articles/patentrevocation, https://www.gov.uk/ guidance/manual-of-patent-practice-mopp/section-72-power-to-revoke-patents-on-appli cation [Data dostępu: 26 grudnia 2017 r.].

${ }^{44}$ B. Love, C. Helmers, L. McDonagh: Is there..., s. 535. 
miocie umów licencyjnych ${ }^{45}$. Docelowo środek ten winien skutecznie zniwelować szkody dokonane przez domniemanego naruszyciela, jednakże w rękach trolli stanowi niebezpieczna broń, dzięki której zyskuja one wręcz nadmierna przewagę. Do standardowych środków wykorzystywanych w postępowaniach dotyczących naruszenia patentu zaliczyć należy: środki niepieniężne - jak injunctions czy declaratory judgement (wiażące ustalenie sądu, rozwiązujące prawną niewiadomą dla stron), oraz środki pieniężne - np.: lost profits (utracony zysk), reasonable royalties (rozsądne tantiemy) i accounting of defendant's profits ${ }^{46}$. Injunction to środek niezwykle pożądany przez uprawnionych z patentu, może bowiem oznaczać dla konkurenta nakaz wstrzymania sprzedaży, produkcji, importu, dystrybucji czy marketingu. W efekcie nakazu potencjalnego naruszyciela można doprowadzić nawet do bankructwa, mimo braku udowodnienia dokonania naruszenia; w świetle prawa następuje eliminacja nierzadko uczciwego przedsiębiorcy. Taki rezultat występował często w Stanach Zjednoczonych (do 2006 r., w którym wydano jednomyślna decyzję w sprawie eBay Inc. v. MercExchange, L.L.C); jeśli nie zaistniały nadzwyczajne okoliczności, właściwie zawsze wydawano nakaz na niekorzyść potencjalnego naruszyciela ${ }^{47}$. W Wielkiej Brytanii sądy wciaż sa niechętne przyznawaniu tymczasowych nakazów, jednakże rzadko odmawiają permanent injuctions (stałych zakazów) zwycięskim patent owners $^{48}$.

\section{Trolle w akcji: sprawa Unwired Planet International v. Huawei Technologies, Samsung and Google, Jednolity Sąd Patentowy oraz Intellectual Property (Unjustified Threats) Act 2017}

Fakt, że L. McDonagh, C. Helmers i B. Love prowadzili badania już w latach 2000-2010 dowodzi, że oznaki zwiastujące początek inwazji

${ }_{45}$ M. Schankerman, S. Scotchmer: Damages and injunctions in protecting intellectual property. „RAND Journal of Economics” Spring 2001, vol. 32(1), s. 201.

${ }_{46}$ T.F. Cotter: Comparative Patent Remedies..., s. 174.

${ }^{47}$ J.S. Helm: Why Pharmaceutical Firms Support Patent Trolls: The Disparate Impact of Ebay $v$. Mercexchange on Innovation. „Michigan Telecommunications and Technology Law Review" 2006, vol. 13(1), s. 331.

48 T.F. Cotter: Comparative Patent Remedies..., s. 175. 
trolli na Wielką Brytanię pojawiały się od ponad dekady. Zapowiedzią poważnych problemów okazała się głośno komentowana sprawa Unwired Planet International v. Huawei Technologies, Samsung and Google. Unwired Planet, zgodnie z taktyka stosowana przez znaczna liczbę trolli, nabyło patenty od zmagajacego się z problemami finansowymi podmiotu ${ }^{49}$ — w tym przypadku szwedzkiego Ericssona. Przejęte portfolio, zawierające tysiące patentów, umożliwiło wystąpienie na drogę sądową przeciwko przedsiębiorstwom gigantom. Unwired Planet pierwotnie bezskutecznie domagało się roszczeń od Apple w Stanach Zjednoczonych, jednak dopiero pozywajac Huaweia, Samsunga oraz Google i inicjując jednoczesne postępowania przed sądem niemieckim i brytyjskim, udowodniło realne istnienie rywalizacji pomiędzy tymi jurysdykcjami, związane ze zjawiskiem forum shoppingu ${ }^{50}$. Sprawa Unwired dotyczy branży telekomunikacyjnej i łączy się z użyciem telefonicznej sieci 3G, jak również SEP (standard-essential patent), tzw. patentami istotnymi, chroniącymi rozwiązania niezbędne dla stosowania danego standardu technicznego, komplementarne względem pozostałych, dla których nie można wskazać rozwiązań substytucyjnych ${ }^{51}$.

Uznanie patentu za SEP wiąże się ze znacznymi korzyściami dla uprawnionego $\mathrm{z}$ patentu. Wówczas każdy podmiot pragnący opracować produkt musi osiagnnąc porozumienie finansowe z poszczególnymi uprawnionymi z patentów, by legalnie wykorzystać osiągnięcia technologiczne. Ważne jest wymierzenie balansu pomiędzy uprawnionymi a szerszą społecznościa, pragnąca korzystać ze zdobyczy technologii ${ }^{52}$. Stanowi to jedno z zadań Europejskiego Instytutu Norm Komunikacyjnych (ETSI). Co istotne, podmiot, którego patent wchodzi w skład technologii, musi się zobowiąać do składania standardowych ofert udzielenia licencji z zachowaniem warunków FRAND (fair, reasonable, and non-discriminatory terms).

W sprawie Unwired nie podważano faktu złożenia ofert licencyjnych, zarzucano jednak ich sprzeczność z warunkami FRAND i negowano ważność rzekomo naruszonych patentów. W tych okolicznościach wniosek Unwired Planet o wydanie summary judgement (wyroku bez prze-

${ }^{49}$ A.J. Davis, K. Jesien: The Balance of Power in Patent Law: Moving Towards Effectiveness in Addressing Patent Troll Concerns. „Fordham Intellectual Property, Media and Entertainment Law Journal" 2015, vol. 22(4), s. 836.

${ }^{50} \mathrm{https}$ //www.carpmaels.com/court-battle-over-unwired-planet-patents-continues/ [Data dostępu: 26 grudnia 2017 r.].

${ }^{51}$ M. Kępiński, J. Ożegalska-Trybalska, A. Szewc, R. Sikorski, K. Szczepanowska-Kozłowska, T. Targosz, A. Tischner, w: „System Prawa Handlowego”. T. 3: Prawo wtasności przemysłowej. Red. E. Nowińska, K. Szczepanowska-Kozłowska. Warszawa 2015, rozdz. 3.6.10.5.2. LEGALIS.

${ }^{52}$ International Encyclopaedia of Laws... 
prowadzenia rozprawy) na podstawie dotychczasowych ustaleń został uznany za przedwczesny, prowadzenie dalszego postępowania zaś - za niezbędne. Sprawę uznano za tak skomplikowaną, że zdecydowano się na rozdzielenie poszczególnych kwestii do osobnego rozpoznania w serii trzech technical trials i trzech non-technical trials ${ }^{53}$. Natomiast Samsung (w 2015 r.) oraz Google (rok później) zdecydowały się na zawarcie z Unwired Planet ugody ${ }^{54}$.

Kluczowe zagadnienie, a zarazem deal-breaker dla Huaweia stanowił zasięg licencji. Huawei pragnął uzyskać licencję obejmujacca teren Wielkiej Brytanii, Unwired Planet zaś było skłonne jedynie do przyznania licencji światowej, której ofertę Huawei konsekwentnie odrzucał. W kwietniu 2017 r., po uznaniu dwóch patentów za ważne, a naruszenia za dokonane, wydano wyrok - sąd zdecydował, że światowa licencja zachowuje warunki FRAND ${ }^{55}$. Huawei, zagrożony nałożeniem injunction, zarzucał Unwired Planet stosowanie praktyk antykonkurencyjnych. Podmiot ten $\mathrm{w}$ istocie uznano za posiadający pozycję dominująca na rynku licencjonowania SEP, ale w opinii sądu jedynie nadużywanie tej pozycji mogłoby stanowić skuteczną obronę. Działania Unwired Planet określono jako zgodne z prawem, zdecydowano więc o wydaniu injunction: jeśli na poczet Unwired nie zostana uiszczone opłaty licencyjne, Huaweiowi grozi wstrzymanie sprzedaży produktów na terenie Wielkiej Brytanii ${ }^{56}$.

Przeciwdziałając negatywnemu wpływowi zastosowanego środka na dalsze negocjacje i spory dotyczące warunków licencji w przyszłości, sędzia Birss ustanowił nowy rodzaj injunction - tzw. FRAND injunc$t_{i o n^{57}}$. Zawiera on klauzule utraty mocy obowiąujaccej w przypadku zawarcia licencji FRAND, jak również swobody stron do powrotu przed sąd $\mathrm{w}$ przypadku utraty ważności licencji ${ }^{58}$. Po raz pierwszy ustalono kompleksową ocenę zastosowania reguł FRAND w powiązaniu z licencjonowaniem SEP. Sąd zezwolił Huaweiowi na odwołanie się do the Court

${ }^{53}$ P. Picht: Unwired Planet $v$. Huawei: A Seminal SEP / FRAND decision from the UK. „Journal of Intellectual Property Law \& Practice” 2017, vol. 12(10), s. 867, https:// www.vennershipley.co.uk/resources/news/2016/11/18/latest-developments-in-disputebetween-unwired-planet-and-samsung-before-th [Data dostępu: 26 grudnia $2017 \mathrm{r}$.].

${ }^{54}$ Ibidem, s. 868.

55 https://www.lexology.com/library/detail.aspx?g=28155442-4e8a-46d8-8b965f1f9e97a1f3 [Data dostępu: 27 grudnia 2017 r.].

56 https://www.eip.com/us/updates/article/high_court_rules_injunction_should_be_ granted_against_huawei_in_unwired_planet_frand_action/ [Data dostępu: 27 grudnia 2017 r.].

${ }^{57} \mathrm{https} / /$ www.lexology.com/library/detail.aspx?g=dff5d4f3-b6e8-4edd-8cd1-f2a f2e81f240 [Data dostępu: 28 grudnia 2017 r.].

58 https://www.vbb.com/insights/competition/english-high-court-issues-frand-injunc tion-in-dispute-involving-standard-essential-patents [Data dostępu: 27 grudnia 2017 r.]. 
of Appeal. Wykonanie nałożonego FRAND injunction jest więc zależne od rozstrzygnięcia apelacji, zawieszenie jednak uwzględnia zapłatę stosownych tantiemów dla Unwired Planet. Ostateczne zakończenie sprawy wciąż jest zatem odległe, jednakże eksperci podaja przykład Unwired Planet jako przełomowy; ze względu na zwycięstwo na tak wielką skalę podmiot ten stał się dla innych trolli pionierem.

W Zjednoczonym Królestwie liczne dyskusje wywołały plany utworzenia systemu patentu europejskiego o jednolitym skutku; to właśnie blokadę przystąpienia do niego przedstawiano jako jedną z motywacji do głosowania „za” tzw. Brexitem w referendum z dnia 23 czerwca 2016 r. Zwracano uwagę, że istnieje prawdopodobieństwo wzrostu liczby postępowań z udziałem trolli patentowych ${ }^{59}$, jak również popularności forum shoppingu - „wypróbowywania” poszczególnych oddziałów Jednolitego Sądu Patentowego rozmieszczonych w różnych państwach. Obawiano się „federalizacji” Europy i egzekwowania jednolitego patentu na terenie całego kontynentu za pomoca jednego postępowania na wzór Stanów Zjednoczonych (gdzie można wystąpić z powództwem w sądzie rejonowym miejscowo właściwym dla pozwanego i domagać się roszczeń na skalę krajowa, bez konieczności składania pozwu w każdym ze stanów z osobna ${ }^{60}$. W wyniku brytyjskiego referendum utworzenie Jednolitego Sądu Patentowego i systemu jednolitej ochrony patentowej stanęło pod znakiem zapytania. Warunkiem koniecznym do wejścia w życie Porozumienia z dnia 19 lutego 2013 r. w sprawie Jednolitego Sądu Patentowego [dalej: porozumienie JSP] jest bowiem jego ratyfikacja przez co najmniej 13 państw, w tym Francję, Niemcy oraz Wielka Brytanię - na mocy art. 89 ust. 1 tego porozumienia ${ }^{61}$. Rząd brytyjski zapowiedział rozpoczęcie procedury przygotowującej do ratyfikacji porozumienia $\mathrm{JSP}^{62}$; uzasadnione jest zatem pytanie o jej celowość, skoro Jednolity Sąd Patentowy miał wzmocnić ochronę patentową w obrębie państw członkowskich UE, do których Wielka Brytania nie będzie należeć. Do momentu wejścia w życie umowy o wystąpieniu Wielkiej Brytanii z Unii Europejskiej ratyfikacja porozumienia JSP jest możliwa; konieczne będzie natomiast wprowadzenie w nim licznych zmian, np. dotyczących dopuszczalności rozciągnięcia systemu ochrony na kraj niebędący państwem członkowskim UE, w celu umożliwienia działania

${ }^{59}$ L. McDonagh: European Patent Litigation in the Shadow of the Unified Patent Court. Edward Elgar Publishing 2016, s. 7.

${ }^{60}$ B. Love, C. Helmers, L. McDonagh: Is there..., s. 511-512, 514.

${ }^{61}$ A. Nowicka, w: „System Prawa Prywatnego”. T. 14A: Prawo własności przemystowej. Red. R. Skubisz [2017], s. 240—241, 254-255.

${ }^{62} \mathrm{https} / / \mathrm{www}$.gov.uk/government/news/uk-signals-green-light-to-unified-patentcourt-agreement [Data dostępu: 18 grudnia 2017 r.]. 
Jednolitego Sądu Patentowego po opuszczeniu Wspólnoty przez Wielką Brytanię.

Kolejną komplikację, a zarazem komponent ewentualnych zmian porozumienia JSP stanowi planowane umieszczenie w Londynie jednej z filii oddziału centralnego Jednolitego Sądu Patentowego ${ }^{63}$. Do końca 2017 r. Wielka Brytania jednak nie dokonała ratyfikacji porozumienia JSP; opóźnienie nastąiło z uwagi na zamknięcie obrad brytyjskiego parlamentu już w kwietniu 2017 r. w związku z wyborami, które odbyły się czerwcu $2017 \mathrm{r}^{6}{ }^{64}$ Warto zaznaczyć, że w pracach poczyniono od tego momentu znaczne postępy. Konieczne jest jeszcze wydanie zaledwie dwóch aktów prawnych. Pierwszy z nich - rozporządzenie The International Organisations (Immunities and Privileges) (Scotland) Amendment (No. 2) Order 2017 (projekt, drogą delegacji ustawowej, przygotowali szkoccy ministrowie) - został zatwierdzony przez Tajna Radę Królewska dnia 13 grudnia $2017 \mathrm{r} .{ }^{65}$ Drugim aktem prawnym jest projekt rozporządzenia będącego ekwiwalentem szkockiego Unified Patent Court (Immunities and Privileges) Order 2017. Nadal nie został on zatwierdzony przez Tajną Radę Królewska ${ }^{66}$. W konsekwencji, w razie pomyślnego rezultatu, możliwe będzie podpisanie ratyfikacji porozumienia JSP oraz Protokołu w sprawie przywilejów i immunitetów (Protocol on Privileges and Immunities of the Unified Patent Court). Stan zawieszenia może jednak trwać nawet do zawarcia umowy o wystapieniu z Unii Europejskiej, zgodnie $\mathrm{z}$ wytycznymi zawartymi w art. 50 ust. 2 Traktatu o Unii Europejskiej ${ }^{67}$.

Można się spodziewać, że po ratyfikacji porozumienia JSP reakcje brytyjskich ekspertów będą sceptyczne, jeśli nie wysoce krytyczne — jak miało to miejsce po ogłoszeniu planów utworzenia nowego systemu ochrony. Wśród cech jednolitego patentu dopatrywano się „furtek” dla trolli, m.in. w postaci wprowadzenia dwutorowości (bifurcation) i rozdzielenia rozpoznawania spraw o naruszenie oraz spraw o unieważnienie patentu. Wskazywano, że wprowadzenie dwutorowości stwarza ryzyko zezwolenia na egzekwowanie nieważnych patentów ${ }^{68}$. Ostrzegano też, że trollom

${ }^{63}$ https://www.unified-patent-court.org/locations [Data dostępu: 18 grudnia 2017 r.].

${ }^{64}$ http://patentblog.kluweriplaw.com/2017/04/28/delays-for-uk-ratification-unifiedpatent-court-agreement-and-start-unitary-patent-system/ [Data dostępu: 18 grudnia 2017 r.].

${ }^{65} \mathrm{https}$ ///www.bristowsupc.com/latest-news/uk's-privy-council-approves-draft-upcorder/, tekst rozporządzenia http://www.legislation.gov.uk/ssi/2017/447/contents/made [Data dostępu: 18 grudnia 2017 r.].

${ }^{66}$ Ibidem, tekst projektu rozporządzenia http://www.legislation.gov.uk/ukdsi/2017/ 9780111158555/contents [Data dostępu: 18 grudnia 2017 r.].

67 Traktat o Unii Europejskiej. Dz.U. 2004, nr 90, poz. 864/30 z późn. zm.

${ }^{68}$ A. Johnson: Looking Forward..., s. 189. 
ułatwi się pozywanie wielu podmiotów naraz. Na Starym Kontynencie w przypadku trolli można już było obserwować zjawisko tzw. forum shoppingu, chociażby w sprawie Unwired, jednakże można założyć, że ograniczenie dla wielu NPE na terenie Europy stanowiły koszty wytoczenia powództwa w poszczególnych państwach z osobna. W konsekwencji utworzenia jednolitej ochrony patentowej wystarczy, że troll złoży jedno powództwo, by domagać się roszczeń na podstawie rzekomego naruszenia praw wyłącznych we wszystkich państwach członkowskich związanych porozumieniem JSP. Prawdopodobnie „treść praw wyłącznych i ich ograniczenia będą takie same we wszystkich tych państwach" ${ }^{69}$, co także stanowi ułatwienie dla trolli patentowych, które nie będą musiały zasięgać profesjonalnych porad w sprawie systemów patentowych poszczególnych państw. Dodatkowo patent europejski o jednolitym skutku uzyskać będa mogły podmioty z całego świata, co stanowi gigantyczną wręcz zachętę np. dla amerykańskich trolli.

Rezultatem wciąż istniejącej perspektywy wdrożenia systemu patentu jednolitego oraz coraz częstszych nadużyć uprawnionych z praw wyłacznych jest nowa ustawa - Intellectual Property (Unjustified Threats) Act 2017, która weszła w życie dnia 1 października 2017 r. ${ }^{70}$ Cel tego nowego aktu prawnego stanowiło uściślenie, jaki rodzaj komunikacji między stronami jest dozwolony w sporze o naruszenie własności intelektualnej, jak również ustanowienie balansu między interesami posiadaczy praw wyłącznych a przedsiębiorców będących potencjalnymi naruszycielami. Treść ustawy odnosi się nie tylko do patentów i zawiera wytyczne dotyczace informowania domniemanego sprawcy przez podmiot uprawniony o dokonanym naruszeniu. Tytułowe unjustified threat odnosi się do sytuacji, w której zawiadomienie zawiera groźbę wytoczenia powództwa, a - odnosząc się do wynalazków - powoływane prawo nie istnieje, patent jest nieważny lub upłynął okres ochrony bądź też przez wskazane działanie wcale nie doszło do naruszenia ${ }^{71}$. W przypadku nadużycia wystosowanie owej „bezpodstawnej groźby” uznawane jest za nieuczciwe zastraszanie, a adresat zawiadomienia może na drodze sądowej ubiegać się o uzyskanie injunction i zabronienie nadsyłania następnych gróźb bądź też wystąić o zasądzenie damages ${ }^{72}$. Ustawa wprowadza także wiele

69 A. Nowicka, w: „System Prawa Prywatnego”. T. 14A: Prawo własności przemystowej. Red. R. Skubisz [2017], s. 276.

${ }^{70}$ The Intellectual Property (Unjustified Threats) Act 2017 Business Guidance, https://www.gov.uk/government/uploads/system/uploads/attachment_data/file/633353/ unjustified-threats-act-guidance-for-business.pdf [Data dostępu: 27 grudnia 2017 r.].

${ }^{71} \mathrm{https}$ ://www.gov.uk/government/publications/ip-unjustified-threats-act-for-smes/ ip-unjustified-threats-act-for-smes [Data dostępu: 27 grudnia 2017 r.].

${ }^{72}$ https://www.twobirds.com/en/news/articles/2017/uk/it-and-ip-law-bytes-june- 
innych kluczowych zmian, jednakże opisanie ich nie jest celowe w przedmiocie niniejszej rozprawy.

\section{Podsumowanie}

Zjawiska patent trollingu nie należy bagatelizować. Wobec istniejacego zagrożenia - choć zostało ono w Wielkiej Brytanii stosunkowo wcześnie zidentyfikowane - narasta potrzeba dalszych niż tylko zawartych w Intellectual Property (Unjustified Threats) Act 2017 przeciwdziałań. Obecnie rozwój działań trolli patentowych ograniczają kwestie finansowe; tańsze koszty obrony, większe nakłady finansowe na egzekwowanie praw, jak również niesięgające poziomu amerykańskiego kwoty odszkodowań czynią Wielką Brytanię krajem „mniej atrakcyjnym” dla trolli. Przyznawanie attorney's fee i konieczność pokrycia przez stronę przegraną nie tylko kosztów własnych, lecz także przeciwnika, w połączeniu z zakazem contigency fee, powoduja, że podjęcie ryzyka i zmierzenie się z konsekwencjami ewentualnej porażki stają się dla trolla nieopłacalne. Kolejny czynnik zniechęcajaccy trolle stanowi brak możliwości opatentowania programów komputerowych ,jako takich”. Dodatkowo niezwykle wysoki jest odsetek unieważnień patentu na skutek obrony pozwanego lub samoistnie, na drodze revocation action, która stanowi skuteczne narzędzie prewencyjne dla przedsiębiorców. Wraz z prowadzonymi, mimo widma Brexitu, pracami nad wdrożeniem jednolitego patentu europejskiego i wdrożeniem nowego systemu dotychczas skutecznie funkcjonujace bariery moga zawieść. Jest bardzo prawdopodobne, że w początkowym okresie działania Jednolitego Sądu Patentowego większość stron postępowania stanowić będą trolle bądź podmioty dążące do unieważnienia patentu na obszarze całej Europy ${ }^{73}$. Trolle niewatpliwie zachęci możliwość uzyskania injunctions, obejmujących swym zasięgiem teren kontynentu ${ }^{74}$, czy też nadzieja, że w obliczu niepewnego rezultatu prostsze stanie się nakłonienie konkurentów do zawarcia ugody. O ile jednak w nowym systemie zostanie wprowadzony w życie zamiar, by przyznawać wygranej stronie attorney's fee, obawy związane z opanowaniem Jednolitego Sądu Patentowego przez trolle mogą wydać się wyolbrzymio-

2017/intellectual-property-unjustified-threats-act-2017 [Data dostępu: 27 grudnia 2017 r.].

73 A. Johnson: Looking Forward..., s. 179.

74 http://patentblog.kluweriplaw.com/2015/12/14/unified-patent-court-could-createtrue-checks-and-balances-in-european-patent-law/ [Data dostępu: 27 grudnia 2017 r.]. 
$\mathrm{ne}^{75}$, a o wpływie nowego systemu na działalność trolli będzie się można przekonać dopiero po upływie kilku miesięcy od rozpoczęcia działalności Jednolitego Sądu Patentowego. Na aktywność trolli oddziaływać także będzie niewątpliwie wystąpienie Wielkiej Brytanii z Unii Europejskiej; do tego czasu jednak kraj ten powinien rozważyć wdrożenie nowych rozwiązań zwalczających patent trolling, na wzór serii ustaw uchwalonych w Stanach Zjednoczonych ${ }^{76}$.

${ }^{75}$ B. Love, C. Helmers, L. McDonagh: Is there..., s. 516.

${ }^{76}$ Ibidem, s. 513. 


\title{
Joanna Radziszewska*
}

\section{Copyright trolling a prawo cytatu}

\begin{abstract}
Article 29 of the Act of 4 February, 1994 on Copyright and Neighbouring Rights establishes institution called "citing right". This regulation shows conditions which must be met by person using somebody's work within this legal construction. First of all the cite must be recognizable and distinctly marked in the work where it appears. The manner of editing article 29 by putting into it unsharp and undefined terms, causes that everytime when it is used, his scope needs individual interpretation, taking into consideration all connected circumstances. Such a situation creates basis to use or even to abuse citing right by copyright trolls. Copyright trolling is new phenomenon which development has proceeded gradually, together with Internet expansion. By this time it hasn't neither his own legal definition, nor statutory regulation in Polish law. It consists in mass sending final payment demands which purpose is to gain copyrights protection by using binding regulations when such a protection doesn't entitle. The juxtaposition of legal regulations concerning to citing right and copyright trolling phenomenon leads to explanation how first of them can be use by copyright trolls. In this context it is absolutely necessary to analyze: threats for unrestrained functioning citing right in practice, the problem how to use it according to law and how to stand against copyright trolls forcefully.
\end{abstract}

Keywords: copyright trolling, citing right, legal use of somebody's else creation, abuse of copyright, copyright protection, copyright trolling control, stopping activity of copyright trolls

* Mgr, Uniwersytet Gdański. 


\section{Wprowadzenie}

Artykuł 29 ustawy z dnia 4 lutego 1994 r. o prawie autorskim i prawach pokrewnych [dalej: u.p.a.p.p.] ${ }^{1}$ ustanawia instytucję nazywaną prawem cytatu. Wskazana regulacja zawiera zezwolenie na nieodpłatne posłużenie się fragmentami lub całością utworu innego twórcy, jak również wskazuje cele, dla których taki użytek jest dozwolony. Może to być w szczególności: wyjaśnienie, polemika, analiza, krytyczna lub naukowa, nauczanie lub prawo gatunku twórczości. Przedstawiono też warunki, jakie musi spełnić osoba korzystająca z czyjegoś utworu w ramach tej konstrukcji prawnej. Cytat musi być przede wszystkim rozpoznawalny i wyraźnie oznaczony w utworze, w którym został użyty.

Copyright trolling (trolling prawnoautorski) to zjawisko nowe, którego rozwój postępował stopniowo, wraz z ekspansją Internetu i jest ściśle z nim związane. Do tej pory nie posiada on swojej definicji legalnej w prawie polskim ani też nie doczekał się kompleksowej regulacji ustawowej. Polega na masowym wysyłaniu wezwań do zapłaty, w celu uzyskania przez dany podmiot ochrony prawnoautorskiej, przez wykorzystanie obowiązujących przepisów, w sytuacji, w której taka ochrona nie przysługuje. Wezwania kierowane sa zarówno do osób, które dopuściły się naruszeń, jak i do tych zupełnie przypadkowych, w celu uzyskania od nich konkretnych kwot pieniężnych z tytułu naruszenia autorskich praw majątkowych. Działania copyright trolla nakierowane sa na wykorzystanie niewiedzy adresatów wezwań i uzyskanie od nich odszkodowań za naruszenie bądź rzekome naruszenie praw autorskich do utworu, w drodze ugody pozasądowej, bez przeprowadzania procesu.

Celem artykułu jest, przez zestawienie i omówienie regulacji prawnych odnoszących się do prawa cytatu i zjawiska copyright trollingu, zasygnalizowanie, jak pierwsza z tych instytucji może zostać wykorzystana do prowadzenia działań charakterystycznych dla copyright trolli, a więc $\mathrm{w}$ zupełnie innym celu niż została stworzona. Z jednej strony bowiem u.p.a.p.p., wyjątkowo, po spełnieniu warunków wymienionych w art. 29, przewiduje możliwość nieodpłatnego posłużenia się cytatem $\mathrm{z}$ utworu innego autora, z drugiej zaś jako zasadę korzystania z cudzej twórczości ustanawia odpłatność. Niezbędna jest również analiza zagrożeń, jakie dla swobodnego funkcjonowania prawa cytatu niesie z soba copyright trolling. Szczególną uwagę należy poświęcić kwestii, jak zgodnie z prawem korzystać z dotychczasowego dorobku, a także, w przypadku zetknięcia

${ }^{1}$ Artykuł 29 ustawy z dnia 4 lutego 1994 r. o prawie autorskim i prawach pokrewnych. Tekst jedn. Dz.U. 2017, poz. 880. 
się z negatywnymi praktykami copyright trolli, jak tym działaniom skutecznie się przeciwstawiać. Warto zaproponować rozwiazania, które powinien wziąć pod uwagę polski ustawodawca przy pracach legislacyjnych nad unormowaniem praktyk, określanych mianem copyright trollingu.

\section{Istota prawa cytatu i jego prawne regulacje}

Słowo „cytat” w języku polskim to dosłowne przytoczenie w tekście fragmentu innego tekstu lub czyichś słów². Pochodzi ono z języka łacińskiego od słów citatio - citare. Citatio oznacza wezwanie, obwołanie, ogłoszenie, przytaczanie, cytowanie ${ }^{3}$, natomiast citare jest równoznaczne z poruszać, pobudzać, powołać (się), przytaczać ${ }^{4}$; już w starożytności termin ten tłumaczono jako powoływanie się na wcześniejszych autorów ${ }^{5}$. Cytat ma ogromne znaczenie praktyczne, nie tylko w twórczości artystycznej, w szczególności w dziedzinach takich, jak literatura, muzyka czy film, ale także w działalności dydaktycznej czy naukowej. Powoływanie się bowiem na cudzą twórczość stanowi istotę i sposób rozwoju wielu pól ludzkiej aktywności, a wyjątkowo ważne jest właśnie dla nauki. Jak głosi jeden z najczęściej przytaczanych w nauce prawa poglądów, „jakakolwiek działalność twórcza nie odbywa się "w próżni«, lecz wymaga korzystania z osiągnięć twórczych innych podmiotów" ${ }^{6}$. Brak możliwości korzystania z dotychczasowego dorobku twórców z różnych dziedzin uznać należałoby za poważne ograniczenie rozwoju ludzkiej myśli i działalności intelektualnej ${ }^{7}$, kompletnie pozbawione sensu, a w praktyce niemożliwe do wyegzekwowania.

${ }^{2}$ M. Szymczak: Stownik języka polskiego PWN. A-K. Warszawa 1999, s. 304; E. Sobol: Nowy słownik języka polskiego PWN. Warszawa 2002, s. 104; Internetowy stownik języka polskiego PWN, https://sjp.pwn.pl/szukaj/cytat.html [Data dostępu: 12 grudnia 2017 r.]; M. Bańko: Wielki stownik wyrazów obcych PWN. Warszawa 2011, s. 234.

3 J. Pieńkos: Stownik tacińsko-polski. Eacina w nauce i kulturze. Kraków 2001, s. 74; W. Kopaliński: Stownik wyrazów obcych $i$ zwrotów obcojęzycznych z almanachem. Warszawa 2000, s. 107.

${ }^{4}$ W. Kopaliński: Stownik wyrazów obcych..., s. 107.

${ }_{5}^{5}$ P. Ślęzak: Dozwolony użytek chronionych utworów. W: Ustawa o prawie autorskim i prawach pokrewnych. Komentarz. Red. P. Ślęzak. Warszawa 2017, s. 294.

${ }^{6}$ J. Preussner-Zamorska, J. Marcinkowska, E. Laskowska: Dozwolony użytek na gruncie obowiazujacego prawa autorskiego. W: „System Prawa Prywatnego”. T. 13: Prawo autorskie. Red. J. Barta. Warszawa 2017, s. 646.

${ }^{7}$ A. Wachowska: Cytat utworu audiowizualnego w świetle ustawy o prawie autorskim i prawach pokrewnych. „Zeszyty Naukowe Uniwersytetu Jagiellońskiego. Prace z Prawa Własności Intelektualnej” 2009, z. 104, s. 25-26. 
Prawo cytatu jest jedną z postaci dozwolonego użytku publicznego, unormowana $\mathrm{w}$ art. 29 u.p.a.p.p. W obecnym kształcie przepis ten obowiąuje od 20 listopada 2015 r., kiedy to weszła w życie ustawa z dnia 11 września 2015 r. o zmianie ustawy o prawie autorskim i prawach pokrewnych oraz ustawy o grach hazardowych ${ }^{8}$. Na mocy jej art. 1 pkt 11 znaczaco zmieniono dotychczasową treść art. 29 u.p.a.p.p., rozszerzając zakres jego zastosowania9. Poprzednie brzmienie nie uwzględniało możliwości cytowania w całości utworów plastycznych oraz fotograficznych, a także enumeratywnie wyliczało cele, dla których korzystanie z cudzego utworu było dozwolone. Obecnie zniesiono te ograniczenia, co podyktowane było koniecznościa dostosowania brzmienia polskich przepisów do postanowień dyrektywy 2001/29/WE Parlamentu Europejskiego i Rady z dnia 22 maja $2001 \mathrm{r}$. w sprawie harmonizacji niektórych aspektów praw autorskich i pokrewnych w społeczeństwie informacyjnym ${ }^{10}$. Jak wskazano w uzasadnieniu do projektu ustawy nowelizującej art. 29 u.p.a.p.p., zawierał on kilka ograniczeń, niewystępujących $\mathrm{w}$ treści art. 5 ust. 3 lit. d i k dyrektywy 2001/29/WE oraz zawężał dozwolony użytek, dopuszczony przez dyrektywę, ograniczając możliwość cytowania jedynie do urywków utworów i drobnych utworów w całości ${ }^{11}$. W aktualnym kształcie przepis stanowi, że wolno przytaczać w utworach stanowiących samoistna całość urywki rozpowszechnionych utworów oraz rozpowszechnione utwory plastyczne, utwory fotograficzne lub drobne utwory w całości, w zakresie uzasadnionym celami cytatu, takimi jak: wyjaśnianie, polemika, analiza krytyczna lub naukowa, nauczanie, lub prawami gatunku twórczości. Jak wynika z treści przepisu prawo cytatu dotyczy wyłącznie eksploatacji utworów, do których autorskie prawa majątkowe jeszcze nie wygasły, a jednym z jego głównych celów jest „osiagnięcie właściwej równowagi między prawem użytkowników utworu lub innego przedmiotu objętego ochroną do swobody wyrażania opinii a przysługującym autorom prawem zwielokrotniania"12.

8 Artykuł 1 pkt 11 ustawy z dnia 11 września 2015 r. o zmianie ustawy o prawie autorskim i prawach pokrewnych oraz ustawy o grach hazardowych. Dz.U. 2015, poz. 1639.

9 T. Król, M. Pigulski, W. Młynarska-Wełpa: Prawo autorskie. Zmiany w 2015 i 2016 roku. Warszawa 2015, s. 37; K. Gienas: Dozwolony użytek chronionych utworów. W: Ustawa o prawie autorskim i prawach pokrewnych. Komentarz. Red. E. Ferenc-Szydełko. Warszawa 2016, s. 306-307.

${ }_{10}$ Artykuł 5 ust. 3 lit. d, k dyrektywy 2001/29/WE Parlamentu Europejskiego i Rady z dnia 22 maja 2001 r. w sprawie harmonizacji niektórych aspektów praw autorskich i pokrewnych w społeczeństwie informacyjnym. Dz.Urz. UE L 167, 22.06.2001, s. 230.

${ }^{11}$ Uzasadnienie do rządowego projektu ustawy o zmianie ustawy o prawie autorskim i prawach pokrewnych oraz ustawy o grach hazardowych, http://www.sejm.gov.pl/Sejm7. nsf/druk.xsp?nr=3449 [Data dostępu: 14 grudnia 2017 r.].

${ }^{12}$ Wyrok Trybunału Sprawiedliwości UE z dnia 1 grudnia 2011 r., C-145/10, pkt 134, http://curia.europa.eu/juris/document/document.jsf;jsessionid=9ea7d0f130d5cbe 
Nazwa „prawo cytatu” została wypracowana przez doktrynę, a sam ustawodawca nie posługuje się tym terminem ${ }^{13}$. Stanowi ono jedno z podstawowych ograniczeń wyłącznego prawa autorskiego na rzecz dozwolonego użytku publicznego, tj. na rzecz wykorzystania cudzej twórczości w działalności naukowej, dydaktycznej, publicystycznej czy artystycznej. W sposób prawidłowy i legalny może być wykorzystane tylko w sytuacji, gdy łącznie zostały spełnione warunki jego zastosowania, wyartykułowane $\mathrm{w}$ przepisie. Zgodnie $\mathrm{z}$ brzmieniem art. 29 u.p.a.p.p., pierwszym z wymogów jest uprzednie rozpowszechnianie utworu. Nadto dzieło zawierajace cytat musi stanowić samodzielna całość, tzn. musi być utworem w rozumieniu przywołanej ustawy. Ogromna rolę odgrywa także rozmiar cytatu i cel, w jakim go użyto, oraz oznaczenie źródła, z jakiego pochodzi ${ }^{14}$.

Prawidłowe zrozumienie przesłanki wcześniejszego rozpowszechniania utworu cytowanego, jak również jej zastosowanie w praktyce nie powinno budzić większych watpliwości. Ustawodawca w art. 6 ust. 1 pkt 3 u.p.a.p.p. wyjaśnia, jak rozumie pojęcie „utwór rozpowszechniony”. Określa go jako ten, który za zezwoleniem twórcy został w jakikolwiek sposób udostępniony publicznie. Jak wynika więc z treści powyższego przepisu, kluczowe znaczenie do zakwalifikowania utworu jako rozpowszechnionego ma łączne spełnienie trzech przesłanek: publiczne udostępnienie utworu, które odbywa się za zezwoleniem twórcy i dokonane jest w dowolny sposób ${ }^{15}$.

Kolejny warunek ustanowiony $\mathrm{w}$ art. 29, pozwalający na legalne wykorzystanie cudzego utworu $\mathrm{w}$ ramach instytucji prawa cytatu, to wymóg, aby dzieło cytujące stanowiło samoistną i samodzielną całość. Utwór, w którym wykorzystuje się cudzy dorobek, musi być oryginalny i stanowić twórczy wkład w rozwój swojej dziedziny, niezależnie od wykorzystanych w nim elementów autorstwa innej osoby ${ }^{16}$. Cytat stanowić ma jedynie element wzbogacajacy treść dzieła oraz sprawić, że staje się ono ciekawsze, pełniejsze i bardziej urozmaicone w treści. Nie może on zastępować jego głównej substancji czy też stanowić jedynych wniosków bądź konkluzji z niego wynikających. Zadaniem cytatu jest bowiem odegranie roli pomocniczej, pozwalającej na dalszy rozwój danego rodzaju twórczości ${ }^{17}$.

8ba7363fb4fae86f89974560efed1.e34KaxiLc3eQc40LaxqMbN4PaNqLe0?text=\&docid $=115785 \&$ pageIndex $=0 \&$ doclang $=P L \&$ mode=lst\&dir $=\& o c c=$ first\&part $=1 \&$ cid $=188735$ [Data dostępu: 19 grudnia 2017 r.].
13 A. Wachowska: Cytat utworu..., s. 25.
${ }^{14}$ P. Ślęzak: Dozwolony użytek..., s. 294.
${ }^{15}$ L. Małek: Cytat w świetle prawa autorskiego. Warszawa 2011, s. 246.
${ }^{16}$ A. Wachowska: Cytat utworu..., s. 30.
${ }^{17}$ L. Małek: Cytat w świetle..., s. 239. 
Niezwykle istotnym elementem, mającym wpływ na wartość artystyczną lub naukową dzieła, będzie rozmiar cytatu wykorzystany przez autora. Jednakże ustawodawca $\mathrm{w}$ tym zakresie nie zawarł $\mathrm{w}$ przepisach żadnych wskazówek, jak również nie określił w wymierny, policzalny sposób, jaki rozmiar cytatu będzie prawidłowy w świetle art. 29 u.p.a.p.p. Należy zaznaczyć, że praktycznie niemożliwe jest stworzenie ogólnej reguły, określającej proporcje utworu cytującego i cytowanego. Pogląd taki, znajduje solidne oparcie w zasadach logiki i powszechnie funkcjonuje w nauce prawa ${ }^{18}$. Nie jest bowiem jasne, jak te proporcje miałyby zostać obliczone, a także, jaki miernik zawartości cytatu powinien zostać obrany. Z pewnościa próba przyjęcia za kryterium ilościowe procentów, czy też liczby wyrazów, wersów, taktów bądź klatek, nie jest rozwiązaniem wykonalnym w praktyce. Utwór cytowany do utworu cytującego musi zatem pozostać w takiej proporcji, aby odbiorca nie miał wątpliwości, że ma do czynienia z oryginalnym i nowym dziełem ${ }^{19}$, stanowiącym samodzielny wkład twórcy cytującego w daną dziedzinę ludzkiej aktywności. Warto podkreślić, że ustawodawca w omawianym przepisie odwołuje się jedynie do ogólnych pojęć, takich jak „drobny utwór” oraz „urywek utworu”. Terminy te tylko wtedy, gdy poddane zostaną intensywnej wykładni językowej, systemowej, logicznej oraz historycznej, stanowić będą wstęp do zrozumienia ogólnych reguł, odnoszących się do dozwolonego rozmiaru cytatu. Bardziej szczegółowe zasady musiały więc zostać dopracowane przez doktrynę i orzecznictwo ${ }^{20}$. Nie zmienia to jednak faktu, że każda sytuacja musi być oceniana indywidualnie, z uwzględnieniem całokształtu towarzyszących okoliczności, a także specyfiki dziedziny, do której się odnosi.

Pośrednim doprecyzowaniem wytycznych w zakresie rozmiaru cytatu jest wskazanie celu, w jakim został on wykorzystany. Przed wejściem w życie ustawy z dnia 11 września 2015 r. o zmianie ustawy o prawie autorskim i prawach pokrewnych oraz ustawy o grach hazardowych art. 29 u.p.a.p.p. w sposób enumeratywny wymieniał cele, jakim mogło służyć wykorzystanie cytatu. Obecnie polski ustawodawca, wzorując się na postanowieniach dyrektywy 2001/29/WE, wymienia je jedynie przykładowo, dopuszczając możliwość skorzystania z prawa cytatu również w innych okolicznościach, np. dla celów estetycznych bądź wykorzystując

${ }_{18}$ P. Ślęzak: Dozwolony użytek..., s. 297; K. Gienas: Dozwolony użytek..., s. 308.

19 J. Preussner-Zamorska, J. Marcinkowska, E. Laskowska: Dozwolony użytek..., s. 647.

${ }^{20}$ Wyrok Sądu Najwyższego z dnia 23 listopada 2004 r., I CK 232/04. OSNC 2005, nr 11, poz. 195; wyrok Naczelnego Sądu Administracyjnego z dnia 11 lipca 2008 r., I OSK 472/08. LEGALIS nr 139471; wyrok Naczelnego Sądu Administracyjnego z dnia 11 lipca 2008 r., I OSK 363/08. LEGALIS nr 139470; wyrok Wojewódzkiego Sądu Administracyjnego w Warszawie z dnia 4 czerwca 2007 r., I SA/Wa325/07. LEGALIS nr 94818. 
go jako motto ${ }^{21}$. Cytatem wolno zatem posłużyć się w celu wyjaśnienia, polemiki, analizy krytycznej lub naukowej, nauczania oraz ze względu na prawa gatunku twórczości.

Autor korzystajacy z cudzej twórczości zawsze zobowiązany jest do oznaczenia cytatu, jego autora, a także źródła. Reguła ta wynika z art. 34 u.p.a.p.p., a na podstawie art. 100 znajduje ona zastosowanie również do przedmiotów praw pokrewnych. W przepisie sformułowano wyraźne wymagania co do wskazania imienia i nazwiska twórcy. Natomiast ze stanowiska doktryny wynika, że podanie pseudonimu artystycznego również będzie spełniać warunek prawidłowego oznaczenia autora $^{22}$. Zgodnie z postanowieniami art. 5 ust. 3 lit. a dyrektywy 2001/29/ WE, nazwisko twórcy zawsze powinno zostać przytoczone w pełnym brzmieniu, natomiast przy wskazywaniu imienia wystarczajace wydaje się podanie pierwszej jego litery ${ }^{23}$. Z pewnością nie będzie błędem, gdy imię wskazane zostanie w pełnym brzmieniu. Jeżeli zaś chodzi o wymienienie źródła, to przesłanka ta nie powinna budzić większych wątpliwości, choć prawodawca nie określił tego precyzyjnie w ustawie. Należy przez to rozumieć, w zależności od rodzaju dzieła cytowanego, oznaczenie autora, tytułu publikacji, tytułu publikatora (dziennik, czasopismo, strona internetowa), nazwy wydawcy, miejsca wystawienia, a w dziełach zbiorowych - nazwiska redaktora, wydawcy, producenta oraz miejsca i roku wydania ${ }^{24}$. Brak wskazania autora lub źródła bądź też mylne ich oznaczenie lub brak takiego oznaczenia z pewnością w znaczny sposób naruszają prawa twórcy, a także wykluczają legalne, prawidłowe skorzystanie $\mathrm{z}$ prawa cytatu ${ }^{25}$.

W świetle powyższych uwag oraz biorąc pod uwagę istotę i znaczenie prawa cytatu, oczywista wydaje się niemożność i niecelowość ustanowienia prawnego zakazu przytaczania cudzych utworów, zarówno w przepisach rangi ustawowej, jak i w drodze postanowień umownych. Takie klauzule, wprowadzane czasami w kontraktach przez autorów, bądź wydawców, jednostronnym oświadczeniem woli, sa z prawnego punktu widzenia po prostu nieskuteczne ${ }^{26}$.

${ }^{21}$ Uzasadnienie do rządowego projektu ustawy o zmianie ustawy o prawie autorskim i prawach pokrewnych z dnia 22.05.2015 r. Druk sejmowy nr 3449, http://www.sejm.gov. pl/Sejm7.nsf/druk.xsp?nr=3449 [Data dostępu: 28 grudnia 2017 r.].

${ }_{22}$ S. Stanisławska-Kloc: Treść prawa autorskiego. W: Prawo autorskie i prawa pokrewne. Red. D. Flisak. Warszawa 2015, s. 573.

${ }_{23}$ P. Ślęzak: Dozwolony użytek..., s. 330.

24 J. Barta, R. Markiewicz: Prawo autorskie. Warszawa 2016, s. 215-217; E. Traple: Treść prawa autorskiego. W: Prawo autorskie i prawa pokrewne. Komentarz. Red. J. Barta, R. Markiewicz. Warszawa 2011, s. 287-289.

${ }^{25}$ M. Jankowska: Autor i prawo do autorstwa. Warszawa 2011, s. 431-432.

${ }^{26}$ S. Stanisławska-Kloc: Treść prawa autorskiego..., s. 448. 
Z kolei analizując problem pod względem opcji wprowadzenia ujednoliconych i sztywnych zasad korzystania z prawa cytatu, takie rozwiąznie nie wydaje się możliwe do zastosowania w praktyce. Zawsze bowiem konieczne będzie pozostawienie pewnej swobody interpretacyjnej w tym zakresie, w szczególności z uwagi na różnorodność dziedzin, w których cytat może zostać wykorzystany.

Podsumowujac rozważania na temat tego, czym jest prawo cytatu i jak funkcjonuje w prawnej rzeczywistości naszego kraju, należy zaznaczyć, że normujacy je art. 29 u.p.a.p.p. nie może być interpretowany w sposób rozszerzający, z zastrzeżeniem art. 35 u.p.a.p.p. ${ }^{27}$ Ustawa o prawie autorskim i prawach pokrewnych z jednej strony, wyjątkowo, po spełnieniu warunków wymienionych w jej przepisach, przewiduje możliwość nieodpłatnego posłużenia się cudzym utworem (tzw. dozwolony użytek), w tym posłużenie się nim w ramach prawa cytatu, z drugiej zaś jako zasadę korzystania z cudzego utworu ustanawia odpłatnośćc ${ }^{28}$. Szczególną uwagę należy zatem poświęcić kwestii, jak zgodnie z prawem korzystać z prawa cytatu, aby nie rodziło to negatywnych konsekwencji natury prawnej i jednocześnie nie stanowiło przeszkody czy wręcz hamulca dla rozwoju nauki, czy którejkolwiek z dziedzin sztuki.

\section{Copyright trolling — ramy prawne}

Copyright trolling narodził się $\mathrm{w}$ Stanach Zjednoczonych Ameryki Północnej na przełomie XX i XXI w. W Polsce jest to zjawisko stosunkowo nowe. Pierwsze polskie publikacje na ten temat zaczęły pojawiać się około 2011 r. $^{29}$ i od tego czasu tematyka ta stale gości na łamach różnych tytułów, w dużej części internetowych. Jeżeli chodzi o dorobek polskiej literatury naukowej w przedmiocie trollingu prawnoautorskiego, określanego również angielskim terminem copyright trolling, to jest on niewielki ${ }^{30}$. Problematyka ta dopiero zyskuje u nas na znaczeniu,

${ }_{27}$ R. Markiewicz: Kilka uwag o dozwolonym użytku w prawie autorskim. „Zeszyty Naukowe Uniwersytetu Jagiellońskiego. Prace z Prawa Własności Intelektualnej” 2015, z. 128 , s. $14-16$.

${ }^{28}$ E. Ferenc-Szydełko: Treść prawa autorskiego. W: Ustawa o prawie autorskim i prawach pokrewnych. Komentarz. Red. E. Ferenc-Szydełko..., s. 194.

${ }^{29}$ Dziennik Internautów, http://di.com.pl/tagi/copyright_trolling [Data dostępu: 19 grudnia 2017 r.].

${ }^{30}$ O. Wrzeszcz: Trolling prawnoautorski (,copyright trolling”). „Zeszyty Naukowe Uniwersytetu Jagiellońskiego. Prace z Prawa Własności Intelektualnej” 2016, z. 134, s. 49 . 
w związku z dynamicznym rozwojem Internetu, a także dokonujacym się na naszych oczach postępem technologicznym ${ }^{31}$. Naturalna tego konsekwencją jest fakt, że zjawiskom tym towarzysza zarówno pozytywne, jak i negatywne aspekty funkcjonowania globalnej sieci w naszym życiu. $\mathrm{Za}$ jeden $\mathrm{z}$ aspektów negatywnych $\mathrm{z}$ pewnością uznać można trolling prawnoautorski. Nadmieniono już, że termin ten nie posiada swojej definicji legalnej. Jedyna, jaka pojawiła się w nauce prawa do tej pory, to definicja zaproponowana przez powstała w czerwcu 2014 r. inicjatywę Copyright Trolling Stop, zrzeszajaca osoby przeciwne nadużyciom prawników reprezentujacych dysponentów autorskich praw majątkowych ${ }^{32}$. Zgodnie z nia, zjawisko to polega na ,zastraszaniu ludzi poprzez żądanie od nich pieniędzy pod groźbą wszczęcia postępowania sądowego w oparciu o rzekome naruszenie przez nich praw autorskich. Istota tej działalności nie jest jednak dążenie do prowadzenia takich postępowań; jest ona bowiem obliczona na skłonienie zastraszonej osoby do zawarcia ugody"33. Zatem głównym celem działalności copyright trolla jest skłonienie jak największej liczby osób do zapłaty, pod pozorem ochrony autorskich praw majatkowych, nawet niewielkich kwot, tytułem zaspokojenia rzekomych roszczeń karnych i cywilnych.

Należy również wspomnieć o szerokiej definicji copyright trollingu, zaproponowanej przez autora licznych publikacji na ten temat Marcina Maja na łamach „Dziennika Internautów”, w 2015 r. Zgodnie z jej brzmieniem, jest to „wykorzystanie prawa autorskiego w sposób „złośliwy" i przesadny, obliczony bardziej na osiągnięcie korzyści majątkowej niż na faktyczną ochronę praw autora lub wydawcy"34.

Swoja definicję, opierając się na wspomnianej wcześniej, choć jednocześnie nieco ją modyfikujacc, zaproponowała także Olga Wrzeszcz, autorka pierwszej pracy magisterskiej w Polsce poświęconej trollingowi praw-

${ }^{31}$ R. Markiewicz: Internet i prawo autorskie - wykaz problemów i propozycje ich rozwiazań. „Zeszyty Naukowe Uniwersytetu Jagiellońskiego. Prace z Prawa Własności Intelektualnej” 2013, z. 121, s. 18.

32 E. Laskowska: Konstrukcja ochrony prawnoautorskiej na tle procesu europeizacji prawa prywatnego. Warszawa 2016, s. 325-328; K. Ceglarska-Piłat, M. Zbrojewska: Komentarz do art. 80 ustawy Prawo o adwokaturze. W: Prawo o adwokaturze. Komentarz. Red. P. Kruszyński. Warszawa 2016, s. 214.

${ }^{33}$ List inicjatywy Copyright Trolling Stop i popierajacych ja organizacji do Prezesa Naczelnej Rady Adwokackiej, https://centrumcyfrowe.pl/wp-content/uploads/2014/ 07/234858798-List-Otwarty-Do-NRA.pdf [Data dostępu: 19 grudnia 2017 r.]; N. Mileszyk: Copyright trolling — skala zjawiska i propozycje rozwiazań, https://centrumcyfro we.pl/blog/2016/03/10/copyright-trolling-skala-zjawiska-i-propozycje-rozwiazan/ [Data dostępu: 19 grudnia 2017 r.].

${ }^{34}$ M. Maj: Czym właściwie jest „copyright trolling”?, http://di.com.pl/czym-wlasci wie-jest-copyright-trolling-52730 [Data dostępu: 19 grudnia 2017 r.]. 
noautorskiemu. Definiuje ona „trolling prawnoautorski” jako „działania uprawnionych lub potencjalnie uprawnionych do dysponowania majatkowymi prawami autorskimi, polegajace na zastraszaniu, stosowaniu szantażu lub innych form nacisku, w celu uzyskania korzyści majątkowych z tytułu zawartej ugody od osoby potencjalnie dokonujacej naruszenia majątkowych praw autorskich w Internecie" ${ }^{35}$. Nietrudno dostrzec, że $\mathrm{w}$ przedmiotowej definicji autorka uwzględniła jeden, bardzo istotny, element, którego zabrakło $\mathrm{w}$ propozycjach inicjatywy Copyright Trolling Stop. Wyraźnie wskazała, że działania charakterystyczne dla trolli moga prowadzić zarówno osoby nieuprawnione, jak i uprawnione z tytułu autorskich praw majątkowych. $\mathrm{Z}$ tego też względu dokonała umownego podziału na trolling prawnoautorski pośredni i bezpośredni. Trolling prawnoautorski pośredni to sytuacja, gdy podmiot uprawniony dochodzi roszczeń od naruszyciela majatkowych praw autorskich. Natomiast trolling prawnoautorski bezpośredni obejmuje przypadki, w których podmiot uprawniony dochodzi roszczeń od osoby, która nie dopuściła się żadnego naruszenia, gdy podmiot nieuprawniony dochodzi roszczeń od naruszyciela majątkowych praw autorskich, oraz gdy podmiot nieuprawniony dochodzi roszczeń od osoby, która nie dopuściła się żadnego naruszenia ${ }^{36}$.

$\mathrm{Z}$ prawnego punktu widzenia copyright trolling stanowi swoiste połączenie elementów wielu gałęzi prawa ${ }^{37}$, często, przynajmniej z pozoru, $\mathrm{w}$ żaden sposób z sobą tematycznie niepowiązanych. Zawiera $\mathrm{w}$ sobie pierwiastki m.in.: prawa autorskiego, prawa cywilnego, prawa karnego oraz polubownego rozstrzygania sporów, a także zagadnienia z zakresu ochrony konsumentów czy też ochrony danych osobowych. To właśnie ten hybrydowy charakter może utrudniać szybką i zdecydowaną reakcję na destrukcyjne działania trolli. Powoduje bowiem konieczność poszukiwania i wyinterpretowania stosownych rozwiązań z wielu aktów normatywnych odnoszących się do różnych gałęzi prawa, których regulacje bywają niespójne. $\mathrm{Z}$ pewnością skuteczne przeciwdziałanie copyright trollingowi wymaga czasu oraz wszechstronnej wiedzy prawniczej. Zetknięcie się z takimi praktykami uświadamia nam także, że polskie prawo dopiero wypracowuje środki, które pomoga w zwalczaniu tego zjawiska.

Autorskie prawa majątkowe, które maja uzyskać ochronę przez działania copyright trolli, bardzo często przysługuja zupełnie innemu podmiotowi niż ten, który na ich ochronę się powołuje. Nierzadkie są także sytuacje, gdy troll nachalnie wzywa do zapłaty za naruszenie praw autorskich, które nigdy nie miało miejsca. Z pewnością nie taki jest cel

\footnotetext{
${ }^{35}$ O. Wrzeszcz: Trolling prawnoautorski..., s. 49.

${ }^{36}$ Ibidem, s. $49-68$.

37 Ibidem, s. 38.
} 
objęcia ustawową ochroną autorskich praw majątkowych do utworów. Celem przedmiotowej ustawy jest w szczególności zapewnienie prawidłowego funkcjonowania rynku prawnoautorskiego na obszarze Rzeczypospolitej Polskiej. Chodzi o ochronę autora i jego twórczości przed nieuprawnionym wykorzystywaniem dorobku. Tymczasem copyright troll przez swoje praktyki nie dąży do zapewnienia ochrony praw twórcy, a jedynie do wzbogacenia się w wyniku zastraszenia odbiorców wezwań, wykorzystania ich nieznajomości prawa, wstydu ${ }^{38}$ czy pokusy definitywnego załatwienia sprawy przez zapłatę niskiej kwoty pieniężnej ${ }^{39}$.

Zjawisko copyright trollingu polega nie tylko na wykorzystywaniu prawa w sposób sprzeczny z jego celem i przeznaczeniem. Jest ono również nadużywaniem bądź wykorzystywaniem prawa przysługującego danemu podmiotowi w sposób nieadekwatny, nieetyczny czy nie do końca przystajacy do reguł funkcjonujacych w danym społeczeństwie. Analizując jego istotę, konieczne jest odwołanie się do treści art. 5 ustawy - Kodeks cywilny [dalej: k.c.] ${ }^{40}$, który dotyczy właśnie sprzeczności zachowania podmiotu uprawnionego z zasadami współżycia społecznego lub społeczno-gospodarczym przeznaczeniem prawa. Mimo że zachowanie to mieści się $\mathrm{w}$ treści stosunku prawnego $\mathrm{i}$ jest zgodne $\mathrm{z}$ istniejącym, w ramach prawa podmiotowego, uprawnieniem, z uwagi na wyjątkowe okoliczności zostaje z mocy prawa uznane za niedozwolone ${ }^{41}$. Na podstawie tej konstrukcji korzystanie przez uprawnionego z przysługującego mu prawa i egzekwowanie związanych z nim uprawnień, przy użyciu metod typowych dla trolli prawnoautorskich, nie powinno podlegać ochronie ${ }^{42}$. Jeżeli istnieje

${ }^{38}$ M. Maj: Pierwsi ukarani prawnicy - antypiraci, http://di.com.pl/pierwsi-uka rani-prawnicy-antypiraci-38487 [Data dostępu: 28 grudnia 2017 r.]; Idem: Prawnicy nie powinni dostać danych użytkowników RedTube, https://wolnemedia.net/prawnicynie-powinni-dostac-danych-uzytkownikow-redtube/ [Data dostępu: 28 grudnia 2017 r.]; W. Wawrzak: „Copyright troll”: kto to taki?, https://prakreacja.pl/copyright-troll [Data dostępu: 28 grudnia 2017 r.]; Jaworzno PL: Sprawa pism rozsyłanych rzekomo $w$ imieniu serwisu Pornhub, https://web.facebook.com/jaworznoPL/photos/a.158930 857629937.1073741827.158642520992104/789104434612573/?type=3\&theater [Data dostępu: 29 grudnia 2017 r.].

${ }^{39}$ M. Maj: Antypiraci wytudzali, zarobili tysiace, przejedli miliony, http://di.com. pl/antypiraci-wyludzali-zarobili-tysiace-przejedli-miliony-49679 [Data dostępu: 28 grudnia 2017 r.]; oficjalna strona Rightscorp Inc. https://www.rightscorp.com/ [Data dostępu: 28 grudnia 2017 r.].

40 Artykuł 5 ustawy z dnia 23 kwietnia 1964 r. — Kodeks cywilny. Tekst jedn. Dz.U. 2017, poz. 459 z późn. zm.

${ }^{41}$ M. Gutowski: Nadużycie prawa podmiotowego. W: Kodeks cywilny. T. 1: Komentarz. Art. 1-352. Red. M. Gutowski. Warszawa 2018, s. 70; P. Machnikowski: Konsekwencje nadużycia prawa. W: Kodeks cywilny. Komentarz. Red. E. Gniewek, P. Machnikowski. Warszawa 2017, s. 21-22.

${ }^{42}$ O. Wrzeszcz: Trolling prawnoautorski..., s. $55-57$. 
podejrzenie, że mamy do czynienia z działalnością copyright trolla, wzywajacego do zapłaty w przypadku rzeczywistego naruszenia praw autorskich, to powinno się szczegółowo zbadać, czy uprawniony nie korzysta ze swoich praw w sposób sprzeczny z zasadami współżycia społecznego bąź $\mathrm{z}$ jego społeczno-gospodarczym przeznaczeniem. Oczywiście, w przypadku faktycznego naruszenia autorskich praw majątkowych nie można kwestionować ratio legis przysługującej twórcy ochrony, wynikającej z przepisów ustawy o prawie autorskim i prawach pokrewnych. Problemem będzie tu jednak sposób, w jaki trolle prawnoautorskie takiej ochrony chca dochodzić i jakie stosuja ku temu środki. To właśnie analiza tych okoliczności będzie mieć decydujący wpływ na to, czy korzystanie z prawa następuje w sposób sprzeczny z zasadami określonymi w art. 5 k.c., a w konsekwencji, czy podlega ono ochronie, przewidzianej w przepisach prawa. Masowe rozsyłanie pism, nierzadko do przypadkowych osób, w których zawarto żądanie zapłaty określonej kwoty oraz groźbę wszczęcia postępowania karnego lub cywilnego przeciwko ich adresatom, w sytuacji niezawarcia ugody, świadczyć może, że intencją wysyłającego wezwanie nie jest ochrona praw autorskich, a jedynie wymuszenie zapłaty określonej sumy pieniężnej. Wypracowanie ostatecznego rozstrzygnięcia tego rodzaju sytuacji będzie każdorazowo wymagało ingerencji sądu przy rozważeniu wszystkich towarzyszaccych okoliczności, a przede wszystkim zamiaru, jakim kierował się wzywajacy do zawarcia ugody i zapłaty.

Element prawa karnego, przewijający się w działaniach trolli prawnoautorskich, polega często na powoływaniu się w przesyłanych pismach na toczące się postępowanie karne, niekoniecznie dotyczące adresata. Często przywoływane sa także przepisy karne z ustawy o prawie autorskim i prawach pokrewnych, które stanowić maja podstawę dochodzonych roszczeń i uzasadnienie żądania zapłaty wskazanych w wezwaniach kwot. Takie działanie bez watpienia ma na celu zastraszenie odbiorcy wezwania i przyspieszenie jego decyzji o zapłacie. Należy też nadmienić, że wiele copyright trolli w swojej działalności nie waha się bezpodstawnie wszczynać postępowań karnych jedynie w celu uzyskania danych osobowych, niezbędnych do kontynuowania procederu.

Wysyłanie wezwania do zapłaty przy dochodzeniu jakichkolwiek roszczeń jest zwykle uważane za pierwszy etap dążenia do wyegzekwowania potencjalnej należności. Jest to jednak zabieg podjęty poza sądem, a więc niejako otwierający droge do przeprowadzenia przez strony negocjacji w sprawie. W przypadku wezwania wystosowanego przez copyright trolla cel takiego pisma jest zupełnie inny. Ma ono służyć wymuszeniu zapłaty wskazanej kwoty, bazując na obawie adresata przed poważniejszymi konsekwencjami finansowymi i wszczęciem postępowania karnego. Celem trolla prawnoautorskiego jest bowiem szybki zysk, a nie dopro- 
wadzenie do stanu zgodności z prawem i ochrony uprawnionego czy też zapobieganie dalszym naruszeniom praw autorskich.

Wielokrotnie praktyki copyright trolli prowadziły adresatów pism bądź korespondencji mailowej do ujawnienia ich danych osobowych. Stąd można wysnuć wniosek, że działania te doprowadziły wiele osób do ujawnienia tych danych bez podstawy prawnej i wbrew ich woli. Copyright trolle wielokrotnie wszczynały też postępowania karne w celu ustalenia, na podstawie adresów IP, pozyskanych w nieustalony bliżej sposób danych osobowych, pod pretekstem naruszenia przez te osoby autorskich praw majątkowych, powołując się na art. 116 u.p.a.p.p. ${ }^{43} \mathrm{Z}$ dużym prawdopodobieństwem, graniczącym z pewnościa, zaryzykować można nawet twierdzenie, że czyniły to wyłącznie bądź głównie w celu ustalenia danych jak największej liczby osób. Niepokojaccy jest fakt, że późniejsze przetwarzanie przez trolle ustalonych w ten sposób danych nie podlega żadnej kontroli. Ryzyko, że wykorzystywane sa one do kontynuowania przez trolle prawnoautorskie ich działalności bądź używane są $\mathrm{w}$ inny niezgodny z prawem sposób jest niestety wysokie. Co prawda Generalny Inspektor Ochrony Danych Osobowych już na początku 2014 r. wyraził krytyczne stanowisko wobec takich praktyk, lecz jednocześnie dał jasno do zrozumienia, że rozwiąanie problemu nie będzie proste ${ }^{44}$. Do tej pory nie podjął on żadnych bardziej stanowczych kroków w celu objęcia przedmiotowego procederu kontrola ${ }^{45}$.

W rozważaniach dotyczacych multidyscyplinarnego charakteru zjawiska copyright trollingu nie sposób pominąć faktu, że wiąże się on także z pozycją i prawami konsumenta. Każdy z nas może otrzymać nieprzyjemne pismo, zawierajace groźbę wszczęcia postępowania sądowego, mimo że nie naruszył niczyich praw ani nie popełnił żadnego czynu zabronionego. Przedmiotowe wezwania trolli prawnoautorskich często kierowane sa do przypadkowych odbiorców - osób niezorientowanych w realiach gospodarczych, nieznających przepisów prawa i niebędących przedsiębiorcami, a więc nieposiadających przymiotu profesjonalisty. Taki odbiorca wezwa-

${ }^{43}$ P. Wipler: Interpelacja $n r 30707$ do Ministra Sprawiedliwości w sprawie instrumentalnego wykorzystania przepisów prawa w procederze tzw. copyright trollingu, http:// sejm.gov.pl/Sejm7.nsf/InterpelacjaTresc.xsp?key=799E0E76\&view=null [Data dostępu: 28 grudnia 2017 r.].

${ }_{44}$ M. Maj: Jest polski organ, który widzi wady copyright trollingu, http://di.com.pl/ jest-polski-organ-ktory-widzi-wady-copyright-trollingu-49378 [Data dostępu: 29 grudnia 2017 r.].

${ }^{45}$ M. Z brojew ska: Odpowiedź na interpelację $\mathrm{nr} 30707 \mathrm{w}$ sprawie instrumentalnego wykorzystania przepisów prawa w procederze tzw. copyright trollingu $\mathrm{z}$ dnia 3.03.2015 r., http://sejm.gov.pl/Sejm7.nsf/InterpelacjaTresc.xsp?key=7556DD07 [Data dostępu: 29 grudnia 2017 r.]. 
nia wystosowanego przez copyright trolla w świetle art. $22^{1} \mathrm{k} . \mathrm{c}^{46}$ bez wątpienia jest konsumentem, gdyż posiada wszystkie jego cechy, wymienione w tym przepisie. W związku z tym, że działania trolli w coraz większym zakresie dotyczą takich właśnie podmiotów, Urząd Ochrony Konkurencji i Konsumentów zainteresował się działalnościa jednego z nich - Lex Superior, który wysłał prawie 50 tys. wezwań ${ }^{47}$. Urząd wszczął przeciwko spółce postępowanie wyjaśniajace, które na dzień powstania tego artykułu jeszcze nie zostało zakończone. Nie wiadomo zatem, jakie będą wyniki tych działań i czy doprowadzą do jakichkolwiek zmian w istotny sposób poprawiajacych sytuację konsumentów.

Kolejnym istotnym i bardzo niepokojącym aspektem zjawiska trollingu prawnoautorskiego w Polsce jest udział w tym procederze radców prawnych i adwokatów, a więc osób wykonujących zawody zaufania publicznego. Osoby te co prawda nie sa trollami prawnoautorskimi, jednak odgrywają rolę ich pełnomocników i w ten sposób czynnie wspierają ich praktyki. Tymczasem od osób wykonujących te zawody wymagane są szczególnie wysokie kwalifikacje moralne, a każda z tych profesji posiada swój kodeks etyki, którym winni się kierować wszyscy jej przedstawiciele ${ }^{48}$. Tym bardziej jako wysoce naganne należy ocenić takie postępowanie profesjonalnych pełnomocników. Przeciwko kilku najbardziej aktywnym wszczęte zostały postępowania dyscyplinarne ${ }^{49}$. Sprawy te sa obecnie w toku.

Reasumując dywagacje na temat, czym jest copyright trolling, można wypunktować jego podstawowe cechy, pozwalajace zidentyfikować to zjawisko w sytuacji bezpośredniego zetknięcia się z nim. Jest on z pewnościa zjawiskiem złożonym, które od momentu pojawienia się w Polsce w miarę upływu lat ewoluuje i przybiera coraz bardziej natarczywy charakter.

${ }^{46}$ O. Wrzeszcz: Trolling prawnoautorski..., s. 70.

${ }^{47}$ K. Włodkowska: „Lex superior”, porno w sieci. Zarzuty UOKiK dla właścicieli spótki, http://trojmiasto.wyborcza.pl/trojmiasto/7,35612,21416308,weekend-lex-superior-porno-w-sieci-zarzuty-uokik-dla-wlascicieli.html [Data dostępu: 29 grudnia 2017 r.]; M. Lewczuk: „Lex Superior” wysyła wezwania do zapłaty do 50000 użytkowników, https://bezprawnik.pl/lex-superior-wezwanie-do-zaplaty-torrent-pornografia/ [Data dostępu: 29 grudnia 2017 r.].

${ }^{48}$ Kodeks etyki adwokackiej, http://www.nra.pl/dokumenty/Kodeks_Etyki_Adwokackiej_tekst_jednolity.pdf [Data dostępu: 29 grudnia 2017 r.]; Kodeks etyki radcy prawnego, http://kirp.pl/etyka-i-wykonywanie-zawodu/etyka/kodeks-etyki-radcy-prawnego/ [Data dostępu: 29 grudnia 2017 r.].

${ }^{49}$ M. Maj: „Copyright trolling” — raport, s. 4-5, https://prawokultury.pl/media/en try/attach/MMaj-CopyrightTrolling-raport.pdf [Data dostępu: 29 grudnia 2017 r.]; Id e m: „Lex Superior”: Wszczęto dochodzenie o przewinienie dyscyplinarne ws. radcy Magdaleny B., http://di.com.pl/lex-superior-wszczeto-dochodzenie-o-przewinienie-dyscyplinarne-wsradcy-magdaleny-b-53664 [Data dostępu: 29 grudnia 2017 r.]. 


\section{Prawo cytatu jako źródło copyright trollingu Korzystanie z prawa cytatu w świetle zagrożeń ze strony copyright trolli}

Po krótkiej charakterystyce prawa cytatu oraz przybliżeniu problematyki copyright trollingu nasuwa się pytanie, jakie aspekty dotyczace dozwolonego użytku publicznego w zakresie art. 29 u.p.a.p.p. moga spowodować, że stanie się on inspiracją dla działań trolli prawnoautorskich. Częściowo zagrożenia te zostały już zasygnalizowane, jednak warto poświęcić im nieco więcej miejsca. W ramach przedmiotowej regulacji jako podstawowe pole do nadużyć dla trolli można wskazać:

- nieostre, niedookreślone terminy użyte w treści art. 29, takie jak „urywki utworu” oraz „drobne utwory”,

- brak określenia dopuszczalnej wielkości cytatu,

- przykładowy charakter wyliczenia celów dopuszczalnego wykorzystania cytatu.

W odniesieniu do zasygnalizowanych zagadnień trzeba podkreślić, że nie zostały one wyliczone w sposób wyczerpujący. Wskazano jedynie najbardziej typowe potencjalne zagrożenia wykorzystania prawa cytatu przez copyright trolle. Trzeba pamiętać, że ich działalność jest w naszym kraju zjawiskiem stosunkowo nowym, a w polskim prawie brak regulacji normujących bezpośrednio tę problematykę. Nadto, zjawisko to ma charakter dynamiczny, metody działania trolli cały czas sa doskonalone, a także pojawiają się nowe sposoby nadużywania ochrony prawnoautorskiej. Dlatego też nawet krótka analiza możliwości wykorzystania prawa cytatu w takiej działalności może być pomocna w zwalczaniu copyright trolli.

Sposób redakcji art. 29 u.p.a.p.p., z uwagi na umieszczenie w nim pojęć niedookreślonych, powoduje, że każdorazowo zakres jego zastosowania wymagać będzie szczegółowej interpretacji w kontekście konkretnego stanu faktycznego. Granica bowiem pomiędzy dozwolonym użyciem cudzej twórczości a naruszeniem majątkowych praw autorskich nie została wytyczona za pomoca sztywnych, policzalnych kryteriów. Stwarzać to może podłoże do wykorzystania lub nawet nadużycia prawa cytatu przez internetowe trolle prawnoautorskie przez powoływanie się na fakt, że dany twórca skorzystał z cudzego dorobku bez tytułu prawnego, a nie w ramach dopuszczalnego użytku publicznego (prawa cytatu). W takiej sytuacji niezbędne jest doprecyzowanie znaczenia budzaccych watpliwości interpretacyjne terminów. Kluczowe będzie ustalenie rozumienia 
tych pojęć w języku, którym posługujemy się w życiu codziennym. Zwrot „urywek utworu” w języku polskim rozumiany jest jako krótki fragment jakiegoś tekstu lub muzyki bądź fragment jakiejś wypowiedzi, niedający obrazu całości ${ }^{50}$, a także jako kawałek czegoś, ustęp, wyjątek (zwłaszcza jakiegoś tekstu) ${ }^{51}$. W nauce prawa przyjęto, że ustawodawca używa w art. 29 u.p.a.p.p. terminu ,urywek” w potocznym tego słowa znacze$n{ }^{52}$. Dlatego też pojęcie to powinniśmy rozumieć jako krótki fragment utworu stanowiącego większą całość. Z kolei w odniesieniu do zwrotu „drobny utwór” ustawodawca nie wskazuje na podstawie jakich kryteriów można odróżnić je od utworów większych. Kierując się doświadczeniem życiowym oraz zasadami logiki, jako „drobny” należałoby określić utwór niezbyt długi, którego objętość pozwala na to, aby stał się częścią większej całości, wzbogacając i rozbudowujac ja, jednocześnie nie stanowiąc jej podstawowej treści. Z pewnością będzie też istotne, w jakiej proporcji pozostanie cytowany drobny utwór lub urywek utworu do utworu cytującego oraz czy zawartość tego pierwszego wybija się na pierwszy plan, czy jednak pozostaje na nim twórczość autora nowo powstajacego dzieła. Te niuanse interpretacyjne moga zostać wykorzystane przez trolle prawnoautorskie. Każda bowiem sytuacja graniczna, nawet uzasadnionego powołania się na dłuższy fragment cudzej twórczości bądź wykorzystania utworu, którego zakwalifikowanie jako drobny nie jest oczywiste, może powodować eskalację ich działań.

Kolejnym polem do nadużyć dla trolli prawnoautorskich może być brak określenia w art. 29 u.p.a.p.p. wielkości dopuszczalnego, a więc zgodnego z prawem, cytatu. Chodzi tu nie tyle o rozmiar przytaczanej w dziele zawartości, ile o stosunek wielkości cytatu do cytowanego utwo$\mathrm{ru}$, a także o pełnioną w nim funkcję. Należy bezwzględnie pamiętać, że cytat ma odgrywać rolę podrzędną i akcesoryjną w nowo powstajacym dziele. Gdy ten warunek nie zostanie spełniony, będziemy mieć do czynienia z powielaniem cudzego dorobku, a nie tworzeniem własnego, wzbogaconego jedynie wcześniejszymi dokonaniami innych twórców. Do problemu tego odniósł się już wcześniej Sąd Najwyższy w uzasadnieniu wspomnianego już wyroku z dnia 23 listopada 2004 r., stwierdzając, że „cytowany urywek lub nawet cały drobny utwór musi pozostawać w takiej proporcji do wkładu własnej twórczości, aby nie było watpliwości co do tego, że powstało własne, samoistne dzieło".

Oprócz ogólnych wskazówek określających rozmiar cytatu, wynikajacych $\mathrm{z}$ orzecznictwa oraz wypracowanych przez doktrynę, nie znajdziemy

${ }^{50}$ Internetowy stownik języka polskiego PWN, https://sjp.pwn.pl/szukaj/urywek.html [Data dostępu: 29.12.2017 r.].

${ }^{51}$ E. Sobol: Nowy stownik..., s. 1091.

52 P. Ślęzak: Dozwolony użytek..., s. 295. 
nigdzie, w tym także w obowiązujących regulacjach, żadnych dokładniejszych wytycznych w tym zakresie. W związku z tym, aby uzyskać całkowitą pewność, że rozmiar cytatu nie wykracza poza ramy prawne zakreślone $\mathrm{w}$ przepisach, dany stan faktyczny musi zostać poddany ocenie sąu powszechnego. Przeszkodą dla takiej ostatecznej weryfikacji może być fakt, że nie każdy chce zdecydować się na proces i konfrontację przed obliczem trzeciej władzy. Stąd właśnie obawa, że prawo cytatu może być wykorzystywane przez trolle prawnoautorskie do nękania i zastraszania twórców.

Wyliczone w art. 29 u.p.a.p.p. cele, dla jakich cytat może być wykorzystany, to kolejne potencjalne pole dla działalności trolli. Do momentu nowelizacji treści tego przepisu ustawa z dnia 11 września 2015 r. o zmianie ustawy o prawie autorskim i prawach pokrewnych oraz ustawy o grach hazardowych były one wymienione enumeratywnie. W znacznym zakresie limitowało to możliwość korzystania przez twórców z prawa cytatu i stanowiło niepotrzebną przeszkodę w korzystaniu z dorobku poprzedników. W obecnym stanie prawnym katalog celów jest katalogiem otwartym, niemniej nietrudno wyobrazić sobie sytuację, w której trolle, wykorzystując niewiedzę adresatów swoich pism, wskazuja, że nastąpiło naruszenie autorskich praw majatkowych, gdyż nie dotrzymano warunków użycia prawa cytatu przez wykorzystanie go w celu niewyartykułowanym w ustawie.

\section{Wnioski}

Rekapitulujacc powyższe rozważania, na podstawie obecnego stanu prawnego w pełni uzasadnione będzie sformułowanie wniosku, że prawo cytatu i korzystanie z niego moga stanowić inspirację dla działań copyright trolli. Zgodnie $\mathrm{z}$ art. 29 u.p.a.p.p., zagrożenie to nie może być jednak hamulcem swobodnego korzystania z posługiwania się dozwolonym użytkiem. Odwoływanie się bowiem do wcześniejszego dorobku w różnych dziedzinach jest naturalnym elementem pracy naukowej. Nie ma więc powodu, aby przez praktyki trolli prawnoautorskich twórcy, pracownicy naukowi i wszyscy, którzy w swojej aktywności wykorzystuja prawo cytatu, mieli ograniczona tę możliwość rozwoju. Jednak, w ocenie autorki, aby zwiększyć pewność prawa nie tylko w zakresie korzystania z prawa cytatu, konieczne będzie podjęcie działań zapobiegawczych i zwalczających copyright trolling na dwóch płaszczyznach.

Pierwsza z nich to starania na poziomie ustawodawcy, polegające na przygotowaniu i uchwaleniu stosownych aktów legislacyjnych normuja- 
cych tę problematykę. Aktywność prawodawcy może tu prowadzić zarówno do uchwalenia przepisów, mających na celu zapobieganie zjawisku copyright trollingu, a więc przepisów o charakterze prewencyjnym, jak i wprowadzenia do porzadku prawnego regulacji zwalczających i wprost zakazujacych podejmowania opisywanych działań ${ }^{53}$. Być może dobrym rozwiąaniem byłoby wypunktowanie w akcie prawnym rangi ustawowej podstawowych cech charakteryzujących tego rodzaju działalność, w celu ułatwienia jej identyfikacji. Takie rozwiązania musiałyby zostać wcześniej poddane dogłębnej analizie ekspertów co do ich skuteczności, ze względu na złożony charakter prawny copyright trollingu, w tym oczywiście w kontekście wykorzystywania prawa cytatu.

W związku z tym, że copyright trolling ewoluuje i rozwija się, obejmujacc swoim zakresem coraz to nowe obszary, nie będzie w pełni zasadna propozycja sformułowania jego definicji legalnej, gdyż w świetle tempa zachodzących zmian może ona okazać się bezużyteczna. Ustawodawca powinien jednak rozważyć wprowadzenie regulacji ustanawiajacych konkretne narzędzia do walki z tym zjawiskiem, takie jak chociażby stosowne sankcje karne. Jak bowiem wskazuje dotychczasowa praktyka, obecnie obowiązujące przepisy nie zapewniają wystarczającej ochrony bądź nie zapewniaja jej w ogóle. Podmioty, wobec których skierowane zostały działania trolli, a które nie skorzystały z pomocy profesjonalnych pełnomocników, bardzo często nieświadome swojej rzeczywistej sytuacji prawnej ulegały sugestiom zawartym w nierzetelnych wezwaniach.

Właśnie z tego względu, że w ostatnich latach szkodliwość zjawiska copyright trollingu jest coraz bardziej odczuwalna społecznie, naglacca staje się potrzeba wprowadzenia prawnych regulacji dedykowanych temu zjawisku.

Druga płaszczyzna działań antytrollingowych, jakie powinny zostać podjęte, to aktywność na poziomie podmiotów mogacych stać się ofiarami trolli lub podmiotów, które takimi ofiarami już się stały i szukają skutecznych rozwiązań swojej sytuacji. Kluczową rolę mogą odegrać tu kampanie informacyjne, a także inne szeroko pojęte działania edukacyjne, takie jak szkolenia i wspomaganie się wiedzą osób dobrze zorientowanych $\mathrm{w}$ przedmiotowej materii. W kontekście powyższych rozważań duże znaczenie dla uniknięcia negatywnych skutków działalności trolli prawnoautorskich będzie mieć też znajomość legalnych uwarunkowań

${ }^{53}$ J. Warzecha, B. Rzońca: Interpelacja nr 28559 do ministra kultury i dziedzictwa narodowego $w$ sprawie tzw. copyright trollingu, http://www.sejm.gov.pl/sejm7.nsf/ InterpelacjaTresc.xsp?key=53362CA8 [Data dostępu: 29 grudnia 2017 r.]; Stanowisko Centrum Cyfrowego $w$ sprawie ram prawnych $w$ zakresie egzekwowania praw własności intelektualnej, https://centrumcyfrowe.pl/wp-content/uploads/2016/03/stanowisko-Cen trum-Cyfrowego-w-sprawie-IPRED_29.02.2016.pdf [Data dostępu: 30 grudnia 2017 r.]. 
prawidłowego posługiwania się prawem cytatu. Pozwoli ona na korzystanie z niego bez ryzyka narażenia się na zarzut naruszenia prawa autorskiego i nachalne ataki copyright trolli.

Ponieważ poczynania copyright trolli bazują w dużej mierze na obawie przed wszczęciem postępowania karnego czy przed konsekwencjami finansowymi, w walce $\mathrm{z}$ tym zjawiskiem istotne jest, aby nie dać się zastraszyć i nie działać bez zapoznania się z całokształtem okoliczności sprawy. W przypadku otrzymania wezwania z pewnościa jednym z pierwszych posunięć powinno być zidentyfikowanie nadawcy, a także ustalenie, czy rzeczywiście przysługują mu autorskie prawa majatkowe, o których mowa w otrzymanym piśmie. Spokojna i rzeczowa analiza zarzutów wynikajacych z przesłanego wezwania oraz weryfikacja wskazanych tam faktów pozwolą ocenić jego prawdziwość oraz zasadność. Niezbędne jest także dokładne ustalenie, w jaki sposób adresat wezwania korzystał z prawa cytatu, a nierzadko, czy w ogóle z niego skorzystał. Zdarza się bowiem, że pisma z roszczeniami kierowane są do osób przypadkowych, które nigdy nie dokonały żadnych naruszeń autorskich praw majątkowych. Istotne jest też sprawdzenie, czy pełnomocnik, który wysłał do nas pismo, jest skutecznie umocowany i czy to umocowanie pochodzi rzeczywiście od podmiotu, który jest właścicielem autorskich praw majątkowych do konkretnego dzieła, oraz czy jego zakres na pewno odpowiada istocie sprawy.

Dotychczasowe doświadczenia z copyright trollami dowodzą, że będą one próbowały za wszelka cenę uniknać konfrontacji przed sacdem. Postępowanie sądowe pozwala przecież na dokonanie niezbędnych ustaleń i prawnej oceny stanu faktycznego przez kompetentny organ. Obnaży więc intencje, jakimi kieruje się copyright troll, a także brak prawnego umocowania dla jego żądań. Podpisanie ugody, w dodatku w kształcie przez niego proponowanym, nie da nam gwarancji, że zaspokajamy słuszne roszczenie, oraz że jej zawarcie definitywnie zakończy nieprzyjemną sprawę. Zwłaszcza, że takie porozumienie często bywa dopiero początkiem zgłaszanych przez trolle roszczeń. Warto upowszechniać tę wiedzę nie tylko wśród twórców i pracowników naukowych korzystajacych w swojej pracy z prawa cytatu. Z pewnościa zwiększenie świadomości prawnej w tym zakresie przyczyni się do zmniejszenia skali zjawiska trollingu prawnautorskiego.

Kończąc powyższe rozważania, należy stwierdzić, że nie budzi żadnych wattpliwości coraz pilniejsza potrzeba wprowadzenia do polskiego prawa regulacji antytrollowych. W tej dziedzinie naszego życia litera prawa zdecydowanie nie nadąża za szybko zmieniającą się rzeczywistościa. Niestety, do tej pory polski prawodawca, mimo wielu niepokojących sygnałów regularnie pojawiających się od kilku lat, nie dostrzegł takiej konieczności. 



\section{Materiały}

\section{Jubileusz 50-lecia pracy naukowej Profesora dr. hab. Andrzeja Mączyńskiego Sprawozdanie z konferencji naukowej nt. Prawo prywatne międzynarodowe wobec wyzwań XXI wieku, Kraków, 14 maja 2018 roku}

W dniu 14 maja 2018 r. w auli głównej Polskiej Akademii Umiejętności w Krakowie, jednej z najstarszych polskich instytucji naukowych, odbyła się sesja naukowa nt. Prawo prywatne międzynarodowe wobec wyzwań XXI wieku, która towarzyszyła uroczystości jubileuszu 50-lecia pracy naukowej Pana prof. dr. hab. Andrzeja Mączyńskiego, obecnie wiceprezesa PAU. Organizatorami uroczystości i sesji byli Polska Akademia Umiejętności oraz Wydział Prawa i Administracji Uniwersytetu Jagiellońskiego w Krakowie.

Na wstępie Prezes PAU prof. dr hab. Andrzej Białas przywitał Jubilata wraz z małżonką Anną oraz rodzina. Następnie prezes PAU powitał przybyłych szacownych gości, wśród których znaleźli się byli rektorzy UJ oraz obecny rektor Uniwersytetu Pedagogicznego w Krakowie, prorektor Uniwersytetu Gdańskiego, prorektor Uniwersytetu Jagiellońskiego, rektor Krakowskiej Akademii im. A. Frycza Modrzewskiego, wybitni przedstawiciele środowiska prawniczego, w tym byli prezesi i byli wiceprezesi oraz byli sędziowie Trybunału Konstytucyjnego, byli Rzecznicy Praw Obywatelskich, przedstawiciele: sadownictwa (w tym prezes i były prezes Izby Cywilnej SN), Państwowej Komisji Wyborczej, notariatu, palestry, były i obecny sekretarz PAU, oraz pozostałych gości już niewymienianych przez niego z nazwiska w związku z pełnioną funkcją. Mimo wstępnej 
zapowiedzi powitania jednymi oklaskami wszystkich gości, z ogromnym aplauzem przyjęto pierwszą damę prawa - pierwszą osobę sprawujacą urząd Rzecznika Praw Obywatelskich, byłego sędziego TK - Panią prof. dr hab. Ewę Łętowską.

Następnie gości, którzy do ostatniego miejsca wypełnili aulę PAU, powitał JM Rektor Uniwersytetu Jagiellońskiego prof. dr hab. Wojciech Nowak. Pogratulował on Jubilatowi pięćdziesięciu lat pracy w Alma Mater i złożył serdeczne życzenia na przyszłość.

Dziekan Wydziału Prawa i Administracji UJ prof. dr Jerzy Pisuliński w krótkiej mowie okolicznościowej podziękował Profesorowi A. Mączyńskiemu, byłemu prodziekanowi Wydziału oraz wieloletniemu kierownikowi Katedry Prawa Prywatnego Międzynarodowego (był inicjatorem jej utworzenia), za lata pracy, pogratulował wspaniałego dorobku naukowego oraz złożył życzenia pomyślności na przyszłość.

Główne przemówienie okolicznościowe wygłosił prof. dr hab. dr. hc. Marek Safjan, obecnie sędzia Trybunału Sprawiedliwości UE, prezes Trybunału Konstytucyjnego z okresu, gdy Jubilat pełnił w nim funkcję wiceprezesa. Panowie profesorowie w latach 2001-2006 wspólnie kierowali pracami Trybunału Konstytucyjnego. Profesor M. Safjan znamiennie, i jakże aktualnie, nie tylko z uwagi na Jubilata, zatytułował swoje wystąienie - O konstytucji $w$ ujęciu konstytucyjnie wrażliwego prawnika ${ }^{1}$.

Profesor M. Safjan rozpoczął od wskazania, że „perspektywa sędziego jest inna niż profesora prawa”, ale spojrzenie teoretyka i praktyka moga się spotkać i „stworzyć syntezę, która pozwala na dostrzeżenie wielu nowych aspektów niedostrzegalnych z osobna z perspektywy czy to sędziowskiej, czy to teoretycznej”. Jak wskazał, w przypadku Jubilata taka synteza nastapiła „na poziomie konstytucji, kiedy obserwacja ta dotyczy sędziego konstytucyjnego - zbieżność dwóch podejść praktyka i teoretyka może być szczególnie płodna”. Następnie profesor M. Safjan omówił cechy - pewne szczególne predyspozycje związane ze stosowaniem Konstytucji w sądzie konstytucyjnym, które charakteryzują Jubilata.

Przede wszystkim należą do nich ,widzenie całego systemu prawa jako całości, która jest podporządkowana określonemu porządkowi (hierarchii) wartości - poza zasadami gałęziowymi istnieją zasady nadrzędne wynikajace z konstytucji” oraz występujące pomiędzy nimi zależności. Jak wskazał, „A niestety - wiedza o tych zależnościach jest ciagle dość hermetyczna i słabo rozpowszechniona, nawet na poziomie

${ }^{1}$ Wszystkie cytaty pochodzą $\mathrm{z}$ tekstu wystąpienia profesora M. Safjana, udostępnionego na potrzeby przygotowania tego sprawozdania. Tekst ten zatytułowany $O$ konstytucji $w$ ujęciu konstytucyjnie wrażliwego prawnika ukazał się, już po przygotowaniu niniejszego sprawozdania, w „Przeglądzie Konstytucyjnym” 2018, nr 4, s. $107-123$. 
najwyższych instytucji sądowych, co można dostrzec dzisiaj w związku z postulatem bezpośredniego, rozproszonego stosowania kontroli konstytucyjności prawa". Profesor M. Safjan zwrócił uwagę na wyzwanie, jakim dzisiaj jest coraz bardziej skomplikowany proces poszukiwania znaczenia normy prawnej przy zastosowaniu całej gamy instrumentów wykładni prawa. Podkreślił, że „prawnik teoretyk, a zwłaszcza prawnik, który zajmuje się prawem międzynarodowym prywatnym, tak jak Andrzej Mączyński, jest zapewne lepiej niż ktokolwiek inny przystosowany do poszukiwania normy właściwej - rozumianej jako normy dekodowanej z całego, wielosegmentowego systemu prawa”. Przytoczył także przykłady orzeczeń Trybunału Konstytucyjnego, które „wymagały takiego wielopoziomowego "ćwiczenia" na normach", w których Jubilat jako sprawozdawca miał swój znaczacy udział (wyrok dotyczacy dziedziczenia gospodarstw rolnych z dnia 31 stycznia 2001 r., sprawa P 4/99; wyrok dotyczący obowiązku meldunkowego z dnia 27 maja 2002 r., sprawa K 20/01; wyrok na tle ustawy o spółdzielniach mieszkaniowych z dnia 20 kwietnia 2005 r., sprawa K 42/02).

Następną cechą według profesora M. Safjana jest „określony background historyczny, który umożliwia rozumienie korzeni poszczególnych instytucji, ich sensu i funkcji oraz kształtowania się w perspektywie historycznej”. Jak wskazał, nie osiagnnie się tego bez nauczania historii prawa oraz prawa rzymskiego, za czym zawsze opowiadał się Jubilat. Ten fragment wypowiedzi profesora M. Safjana zawierał liczne przykłady wydarzeń z historii, odwołanie do filozofii Kanta, pism Radbrucha czy przypomnienie negatywnych konsekwencji (o czym się zapomina) odejścia od teorii Monteskiusza. Nawiązał także do „wielkiej roli historycznej wybitnych osobistości nauki prawa”. Dalej mówił: „cenię sobie bardzo ową wrażliwość historyczna prof. Andrzeja Mączyńskiego, jego starania i dbałość o to, by rozwijać tę pamięć poprzez przypomnienie - także w ramach jego aktywności w Polskiej Akademii Umiejętności - o wybitnych autorytetach prawniczych". Należy dodać, że staraniem Jubilata od lat na łamach „Kwartalnika Prawa Prywatnego”, w rozbudowanych notach biograficznych, przypominane są kolejnym pokoleniom sylwetki wybitnych przedstawicieli świata prawniczego, twórców szkół prawniczych. Pan Profesor A. Maczyński jest redaktorem naczelnym „Kwartalnika Prawa Prywatnego", periodyku wydawanego przez PAU od 1992 r.

Kolejną cechą sędziego konstytucjonalisty, którą wyróżnił profesor M. Safjan, jest mistrzostwo słowa (języka); „wykładnia prawa, a zwłaszcza wykładnia na poziomie konstytucyjnym, wymaga subtelności i precyzji języka, wyobraźni i szerokiej perspektywy”. Profesor tak mówił, charakteryzując Jubilata: „dobrze rozumiał, że język uzasadnienia każdego rozstrzygnięcia sądowego musi wykładać racje uczciwie i transparentnie, 
a wymaganie jest tym większe, im bardziej jest kwestionowane czy też kontrowersyjne samo orzeczenie" (jako przykład podał wyrok w sprawie konstytucyjności odpowiedzialności karnej za zniesławienie - wyrok z dnia 30 października 2006 r., sprawa P10/06, w której panowie profesorowie mieli odmienne zdania). M. Safjan zwrócił uwagę na znakomite wyczucie Jubilata w zakresie budowy konstytucyjnych pojęć autonomicznych.

Zdaniem M. Safjana, cechą Jubilata jest także wrażliwość konstytucyjna. Wyjaśniając, czym jest owa cecha, profesor odniósł się do wywiadu² udzielonego przez Jubilata, w którym ten stwierdził: „Zoll (młodszy) był twórca koncepcji "prawa prawego«, stanowiącego ideał prawa, zbiór norm najbardziej odpowiednich dla danego czasu i miejsca. Dążenie do urzeczywistnienia tego ideału jest zadaniem każdego prawnika, zarówno tego, który ma wpływ na tworzenie prawa, jak i tego, który stosuje obowiązujace prawo. Zdolność odnajdywania "prawa prawego" Zoll nazywa poczuciem prawa”. Profesor M. Safjan przypomniał istotne zalecenie przywoływane w wywiadzie przez profesora A. Maczyńskiego, aby „prawnik kierował się w swej pracy jasnym umysłem i goracym sercem i zawsze miał przed oczyma cele, dla których istnieja instytucje prawne".

W końcowej części wystąpienia M. Safjan bezpośrednio odniósł się do sytuacji, mającej miejsce w Trybunale Konstytucyjnym od 2016 r., której jak się wydaje żaden, nie tylko wrażliwy konstytucyjnie, prawnik nie może zrozumieć i na nią przystać.

W dalszej części sesji głos zabrał dr hab. Piotr Mostowik, który wraz z prof. dr. hab. Kazimierzem Zawadą, w imieniu uczniów i współpracowników, przygotował do druku wybór rozpraw i studiów Jubilata. P. Mostowik, który jest uczniem profesora A. Mączyńskiego, nadając nieco lżejszy ton swojej wypowiedzi (nawiązując do list bestsellerów), krótko scharakteryzował tę wspaniała część dorobku Jubilata, która została przypomniana w okolicznościowej publikacji zatytułowanej Rozprawy i studia $z$ prawa prywatnego międzynarodowego, przygotowanej przez wydawnictwo Wolters Kluwer. Zbiór, który składa się z ponad 30 publikacji, z lat 1974-2016, ujętych w 6 częściach (I. Rozwój prawa prywatnego międzynarodowego; II. Zagadnienia kodyfikacyjne; III. Instytucje ogólne; IV. Prawo osobowe; V. Prawo rodzinne; VI. Prawo spadkowe), liczy prawie 900 stron. Wydaje się, że wybór ten (skonsultowany z A. Maczyńskim) w znacznej części odzwierciedla nie tylko główne Jego zainteresowania związane $\mathrm{z}$ prawem prywatnym międzynarodowym, lecz ukazuje też najważniejsze problemy, z jakimi ta gałaź prawa (ze swej natury „wielowatkowa”) musiała sobie poradzić w ostatnim półwieczu.

${ }^{2}$ Poczucie prawa - wywiad z prof. A. Maczyńskim. „Edukacja Prawnicza” 2001, nr 1 (37), s. $20-24$. 
Podkreślenia wymaga, że Jubilat miał swój znaczny i doniosły udział w ich rozwiązaniu. Nota bibliograficzna umieszczona w końcowej części zawiera całościowy wykaz prac z prawa prywatnego międzynarodowego autorstwa profesora A. Mączyńskiego. Dalszą charakterystykę dorobku zawartego w jubileuszowej publikacji przedstawił praktyk dr Maciej Tomaszewski. Zwrócił on uwagę na współczesne duże znaczenie rozpraw Jubilata, szczególne z uwagi na to, że stosunki społeczno-prawne na co dzień przekraczaja granice państw, a zagadnienia kolizyjnoprawne stanowia przedmiot prac w UE oraz w świecie.

Życzenia w imieniu uczniów złożyli dr Sybilla Stanisławska-Kloc (magistrantka Jubilata, obecnie zatrudniona w Katedrze Prawa Własności Intelektualnej WPiA UJ) oraz dr hab. Piotr Mostowik (doktorant Jubilata, obecnie zatrudniony w katedrze Prawa Prywatnego Międzynarodowego WPiA UJ).

$\mathrm{Na}$ zakończenie pierwszej części uroczystości głos zabrał sam Jubilat, który po podziękowaniu za przygotowanie wyboru pism i zorganizowanie konferencji podzielił się wspomnieniami z okresu studiów i pracy w Uniwersytecie Jagiellońskim. Podkreślił, jak wiele zawdzięcza swoim nauczycielom i mistrzom - profesorom Kazimierzowi Przybyłowskiemu, Józefowi Skąpskiemu i Henrykowi Trammerowi. Odniósł się też do współczesnego stanu prawa prywatnego międzynarodowego w Polsce i w Europie. Wspomniał również o doświadczeniach zdobytych podczas pracy w Radzie Legislacyjnej, Komisji Kodyfikacyjnej Prawa Cywilnego, Trybunale Konstytucyjnym i Państwowej Komisji Wyborczej. Swoje wystąpienie zakończył, cytując wiersz Adama Bieszka Bez Kilimandżaro z wydanego w 2011 r. tomu pt. Zanim. Wypowiedź tę zebrani przyjęli oklaskami i owacją na stojaco.

Druga część jubileuszu - połączona ze składaniem indywidualnych gratulacji i życzeń - odbyła się w auli małej PAU. Najpierw toast na cześć Jubilata wzniósł Prezes PAU profesor A. Białas. W imieniu uczniów prof. dr hab. Bogusława Gnela, pierwsza doktorantka Jubilata, wzniosła toast za pomyślność Pana Profesora i Jego małżonki - Pani Anny. Słowa podziękowania skierowano do Pani Anny za Jej nieocenione wsparcie i wyrozumiałość dla pasji naukowych męża i Jego zaangażowania w ważne sprawy państwowe. Poza oczywistymi przymiotami intelektu i niezwykła pracowitością Jubilata, to wsparcie małżonki i rodziny umożliwiły Mu zgromadzenie tak wielkiego dorobku i uzyskanie tak szerokiego uznania w kraju i zagranica.

Większość przybyłych około 200 osób, których nie sposób wymienić czy choćby wzmiankować, składała Jubilatowi indywidualnie gratulacje. Czyniły to osobistości świata prawniczego, rodzina, przyjaciele, współpracownicy, uczniowie. Chyba wielu osobom zapisała się w pamięci wypowiedź 
przedstawiciela Związku Polskich Artystów Plastyków, który dziękował profesorowi A. Mączyńskiemu za zaangażowanie w sprawy artystów, $\mathrm{w}$ tym pomoc $\mathrm{w}$ ustalaniu statusu prawnego pracowni plastycznych $\mathrm{w}$ prawie lokalowym, którego znawca jest Jubilat. Profesor A. Mączyński jest członkiem honorowym Związku Polskich Artystów Plastyków, a także Stowarzyszenia Urzędników Stanu Cywilnego oraz członkiem Association de la Bibliotheque Polonaise de Paris. W kuluarach goście prowadzili rozmowy dotyczace stanu prawa i praworządności w Polsce.

Następnie rozpoczęła się sesja naukowa nt. Prawo prywatne międzynarodowe wobec wyzwań XXI wieku, której moderatorem był prof. dr hab. Kazimierz Zawada z WPiA UJ, obecnie kierownik Katedry Prawa Prywatnego Międzynarodowego. Sesja składała się z trzech trzydziestominutowych wykładów. Jako pierwsza referat wygłosiła dr hab. prof. UJ Nina Półtorak, sędzia Sądu UE, która przed laty przygotowywała swoja prace magisterska pod kierunkiem Jubilata. Jak wspomniała, to Pan Profesor skierował jej myśli ku prawu europejskiemu — za co Mu podziękowała na wstępie. Profesor N. Półtorak zatytułowała swoje wystapienie Rola Unii Europejskiej w kształtowaniu wspótczesnego prawa prywatnego międzynarodowego. Drugim prelegentem był prof. dr hab. Karol Weitz z Uniwersytetu Warszawskiego, sędzia Sądu Najwyższego. Wygłosił on referat zatytułowany Europejskie wyzwania współczesnego prawa procesowego cywilnego państw członkowskich Unii Europejskiej. Kolejnym prelegentem był dr hab. Mateusz Pilich z Uniwersytetu Warszawskiego, który zaprezentował wykład nt. Prawo prywatne międzynarodowe wobec wyzwań wspótczesności: migracje i multicentryczność. Po wystąpieniach ${ }^{3}$ miała miejsce dyskusja, w której głos zabrali m.in.: prof. dr hab. A. Biernat, prof. dr hab. A. Rzepliński, prof. dr hab. A. Zachariasiewicz. Sesja była ważnym wydarzeniem dla prawniczego środowiska naukowego.

Drogiemu Jubilatowi Panu Profesorowi Andrzejowi Mączyńskiemu, który objął zaszczytną funkcję wiceprezesa Polskiej Akademii Umiejętności w kadencji 2018-2021, życzymy dalszych sukcesów w życiu osobistym i zawodowym — ad multos annos!

${ }^{3}$ Teksty prezentowanych podczas konferencji wystąień zostały opublikowane w „Kwartalniku Prawa Prywatnego”, zob.: N. Półtorak: Rola Unii Europejskiej $w$ kształtowaniu wspótczesnego prawa prywatnego międzynarodowego. „Kwartalnik Prawa Prywatnego" [dalej: KPP] 2019, z. 2, s. 297; K. Weitz: Wpływ prawa UE na krajowe prawo procesowe cywilne. KPP 2019, z. 2, s. 297; M. Pilich: Prawo prywatne międzynarodowe wobec wyzwań wspótczesności: migracje i multicentryczność. KPP 2019, z. 2 , s. $335-378$.

W imieniu organizatorów Jubileuszu i sesji Sybilla Stanistawska-Kloc 

Redakcja i korekta: Mariusz Jakosz, Barbara Todos-Burny

Projekt okładki: Grzegorz Nowak

Łamanie: Alicja Załęcka

ISSN 2353-9852

Czasopismno wcześniej ukazywało się w formie drukowanej

ISSN 1896-7604

Publikacja na licencji Creative Commons Uznanie autorstwa-Na tych samych warunkach 4.0 Międzynarodowe (CC BY-SA 4.0)

\section{(c) (1) ()}

Wersją pierwotna (referencyjna) czasopisma jest wersja elektroniczna, ukazująca się na platformie www.journals.us.edu.pl

W formie elektronicznej publikacja dostępna jest również $\mathrm{w}$ zasobach Central and Eastern European Online Library (www.ceeol.com)

Wydawca

Wydawnictwo Uniwersytetu Śląskiego

ul. Bankowa 12B, 40-007 Katowice

www.wydawnictwo.us.edu.pl

e-mail: wydawus@us.edu.pl

Wydanie I. Ark. druk. 9,5. Ark. wyd. 10,5. 


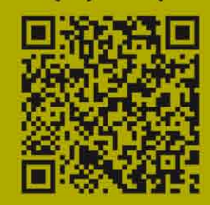

